Danilo Cymrot

A criminalização do funk sob a perspectiva da teoria crítica

Dissertação de Mestrado

Orientador: Professor Sérgio Salomão Shecaira

Faculdade de Direito da Universidade de São Paulo

São Paulo

2011 
Danilo Cymrot

\title{
A criminalização do funk sob a perspectiva da teoria crítica
}

\begin{abstract}
Dissertação apresentada à Banca Examinadora da Faculdade de Direito da Universidade de São Paulo, como exigência parcial para obtenção do título de Mestre (área de Concentração: Direito Penal, Medicina Forense e Criminologia).
\end{abstract}

Orientador: Professor Sérgio Salomão Shecaira

Faculdade de Direito da Universidade de São Paulo

São Paulo 
Danilo Cymrot

\section{A criminalização do funk sob a perspectiva da teoria crítica}

Data

Banca Examinadora

Orientador Professor Sérgio Salomão Shecaira

Prof.(a) Dr.(a):

Prof.(a) Dr.(a): 


\section{AGRADECIMENTOS}

Agradeço ao meu orientador, Sérgio Salomão Shecaira, pela cumplicidade e coragem em encarar este desafio comigo. Por possibilitar que eu trilhe os caminhos da interdisciplinaridade com serenidade. Pelo aprendizado em sala de aula, seja como meu professor, seja como meu supervisor. Pelo incentivo e pela confiança.

A Davi de Paiva Costa Tangerino, por suas valiosas contribuições na minha banca de qualificação, por se mostrar sempre interessado nos meus estudos e por todas as oportunidades que me proporcionou.

A Alamiro Velludo Salvador Netto, pelas preciosas observações no exame de qualificação e por acompanhar de perto minha trajetória há tanto tempo.

Ao Conselho Nacional de Desenvolvimento Científico e Tecnológico-CNPq, cujo auxílio foi imprescindível para que eu pudesse me dedicar à pesquisa.

Ao Grupo de Estudos de Temas de Criminologia-GETCrim, pelos ricos debates travados.

A Inês Virgínia Prado Soares, por apostar tanto em mim.

À minha família, que me incentivou e meu deu todo o suporte para e eu cursar este mestrado.

A todos os amigos que, de uma forma ou de outra, contribuíram para que esta dissertação fosse escrita.

Muito obrigado. 


\section{A criminalização do funk sob a perspectiva da teoria crítica}

\section{RESUMO}

O presente trabalho tem por objeto o estudo da criminalização do funk no Brasil, partindose da hipótese de que determinadas práticas culturais produzidas e/ou consumidas predominantemente por determinada parcela da população brasileira, isto é, a juventude pobre e negra, foram e são objeto de uma política penal, em detrimento de uma política cultural. Por meio da análise do funk, uma manifestação cultural que particularmente sofreu e sofre repressão penal, e aplicando-se os subsídios teóricos da criminologia, principalmente da teoria crítica, buscou-se compreender os mecanismos que legitimam e explicam o tratamento penal dessa manifestação, situá-lo em seu contexto histórico-social e questionar a hipótese de que, apesar do pretexto de se resguardar a ordem pública, a criminalização do funk se insere em uma lógica mais ampla de criminalização que se caracteriza pela seletividade e atinge uma determinada parcela da população. Foram empregados procedimentos de método de pesquisa histórico, sociológico e comparativo. As técnicas de pesquisa consistiram em consulta a fontes primárias (legislação, notícias de jornais e letras de música) e secundárias (pesquisa bibliográfica). Entre outros tópicos, foram abordados a forma como os arrastões suscitam a discussão sobre o lugar do pobre no espaço urbano; os atos de vandalismo e violência no contexto do lazer, à luz das contribuições da teoria da subcultura delinquente; a fabricação de pânicos morais pela mídia; as políticas de tolerância zero; a relação entre os traficantes de drogas, os artistas e o público do funk; a ascensão do gênero de funk "proibidão" e como se tornou, para alguns, o retrato da realidade e, para outros, o palco musical onde se desenrola o conflito entre as facções criminosas e onde se exalta a figura do "bandido romântico".

Palavras-chave: funk, controle social, arrastão, galeras, tráfico 


\section{La criminalizzazione del funk dal punto di vista della teoria critica}

\section{RIASSUNTO:}

Il presente lavoro ha come obiettivo lo studio della criminalizzazione del funk in Brasile, a partire dall'ipotesi che alcune pratiche culturali prodotte e/o consumati prevalentemente da certa parte della popolazione, cioè, poveri e dei giovani neri erano e sono oggetti di una politica criminale, piuttosto che una politica culturale. Attraverso l'analisi di funk, una manifestazione culturale particolarmente che hanno sofferto e che ancora soffrono di procedimenti penali, e applicando il supporto teorico di criminologia, in particolare la teoria critica, la ricerca ha cercato di comprendere i meccanismi che spiegano e legittimano il trattamento criminale di questa manifestazione, siccome situare nel suo contesto storico e sociale ed ancora questionare l'ipotesi che, nonostante il pretesto della tutela dell'ordine pubblico, la criminalizzazione del funk rientra in una logica più ampia di criminalizzazione che si caratterizza per la selettività che la fa raggiungere soltanto una certa porzione della popolazione. Le procedure metologiche impiegate sono state i metodi di ricerca storica, sociologica e comparata. Le tecniche di ricerca hanno consistito di consulenza a fonti primarie (legislazione, notizie storie e testi) e secondarie (letteratura). Tra gli altri argomenti discussi sono stati: come i "pescherecci da traino" (arrastão) aumentano il dibattito sul trattamento dei poveri nelle aree urbane; atti di vandalismo e di violenza nel contesto del tempo libero, alla luce dei contributi della teoria delle sottoculture delinquenziali; la produzione dei panici morali da media; le politiche di tolleranza a zero; il rapporto tra spacciatori di droga; gli artisti e il pubblico del funk; la nascita del genere del funk "proibidão" e come è diventato, per alcuni, il quadro della realtà, e per gli altri, il musical teatrale in cui il conflitto si svolge tra le bande e dove si esalta la figura del "delinquente romantic

Parole chiave: funk, controllo sociale, peschereccio, bande, il traffico 
Como entender as multidões se elas não falam, não pensam, não sabem e vivem da pura e irresponsável euforia numérica?

(Nelson Rodrigues, Flor de obsessão) 


\section{SUMÁRIO}

INTRODUÇÃO $\quad 10$

1. Uma história da repressão do funk 16

1.1. O fechamento dos bailes 16

$\begin{array}{ll}\text { 1.2. A legislação do funk } & 18\end{array}$

2. O arrastão 25

2.1. O caos chega à Zona Sul 25

2.2. Fabricando um arrastão 26

2.3. O lugar do pobre $\quad 31$

2.4. O cordão atuarial 35

2.5. Arrastões, espaço público e tolerância zero 40

2.6. Arrastões e subcultura do delinquente 43

2.7. A relação entre as galeras funk e as quadrilhas 48

2.8. Um bonde chamado terror: a subcultura da "zoação" 55

2.9. A contextualização histórico-política do arrastão e a criação de 61 pânicos morais pela mídia

2.10. O lado producente da violência $\quad 63$

3. O baile de corredor $\quad 67$

3.1. As características principais do baile de corredor 67

3.2. O papel das equipes de som: ascensão e decadência do baile de 70 corredor

3.3. O papel dos DJs $\quad 75$

3.4. O aspecto lúdico do baile de corredor $\quad 79$

$\begin{array}{lll}\text { 3.5. Os concursos de galeras } & 84\end{array}$

3.6. A afirmação do ethos de virilidade e a glamorização da 88 violência

3.7 O fechamento dos bailes $\quad 95$

4. Os bailes de Comunidade e o"proibidão" 100

4.1. O financiamento e a segurança dos bailes de comunidade 100

$\begin{array}{ll}\text { 4.2. Baile funk e drogas } & 104\end{array}$

4.3. As relações ambíguas entre "bandidos", MCs e "otários" 111

4.4. Retrato da realidade ou apologia? 116 
4.5. Por que os MCs cantam "proibidões"?

4.6. O bandido "Robin Hood" 132

4.7. Crime, literatura, música e cinema 140

4.8. A corrupção de menores $\quad 144$

4.9. O caso Tim Lopes 148

5. Criminologia crítica e criminalização do funk 154

5.1. A criminologia crítica 154

5.2. Moralismo e paternalismo penal 156

5.3. O componente subversivo da diversão 167

5.4. O medo da aglomeração negra 169

5.5. O componente racial na criminalização do funk 176

5.6. Seletividade e distância social 179

5.7. Os caras-pintadas da periferia: a criminalização da juventude 185

5.8. Neoliberalismo, funk e criminalização da pobreza 191

6. Conclusão 196

$\begin{array}{ll}\text { Bibliografia } & 198\end{array}$ 


\section{INTRODUÇÃO}

A grande mudança de paradigma na ciência criminológica, que até então se ocupava de estudar principalmente as causas da criminalidade (paradigma etiológico), foi antecipada parcialmente pela teoria do labelling approach, mas veio em definitivo somente com a criminologia crítica, que reflete sobre o próprio conceito de crime, o objeto e o papel da investigação criminológica. ${ }^{1}$ Trata-se de uma teoria materialista do desvio, dos comportamentos socialmente negativos e da criminalização.

A problematização é centrada precipuamente nas normas jurídicas e sociais, nos mecanismos de definição e reação sociais responsáveis pela construção da realidade social e não mais centrada nas causas do desvio. De acordo com os críticos ou radicais, o paradigma etiológico, referente à investigação das causas da criminalidade, só faz sentido se esta for entendida como uma entidade natural, ontológica, preexistente a qualquer tipo de definição e reação social e institucional. ${ }^{2}$

Não se pode considerar o legislador um ser iluminado, capaz de captar a essência de "crimes naturais" e cristalizá-la em tipos penais. O conceito jurídico-penal de crime é o de uma conduta típica, ilícita e culpável. O direito penal tem um caráter fragmentário, ou seja, não prevê em seus tipos penais todas as condutas socialmente negativas. Enquanto por um lado, muitas vezes valora como criminosas condutas cuja lesividade social é bastante questionável; por outro, deixa no terreno da atipicidade condutas cuja lesividade social é considerável. Na visão dos críticos, por trás de um discurso ideológico que oculta os conflitos sociais e naturaliza as escolhas dos tipos penais, estão decisões políticas de proteger certos interesses de classe, ou seja, são criminalizadas as condutas lesivas às classes dominantes e não criminalizadas as condutas lesivas praticadas por essas classes dominantes.

Conclui-se que o crime é um fenômeno construído a partir de uma definição, de um processo de criminalização. O que difere o criminoso do não criminoso não é uma patologia, mas apenas o estigma que lhe é atribuído pela reação social. Atos são criminosos porque é do interesse da classe dominante assim defini-los. Trata-se de uma decisão

\footnotetext{
${ }^{1}$ DIAS, Jorge Figueiredo; ANDRADE, Manuel da Costa. Criminologia: o homem delinquente e a sociedade criminógena. Coimbra: Editora Coimbra, 1992. p. 59.

${ }^{2}$ GOMES, Luiz Flávio; GARCÍA-PABLOS DE MOLINA, Antonio. Criminologia. 3. ed. São Paulo: RT, 2000. p. 568-569.
} 
política modificável, não um conceito operacional ${ }^{3}$, haja vista que condutas que já foram valoradas como criminosas, como o adultério, hoje não são mais. Como investigar as causas da criminalidade então, se, de acordo com Nils Christie, há uma oferta ilimitada de condutas passíveis de serem criminalizadas ${ }^{4}$

Sendo crime aquilo que é definido pela lei penal como crime, percebe-se que a criminalidade é um fenômeno distribuído por todas as classes sociais e, portanto, obra de uma maioria e não de uma minoria desviante ou anormal. Qualquer pessoa que tenha cometido alguma conduta tipificada pela lei penal, abstratamente poderia ser tida como criminosa. Contudo, apenas uma parte da população é alvo do sistema penal. A seletividade do sistema se expressa tanto no momento de eleição dos bens jurídicos tutelados penalmente (criminalização primária), quanto na perseguição dos indivíduos estigmatizados selecionados entre todos os indivíduos que infringem normas penalmente sancionadas (criminalização secundária). ${ }^{5}$

A criminologia crítica nega, desta forma, o mito do direito penal como direito igual. Além de o direito penal não defender todos e somente os bens essenciais, quando pune as ofensas o faz com intensidade desigual e de modo fragmentário, distribuindo o status de criminoso de modo desigual, independentemente da danosidade social das ações e da gravidade das infrações à lei. ${ }^{6}$ Refutou-se a ingênua justificação do caráter fragmentário do direito penal, baseada na natureza das coisas ou na idoneidade técnica de certas matérias, e não de outras, para ser objeto de controle penal. Demonstrou-se que a seletividade se dá não só na eleição dos bens jurídicos dignos de tutela penal, mas na própria formulação técnica dos tipos legais, que, quando se dirigem às classes subalternas, têm sua rede muito fina e bem articulada com o mecanismo das agravantes. ${ }^{7}$

Apesar de não haver um tipo penal que criminalize diretamente o funk ou o baile funk - talvez até porque a Constituição reserve ao Poder Legislativo Federal a competência exclusiva de legislar em matéria penal -, diplomas legislativos estaduais, embora tragam normas de direito administrativo, têm um caráter bastante repressor na medida em que colocam inúmeras exigências para que os bailes funk sejam realizados de forma lícita, chegando ao ponto de, na prática, tê-los inviabilizado. Além disso, é próprio do direito

\footnotetext{
${ }^{3}$ SHECAIRA, Sérgio Salomão. Criminologia. São Paulo: Revista dos Tribunais, 2004. p. 347.

${ }^{4}$ CHRISTIE, Nils. A indústria do controle do crime. Rio de Janeiro: Forense, 1998. p. 13.

${ }^{5}$ GOMES, Luiz Flávio; GARCÍA-PABLOS DE MOLINA, Antonio, op. cit. p. 362.

${ }^{6}$ BARATTA, Alessandro. Criminologia crítica e crítica do direito penal: introdução à sociologia do direito penal. Rio de Janeiro: Revan, 1997. p. 162.

${ }^{7}$ GOMES, Luiz Flávio; GARCÍA-PABLOS DE MOLINA, Antonio, op. cit. p. 133-134.
} 
administrativo e de normas penais em branco, como as que tutelam a "ordem pública" e a "paz pública”, deixar à autoridade policial uma grande margem de arbitrariedade, que neutraliza o princípio da legalidade e acentua ainda mais o caráter seletivo da criminalização secundária.

Não se pode esquecer que na essência de todos os sistemas disciplinares funciona um pequeno mecanismo penal com suas leis próprias, delitos especificados, formas particulares de sanção, instâncias de julgamento. As disciplinas estabelecem uma “infrapenalidade”, quadriculam um espaço deixado vazio pelas leis, tornam penalizáveis as frações mais tênues da conduta e dão uma função punitiva aos elementos aparentemente indiferentes do aparelho disciplinar. É passível de pena todo o campo indefinido do não conforme. ${ }^{8}$ Além da criminalização do funk ser permeada pela arbitrariedade policial, dá ensejo ao abuso de autoridade, conforme indica o seguinte Acórdão:

\begin{abstract}
0039445-16.2006.8.19.0000 (2006.059.06389) - HABEAS CORPUS DES. ELIZABETH GREGORY - Julgamento: 21/11/2006 - SETIMA CAMARA CRIMINAL

Pacientes denunciados por infração comportamental ao artigo $242, \S 2^{\circ}$, inciso II, com a agravante do artigo 70, II, letras g e 1, do Códig Penal Militar (roubo simples com concurso de agentes, com abuso de poder e estando em serviço), objetiva através do presente writ seja concedida sua liberdade provisória, ao argumento de ser primário, bons antecedentes, atividade laborativa regular, policiais militares que são, bem com residência fixa no distrito da culpa. $O$ decreto de prisão preventiva se baseia no fato de terem as vítimas se dirigido diretamente ao Comando do Batalhão de Policiamento em Vias Especiais, BPVE, e ali denunciado que foram roubados pelos ora pacientes, a quantia de R\$ 340,00, ao terem os mesmos parado seu veículo, utilitário de transporte coletivo, com 15 passageiros, em plena Av. Brasil, ao argumento de que estariam ouvindo música de apologia ao crime. Determinaram os pacientes que as vítimas os acompanhassem a Delegacia de Policia mais próxima para registro da ocorrência, sendo certo que no meio do caminho interromperam a trajetória subtraindo das vítimas e passageiros a quantia acima citada. Ressalte-se que foi encontrada com os pacientes a referida quantia, sendo certo que também foram reconhecidos pelas vítimas, quando afirmaram que os pacientes haviam anotado seus dados pessoais, com o intuito de coagi-los a não denunciar tal prática.
\end{abstract}

O presente trabalho tem por objeto o estudo da criminalização do funk no Brasil, partindo-se da hipótese de que determinadas práticas culturais produzidas e/ou consumidas predominantemente por determinada parcela da população brasileira, ou seja, a juventude pobre e negra, foram e são objeto de uma política penal em detrimento de uma política

\footnotetext{
${ }^{8}$ FOUCAULT, Michel. Vigiar e punir. 28 ed. Petrópolis: Editora Vozes, 2004. p. 90, 149-151. O poder policial deve-se exercer sobre tudo o que acontece, coisas de todo instante, coisas à-toa, toda desordem, agitação, desobediência (Ibid. p. 176-177). Cf. também RUSCHE, Georg; KIRCHHEIMER, Otto. Punição e estrutura social. 2.ed. Rio de Janeiro: Revan/Instituto Carioca de Criminologia, 2004. p. 214.
} 
cultural. Por meio da análise do funk, uma manifestação cultural que sofreu e sofre particular repressão penal, e da aplicação dos subsídios teóricos da criminologia, principalmente da teoria crítica, buscar-se-á compreender os mecanismos que legitimam e explicam o tratamento penal dessa manifestação, situá-lo em seu contexto histórico-social e questionar a hipótese de, apesar do pretexto de se resguardar a ordem pública, a criminalização do funk se inserir em uma lógica mais ampla de criminalização caracterizada pela seletividade e que atinge uma determinada parcela da população.

Por outro lado, deve-se levar em conta que a caracterização da criminalidade e do desvio apenas como resultados de um processo de definição provoca a ocultação de situações socialmente negativas e de sofrimentos reais, pontos de referência objetivos das definições. ${ }^{9}$ Por tal razão, este trabalho adotará também o ponto de vista dos chamados neo-realistas de esquerda. Estes defendem que as chamadas "causas do delito" devem ser denunciadas pela própria teoria crítica, seja para que a injustiça estrutural seja identificada em sua gênese, seja porque o delito enquanto problema real é um fenômeno intraclassista e não interclassista, ou seja, os desprovidos são os que mais sofrem com a criminalidade. ${ }^{10}$

Os neo-realistas de esquerda não negam, porém, a seletividade do sistema penal. "Se a universalidade [da criminalidade] tornou improváveis as noções positivistas convencionais de causalidade, a seletividade [do sistema de justiça criminal] apontou problemas fundamentais nas ideias neoclássicas de igualdade perante a lei”. ${ }^{11}$ Reconhecer que uma subcultura tem aspectos criminais e tentar compreendê-los não impede o reconhecimento de que algumas subculturas criminais são criminalizadas em detrimento de outras.

No levantamento bibliográfico preliminar deste trabalho foi verificado que há estudos sobre o funk nos campos da Sociologia, Música, Psicologia, História, Antropologia (ex: Hermano Vianna, Olívia Maria Gomes da Cunha, Fátima Cecchetto), Jornalismo (ex: Silvio Essinger), Educação, Comunicação (ex: Micael Herschmann) e até Direito.

\footnotetext{
${ }^{9}$ BARATTA, Alessandro. Criminologia crítica e crítica do direito penal: introdução à sociologia do direito penal. Rio de Janeiro: Revan, 1997. p. 211-212. É possível, sem dúvida, a afirmação de uma existência objetiva de situações ou ações socialmente negativas, que representam repressão de necessidades reais, da faculdade de existir e desenvolver a própria existência que os indivíduos possuem em função das capacidades de produção material e cultural, em uma sociedade dada. Porém, essa construção objetiva dos problemas sociais emancipatória deve ser resultado de uma comunicação livre do poder entre os portadores das necessidades e não, como as definições oficiais e de sentido comum, de uma comunicação ideológica, funcional para a reprodução das relações sociais e de poder existentes (Ibid.p. 218 et seq.).

${ }^{10}$ SHECAIRA, Sérgio Salomão. Criminologia. São Paulo: Revista dos Tribunais, 2004. p. 336.

${ }^{11}$ YOUNG, Jock. A sociedade excludente: exclusão social, criminalidade e diferença da modernidade recente. Rio de Janeiro: Revan, 2002. p. 71-72.
} 
Levando-se em consideração que uma das mais significativas formas de lazer da juventude pobre e negra foi e ainda é sistematicamente reprimida, a criminologia não poderia simplesmente ignorar um fenômeno de tamanhas proporções. Sendo o método da criminologia interdisciplinar, urge elaborar um estudo que congregue todos os conhecimentos citados acima e sistematize cientificamente a lógica dos mecanismos tradicionais de repressão penal e policial ao funk.

No primeiro capítulo, será feito um apanhado da história da repressão do funk no Rio de Janeiro. No segundo capítulo, será estudado como os arrastões de praia da década de 90 iniciaram o processo de criminalização do funk. Os atos de vandalismo e de “zoação" serão abordados à luz das contribuições da teoria da subcultura delinquente. Também serão objeto de discussão a fabricação de pânicos morais, a forma como a mídia se associa ao aparelho repressivo estatal e interfere em disputas eleitorais, o lugar do pobre no espaço urbano, as formas como a juventude ocupa a cidade e as reações intolerantes geradas, como as políticas de tolerância zero, a configuração de novos movimentos juvenis e a dimensão política que eles adquirem.

No capítulo 3, será tematizado o baile de corredor, sua história, suas principais características e consequências. Será abordada a questão da violência das brigas de galeras, o significado que a violência tem para a juventude pobre, as medidas adotadas para criar uma cultura de paz nos bailes e o papel que o DJ exerce nesse sentido. Serão diferenciadas as galeras e as gangues, acentuando seus aspectos subculturais, sua organização e seus valores.

No capítulo 4, será analisado o baile de comunidade, as acusações de que são financiados por traficantes e constituem espaços de consumo livre de drogas. Será abordada a relação entre os traficantes e as associações de moradores, a razão dos MCs cantarem o "proibidão", bem como de os traficantes irem armados aos bailes. Na perspectiva da teoria da anomia, a ética do bandido será contrastada com a ética do trabalhador. Por sua vez, o fascínio que os "proibidões" exercem sobre jovens da classe média será examinado na perspectiva da subcultura delinquente. O "proibidão" será comparado a outros gêneros musicais também acusados de fazer apologia ao crime, como o gangsta rap.

Será analisada a origem do "proibidão" e como se tornou, para alguns, o retrato da realidade e, para outros, o palco musical onde se desenrola o conflito entre as facções criminosas, suas versões da História e seus códigos de conduta. Um tópico será destinado à 
análise da figura do "bandido romântico" e de como ela é recorrente em diversas manifestações culturais. Será abordada a questão da corrupção de menores, do componente pornográfico do funk, o caso Tim Lopes e como este foi importante para criminalizar ainda mais o funk.

Por fim, no capítulo 5 serão considerados os aportes teóricos da criminologia crítica para a análise de como o processo de criminalização do funk se concatena com a criminalização da juventude pobre, negra e favelada brasileira e se insere em uma lógica muito similar à da repressão de outras manifestações culturais disfuncionais tanto política como economicamente. 


\section{UMA HISTÓRIA DA REPRESSÃO DO FUNK}

\subsection{O fechamento dos bailes}

O funk carioca é um estilo musical com batida bem marcada que se originou da combinação de funk norte-americano, hip hop, miami bass, electro e diversas outras influências, inclusive brasileiras, como o samba. Os funks que tocavam nos bailes eram todos instrumentais ou com letras em inglês. Apenas no fim da década de 80, o DJ Marlboro iniciou o processo de nacionalização do funk, produzindo MCs que passaram a cantar funks em português. ${ }^{12}$ Já entre esses primeiros funks com letras em português, alguns foram acusados de fazer apologia ao crime. ${ }^{13}$

De acordo com Silvio Essinger, as denúncias de ligação entre os MCs e o crime organizado do Rio de Janeiro começaram em 1995. Os MCs da Rocinha Junior \& Leonardo tiveram que depor em inquérito aberto pela Divisão de Proteção à Criança e ao Adolescente (DPCA). A letra de seu "Rap das Armas" listava uma série de armas, era introduzida pela onomatopeia "paraparapapá, que imitava o som de metralhadoras, e ganhou diversas versões feitas por MCs de outras comunidades.

Também tiveram que depor, na mesma época, os MCs Cidinho \& Doca, da Cidade de Deus, que supostamente pediam "paz, justiça e liberdade", o lema do Comando Vermelho, em uma versão do "Rap da diferença"; e os MCs William \& Duda, que participaram até da gravação de um álbum do cantor Lulu Santos e cantavam "nós somos Borel, nós somos CV" em uma suposta versão do "Rap do Borel". ${ }^{14}$ A dupla do Borel compunha canções pacificadoras e parecia zelar pela reputação de bons moços, mas foi caçada, durante uma ocupação do Exército no Borel. Os militares receberam a informação de que a dupla incitava a violência e o tráfico por meio de suas músicas. Os MCs foram

\footnotetext{
$12 \mathrm{O}$ termo MC vem do inglês "Master of Cerimony". Originalmente um mestre de cerimônias, que apresentava atrações nos bailes e animava o público, o termo foi adotado para designar os cantores de funk e hip hop. Sobre a história do funk e do baile funk, cf. VIANNA, Hermano. O mundo funk carioca. 2 ed. Rio de Janeiro: Zahar, 1988; ESSINGER, Silvio. Batidão: uma história do funk. Rio de Janeiro: Record, 2005.

13 Cf. ESSINGER, Silvio, op. cit. p. 89 et seq. Em 1991, no lançamento do CD Funk Brasil 3, no Maracanãzinho, um tumulto ganhou manchetes de jornais e a partir de 1992, começou-se a especular na mídia sobre possíveis ligações entre funkeiros e o Comando Vermelho ou o Terceiro Comando (MEDEIROS, Janaína. Funk carioca: crime ou cultura?: o som dá medo: e prazer. São Paulo: Editora Terceiro Nome, 2006. p. 19).

${ }^{14}$ ESSINGER, Silvio, op. cit. p. 236-237. O clipe do Rap das Armas concorreu ao VMB, prêmio anual da rede de televisão MTV (MACEDO, Suzana. DJ Marlboro na terra do funk- Bailes, bondes, galeras e MCs. Rio de Janeiro: Dantes Livraria e Editora, 2003. p. 91). A música voltou a fazer sucesso maior ainda nos anos 2000, na trilha sonora do filme "Tropa de Elite". Cf. MEDEIROS, Janaína, op. cit. p. 69-70.
} 
pessoalmente se apresentar no Comando Militar do Leste, para os devidos esclarecimentos. Afirmaram aos sargentos serem apenas artistas do funk e fizeram questão de cantar seus raps, "para que não houvesse nenhuma dúvida sobre nossas mensagens". 15

Em 1992, a polícia se preocupava com os arrastões praticados por "funkeiros" na saída dos bailes, descritos como uma "modalidade de assalto em que ladrões se lançam em bando sobre as vítimas, arrancando delas tudo o que vêem", bem como com a associação entre essas ações e as grandes organizações criminosas das favelas. $\mathrm{O}$ dono da equipe de som Furacão 2000, Rômulo Costa, convocou em abril daquele ano uma passeata de protesto contra a proibição dos bailes, marcada na Cinelândia. Em agosto, proibido pela polícia de realizar seu baile na Associação Atlética Vicente de Carvalho, ele fez a festa na rua. No mesmo mês, o Clube do Balanço, que reunia equipes de som, protestou contra a interdição de bailes pelo Estado-Maior de Segurança do Rio de Janeiro. ${ }^{16}$

Os jornais da época relatavam chacinas como a do Morro do Turano, envolvendo uma "briga de traficantes" na saída do baile funk local, sequestros na saída do baile do Chapéu-Mangueira (inclusive do filho do deputado estadual, defensor do funk, Albano Reis) e brigas violentas entre galeras em ônibus lotados, no retorno dos bailes ou da praia. $^{17}$ Toda essa onda de criminalização culminou, durante as Operações Rio I e II (1995/1996), com a interdição definitiva deste tipo de evento por decisão judicial. ${ }^{18}$

De acordo com Herschmann, o fator decisivo para a proibição, em 1995, do baile de comunidade mais famoso da cidade, o do Chapéu-Mangueira, frequentado por muitos jovens do "asfalto", não foi a "perturbação da ordem", os congestionamentos ou o barulho que incomodava a vizinhança, mas as "evidências" que sugeriam a proximidade do funk com o crime organizado, dentre as quais a apreensão pela polícia de músicas que faziam apologia ao crime, o livre consumo de drogas nos bailes e o fato de as associações de moradores nunca conseguirem provar plenamente quem eram os responsáveis pelo pagamento das equipes de som.

Benedita da Silva, candidata derrotada à prefeitura do Rio em 1992, futura governadora do Estado, senadora, ministra e moradora de uma casa em frente à quadra em que se realizava o baile no Chapéu-Mangueira, tentou impedir a operação policial que

\footnotetext{
${ }^{15}$ RESENDE, Juliana. Operação Rio. São Paulo: Editora Página Aberta, 1995. p. 203-204.

${ }^{16}$ ESSINGER, Silvio, op. cit. p. 123.

${ }^{17}$ HERSCHMANN, Micael. O funk e o hip hop invadem a cena. Rio de Janeiro: Editora UFRJ, 2000. p. 104; ESSINGER, Silvio, op. cit. p. 135.

${ }^{18}$ HERSCHMANN, Micael, op. cit. p. 127-128.
} 
fechou o baile da comunidade. ${ }^{19}$ No mesmo ano de 1995, organizou-se uma CPI municipal (resolução ${ }^{\circ}$ 127, de 1995) que visava investigar a suposta ligação do funk com o tráfico de drogas no Rio. Como não se conseguiu provar essa ligação, alguns políticos se mobilizaram para regulamentar os bailes e garantir essa forma de lazer dos jovens oriundos dos segmentos populares. ${ }^{20}$

\subsection{A legislação do funk}

A lei municipal 2.518/96, de autoria do vereador Antônio Pitanga (PT), por sinal marido de Benedita da Silva, foi a primeira iniciativa legislativa em todas as esferas federativas no sentido de regulamentar os bailes funk. Teve pareceres favoráveis de todas as Comissões e cinco de seus nove artigos vetados. A lei atribui ao Município, em seu artigo $2^{\circ}$, a competência para "garantir a realização dessa manifestação cultural de caráter popular, em cumprimento ao art. 346, inciso VII, da Lei Orgânica do Município do Rio de Janeiro". Já o artigo $4^{\circ}$ atribui "aos organizadores a adequação das instalações necessárias para a realização dos bailes sob sua responsabilidade, dentro dos parâmetros estabelecidos na legislação vigente". ${ }^{21}$

Em julho de 1997, a Divisão de Repressão a Entorpecentes abriu inquérito contra Zezinho, dono da equipe de som ZZ, por incitação ao tráfico e, possivelmente, corrupção de menores. ${ }^{22}$ No ano de 1999, muitos bailes foram interditados. Em maio, começou uma investigação do Ministério Público que iria levar, seis meses depois, à instauração de uma CPI estadual. No dia 13 de novembro, Zezinho foi preso em sua casa, onde foram apreendidas fitas que mostravam menores tirando a roupa nos bailes em troca de dinheiro, além de muitas brigas.

\footnotetext{
${ }^{19}$ Em junho de 1995, o baile do Chapéu Mangueira, frequentado por mais de cinco mil pessoas, foi interditado por causa de reclamações de moradores do Leme e Copacabana em relação ao volume do som e também ao tráfico de drogas (ESSINGER, Silvio, op. cit. p. 132 et seq.). No Chapéu Mangueira, durante algum tempo, propôs-se, como solução para a convivência do baile com seus "vizinhos", a construção de uma concha acústica no local da quadra (HERSCHMANN, Micael, op. cit. p. 105-106, 170-171); MEDEIROS, Janaína, op. cit. p. 55-56.

${ }^{20}$ HERSCHMANN, Micael, op. cit. p. 181. Uma análise jurídica e criminológica completa, até o ano de 2006, da legislação que regula o funk é feita no capítulo 4 de MARTINS, Denis. Direito e cultura popular: o batidão do funk carioca no ordenamento jurídico. 2006. $130 \mathrm{fl}$. Monografia-Faculdade de Direito, UERJ, Rio de Janeiro, 2006. Nesta introdução, serão abordadas apenas as leis municipais e estaduais aprovadas e não os diversos projetos de lei sobre o assunto não aprovados, incluindo o de $\mathrm{n}^{\circ} 1075 / 99$, do Deputado Estadual Sivuca (PSC), que visava proibir a realização de bailes funks em todo o território brasileiro.

${ }^{21}$ A Lei Pitanga, todavia, não garantiu que os bailes de comunidade não fossem interditados, a despeito da sua tranquilidade e popularidade (HERSCHMANN, Micael, op. cit. p. 170-171).

${ }^{22}$ ESSINGER, Silvio, op. cit. p. 185.
} 
A acusação formal para a invasão de sua casa foi porte ilegal de arma de uso exclusivo das Forças Armadas. Por ser militar reformado, o dono da $\mathrm{ZZ}$ foi mandado para a prisão do $1^{\circ}$ Distrito Naval. Os jornais, enquanto isso, chamaram a atenção para a denúncia de um ex-empregado de Zezinho, que relatava que o empresário era ligado ao Comando Vermelho, fazia o transporte de drogas em seus caminhões e recebia um percentual pelo que fosse consumido. Assim, o homem forte do funk acabou ficando preso por um ano. ${ }^{23}$

Em $1^{\circ}$ de dezembro de 1999, foi a vez de Rômulo Costa, dono da equipe de som Furacão 2000, ser detido sob a acusação de praticar apologia ao crime, corrupção de menores e falsidade ideológica. A acusação tinha base em uma agenda, do ano de 2000, em que traficantes do Morro do Chapadão relacionavam o nome da equipe com os supostos pagamentos de bailes. ${ }^{24} \mathrm{Na}$ mesma época, a Assembleia Legislativa do Estado do Rio de Janeiro instaurou, por meio da resolução 182/99, uma Comissão Parlamentar de Inquérito com o objetivo de "investigar os 'bailes funk' com indícios de violência, drogas e desvio de comportamento do público infanto-juvenil" (artigo $1^{\circ}$ ). No projeto da resolução, apresentou-se como justificativa para a investigação o que segue:

\begin{abstract}
Estamos assistindo frequentemente pela imprensa, a violência gerada neste segmento social. É notório nestes bailes, a ingestão de bebidas alcoólicas vendidas a adolescentes, e o consumo de drogas. O comissariado de menores recentemente apontou estes fatos, sem falar na violência nestes recintos. A sociedade espera que o Poder Público apure estes desvios comportamentais causando graves lesões corporais e até mortes. Recentemente num clube na zona da Leopoldina, em Ramos, houve morte de um adolescente de 12 anos, e foi constatada a irregularidade de alvará de licença autorizando o funcionamento desta atividade. Estamos cumprindo o nosso papel, esperamos contar com o apoio da sociedade, imprensa e membros de Casa. $^{25}$
\end{abstract}

A Comissão, presidida pelo deputado Alberto Brizola (PFL), reuniu-se de novembro de 1999 a maio de 2000. Ao longo de seus trabalhos, convocou para depoimento os principais promotores do funk e as autoridades que ofereceram denúncias, bem como

\footnotetext{
${ }^{23}$ ESSINGER, Silvio, op. cit. p. 193-194.

${ }^{24}$ Verônica Costa, ex-mulher de Rômulo, diz que tudo aconteceu por causa da tentativa de achaque de um delegado. Caso não fossem pagos R 300 mil, ela e o marido se veriam nas páginas policiais como associados do tráfico. Pagaram pra ver e dois dias depois, foi encontrada a tal agenda no Morro do Chapadão, "onde a gente nunca fez baile". Ela pediu ajuda no rádio e o apelo chegou aos ouvidos de Rubem César Fernandes, da ONG Viva Rio, que a levou a um dos advogados mais famosos do Rio, Arthur Lavigne. Rômulo acabou passando somente 15 dias na carceragem de Campinho. A liminar de soltura foi concedida pelo desembargador Mota Morais, da $7^{\mathrm{a}}$ Câmara Criminal, que alegou não haver nenhuma prova para manter preso o dono do Furacão (Ibid. p. 194-195).

${ }^{25}$ Cf. MARTINS, Denis, op. cit. p. 89 et seq.
} 
elaborou uma lista com cerca de trinta bailes que sofreram intervenção de quarenta dias "para manter a integridade física de seus frequentadores". Como resultado prático, o principal feito da CPI foi o de propor um projeto de lei tendente a disciplinar a organização de bailes funk, cuja justificativa segue abaixo:

\begin{abstract}
A conclusão dos trabalhos da Comissão Parlamentar de Inquérito, instituída pela Resolução $n^{\text {o }}$ 182/99 para investigar os chamados bailes Funk, indica a necessidade da edição de legislação para esses tipos de eventos. As audiências realizadas com responsáveis pelos bailes tipo Funk e com pessoas envolvidas com os seus atos, além da avaliação dos procedimentos verificados leva os parlamentares nomeados pelo ato $\mathrm{E} / \mathrm{GP} / \mathrm{N}^{\circ}$ 95/99, a constatar inícios de violência, a existência de drogas e desvio de comportamentos entre os jovens frequentadores dessas promoções - em determinados casos, induzidos por seus responsáveis -, fatos que justificam a presente proposição assinada pelos deputados que compõem a referida $\mathrm{CPI} .^{26}$
\end{abstract}

O projeto de lei 1.392/2000 foi aprovado e resultou na lei estadual 3.410/00. Seu artigo $2^{\circ}$ estabelece a obrigação de instalação de detectores de metais nas portarias dos clubes, entidades e locais fechados em que são realizados os bailes funk. $\mathrm{O}$ artigo $3^{\circ}$ dispôs que só seria "permitida a realização de bailes Funk em todo o território do Estado do Rio de Janeiro com a presença de policiais militares, do início ao encerramento do evento". Segundo a redação do artigo $4^{\circ}$, “os responsáveis pelos acontecimentos de que trata esta lei deverão solicitar, por escrito, e previamente, autorização da autoridade policial para a sua realização, respeitada a legislação em vigor".

De acordo com o disposto no artigo $5^{\circ}$, "a Força Policial poderá interditar o clube e/ou local em que ocorrer atos de violência incentivada, erotismo e de pornografia, bem como onde se constatar o chamado corredor da morte". O artigo $6^{\circ}$ proibiu "a execução de músicas e procedimentos de apologia ao crime nos locais em que se realizam eventos sociais e esportivos de quaisquer natureza" e o artigo $7^{\circ}$ atribui à autoridade policial a adoção de "atos de fiscalização intensa para proibir a venda de bebidas alcoólicas a crianças e adolescentes, nos clubes e estabelecimento de fins comerciais".

Rômulo Costa, que aguardava julgamento em liberdade, teve uma nova prisão decretada em 31 de outubro de 2000, tendo permanecido encarcerado na Polinter por 27 dias. As acusações, com base em investigações do Ministério Público, eram de envolvimento com o tráfico de drogas e associação para fins de tráfico. Por outro lado,

\footnotetext{
${ }^{26}$ MARTINS, Denis, op. cit. p. 98 et seq.
} 
ainda em 2000, Verônica Costa, sua esposa na época, foi eleita vereadora pelo PL com 37 mil votos, a quarta maior votação daquele ano, para defender os interesses do funk. ${ }^{27}$

Em 2004, a lei estadual 4.264/04, proposta pelo deputado Alessandro Calazans (PV), retomou a direção adotada pela lei municipal 2.518/96, reconhecendo os bailes funk como "atividade cultural de caráter popular", desta vez em âmbito estadual. O parágrafo único do artigo $2^{\circ}$ previu que "a realização dos Bailes Funk será regulada através de um contrato previamente assinado entre os organizadores e a entidade contratante, e este contrato ficará disponível para ser apresentado, sempre que solicitado, à autoridade pública fiscalizadora". O artigo $3^{\circ}$ atribui aos organizadores a "adequação das instalações necessárias para a realização dos bailes sob sua responsabilidade, dentro dos parâmetros estabelecidos na legislação vigente".

Já o artigo $4^{\circ}$ atribui "aos organizadores, bem como às entidades contratantes dos eventos, a garantia das condições de segurança da área interna dos bailes, seja em ambientes fechados ou abertos”. De acordo com o disposto em seu parágrafo único, “deverá haver também classificação prévia do Juizado de Menores, que se pronunciará quando à idade e ao horário, não podendo, no entanto, o horário se estender após as 04 (quatro) horas". Segue a exposição de motivos da lei:

\footnotetext{
O movimento FUNK constitui-se hoje em uma atividade de lazer e cultura popular das mais importantes do país, reunindo em torno de 1 milhão de jovens apenas na Região Metropolitana do Rio de Janeiro. Assim como ocorreu com o rock, a capoeira, o reggae, o samba e a hoje considerada inocente valsa que é, à época, chegou a ser motivo de escândalos, o FUNK enfrenta toda ordem de discriminação e tentativas de desmobilização por parte de segmentos da sociedade que vêem este movimento como inúmeros outros, nascidos das chamadas classes subalternas. [grifo no original] Há uma tentativa de associar o movimento FUNK à violência, sem nenhuma base de realidade consistente. Os atos porventura ocorridos à saída dos bailes têm sua origem na ausência do Poder Público e em ocorrências sem quaisquer relações com os bailes, como tem sido apurado quando a investigação desses fatos é séria.

O movimento FUNK mobiliza um grande grupo de pequenos empresários, produtores de música, discos, equipes de som, revistas e programas de rádio $\mathrm{e}$ TV, ligados a esta manifestação cultural de caráter popular, constituindo-se em atividade econômica importante como fonte geradora de novos empregos.

Contudo, o Poder Público tem estado ausente nas suas responsabilidades, especialmente na questão da segurança e do transporte, contraditoriamente às posturas adotadas frente a eventos de semelhante porte e mobilização de público. Há inclusive, um sem número de exemplos de tentativas de proibição de bailes Funk, seja por parte de Prefeituras e Câmaras Municipais, seja por parte de organismos policiais ou órgãos do Poder Judiciário.
}

\footnotetext{
${ }^{27}$ Verônica afirma: "a gente apoiou muitos prefeitos, governadores, muita gente. E sempre na hora que o bicho pegava e vinham as perseguições- policiais, delegados e juízes querendo nos extorquir-, a gente ia pedir ajuda aos políticos e eles falavam que o funkeiro não tinha documento e não votava" (Apud ESSINGER, Silvio, op. cit. p. 195-197).
} 
Acreditamos que os conflitos de interesses que possam surgir entre os organizadores dos bailes e a vizinhança local podem ser perfeitamente solucionados, através de uma negociação pacífica entre as partes, tendo como mediadores representantes credenciados do Poder Público e dos moradores locais. Neste sentido, com o presente Projeto, pretendemos oferecer soluções para a problemática enunciada e garantir a realização harmoniosa desta que é hoje uma importante atividade de caráter popular. ${ }^{28}$

Vice-governador, secretário de Justiça e chefe de Polícia Civil do Rio de Janeiro em 1992, época em que se iniciou o processo de criminalização do funk, Nilo Batista, antigo defensor dos funkeiros, retomou a causa em outubro de 2005, quando, após uma série de reportagens do jornal $O$ Dia, vários MCs voltaram a ser indiciados por suposta apologia ao crime:

\footnotetext{
Quando começou esse novo processo de criminalização, organizei uma grande corrente de advogados. Um repórter veio me perguntar se proibidão é arte. E eu respondi 'a única coisa que eu sei é que a constituição garante a livre expressão do pensamento e livre expressão artística. Não me compete dizer que essa arte pode ou não pode. Isso é o que vocês estão fazendo`. Então convoquei uns colegas meus, excelentes advogados criminais. Todos se dispuseram e fiz um pool de advocacia que ficou à disposição do funk. Ali se adequou um advogado para cada um dos MCs que estavam sendo intimados para comparecer à polícia. $^{29}$
}

A Lei estadual 5.265/08, de autoria do deputado Álvaro Lins (PMDB), revogou a Lei estadual 3.410/00 e impôs uma série de empecilhos para a realização dos bailes funk, de tal forma que tornou praticamente impossível a organização de um baile lícito. Além disso, conferiu à autoridade policial uma grande margem de discricionariedade para proibir ou fechar bailes em nome da "ordem pública". O artigo $3^{\circ}$ dispõe que "os interessados em realizar os eventos de que trata esta Lei deverão solicitar a respectiva autorização à Secretaria de Estado de Segurança - SESEG, com antecedência mínima de 30 (trinta) dias úteis", mediante a apresentação de diversos documentos.

Entre os documentos exigidos, está o contrato da empresa encarregada pela segurança interna do evento e devidamente autorizada pela Polícia Federal; o comprovante de instalação de detectores de metal, câmeras e dispositivos de gravação de imagens; o comprovante de previsão de atendimento médico de emergência, com, no mínimo, um médico socorrista, um enfermeiro e um técnico de enfermagem; e "nada a opor da

\footnotetext{
${ }^{28}$ MARTIS, Denis, op. cit. p. 108 et seq.

${ }^{29}$ Apud MEDEIROS, Janaína, op. cit. p. 105-107.
} 
Delegacia Policial, do Batalhão da Polícia Militar, do Corpo de Bombeiros, todos da área do evento, e do Juizado de Menores da respectiva Comarca" (inciso I, alíneas "e" a "h").

$\mathrm{O}$ artigo $4^{\circ}$ permite à autoridade responsável pela concessão da autorização "limitar o horário de duração do evento, que não excederá a 12 (doze) horas, de forma a não perturbar o sossego público, podendo ser revisto a pedido do interessado ou para a preservação da ordem pública". O artigo $6^{\circ}$ prevê a obrigatoriedade da "instalação de câmeras de filmagem e a gravação das imagens do evento, devendo o vídeo permanecer à disposição da autoridade policial por seis meses após o evento”. Seu parágrafo único dispõe que "o local de entrada onde serão realizadas as revistas dos frequentadores deverá ter cobertura das câmeras de filmagens, devendo ser devidamente iluminado".

De acordo com o disposto no artigo $7^{\circ}$, “a regulamentação da presente Lei disporá sobre o órgão da Secretaria de Estado de Segurança - SESEG responsável pela fiscalização e autuação nos casos de descumprimento dos preceitos desta Lei”. Seu parágrafo único prescreve que "o órgão de fiscalização velará pelo cumprimento do disposto nesta Lei e adotará as providências necessárias para inibir a prática de qualquer infração penal durante a realização do evento" e o artigo $8^{\circ}$ elenca as penalidades a que estão sujeitos o infrator, sem prejuízo das sanções cíveis e penais.

Finalmente, após a mobilização de MCs, organizadores de bailes, políticos e intelectuais, principalmente em torno da APAFUNK (Associação dos Profissionais e Amigos do Funk), criada em 2008, foi aprovada a lei estadual 5.543/09, de autoria dos deputados Marcelo Freixo (PSOL) e Wagner Montes (PDT). O artigo $1^{\circ}$, caput, reconhece o funk como movimento cultural de caráter popular, mas não se aplica em relação a conteúdos que façam apologia ao crime (artigo $1^{\circ}$, parágrafo único). $\mathrm{O}$ artigo $2^{\circ}$ atribui ao poder público a competência de assegurar "a esse movimento a realização de suas manifestações próprias, como festas, bailes, reuniões, sem quaisquer regras discriminatórias e nem diferentes das que regem outras manifestações da mesma natureza"

$\mathrm{O}$ artigo $3^{\circ}$ prescreve que os "assuntos relativos ao funk deverão, prioritariamente, ser tratados pelos órgãos do Estado relacionados à cultura". O artigo $4^{\circ}$ proíbe "qualquer tipo de discriminação ou preconceito, seja de natureza social, racial, cultural ou administrativa contra o movimento funk ou seus integrantes" e o artigo $5^{\circ}$ reconhece os artistas do funk como "agentes da cultura popular", que, como tal, "devem ter seus direitos respeitados". A lei estadual 5.544/09, de autoria dos deputados Marcelo Freixo (PSOL) e 
Paulo Melo (PMDB), por sua vez, revogou a Lei 5.265/08 e manteve a revogação da Lei $3.410 / 00 .^{30}$

${ }^{30} \mathrm{O}$ funk não foi alvo apenas dos Poderes Legislativo e Executivo. Alguns Acórdãos do Tribunal de Justiça do Estado do Rio de Janeiro envolvendo de alguma forma o funk e o baile funk serão expostos nos capítulos seguintes. 


\section{O ARRASTÃo}

\subsection{O caos chega à Zona Sul}

Hermano Vianna identifica um marco na história da relação entre o funk do Rio de Janeiro e o desenvolvimento da percepção da violência (e das causas dessa violência) na vida recente da cidade. Trata-se do "arrastão" que aconteceu na praia do Arpoador, no domingo ensolarado de 18 de outubro de $1992 .{ }^{31}$ O tumulto causado na praia da Zona Sul foi noticiado histericamente pelos meios de comunicação e associado aos distúrbios de Los Angeles do mesmo ano. ${ }^{32}$ A responsabilidade foi atribuída a jovens frequentadores de bailes funk do subúrbio e favelas, rotulados nos editoriais, "Cadernos Cidade" e cartas de leitores, de "gangues urbanas", "bárbaros", “animais", "juventude transviada, desajustada, revoltada e desesperançada", "criadores de pânico e terror". 33

Segundo Vianna, "o que é exótico nem sempre está distante. Numa grande cidade, o exótico pode morar ao lado e nunca ser familiarizado. $\mathrm{O}$ arrastão foi o 'operador lógico` que subitamente transformou o funk exótico num funk familiar". Porém, a transformação familiarizante nem sempre é uma domesticação e o funk ficou muito mais "selvagem" ao se tornar familiar. Antes do arrastão, os bailes funk, apesar de mobilizarem aproximadamente 1,5 milhões de jovens todo fim de semana no Rio de Janeiro, eram um fenômeno desconhecido pela classe média e alta da cidade e relativamente ignorado pela mídia, que, quando tratava do assunto, não focava tanto no aspecto da violência. Mesmo reconhecendo que uma redação de jornal não é homogênea, Vianna questiona o que fez

\footnotetext{
${ }^{31}$ VIANNA, Hermano. O funk como símbolo da violência carioca. In: Cidadania e Violência. VELHO, Gilberto; ALVITO, Marcos. Rio de Janeiro: UFRJ/FGV, 2000. p. 180.

${ }^{32} \mathrm{Na}$ ocasião, a absolvição de quatro policiais brancos, que haviam sido filmados espancando um taxista negro, desencadeou uma série de depredações e confrontos raciais que deixaram mortos e muitos feridos.

${ }^{33}$ Em um editorial mais incisivo, lê-se que "não há distinção entre funk, favela e tráfico de drogas no Rio", que os bailes são um "caso de polícia e deveriam ser combatidos em nome da paz social". Cf. HERSCHMANN, Micael. O funk $e$ o hip hop invadem a cena. Rio de Janeiro: Editora UFRJ, 2000. p. 93 et seq., 102. Analisando 125 artigos na mídia impressa, Micael Herschmann atestou que o funk praticamente inexiste no cenário midiático antes de 1992. Entre 1992 e 1996 ocorre um processo de criminalização e, por outro lado, um processo de afirmação e reconhecimento do funk como uma importante expressão cultural e segmento de mercado significativo. Os artigos analisados foram retirados de O Globo, JB, O Dia e Folha de S. Paulo. Dos 3 artigos levantados e analisados em 1990/1991, 100\% estavam nos cadernos culturais. Dos 19 artigos de 1992, 94,8\% estavam nos cadernos policiais e cidade e 5,2\% nos cadernos culturais. Dos 15 artigos de 1993, 66,6\% estavam nos cadernos policiais e cidade e 33,4\% nos cadernos culturais. Dos 31 artigos de 1994, 58\% estavam nos cadernos policiais e cidade e $42 \%$ nos cadernos culturais. Dos 40 artigos de 1995 , 65\% estavam nos cadernos policiais e cidade e 35\% nos cadernos culturais. Dos 17 artigos de 1996, 47,1\% estavam nos cadernos policiais e cidade e 52,9\% nos cadernos culturais. Dos 125 artigos no total, 56\% estavam nos cadernos policiais e cidade e $44 \%$ nos cadernos culturais (Ibid. p. 94 ).
} 
com que, aparentemente de uma hora para outra, os jornais passassem a retratar o funk como um fenômeno, antes de qualquer coisa, violento; quais grupos sociais (e seus diferentes interesses) estiveram envolvidos na criação dessa nova imagem e o que, no funk, tornou mais fácil sua aplicação. ${ }^{34}$ São exatamente estas questões que serão discutidas no presente trabalho.

\subsection{Fabricando um arrastão}

O termo "arrastão" remete a "pesca predatória", uma ação praticada, a partir dos anos 80, na arquibancada geral e na saída do Maracanã em dias de grandes jogos. De acordo com Kleber Mendonça, o termo passou a designar diferentes eventos de violência, com origens e objetivos específicos. Desde as depredações durante a saída das galeras dos bailes funk de subúrbios até a ação de grevistas e protestos dos camelôs impedidos de instalar suas barracas. Em 1991, o arrastão, em todas as suas variantes, era tratado apenas como um tipo de assalto. Referir-se aos protestos dos camelôs do Rio como arrastão, portanto, conferia àquela manifestação um significado de violência e ilegalidade.

A primeira aparição do arrastão nas praias cariocas se deu em 1984, quando os jornais noticiaram a ação de grupos de "pivetes" no Arpoador e em Ipanema. Naquele verão, a Polícia Militar já previa um possível confronto decorrente do encontro de gangues de favelas nas praias da zona sul. De 1984 a 1990, os arrastões de praia praticamente desapareceram, pelo menos do noticiário, vindo a ressurgir em 1991. Apesar de os jornais continuarem a utilizar a denominação antiga, a partir de 1992, o arrastão passou a ter um caráter muito mais próximo de uma briga de quadrilhas ou galeras funk do que propriamente uma prática que visava ao assalto a turistas, banhistas ou moradores. ${ }^{35}$

O termo passa a designar um tipo de "tumulto" promovido por grupos de jovens pobres, que correm de forma compacta em áreas densamente ocupadas da cidade, supostamente pegando o que podem pelo caminho, ou ainda, qualquer tipo de ação coletiva mais radical e/ou violenta de um grupo oriundo dos segmentos populares no espaço urbano, reificando a sensação de medo no imaginário coletivo urbano ${ }^{36}$. O termo

\footnotetext{
${ }^{34}$ VIANNA, Hermano, op. cit. p. 181 et seq.

${ }^{35}$ MENDONÇA, Kleber. A onda do arrastão. In: Discursos Sediciosos: crime, direito e sociedade. Rio de Janeiro: Freitas Bastos/Instituto Carioca de Criminologia, ano 4, no 7-8, 1999. p. 267-269.

${ }^{36}$ HERSCHMANN, Micael, op. cit. p. 27-28.
} 
"funkeiro", por sua vez, substitui o termo "pivete", passando a designar na imprensa a juventude "perigosa" das favelas e periferias da cidade. ${ }^{37}$

Segundo Cecchetto, “os discursos e práticas vindos da população, da polícia e administradores públicos exibem uma preocupação em coibir a violência das galeras em determinados espaços da cidade. O que chama atenção é que em alguns contextos ela é admitida". ${ }^{38}$ Até 1992, o arrastão era um fenômeno exclusivo das noites sem lei dos bailes funk nos subúrbios. Ocorreu, então, que as galeras de Vigário Geral e de Parada de Lucas, que haviam se estranhado em um baile funk, marcaram um encontro no dia seguinte em Ipanema, um dos destinos favoritos dos funkeiros, devido também à linha de ônibus que tinha na Praça do Arpoador o seu ponto final. A própria polícia reconheceu que o “arrastão" não teve o propósito de roubar os banhistas, ${ }^{39}$ embora o número reduzido de roubos registrados tenha sido hiperdimensionado intencionalmente pela mídia como "a maior sucessão de arrastões da história do Rio de Janeiro".40

A esse respeito, vale citar a seguinte jurisprudência sobre "arrastões", coletada do Tribunal de Justiça do Rio de Janeiro:

\begin{abstract}
0029669-31.2002.8.19.0000 (2002.050.04484) - APELACAO
DES. INDIO BRASILEIRO ROCHA - Julgamento: 21/07/2003 - TERCEIRA

CAMARA CRIMINAL

Os próprios depoimentos das vítimas deixam a idéia de que a subtração de seus bens pelos Réus resultou da rivalidade entre grupos de rapazes que habitam comunidades distintas, inexistindo na sua ação o dolo de roubar, indispensável ao tipo. Segundo se depreende daqueles depoimentos, os réus chegaram ao local em que as vítimas se banhavam em uma represa da CELF e, ali, lhes disseram que o seu objetivo era pôr fim às divergências existentes entre os grupos rivais. Estando as vítimas dentro dágua, os réus se apoderaram de alguns de seus pertences- um boné e um telefone celular, possivelmente, também, uma camisa-e disseram às vítimas que os fossem recuperar em seu bairro (...) Em suas alegações finais, o próprio órgão do Ministério Público interpretou assim o episódio, ao dizer que "O mote do crime, conforme se depreende pelos
\end{abstract}

\footnotetext{
${ }^{37}$ HERSCHMANN, Micael, op. cit. p. 67.

${ }^{38}$ CECCHETTO, Fátima. As galeras funk cariocas: entre o lúdico e o violento. In: VIANNA, Hermano (Org.). Galeras cariocas: territórios de conflitos e encontros culturais. Rio de Janeiro: Editora da UFRJ, 1997. p. 96. O único lugar de grande porte que se disponibilizou a hospedar o primeiro baile funk de Salvador foi o Esporte Clube de Periperi, no subúrbio, completamente fora dos olhares da mídia baiana, que pouco comenta "a vida suburbana", a não ser em caso de crimes ou grandes tragédias (SANSONE, Livio. Funk baiano: uma versão local de um fenômeno global? In: HERSCHMANN, Micael (Org.). Abalando os anos 90: funk e hip hop: globalização, violência e estilo cultural. Rio de Janeiro: Rocco, 1997. p. 176).

${ }^{39}$ ESSINGER, Silvio. Batidão: uma história do funk. Rio de Janeiro: Record, 2005. p. 124-125.

${ }^{40}$ MENDONÇA, Kleber, op. cit. p. 275; RIBEIRO, Manoel. "Funk'n Rio: vilão ou big business?" In: Revista do Patrimônio Histórico e Artístico Nacional, n. 24. Ministério da Cultura, IPHAN, 1996. p. 288. Nilo Batista, então vice-governador do Rio e secretário de Justiça e de Polícia Civil, declara: "Eu tenho um levantamento completo do que aconteceu ali. Não teve uma vítima, não teve uma pessoa ferida. Só teve um furto de uma toalha ou um par de sandálias havaianas. Ridículo" (Apud MEDEIROS, Janaína. Funk carioca: crime ou cultura?: o som dá medo: e prazer. São Paulo: Editora Terceiro Nome, 2006. p. 54).
} 
depoimentos, foi a intenção dos acusados em fazer com que os lesados, que pertencem a outro bairro e consequentemente, a outra 'galera', fossem até o bairro dos agentes recuperar os pertences e assim porem fim aos conflitos".

0037151-64.2001.8.19.0000 (2001.050.02789) - APELACAO

DES. LIBORNI SIQUEIRA - Julgamento: 07/03/2002 - OITAVA CAMARA CRIMINAL

A nobre representante do Ministério Público, em suas alegações finais de fls. 155/156, analisou a prova e chegou à seguinte conclusão:“A atitude dos réus, ao que parece, caracteriza-se muito mais como afronta pessoal em relação a Carlos Eduardo, do que a subtração em si. Ateste-se que o delito do artigo 157 exige o dolo de subtrair, e este dolo, pela prova que foi produzida, não restou individualizado na hipótese. Porque (sic) não subtraíram bens do dono da van, de seu cobrador e dos demais passageiros? (...) [A agressão ao dono da van e ao cobrador] se deu muito mais como represália pelo fato de estarem sendo expulsos da van do que com a finalidade de subtração de bens, a qual, em relação a estas vítimas, sequer ocorreu". Ofertando as contra-razões de fls. 209/211 a insigne Promotora as ratifica, concluindo: "A própria atitude de subtrair boné e camiseta do lesado, demonstra a disputa de espaço, a qual se individualiza, muitas vezes, nestes bailes, pelas vestimentas dos diversos grupos existentes (...)". (...) É fácil concluirmos que houve um tumulto decorrente dos costumeiros embates de "gangues de Funkeiros". Todos procediam de um baile "Funk", às 05:00 horas da madrugada.

Segundo a polícia, as galeras, há muito tempo, haviam loteado parte das duas praias e uma das turmas invadiu o espaço delimitado pela outra. Estes adolescentes geralmente brigam sempre que se encontram, seja num baile funk, na praia ou no Maracanã. E alguns tentam reproduzir a guerra travada entre as organizações criminosas. ${ }^{41} \mathrm{O}$ encontro na areia das turmas rivais provocou um corre-corre, assustando os banhistas, que também passaram a correr. O tumulto ainda foi potencializado devido ao número insuficiente de ônibus nos pontos finais para levar os jovens de volta a seus bairros. Os policiais afirmaram que aconteceu à luz do dia o que costuma acontecer nas saídas dos bailes funk: "essas pessoas, que andam em grupos, têm um comportamento anti-social e vão fazendo baderna por onde passam.". 42

Vianna interpreta o episódio como uma tentativa das galeras de diferentes favelas cariocas de "encenar na areia da praia o 'teatro da violência` que inventaram nas pistas de dança das centenas de bailes funk realizados semanalmente em quase todos os bairros da cidade". ${ }^{43}$ Enfim, pode-se indagar se o que ocorreu naquele 18 de outubro foi mesmo um acontecimento violento ou criminoso. Afinal, muito do que os sujeitos acreditam ser "crime moral" não é "crime legal". O crime moral corresponde às ideias populares, ou

\footnotetext{
${ }^{41}$ CUNHA, Olívia M. G. Bonde do mal. In: MAGGIE, Yvonne; REZENDE, Cláudia B. (org). Raça como retórica: a construção da diferença. Rio de Janeiro: Civilização Brasileira, 2001. p. 97.

${ }^{42}$ HERSCHMANN, Micael, op. cit. p. 96.

${ }^{43}$ VIANNA, Hermano, op. cit. p. 180.
} 
melhor, fora da legislação estatal, acerca do que agentes e grupos sociais compreendem ser uma conduta ou atitude criminosa. ${ }^{44}$

Pequenas incivilidades cometidas no espaço público podem gerar o sentimento de insegurança, quando não a simples presença de pessoas vistas como ameaçadoras. Neste ponto, o pânico causado pelo arrastão pode esconder, no fundo, apenas a intolerância à presença de determinados grupos sociais em determinados espaços da cidade que gozam de status em virtude de sua frequência habitual, como é o caso das praias da Zona Sul carioca. O arrastão, desta forma, é associado à invasão ruidosa de suburbanos "selvagens". Na narrativa de um dos participantes do "arrastão", a violência policial e a instigação de repórteres foram o que deflagrou tanto o confronto quanto a incompreensão e o pânico. ${ }^{45}$

No "jornalismo participativo", qualquer um pode dizer qualquer coisa em qualquer lugar, mas o que lhes dá credibilidade continua a ser a chancela do jornalismo. A repetição da informação, principalmente por autoridades como a polícia e a mídia, a tornam verdadeira, independentemente se o rigor, a objetividade, o cruzamento de várias fontes ou o simples bom senso e perspicácia levam a uma conclusão oposta. No calor da hora, que é a hora do jornalismo, a tendência é acatar a interpretação socialmente mais aceita, o que por sua vez reforça as expectativas já presentes no senso comum, ou seja, as pessoas acreditam porque querem acreditar, porque já havia esta predisposição.

A invenção de um acontecimento falso torna-se possível e plausível quando ele já era de certo modo esperado e desejado pela máquina social de fabricação e de interpretação dos acontecimentos. Tem-se necessidade de acontecimentos, mesmo falsos, porque suas interpretações preexistem e chamam esses acontecimentos. Um não-acontecimento é sempre um acontecimento que se ignora. O risco de sancionar um falso sintoma é menor do que o de ignorar um verdadeiro e de não parecer interessar-se pelos sintomas. E assim, a fabricação de arrastões pela mídia ajuda a difundir o ódio contra um determinado setor da

\footnotetext{
${ }^{44}$ Um relato etnográfico de um crime moral cometido em Copacabana pode ser encontrado em SILVA, Rejane Valvano Corrêa da; COUCEIRO, Luiz Alberto. "Pega o bandido corno!": práticas e representações de crime e violência num bairro da zona sul do Rio de Janeiro. In: Discursos Sediciosos: crime, direito e sociedade. Rio de Janeiro: Freitas Bastos/Instituto Carioca de Criminologia, $\mathrm{n}^{\circ} 15-16,1^{\circ}$ e $2^{\circ}$ semestres de 2007. p. 221, 225.

45 "Nós chegamos na moral e os polícia começou a olhar pra gente assim... (...) Nós começamos a bater o pagode e falaram que é bagunça: 'pode parar'. Aí tomou os instrumentos da gente... (...) Daí a um pouquinho volta[m]: 'Aí, vamos parar com a bagunça. Vai parando logo, vai se destacando aí. Vai dando um rolê'. E começou a bicar nego (...) De repente um cara [gritou] 'Olha lá, olha lá os alemão` (...) Os gringo ficou em pânico (...) e os repórteres tudo atiçando: 'Vai bater naquele ali, ta tacando mais pedras do que vocês!' Quando vai ver: arrastão de praia. Que eu saiba, arrastão é roubo, né? Como é que não roubaram nada nesse dia? Nesse dia foi só tumulto, mas arrastão não teve não (CUNHA, Olívia M. G, op. cit. p. 85-86).
} 
população e legitimar ações repressivas. ${ }^{46}$ A disseminação do pânico moral é refletida nas pesquisas de opinião, cujos resultados, também manipulados, confirmam as teses do jornal e eternizam o ciclo vicioso. ${ }^{47}$

Os grupos sociais excluídos são automaticamente suspeitos e sua mera aparição num contexto tenso pode gerar uma atitude violenta. Na reportagem "Boato de arrastão causa pânico no Arpoador e mobiliza 300 PMs”, publicada em O Globo de 18/10/93, a foto que acompanha a matéria mostra que todos os "suspeitos" detidos eram negros, enquanto o box esclarece que o pânico criado com a presença de pessoas "mal-encaradas" fez muita gente "pressentir tudo" e sair correndo. ${ }^{48}$ Ainda que as galeras se diferenciem das gangues, conforme será analisado adiante, a maior violência da polícia, segundo os componentes das gangues, é não efetuar uma diferenciação, tratando todos como criminosos. Assim como as

${ }^{46}$ MORETZSOHN, Sylvia. De Carcavelos ao Leblon: arrastões do preconceito. In: Discursos Sediciosos: crime, direito e sociedade. Rio de Janeiro: Freitas Bastos/Instituto Carioca de Criminologia, no 15-16, 2007. p. 360 et seq.; BATISTA, Vera Malaguti. O medo na cidade do Rio de Janeiro: dois tempos de uma história. Rio de Janeiro: Revan, 2003. p. 21. O jornal se vale de sua credibilidade para atestar declarações de fontes não reveladas, como a da notícia "Funkeiro diz que arrastão se repetirá". No domingo seguinte ao da reportagem, se vê um super-esquema adotado pela polícia, areias esvaziadas pelo medo da classe média e prevenção do suburbano, que não quis se arriscar a ser confundido com funkeiro do arrastão. Realizando a profecia auto-cumprida, o jornal noticia, então, que "O medo esvazia as praias no feriado", baseado na declaração de várias pessoas na praia, que opinavam em favor da tese do jornal em detrimento da ideia de que teria sido o mau tempo o culpado por afastar os banhistas da orla (MENDONÇA, Kleber, op. cit. p. 274). ${ }^{47}$ MENDONÇA, Kleber, op. cit. p. 276; VENTURA, Zuenir, op. cit. p. 97-98.

${ }^{48}$ MENDONÇA, Kleber, op. cit. p. 273. Outro episódio que merece ser mencionado para exemplificar como a repressão é que pode gerar o tumulto, fazendo com que a profecia se auto-realize, é o suposto "arrastão" da praia de Carcavelos, em Cascais, Portugal. Em um feriado em que se verificou um aumento anormal do número de jovens de raça negra no areal, um grupo de jovens negros começou a se reunir na praia. Prevendo problemas, o dono de um bar chamou a polícia. O tumulto se instalou sem origem precisa e logo se generalizou, causando pânico e correria. As imagens a que se conferiu automático status de prova mostravam apenas jovens negros correndo. Isso por si só assusta e gera suspeitas de que se trata de ladrões fugindo. Ocorre que esses jovens sabem que, diante da aproximação da polícia, o mais prudente é correr (MORETZSOHN, Sylvia, op. cit. p. 359-362). Telejornais anunciaram que "cerca de 500 negros, entre 12 e 20 anos, haviam promovido um arrastão, roubando e agredindo tudo e todos que viam pela frente". O fato de ter ocorrido no Dia de Portugal gerou suspeitas sobre intenções políticas de uma ação orquestrada pela segunda geração de imigrantes africanos no país, tida como perdida, "rebelde com causa", perigosa, portadora de uma "subcultura pop identitária". O comandante da polícia metropolitana de Lisboa reconheceu que foi a presença da polícia o elemento desencadeador da confusão e que afirmou se tratar de um arrastão baseado em testemunhas oculares, em um policial "que não soube consubstanciar exatamente o que tinha acontecido" e nos próprios jornalistas que lhe telefonaram cobrando uma posição. A polícia afirmou que "só 30 ou 40 praticaram ilícitos" e "muitos jovens fugiam com seus próprios haveres". Além disso, neste mesmo dia, um grupo de jovens brancos também provocou desacatos no Porto. Já no show dos Racionais MCs na Praça da Sé, na edição de 2007 da Virada Cultural, o público, que se disse provocado pela polícia, acabou depredando as imediações da Praça da Sé. Subir no teto da banca de jornal ou tentar escalar prédios para ter uma visão melhor do palco não é tolerado em um ambiente no qual a mídia e setores diversos da população estão presentes, assim como as tradicionais brigas/danças de "galeras" não são toleradas nas areias do Arpoador, um espaço público. 
galeras, a PM também faz arrastões violentos para demonstrar força, mas nos morros. ${ }^{49}$ Não é preciso ter cometido nenhum ato de delinquência para que os integrantes das gangues sejam indicados culpados. Glória Diógenes assinala que,

\begin{abstract}
na lógica da produção de "vítimas sacrificiais", eles são, desde sempre, autores de infrações. Basta apenas que, como atores-símbolo da violência urbana, iniciem seus espetáculos, suas encenações e possibilitem para a cidade como um todo a visão de que a violência tem um lugar, um ator específico, um outro fora de mim, longe de mim". ${ }^{50}$
\end{abstract}

Nota-se então que o termo "arrastão", que compreendia inicialmente assaltos e ações coletivas e rápidas envolvendo jovens nas praias, trens, ônibus e ruas, passa a referirse à "presença de uma parcela distinta da população como ameaça de violência e desordem". Importa impedir certos tipos de "aglomeração" e demoniza-se um certo tipo de frequência em certas áreas da cidade. ${ }^{51} \mathrm{O}$ arrastão colocou os funkeiros "no meio de um conflito que vem sendo travado sobre o espaço do pobre, seu acesso a bens e serviços de cidadãos e a sua vulnerabilidade ao vigilantismo/vigilância e à violência do Estado". Funkeiros passaram a ser encarados de forma maniqueísta como suburbanos invasores, tentando deter o que pertence às elites e à classe média por meio do medo, que justifica a repressão. $^{52}$

\title{
2.3. O lugar do pobre
}

Segundo Vera Malaguti Batista, “'pobres na praia`e 'arrastão` não motivam as pessoas a pensarem 'poxa, como é que a gente pode tornar o acesso à praia melhor?'. Não. Só personifica o pré-conceito que elas têm e elas pensam 'não quero eles aqui`. Como se isso fosse possível". ${ }^{53}$ Os setores conservadores da sociedade não deixaram barato a invasão do seu "espaço sagrado de lazer" por "hordas de suburbanos selvagens". Surgiram milícias formadas por lutadores de jiu-jitsu, militares reformados, profissionais de organizações anti-sequestro, e intituladas Anjos da Guarda, que tinham supostamente a

\footnotetext{
${ }^{49}$ DIÓGENES, Glória. Gangues e polícia: campos de enfrentamento e estratégias de diferenciação. In: PEREIRA, Carlos Alberto Messeder; RONDELLI, Elizabeth; SCHOLLHAMMER, Karl Erik; HERSCHMANN, Micael (Org). Linguagens da violência. Rio de Janeiro: Rocco, 2000. p. 206.

${ }^{50}$ Ibid. p. 218.

${ }^{51}$ CUNHA, Olívia M. G., op. cit. p. 91-92.

52 YÚDICE, George. A funkificação do Rio. In: HERSCHMANN, Michael (Org.). Abalando os anos 90: funk e hip-hop - globalização, violência e estilo cultural. Rio de Janeiro: Rocco, 1997. op. cit, p. 44-45.

${ }^{53}$ Apud MEDEIROS, Janaína, op. cit. p. 29-30.
} 
missão, paradoxalmente por meio do uso da força, de garantir o direito dos legítimos frequentadores da praia, conter a violência crescente e reduzir o pânico social incentivado pela imprensa.

A estratégia foi bem sucedida em fazer com que vários banhistas habituais da praia deixassem de frequentá-la por serem suburbanos, negros, ou "excluídos" e temerem agressões ou ser confundidos com organizadores de arrastão. Os que tinham o mesmo perfil dos "suspeitos" detidos pela polícia acabaram abandonando a praia junto com os "pivetes". ${ }^{54}$ Uma vez que os jovens suburbanos costumavam ir sempre em grupos para a praia e assim eram pejorativamente identificados, os jovens do Cantagalo, uma favela da Zona Sul, demonstraram a necessidade, em virtude da repressão pós-arrastão, de irem sozinhos e, no máximo, encontrarem com os amigos já na praia, para que não fossem confundidos com baderneiros. ${ }^{55}$ As providências oficiais, apoiadas pela "opinião pública", se limitaram a criar dificuldades de circulação em direção à Zona Sul nos fins de semana e fechar bailes funk nos subúrbios. ${ }^{56}$

Outros importantes reflexos do arrastão foram a demanda por pena de morte e pela presença do Exército nas ruas, invocando-se a "bem sucedida" experiência do Rio-92; a fabricação de mapas da cidade que propunham identificar os locais de proveniência desses jovens e alertar sobre quais eram as "áreas de risco" nas praias ou mesmo na cidade; e a tentativa frustrada de impedir a circulação dos ônibus que faziam o trajeto Norte/Oeste-Sul nos fins de semana, uma vez que várias linhas da periferia faziam ponto final na Praça do Arpoador. ${ }^{57}$ Estas linhas de ônibus incomodavam há algum tempo os "frequentadores legítimos" das praias da Zona Sul e o arrastão foi apenas o ápice para que esta insatisfação viesse à tona de forma legitimada.

Embora a praia carioca seja vendida simbolicamente como o território mais democrático da cidade, espaço de congraçamento de classes e raças diferentes e, portanto, esteja em sintonia com o mito brasileiro da democracia racial, verifica-se que a praia não é

\footnotetext{
${ }^{54}$ MENDONÇA, Kleber, op. cit., p. 273-275. Seguindo a mesma lógica de limpar o cartão postal de elementos poluidores, os grupos de "enfrentamento" das gangues de Fortaleza atuam, com maior intensidade, nos períodos próximos à temporada turística. Nesse momento, ocorre uma verdadeira "varredura" bélica de todo "elemento" que venha a ser confundido com integrante de gangues. Utilizam-se "ninjas encapuzados", cães farejadores, viaturas que fazem rondas sistemáticas nas zonas de perigo, visando com isso ao enfrentamento dos "arrastões" etc. (DIÓGENES, Glória. Rebeldia urbana: tramas de exclusão e violência juvenil. In: HERSCHMANN, Micael (Org). Abalando os anos 90: funk e hip-hop - globalização, violência e estilo cultural. Rio de Janeiro: Rocco, 1997. p. 125-126).

${ }^{55}$ CUNHA, Olívia M. G., op. cit. p. 106.

56 RIBEIRO, Manoel, op. cit. p. 288.

${ }^{57}$ HERSCHMANN, Micael, op. cit. p. 100; ESSINGER, Silvio, op. cit. p. 126.
} 
de todos e que por trás da categoria "carioca", existem múltiplas identidades que espelham status desiguais, como as de "morador da Zona Sul" e "morador da Zona Norte". Já entre os "moradores da Zona Sul”, pode-se identificar os "moradores do asfalto", todos de classe média e alta, os "trabalhadores da Zona Sul”, como empregadas domésticas e porteiros, e os "favelados da Zona Sul”, como os moradores do Vidigal, Cantagalo, Rocinha e PavãoPavãozinho. ${ }^{58}$

Nem todos os cariocas são considerados frequentadores legítimos das praias da Zona Sul, tidas pelos habitantes destes bairros como verdadeiras extensões de suas casas, a ponto de a praia ser loteada, não entre galeras funks rivais, conforme alardeado pela mídia, mas entre os condomínios residenciais. Hotéis chegam a reservar espaços na areia com guarda-sóis e seguranças, para garantir a tranquilidade dos clientes, em uma prática claramente privatizante. ${ }^{59}$

Praias tranquilas, limpas, de areia branca, água límpida e frequentadas apenas por gente bonita, de família e nível social elevado (incluindo turistas, apesar de serem de fora), são opostas à presença de gente feia, barulhenta, mal educada, "selvagem" e grosseira, que gosta de confusão e deixa a praia lotada, suja e decadente. A presença dos suburbanos despejados dos ônibus lotados e associados pela mídia à dejeção, contamina o ambiente, desvalorizando a praia e o próprio mercado imobiliário, ainda mais levando-se em consideração o incremento da violência ou da sensação de insegurança.

Diante dessas considerações, era esperado, portanto, que a criação, pelo exgovernador Leonel Brizola, de linhas de ônibus que facilitassem o acesso às praias da Zona Sul fosse tão fortemente rechaçada pelos moradores e comerciantes da região, que viram a frequência do bairro, e não só da praia, mudar e não aprovaram a tão celebrada integração social. Se na década de 80 a personagem demonizada nas areias da Zona Sul eram as famílias de "farofeiros", na década de 90 passou a ser o jovem "funkeiro", filho bastardo

\footnotetext{
${ }^{58}$ Estas identidades são fluídas e circunstanciais. Os "favelados da Zona Sul”, muitos deles funkeiros, podem vir a incorporar a ideologia dos "moradores do asfalto", responsabilizar os suburbanos pelos arrastões e os expulsar da praia, embora sejam igualmente responsabilizados pelos arrastões, desprezados pelos "moradores do asfalto" e suas condições materiais se assemelhem mais às dos suburbanos (MENDONÇA, Kleber, op. cit. p. 273). Cf. também CUNHA, Olívia M. G., op. cit. p. 103-104.

${ }^{59}$ CUNHA, Olívia M. G., op. cit. p. 87-90, 101, 145-146. Se a "sociabilidade carioca" celebra a indistinção de classes, cores e culturas, a ideia de invasão reafirmaria aspectos particulares e relacionados à coesão de um grupo de pessoas por oposição a outras (Ibid. p. 102).
} 
do "farofeiro" e do "pivete", ou seja, uma personagem igualmente incômoda, mas muito mais violenta. ${ }^{60}$

Quando a ampliação da capacidade de deslocamento urbano permite que os pobres assumam a cidade como sua, eles topam com fronteiras sociais, raciais ou geracionais que os expulsam. ${ }^{61}$ As mesmas classes média e alta que reivindicavam o seu direito de ir e vir à praia, limitado drasticamente pela sensação de insegurança no espaço público, queria limitar o direito de ir e vir das camadas baixas da população. Segundo Bauman, o que marca a pós-modernidade é justamente a contraposição entre mobilidade para as classes altas (flexibilidade da produção, liberdade de mercado, liberdade de iniciativa, mobilidade do capital financeiro, fim das barreiras comerciais, meios de transporte e de comunicação tecnologicamente avançados encurtando as distâncias, etc.) e imobilidade para as classes baixas (sujeição a empregos precários, restrições pesadas para os migrantes, índices elevados de encarceramento, etc.). ${ }^{62}$

Para Milton Santos, o arrastão pode ser entendido como um luta pelo espaço, uma vez que os pobres são prisioneiros de seus bairros e a transversalidade depende do propósito segundo o qual uma pessoa se move de uma área para outra, sendo vedada, por exemplo, para fins de lazer e permitida para fins de trabalho, como é o caso das empregadas domésticas que trabalham na Zona Sul e moram "lá longe". ${ }^{3}$ Sendo a praia ainda o lazer mais barato no Rio de Janeiro, o arrastão nada mais é do que a divisão do bolo. ${ }^{64}$ No seguinte Acórdão, do Tribunal de Justiça do Rio de Janeiro, um arrastão no metrô é descrito como "desordem" que provoca o "clamor público" e o "pânico" na "mente, no corpo e na alma" de "pacatos passageiros". O Desembargador alude a "palavras chulas, de baixo calão, pornográficas, agressivas e torpes", defende que o "famigerado" arrastão tomou conta de "nossas praias, quiçá pela ausência de enérgica e correta reação

\footnotetext{
${ }^{60}$ MENDONÇA, Kleber, op. cit. p. 271-272; CUNHA, Olívia M. G., op. cit. p. 96 et seq. No mesmo ano da implantação das referidas linhas de ônibus, foi iniciada pela polícia a então chamada Operação Verão (Ibid. p. 87 et seq.). É interessante perceber como o ano de 1984 marca ao mesmo tempo a intolerância à invasão dos "farofeiros" e o movimento das Diretas Já. Para Teresa Caldeira, entretanto, não se trata de uma contradição, uma vez que é justamente a democratização do país que possibilita que setores antes excluídos reivindiquem seus direitos de cidadania e ocupem espaços na cidade antes a eles interditados (CALDEIRA, Teresa. Cidade de Muros: crime, segregação e cidadania em São Paulo. São Paulo: Editora 34/Edusp, 2000. p. 327). É esse movimento que pode explicar a busca das classes médias e altas por novas formas de segregação, em resposta aos avanços dos movimentos sociais após a abertura política.

${ }_{61}$ ARCE, José Manuel Valenzuela. Vida de barro duro: cultura popular juvenil e grafite. Rio de Janeiro: Editora UFRJ, 1999. pp. 94-95.

${ }^{62}$ Cf. BAUMAN, Zygmunt. Globalização: as consequências humanas. Rio de Janeiro: Jorge Zahar, 1999. p. 129.

${ }^{63}$ Apud YÚDICE, George, op. cit. p. 38.

${ }^{64}$ CUNHA, Olívia M. G., op. cit. p. 96.
} 
das autoridades constituídas" e que essas manifestações que "conspurcam" o serviço do metrô devem ser "expurgadas em seu nascedouro":

0043800-06.2005.8.19.0000$(\mathbf{2 0 0 5 . 0 5 9 . 0 6 0 0 1})$ - HABEAS CORPUS
DES. IVAN CURY - Julgamento: 22/11/2005 - SETIMA CAMARA
CRIMINAL
HABEAS CORPUS. GRUPO QUE A SIMILITUDE DOS FAMIGERADOS
"ARRASTÕES" QUE INVADIRAM NOSSAS PRAIAS, ADENTRAM EM
VAGÃO DO METRÔ, ONDE PERTURBAM A TRANQUILIDADE DOS
PASSAGEIROS, COM AGRESSÕES RECÍPROCAS, UTILIZANDO
INCLUSIVE OS EXTINTORES DE. INCENDIO,COM DANOS AO
PATRIMONIO DA CONCESSIONÁRIA. ATÉ OS FREIOS MECANICOS DO
VAGÃO FORAM ACIONADOS COM PERIGO DE ACIDENTES NO
LOCAL. OFENSAS AOS PASSAGEIROS COM PALAVRAS, FICAS DE
BAIXO CALÃO E PORNOGRÁFICAS. PRESOS. POSTULAÇÃO
DEFENSIVA DE VIOLAÇÃO DOS DIREITOS CONSTITUCIONAIS DOS
PACIENTES, DE IR E VIR. Sem razão. Os fatos narrados nos autos estão a
merecer severa reprimenda do PODER JUDICIA RIO ceifando no nascedouro a
tentativa de levar ao METRÔ CARIOCA a desordem já instalada nas praias.
Ausência de constrangimento ilegal, mera aplicação do DIREITO POSITIVO.
Prisões em flagrante. Ordem denegada.

\title{
2.4. $O$ cordão atuarial
}

De acordo com Glória Diógenes,

\begin{abstract}
a tentativa de disciplinamento da cidade, por meio da repressão à ação do "desordeiro", expressa a falência nos modelos de "normatização" implementados pelas "instituições de confinamento". A proposta de ordenação e "normalização social" da cidade, que se apoiava no enclausuramento dos "vagabundos", "vadios" e "vândalos", parece ter vivenciado seu esgotamento na década de 1980 (...) Desse modo, o "enfrentamento" e o "combate" à desordem se dão em plena praça pública, sob o princípio de que "o bandido a gente ataca" 65
\end{abstract}

O fenômeno das gangues juvenis traz embutido um conteúdo simbólico similar ao associado aos vagabundos da Idade Média. São rebeldes urbanos, transgressores odiados, sem lugar, domicílio e papel social definido, nômades, forasteiros, que circulam ágil e constantemente e "instauram outra ordem de valores, em que a 'vagabundagem', o 'ócio', a exaltação do 'lazer` e a desvalorização da ética do trabalho parecem pôr em xeque os pilares básicos da sociedade contemporânea". ${ }^{66}$

${ }^{65}$ DIÓGENES, Glória, op. cit. p. 125.

${ }^{66}$ Ibid. p. 127 . Neste ponto, é emblemática a importância que a residência fixa do réu tem para a concessão de liberdade provisória a quem está preventivamente preso. O princípio da localização imediata ou do quadriculamento se resume na máxima "cada indivíduo no seu lugar e em cada lugar um indivíduo", a fim de que se evitem as distribuições por grupos e se anulem os efeitos das repartições indecisas, o desaparecimento 
Por outro lado, em um contexto sócio-econômico no qual amplas parcelas da população constituem o excesso do exército industrial de reserva, elas se tornam supérfluas, descartáveis, e a lógica da disciplina, que guiou a modernidade, é substituída pela lógica do controle. ${ }^{67}$ Não há porque investir mais em instituições disciplinares como a escola e a fábrica, nem em uma política criminal que busque a reintegração do condenado aos setores produtivos, uma vez que nem todos podem ser produtivos nem consumir na pós-modernidade. ${ }^{68}$

A nova criminologia administrativa não busca mais estudar, como na modernidade, as causas da criminalidade para combatê-la, mas tem em relação ao crime uma atitude atuarial, de gestão de riscos. Assume-se a criminalidade simplesmente como um dado inevitável e buscam-se meios para minorar seus riscos e danos, rearranjando a distribuição de criminosos na sociedade e afastando-os das áreas nobres da cidade. ${ }^{69}$ A criminologia atuarial renuncia a qualquer diagnóstico ou avaliação moral sobre os indivíduos, os quais são reagrupados e supervisionados sob a forma de classes perigosas, com base em falsas projeções e prognósticos, cálculos probabilísticos e dados estatísticos viciados. ${ }^{70}$

A abordagem atuarial se preocupa com o cálculo dos riscos em vez de ocupar-se com culpa ou motivação. O desvio passa a ser não um comportamento, mas um status habitual de pessoas não garantidas. ${ }^{71}$ As políticas urbanas também passam a ser atuariais, sanitárias, higienistas, privatizadoras. Em contraposição às análises etnográficas, muitas análises sociológicas costumam enxergar a metrópole pós-moderna como um grande mosaico de diversidade, no qual as múltiplas identidades (étnicas, etárias, culturais etc.) estão fixas e fragmentadas. Nessa visão, o espaço público é caracterizado pelo anonimato.

descontrolado dos indivíduos, sua circulação difusa, sua coagulação inutilizável e perigosa (FOUCAULT, Michel, Vigiar e punir. Petrópolis: Ed. Vozes, 2004. p. 123).

${ }^{67}$ DE GIORGI, Alessandro. A miséria governada através do sistema penal. Rio de Janeiro: Revan, 2006. p. 47 et seq. Cf. DELEUZE, Gilles. Conversações, 1972-1990. Rio de Janeiro: Editora 34, 1992. p. 219 et seq.

${ }^{68}$ Cf. BARATTA, Alessandro. Criminologia crítica e crítica do direito penal. Rio de Janeiro: Revan, 2002. p. 195-196.

${ }^{69}$ FEELEY, Malcolm; SIMON, Jonathan. The new penology: notes on the emerging strategy of corrections and its implicatios. Criminology 30-4, novembro de 1992. p. 458. Cf. também YOUNG, Jock. A sociedade excludente: exclusão social, criminalidade e diferença da modernidade recente. Rio de Janeiro: Revan: Instituto Carioca de Criminologia, 2002. p. 43.

${ }^{70}$ FEELEY, Malcolm; SIMON, Jonathan, op. cit. p. 452. Se a distinção entre os trabalhadores e os bandidos da favela "é tão importante a ponto de ser em torno dela que se constroem as regras de convivência mútua, nas representações de alguns setores da sociedade mais ampla ela desaparece e dá lugar a uma noção que Louis Chevalier chamou de classes perigosas. Além de desassistidos, tratados como criminosos, antes de sêlos. Uma das expressões da dominação é a construção da identidade do dominado pelo dominador. E uma das técnicas repressivas é a estigmatização de quem se quer reprimir. Pobre, criminoso, perigoso" (ZALUAR, Alba. A máquina e a revolta: as organizações populares e o significado da pobreza. São Paulo: Editora Brasiliense, 1985. p. 168).

${ }^{71}$ BARATTA, Alessandro, op. cit. p. 196. 
As pessoas supostamente evitam contato, especialmente em um contexto no qual a percepção da "violência urbana" é cada vez mais acentuada.

O controle social informal da criminalidade passa pela instância da sociedade civil: família, escola, profissão, opinião pública, Igreja, vizinhança, grupos de pressão etc. Quando as instâncias de controle social falham, entram em ação as agências de controle formais, compostas pela Polícia, Ministério Público, Poder Judiciário etc. A efetividade do controle social formal é muito menor do que aquela exercida pelas instâncias informais, uma vez que a vigilância por elas exercidas é permanente. ${ }^{72}$ De acordo com a ecologia criminal da Escola de Chicago, na grande cidade moderna os indivíduos estão rodeados de pessoas que só conhecem limitadamente ou de pessoas que estão sempre partindo e chegando. Esse anonimato torna as relações humanas impessoais e gera um culto à liberdade exacerbada. Os valores sociais da urbe não são mais os da religião, da solidariedade e do companheirismo. Consequentemente, o controle social informal perde força.

A criminalidade, no entanto, não se distribui de forma homogênea pela cidade. Em determinadas áreas, onde a mobilidade de pessoas é maior, a influência das normas sociais de conduta tende a se afrouxar de forma mais significativa, afinal, o indivíduo não tem tanto a perder com a sanção social. Assim, no modelo da Escola de Chicago, a criminalidade tende a ser maior nas chamadas zonas de transição da cidade, bairros que circundam o centro, degradados pela sujeira, o odor e o barulho das fábricas, abandonados pelos membros mais abastados da sociedade e ocupados por migrantes e imigrantes pobres. O processo de perda das raízes sofrido por indivíduos de várias culturas diferentes traz em seu bojo a ideia de desorganização social. O indivíduo perde suas referências normativas, o sentimento de pertencimento a uma comunidade e pratica crimes que em outros contextos, como em cidades menores, onde o controle social informal é mais efetivo, não praticaria. ${ }^{73}$

O ciclo vicioso se consolida, pois a desordem dá um claro sinal de que aquela é uma zona insegura, em franca decadência, pronta a converter-se em território do crime. $\mathrm{O}$

\footnotetext{
${ }^{72}$ SHECAIRA, Sérgio Salomão. Criminologia. São Paulo: Revista dos Tribunais, 2004. p. 56.

${ }^{73}$ Id. Importância e atualidade da Escola de Chicago. In: Discursos Sediciosos: crime, direito e sociedade, v. 9/10. Rio de Janeiro: Freitas Bastos, 2000. p. 158-160; Id. Criminologia. São Paulo: Editora Revista dos Tribunais, 2004. p. 139 et seq. O modelo da Escola de Chicago deve ser aplicado, todavia, com ressalvas, a São Paulo e ao Rio de Janeiro. Ambas possuem áreas centrais degradadas e associadas à criminalidade, mas enquanto em São Paulo as taxas mais elevadas de criminalidade se concentram na periferia, no Rio de Janeiro se concentram nos subúrbios e nas favelas, áreas em que o "espírito comunitário" costuma ser mais forte e o Estado, em sua acepção social, menos presente.
} 
“cidadão de bem" responde racionalmente, retirando-se da rua e evitando certas áreas. ${ }^{74} \mathrm{O}$ espaço público é visto pelas classes médias e altas como território inóspito, onde reina a desordem, a sujeira, a degradação, o medo e a violência. Almejando escapar de todos esses inconvenientes, teriam abandonado a rua, o espaço público por excelência, e se encerrado em enclaves fortificados que garantem a segurança e evitam o risco de contato com as classes sociais baixas, consideradas perigosas e simbolicamente contaminadoras. $\mathrm{O}$ carro, fechado para o mundo externo, é eleito pelas classes mais abastadas o meio de transporte indispensável. No âmbito da moradia, os condomínios fechados garantem a segurança e a homogeneidade de classe. ${ }^{75}$

Na esfera do lazer, os enclaves fortificados também imperam, como se pode notar pelo abundante número de shopping centers na cidade e de serviços por eles oferecidos, como praça de alimentação, cinemas e teatros. Seguranças privados arbitrariamente selecionam quem entra e quem não entra nestes templos do consumo. Há, inclusive, uma importante diferenciação entre shoppings conforme o público frequentador. Apesar de os jovens funkeiros portarem outras identidades, o fato de um jovem assumir a estética do funkeiro acarreta consequências para a sua inserção na cidade. Diversos jovens participantes de galeras declaram se sentir discriminados em determinados espaços, públicos e privados. No espaço do shopping é comum que a segurança acompanhe com maior proximidade a movimentação daqueles que se pareçam com funkeiros, talvez com receio de que eles roubem as lojas ou briguem dentro do shopping ${ }^{76}$.

Segundo Vera Malaguti Batista,

é como se houvesse um zoneamento invisível, inconsciente, em que os deslocamentos humanos causassem mal-estar e perplexidade (...) Os diferentes seriam síntese da sujeira autolocomotora, obstáculo à higiene, à limpeza e à ordem, três princípios fundamentais da estética do shopping, ou melhor, da

\footnotetext{
74 BELLI, Benoni. Tolerância Zero e democracia no Brasil: visões da segurança pública na década de 90. São Paulo: Perspectiva, 2004. p. 65.

${ }^{75}$ Cf. CALDEIRA, Teresa, op. cit. passim.

${ }^{76}$ CARRANO, Paulo César Rodrigues. Os jovens e a cidade: identidades e práticas culturais em Angra de tantos reis e rainhas. Rio de Janeiro: Relume Dumará, 2002. p. 60-61. A segregação fica ainda mais patente em ambientes nos quais os jovens de classe média e alta evitam deliberadamente o contato com outros jovens de camadas sócio-econômicas mais baixas. Na mancha de lazer da Vila Olímpia, em São Paulo, por exemplo, a fim de manter do lado de fora jovens pobres, "baianos", seres contaminadores que curtem o mesmo tipo de música e desejam se igualar aos de status social superior, os donos das baladas fechadas utilizam diversos artifícios, como preços abusivos, exigência de determinado tipo de vestimenta para ingressar na casa, listas VIPs de pessoas "bem selecionadas" e privilégios obtidos somente por meio da internet (BORGES, Ana Luiza Mendes; AZEVEDO, Clara de Assunção. A mancha de lazer na Vila Olímpia. In: MAGNANI, José Guilherme Cantor; MANTESE, Bruna (Org.). Jovens na Metrópole: etnografias de lazer, encontro e sociabilidade. São Paulo: Editora Terceiro Nome, 2007. p. 98 et seq.)
} 
configuração urbana do capitalismo tardio (...) Esses deslocamentos, essa impureza autolocomotora dá medo (...) Essa quebra do encanto proporcionado pelo projeto estético consumista causa profundo mal-estar, causa angústia, causa apreensão (...) É como se a ilusão momentânea produzida pelo estar no shopping se quebrasse quando aquela pobreza entrou de roldão. ${ }^{77}$

A política atuarial forma um grande cordão sanitário que filtra, exclui defensivamente e marca espacialmente uma determinada subclasse, apesar da heterogeneidade da cidade tornar muito difícil isolar populações diferentes, tanto em termos de habitação urbana como também pela necessidade de transmitir a dispersão urbana por razões de trabalho e lazer. Cria-se um sistema de barreiras para prevenir ou administrar o crime, por meio da privatização do espaço público, fortificações externas, patrulhas de segurança, câmeras de vigilância, planejamento urbano, gradeamento de propriedades privadas e bloqueio de áreas para evitar o acesso fácil, inclusive elevando-se o custo do transporte público. $\mathrm{O}$ cordão sanitário atuarial, em última análise, serve para tornar a vida mais tolerável para os vencedores e transformar os perdedores em bodes expiatórios.

A polícia atuarial, por sua vez, preocupa-se com a remoção de incertezas, utilizando circuitos fechados de televisão e controlando minuciosamente os comportamentos antisociais em geral, criminosos ou não. ${ }^{78}$ As minorias raciais e étnicas são desproporcional e seletivamente vitimizadas pelo abuso policial $^{79}$, formando a clientela preferencial do sistema. Nas Operações Verão do Rio, por exemplo, os policiais param suspeitos e os impedem de chegar à Zona Sul por falta de documentos, de camisa ou por contar uma história que não convenceu os policiais. Os suspeitos, segundo um dos policiais, "mostram que têm problemas com a Polícia no olhar, e são geralmente banhistas que vêm de muito longe". 80

\footnotetext{
${ }^{77}$ No dia 4 de agosto de 2000, o Movimento dos Trabalhadores Sem-Teto (MTST), integrado por moradores de ocupações na Baixada Fluminense e na Zona Oeste, "invadiu" o shopping Rio Sul. Tratava-se, na realidade, de uma invasão estética, já que o objetivo era passear no shopping, e não tomá-lo. As autoridades da Segurança Pública no Rio de Janeiro souberam da iniciativa, pararam os ônibus em que estavam os semteto e os impediu de prosseguir por falta de documentos. Os sem-teto seguiram em ônibus comuns e encontraram o shopping guardado por 40 policiais. A presença dos sem-teto no shopping incomodou e assustou muitos de seus frequentadores habituais e foi apontada como um fator que atrapalha o comércio (BATISTA, Vera Malaguti. O medo na cidade do Rio de Janeiro: dois tempos de uma história. Rio de Janeiro: Revan, 2003. p. 107-109).

${ }^{78}$ YOUNG, Jock, op. cit. p. 38 et seq.

${ }^{79}$ BATISTA, Vera Malaguti. Intolerância dez, ou a propaganda é a alma do negócio. Discursos sediciosos: crime, direito e sociedade. Rio de Janeiro, v. 2, n. 4, 1997 . p. 217.

${ }^{80}$ CUNHA, Olívia M. G., op. cit. p. 92.
} 


\subsection{Arrastões, espaço público e tolerância zero}

A repressão aos arrastões que ocorrem nas praias, nas saídas de estádios de futebol e de bailes funk, para ser compreendida, deve ser devidamente articulada às chamadas políticas urbanas de tolerância zero, inspiradas na teoria das janelas quebradas, divulgada, por sua vez, em um artigo de James Q. Wilson e George Kelling, em 1982. Segundo tal teoria, o crime mais grave é resultado de um continuum de pequenas desordens e incivilidades, que, se toleradas, geram a sensação de abandono do espaço público e, consequentemente, de anomia. Se janelas quebradas em um edifício não são consertadas, as pessoas que gostam de quebrar janelas terão a impressão de que ninguém se importa com seus atos de incivilidade e continuarão a quebrar mais janelas.

Para evitar que a sensação de impunidade em relação às infrações menos graves crie um ambiente de desamparo e anomia, as políticas de tolerância zero atribuem ao Poder Público o dever de punir com rigor os distúrbios contra a "qualidade de vida", pequenas desordens e incivilidades do cotidiano praticadas no espaço público, como atos de vandalismo, brigas entre vizinhos, pichações, violações de leis de trânsito e de toques de recolher, etc. ${ }^{81}$ Os primeiros efeitos desta política republicana em Nova York fizeram com que em um só trimestre de 1994 subisse em 38\% o número de prisões de mendigos, bêbados e limpadores de pára-brisas. Promoveu-se um "colossal arrastão punitivo" contra a prostituição, a mendicância, as festas de rua, guardadores de carro, baderneiros em geral, pessoas que pulavam as catracas do metrô e que faziam barulho excessivo na rua. ${ }^{82}$

Ao invés de investir em políticas públicas de combate à pobreza e de revalorização de um espaço público democrático em que a integração comunitária seja estimulada, as políticas de tolerância zero optam por um caminho excessivamente repressivo, ainda que não tenham apresentado resultados convincentes que justifiquem sua adoção. A necessidade de se estar atento em um espaço público, democrático, de "convivência de identidades heterogêneas que compartilham igualdades de direito" não corrobora o

\footnotetext{
${ }^{81}$ BELLI, Benoni, op. cit. p. 64; SHECAIRA, Sérgio Salomão. Tolerância Zero. In: Revista Internacional de Direito e Cidadania. n. 5, v. 2, 2009. p. 166 et seq.; BATISTA, Vera Malaguti. Intolerância dez, ou a propaganda é a alma do negócio. In: Discursos sediciosos: crime, direito e sociedade. Rio de Janeiro, v. 2, n. 4, 1997. p. 219.

${ }^{82}$ BATISTA, Vera Malaguti. O medo na cidade do Rio de Janeiro: dois tempos de uma história. Rio de Janeiro: Revan, 2003. p. 98.
} 
discurso daqueles que identificam nas ruas da cidade "apenas a presença da violência, do crime e da morte eminente".

Os toques de recolher para menores a partir de determinado período da noite, por exemplo, parecem pressupor que a violência está condicionada a horários, ou que se reduziriam a ingestão de drogas e bebidas alcoólicas forçando o recolhimento dos jovens. Essas iniciativas, na realidade, "instauram um movimento de legalidade heterônoma que, simultaneamente, se afasta da orientação democrática de estímulo à cidadania responsável e desconfia da autonomia e capacidade das escolhas dos jovens na cidade". ${ }^{8}$

As políticas de tolerância zero, assim, reprimem seletivamente aqueles acusados de “privatizar”, degradar o espaço público e gerar a sensação de insegurança que fez com que as camadas médias e altas da população se enclausurassem em seus enclaves. Os principais alvos da teoria das janelas quebradas são os excluídos da economia capitalista, os nãoconsumidores, o sub-proletariado que vive do mercado informal e representa uma ameaça, aqueles que antes eram objeto do assistencialismo ou de políticas reabilitadoras e que hoje são considerados irrecuperáveis e, desse modo, devem ser de alguma forma neutralizados.

A luta contra a insegurança e a "perturbação da ordem pública", pela restauração do sentimento de ordem, pela aplicação da lei ao pé da letra e pela moralização do comportamento das classes inferiores é um pretexto para uma política de limpeza de classe dos espaços públicos da cidade. Mais do que restabelecer a qualidade de vida dos novaiorquinos, as políticas de tolerância zero buscam restabelecer a qualidade de vida dos novaiorquinos de classe média e alta, as que ainda votam, pois estas supostamente sabem se comportar em público. O "policiamento intensivo" visa grupos e não delinquentes isoladamente.

As suspeitas são baseadas no vestuário, no comportamento, no modo de ser e, principalmente, na cor da pele. Muitas detenções são efetuadas sem motivo e as queixas contra abuso policial aumentam consideravelmente entre a população negra, que perde em "qualidade de vida" e segurança, enquanto os nova-iorquinos brancos se consideram beneficiários e louvam essa política repressiva. ${ }^{84}$

Verifica-se que a relação das elites com o espaço público é bastante ambígua. Por um lado, há aversão ao convívio plural, democrático e heterogêneo da rua moderna e resistência quanto a se submeter a regras cívicas básicas de convivência que afrontem seus

${ }^{83}$ CARRANO, Paulo César Rodrigues, op. cit. p. 48.

${ }^{84}$ BELLI, Benoni, op. cit. p. 68; WACQUANT, Loïc. A globalização da "Tolerância Zero". In: Discursos Sediciosos: crime, direito e sociedade, v. 9/10. Rio de Janeiro: Freitas Bastos, 2000. p. 111-112, 116-117. 
privilégios de classe. A forma como os jovens de classe alta lidam com as regras de trânsito e as convenções dos condomínios fechados é emblemática. ${ }^{85}$ Por outro lado, notase, por trás das demandas por tolerância zero, uma vontade das camadas altas e médias de reconquistar o espaço público das ruas, em uma atitude nostálgica. A retórica militar da "guerra" ao crime e da "reconquista" do espaço público é o

\begin{abstract}
instrumento de legitimação da gestão policial e judiciária da pobreza que incomoda- a que se vê, a que causa incidentes e problemas no espaço público, alimentando assim um sentimento difuso de insegurança ou mesmo simplesmente de tenaz incômodo e de inconveniência. Facilitando o amálgama com a imigração, os delinquentes (reais ou imaginários), os sem-teto, os mendigos e outros marginais são assimilados como invasores estrangeiros, elementos alógenos que devem ser expurgados do corpo social, o que acaba trazendo resultados eleitorais positivos nos países varridos por fortes correntes xenófobas. ${ }^{86}$
\end{abstract}

O arrastão de Ipanema promovido por "invasores" teve um grande impacto, entre outros motivos, porque aconteceu em um local onde não era esperado que acontecesse, ou seja, em uma área nobre da cidade do Rio de Janeiro, não degradada, ocupada por membros das classes abastadas, em plena luz do dia. A reconquista do espaço público pelas classes médias e altas muitas vezes vem dissociada da busca por um espaço heterogêneo e democrático. O que se observa nas políticas de valorização das regiões centrais das metrópoles é muito mais um esforço higienista em varrer a pobreza perigosa para fora dos espaços públicos. O centro é encarado como um lugar estratégico e alvo de especulação imobiliária. A iniciativa privada pressiona o Poder Público para que os espaços públicos centrais, degradados por mendigos, prostitutas e toxicômanos, sejam resgatados e destinados, por meio de incentivos fiscais, a projetos comerciais e residenciais de classe média e alta, revalorizando-se.

Por um lado, observa-se a repressão a movimentos sociais de sem-tetos, a construção de rampas antimendigo, a diminuição do número de banheiros públicos, a vedação do acesso à água potável, a proibição de bebidas alcoólicas, o policiamento ostensivo, o cercamento de parques e uma série de outras medidas que visam a tornar os espaços públicos centrais inóspitos para membros das classes baixas. Por outro lado, observa-se nesses espaços a instalação de bares, cafés, salas de concerto e o fomento de

\footnotetext{
${ }^{85}$ CALDEIRA, Teresa, op. cit. p. 275 et seq., 321-323.

${ }^{86}$ WACQUANT, Loïc, op. cit. p. 113.
} 
eventos culturais que tenham como público-alvo pessoas de classes médias e altas. ${ }^{87}$ Paradoxalmente, se invoca a "privatização" do espaço público por pobres para legitimar sua "privatização" por ricos.

Em uma visão limitada a uma perspectiva sociológica, surge inevitavelmente a impressão de que as pessoas, e mais precisamente os jovens de classes sociais diferentes, estão isolados e fragmentados na metrópole, uma vez que a rua, o espaço de encontro, foi abandonada. Porém, adotada uma perspectiva de perto e de dentro, própria da etnografia, fenômenos não percebidos dentro da perspectiva macro chamam a atenção. A dicotomia público-privado é muito pobre e pouco segura para explicar a metrópole pós-moderna. Por outro lado, a rua não pode ser considerada o único espaço público de convivência da cidade. A partir dessas considerações é que Magnani formula novas categorias de sociabilidade na cidade, como as de pedaço. ${ }^{88}$

Não se pode mais pensar, como as políticas de tolerância zero fazem, a dicotomia público-privado por meio da dicotomia rua-casa. O pedaço é justamente o espaço territorial demarcado que se torna "ponto de referência para distinguir determinado grupo de frequentadores como pertencentes a uma rede de relações". Trata-se do "espaço intermediário entre o privado (a casa) e o público, onde se desenvolve uma sociabilidade básica, mais ampla que a fundada nos laços familiares, porém mais densa, significativa e estável que as relações formais e individualizadas impostas pela sociedade". ${ }^{89}$ Em alguns pedaços do bairro da Vila Olímpia, em São Paulo, colocar o som do carro no volume máximo ou passar com o carro cantando pneu, por exemplo, é uma forma de se comunicar, reconhecer iguais, transmitir mensagens e valores, estabelecer relações, conferir status, etc. ${ }^{90}$ A interrupção do trânsito, longe de significar um transtorno, representa algo positivo, pois possibilita um tempo maior para a paquera. ${ }^{91}$

\subsection{Arrastões e subcultura delinquente}

O arrastão pode ser melhor compreendido se devidamente contextualizado no quadro teórico da subcultura delinquente. Os jovens participantes, em sua maioria, provêm

\footnotetext{
${ }^{87}$ FRÚGOLI, Heitor. Centralidade em São Paulo. São Paulo: Editora Cortez/Edusp, 2000. p 24-25.

${ }^{88}$ MAGNANI, José Guilherme Cantor. De perto e de dentro: notas para uma antropologia urbana. In: $R B C S$, vol. 17, n. 49 , junho 2002. p.14 et seq.

${ }^{89}$ Ibid, p. 21.

${ }^{90}$ BORGES, Ana Luiza Mendes; AZEVEDO, Clara de Assunção, op. cit. p. 92-95, 102-103, 109-111.

${ }^{91}$ Cf. CARRANO, Paulo César Rodrigues, op. cit. p. 47.
} 
de segmentos desfavorecidos da população, os quais sofrem com a discriminação, o desemprego, o sub-emprego, a falência do sistema educacional e a falta de perspectivas profissionais em uma sociedade consumista. Não foi à toa que o comportamento dos participantes do arrastão foi comparado pela mídia ao dos "rebeldes sem causa", da “juventude transviada" dos anos 50.

No final dos anos 50, nos EUA, a estrutura social impedia alguns jovens de estratos inferiores de concretizar, pelo menos de forma lícita, as metas sociais impostas pela disseminada ética do sucesso, característica do American Dream. Formaram-se, assim, subculturas criminais como reação ao sentimento de frustração e humilhação. O grupo subcultural possui um padrão de valores próprio e aceita normalmente condutas como jogos de azar, algazarras nas ruas, obscenidades e vandalismo. Por outro lado, em grande parte, a subcultura reproduz alguns valores contidos na sociedade tradicional, porém com um sinal invertido. A lealdade, por exemplo, é valorizada e o traidor é considerado arquiinimigo do grupo. Nisso difere da juventude contracultural, que faz uma "negação mais compreensiva e articulada da sociedade" ${ }^{92}$.

Se, por uma lado, "funkeiros" rechaçam dogmas da cultura hegemônica, como o culto ao trabalho, por outro acolhem alguns valores da sociedade mais ampla, como o consumismo, o que fica evidente em algumas letras de funk que exaltam marcas de roupas e no gosto dos "funkeiros" em frequentar shopping centers. A percepção de que não realizarão as metas sociais no mundo do trabalho faz com que desloquem suas expectativas para o mundo do consumo, inclusive o do consumo cultural. Não há entre eles diretamente, assim como não havia entre a "juventude transviada dos anos 50", nenhum projeto de transformação política, como o dos jovens contraculturais dos anos 60, o que não significa que seus atos não tenham uma conotação política importante, conforme será analisado no capítulo $5 .^{93}$

\footnotetext{
${ }^{92}$ SHECAIRA, Sérgio Salomão. Criminologia. São Paulo: Editora Revista dos Tribunais, 2004. p. 245 et seq. A comparação entre os jovens participantes do arrastão e a juventude transviada da década de 50 , que participava de conflitos colegiais e quebra-quebras de bondes, por causa de aumentos, e de cinemas, por ocasião da chegada dos primeiros filmes de rock'n'roll, também é feita pelo urbanista Manoel Ribeiro (Apud VENTURA, Zuenir. Cidade partida. Rio de Janeiro: Companhia das Letras, 1994. p. 96-97). São conhecidos os versos de Rita Lee que afirmam que "roqueiro brasileiro sempre teve cara de bandido".

${ }^{93}$ Enquanto a juventude de classe média pintou os seus rostos em 1992 para pedir o impeachment do Presidente Collor e foi saudada por isso, os funkeiros foram tratados pela mídia como rebeldes sem causa que exultavam com a sádica possibilidade de ver os moradores da Zona Sul em pânico nas praias (ESSINGER, Silvio, op. cit. p. 126).
} 
Os grupos subculturais ainda têm como referência os valores da sociedade mais ampla. Atacam justamente o que é valorizado pela sociedade, como a paz, o silêncio, a tranquilidade, a limpeza e a ordem. De acordo com Shecaira,

\begin{abstract}
As condutas dos delinquentes são corretas, conforme os padrões da subcultura dominante, exatamente por serem contrárias às normas da cultura mais gerais (...) Algumas condutas que significariam degradação e desonra em um grupo convencional servem para engrandecer e elevar o prestígio pessoal e o status de um membro de um grupo delinquente. Este negativismo não tem um grande raio de alcance. É apenas um hedonismo com interesse de mostrar o rechaço deliberado dos valores correlativos da classe dominante. ${ }^{94}$
\end{abstract}

Muitos pichadores afirmam protestar através da pichação, mas poucos sabem dizer claramente contra o quê. Se essa forma de protesto serve para mostrar como as coisas estão erradas, também se torna uma maneira de justificar as ações dos pichadores, que alegam ser um mal menor e um bode expiatório em um país em que todos praticam crimes. ${ }^{95}$ As mensagens políticas nas pichações da época da ditadura militar deram lugar a garranchos indecifráveis para quem não faz parte desta subcultura. ${ }^{96}$ É própria, aliás, de toda subcultura a existência de gírias que geram o reconhecimento mútuo e funcionam como barreira para quem é de fora. Em uma análise superficial, os pichadores teriam supostamente apenas o objetivo de sujar a cidade. Um olhar etnográfico mais apurado, porém, revela que eles possuem códigos de conduta, como, por exemplo, o de nunca pichar em cima da pichação alheia ou residências que contribuem com entidades assistenciais.

Além da polaridade negativa, os atos subculturais são caracterizados pelo nãoutilitarismo e pela maliciosidade ínsita à conduta. ${ }^{97}$ Ao sair dos bailes e estádios promovendo arrastões, quebra-quebras e depredações, a intenção não é de ganho patrimonial ou qualquer outra de cunho utilitário, conforme já foi analisado. O que motiva os atos de vandalismo parece ser muito mais o gosto pela "zoação", a aventura, a adrenalina de se expor ao perigo. Por outro lado, há um prazer em causar o desconforto alheio, como fica patente no depoimento de um dos participantes do arrastão do Arpoador,

\footnotetext{
${ }^{94}$ SHECAIRA, Sérgio Salomão. Criminologia. São Paulo: Editora Revista dos Tribunais, 2004. p. 253.

95 PEREIRA, Alexandre Barbosa. De rolê pela cidade: os pixadores em São Paulo. 2005. Dissertação (Mestrado)-Faculdade de Filosofia, Letras e Ciências Humanas, Universidade de São Paulo, São Paulo, 2005. p. 112 .

${ }^{96}$ CARMO, Paulo Sérgio do. Culturas da rebeldia: a juventude em questão. São Paulo: Editora SENAC, 2001. p. 140; SHECAIRA, Sérgio Salomão, op. cit. p. 258-259.

${ }^{97}$ COHEN, Albert K. Delinquent boys: the culture of the gang. Illinois: The Free Press, 1955. p. 25 et seq.
} 
de 16 anos, que admitiu ter feito aquilo "de sacanagem, pra arrepiar os bacanas, mostrar que a praia não é só deles". 98

Os atos subculturais só têm valor para seus autores por lhes assegurar status dentro de seu grupo subcultural e entre grupos rivais. O desafio é atingir metas proibidas e inatingíveis aos seres comuns. Quanto maior a façanha, maior o reconhecimento. Muitos adolescentes transgridem as normas não para burlar a lei, na esperança de escapar das consequências de seus atos, mas, ao contrário, para que a repressão corra atrás deles e assim os reconheça como pares dos adultos. A fase da adolescência é tradicionalmente uma fase de afirmação da personalidade e, não raras vezes, de revolta. Sob determinadas condições de insegurança e de ausência de crenças morais, esta revolta induz algumas pessoas à prática de atos de vandalismo e outros crimes. Nessas condições, a delinquência poderia ser uma sólida vocação da adolescência, tanto que pouquíssimos adolescentes se tornam propriamente delinquentes. ${ }^{99}$

Com efeito, Matza destaca como principais formas de tradições rebeldes juvenis a delinquência, a boemia e o radicalismo:

No caso da delinquência, um dos aspectos mais importantes é o culto da proeza. Seus adeptos buscam incansavelmente excitações, sensações, emoções, estabelecendo como estilo de vida apropriado à aventura, em contraponto aos padrões rotineiros de comportamento. Infringir as leis é o que torna, muitas vezes, uma atividade atraente. Além disso, a proeza é também realizada com o intuito de ter acesso fácil à riqueza e ao sucesso rápido expressando uma rejeição ao metodismo e à rotina implicados na trajetória da escola ao trabalho. $\mathrm{O}$ dinheiro é valorizado pelo que ele pode comprar, ou seja, o delinquente usa o dinheiro de forma perdulária, em gestos de prodigalidade e em consumo conspícuo. Outro aspecto próprio da delinquência é o comportamento violento, associado à masculinidade e ao ethos guerreiro. A delinquência é definida pelo código legal e envolve dois aspectos: furtos, assaltos e vandalismo, e a adoção de práticas consideradas inadequadas como o fumo, a vagabundagem, jogo, bebida, liberdade sexual. ${ }^{100}$

Estas observações podem ser aplicadas, sem grandes dificuldades, aos pichadores, um grupo subcultural criminalizado, que apresenta o gosto pela adrenalina, o alcance de status dentro do grupo por meio de proezas, o rechaço aos policiais e à sociedade como um todo, bem como o flerte com a criminalidade. Entre os pichadores, a criação dos riscos

\footnotetext{
${ }^{98}$ VENTURA, Zuenir, op. cit. p. 63; CARMO, Paulo Sérgio do, op. cit. p. 168.

${ }^{99}$ SHECAIRA, Sérgio Salomão. Criminologia. São Paulo: Editora Revista dos Tribunais, 2004. p. 250 et seq. ${ }^{100}$ QUEIROZ, Tereza Correia da N. Culturas juvenis, contestação social e cidadania: a voz ativa do hip hop. In: ALVIM, Rosilene; JUNIOR, Edísio Ferreira; QUEIROZ, Tereza (Org.). In: (Re)construções da juventude: cultura e representações contemporâneas. João Pessoa: Editora Universitária-PPGS/UFPB, 2004. p. $19-20$.
} 
produz excitação. Aquele que pratica a maior proeza e enfrenta os maiores desafios, como pichar em locais difíceis, recebe o maior reconhecimento dentro do grupo. Desafiar a polícia é apontado por eles como um grande fator de motivação para a prática da pichação. Ao tratar os pichadores de maneira violenta em suas abordagens, a polícia acaba por tornar esta opção pela criminalidade ainda mais interessante.

Entretanto, ao invés da noção de delinquência, o melhor termo para analisar os pichadores seria o da transgressão, uma vez que há a valorização de uma postura marginal presente em diversos momentos de seu cotidiano e não apenas no ato de atentar contra a propriedade alheia: ao passar debaixo da catraca para não pagar o ônibus, no consumo de drogas, em furtos ou em ações mais graves, como o narcotráfico e o assalto à mão armada. $^{101}$

Assim como os pichadores, as galeras funk não empreendem o enriquecimento de seus membros através de práticas ilícitas. Se os membros das galeras praticam atividades ilícitas, o fazem de maneira transitória e intermitente, mais próxima da "deriva" da qual saem com o crescimento, do que da delinquência assumida e desejada como meio de vida. $^{102}$

\footnotetext{
${ }^{101}$ PEREIRA, Alexandre Barbosa, op. cit. p. 110-112. A pesquisa de Minayo et alii constatou que a pichação é um lazer primordialmente masculino. Na pesquisa domiciliar uma proporção maior de jovens de classe média do que de classe popular afirmou participar desses grupos $(4,1 \%$ contra $2 \%$, respectivamente). Esse dado é confirmado em outra questão em que $4,6 \%$ dos jovens de classe média contra $3 \%$ de classe popular disseram que se reúnem com sua turma para pichar muros e patrimônios. A pichação não se reduz a "funkeiros", mas vários deles explicitaram que apreciam pichar os muros da cidade e fizeram associação entre as duas atividades. Da mesma forma que nos bailes, grupos rivalizam a capacidade de transgredir, de assumir riscos e de acumular assinaturas. Consideram que pichar longe do bairro, em lugares bem altos e arriscados confere fama. Quando apanhados, costumam sofrer experiências de violência tanto por parte da polícia como de seguranças particulares (MINAYO, Maria Cecília de Souza et alii. Fala, galera: juventude, violência e cidadania no Rio de Janeiro. Rio de Janeiro: Garamond, 1999. p. 59).

${ }^{102}$ ZALUAR, Alba. Gangues, Galeras e Quadrilhas: globalização, juventude e violência. In: VIANNA, Hermano (Org.). Galeras cariocas: territórios de conflitos e encontros culturais. Rio de Janeiro: Editora da UFRJ, 1997. p. 48-49. Para David Matza, a delinquência juvenil teria um caráter intermitente e transitório, já que "o compromisso dos jovens com as 'subculturas' que requerem o desrespeito à lei não é nem uma poderosa coação nem uma obrigação" (Apud Ibid. p. 53-54). De acordo com Alexandre Pereira, o grande motivo que faz com que os jovens parem de pichar "é o aumento de determinadas responsabilidades, o que para muitos significa o ingresso na vida adulta. Existem os que param por pressão das namoradas, ou quando se tornam pais e precisam trabalhar para sustentar os filhos ou porque têm que ajudar a mãe com as despesas de casa. Mas há também aqueles que entram definitivamente na criminalidade e muitas vezes acabam sendo presos. Este último fator também representa a passagem para a vida adulta de alguns deles que já alcançaram a maioridade penal (...). Podem ainda surgir outros interesses que façam com que a pixação (sic) perca um pouco o sentido para alguns destes jovens. O empenho em uma outra forma de manifestação cultural é um deles" (PEREIRA, Alexandre Barbosa, op. cit. p. 114).
} 


\subsection{A relação entre as galeras funk e as quadrilhas}

A repercussão dos arrastões na Zona Sul do Rio de Janeiro chamou a atenção da grande mídia para a existência das galeras e dos bailes funk de subúrbio, onde eram comuns as brigas e as depredações na hora da saída. Estigmatizadas, as galeras foram associadas a gangues ou quadrilhas de criminosos. ${ }^{103}$ Há, porém, diferenças fundamentais entre elas. Para Sánchez-Jankowski, as gangues são associações pouco estruturadas de indivíduos, quase privadas e quase secretas, pois a maior parte das informações sobre suas atividades permanece restrita ao grupo. Eles possuem uma liderança e códigos de conduta bem definidos, mas não uma burocracia, e praticam atos ilegais visando à acumulação de recursos. ${ }^{104}$ Podem estar relacionadas ou não com as redes formais do narcotráfico e são independentes do fenômeno funk.

Já a galera é uma rede menos densa, formada por laços de amizade e por gostos afins. ${ }^{105}$ Ao contrário das gangues, estão estruturadas fundamentalmente sobre atividades ligadas ao lazer, como ir à praia, dançar, cantar, beber, namorar, etc. ${ }^{106}$ As galeras são formadas em ruas, certos pontos referenciais dentro da favela ou pela afinidade de jovens e adolescentes que brincam/jogam/conversam perto de um campo de futebol, um bar, um time/torcida de futebol ou da antiga sede da equipe local/associação de moradores do bairro. ${ }^{107}$ Todas têm um código próprio, que é do conhecimento apenas dos participantes.

\footnotetext{
${ }^{103}$ A expressão "gangue" é, em geral, evitada pelos chefes de galeras por trazer a conotação pejorativa de ligação com o narcotráfico (GUIMARÃES, Eloísa. Escola, Galeras e Narcotráfico. Rio de Janeiro: Editora UFRJ, 2003. p.79-80). Por outro lado, o DJ Marlboro relata que a associação do termo "galera" a pancadaria, fez com que ele passasse a adotar o termo "bonde" como sinônimo pra aglomeração de pessoas (MACEDO, Suzana. DJ Marlboro na terra do funk- Bailes, bondes, galeras e MCs. Rio de Janeiro: Dantes Livraria e Editora, 2003. p. 114). Ocorre que a palavra "bonde" também ficou estigmatizada, associada aos "bondes sinistros" dos traficantes. Hoje, a palavra "galera" não designa apenas os grupos que se reúnem nos bailes, mas também uma multidão (HERSCHAMANN, Micael, op. cit. p. 78).

${ }^{104}$ Apud HERSCHMANN, Micael, op. cit. p. 48-49. Neste ponto, as gangues assemelham-se às quadrilhas, que adotam modelos empresariais de gestão de negócios e cujo interesse primordial é o lucro imediato decorrente do controle exclusivo do tráfico de drogas nas áreas ocupadas (GUIMARÃES, Eloísa, op. cit. p. 91). Além da busca do enriquecimento rápido através de atividades ilegais e empresariais, outros pontos de semelhança entre as gangues e as quadrilhas são o fascínio pela arma de fogo, o ethos de virilidade, o machismo, o poder imposto pelo terror aos moradores do local onde atuam, os valores militares e quase aristocráticos (ZALUAR, Alba. Gangues, Galeras e Quadrilhas: globalização, juventude e violência. In: VIANNA, Hermano (Org.). Galeras cariocas: territórios de conflitos e encontros culturais. Rio de Janeiro: Editora da UFRJ, 1997. p. 45-46). Esse conceito de gangue, contudo, difere do conceito tradicional, importado da teoria da subcultura delinquente, que considera o não utilitarismo de suas ações uma de suas características centrais.

${ }^{105}$ ARCE, José Manuel Valenzuela, op. cit. p. 99-100.

${ }^{106}$ HERSCHMANN, Micael, op. cit. p. 49.

${ }^{107}$ CUNHA, Olívia M. G., op. cit. p. 118.
} 
Há uma rede de solidariedade bastante valorizada, sendo comum que um membro ajude outro dando apoio moral ou material quando necessário.

Para ingressar na galera, pode haver a necessidade de o novato "pagar o bicho", ou seja, fornecer determinada quantidade de droga. ${ }^{108}$ A maioria dos jovens afirma que basta $\mathrm{o}$ "candidato" fazer parte daquela comunidade ou de uma comunidade "amiga" que ele geralmente é admitido, mas vários fatores podem determinar a inclusão de um jovem numa galera: o nível de prestígio do indivíduo junto a outras galeras e ao público feminino de modo geral; o grau de parentesco com algum membro desta galera; se não integrou grupos rivais; se sabe se expressar bem; a maneira de se vestir; se é forte e destemido o bastante para atuar num embate; se tem "disposição" para brigar e até matar. A briga parece ocupar um espaço central na existência e organização da galera. A utilização da violência é, portanto, uma condição de admissão, pois é uma questão de sobrevivência física.

A maioria dos integrantes das galeras é do sexo masculino. As meninas parecem definir sua posição no grupo por parentesco e afinidade ou por "ligação amorosa" com algum membro do grupo. Apesar de as galeras terem as brigas com outros grupos como referência fundamental para sua organização, outros interesses parecem motivar o ingresso de jovens nesses grupos, como o desejo de serem prestigiados localmente (e mesmo em outros bairros) e o medo de saírem de seus bairros e transitarem sozinhos pela cidade, principalmente por praias, bailes de clube e estádios de futebol, onde podem encontrar "alemães" (inimigos) ou a polícia. ${ }^{109}$

As galeras são influenciadas pela tradição dos movimentos juvenis que se formaram em diversos países no decorrer do século XX, como o dos apaches do subúrbio de Paris, das gangues estado-unidenses, dos hooligans ingleses e das "bandas" mexicanas. Apesar de cada um destes grupos de jovens transgressores ter configurações particulares, todos apresentam características comuns, como as brigas com grupos rivais como eixo de organização, o "estar sempre juntos" e a perambulação por espaços públicos, ocasião em que ocorrem os roubos, saques, agressões ou o simples desfile em atitudes ameaçadoras.

O território é a base e o princípio de constituição do grupo. Deve ser controlado e defendido contra a invasão de grupos rivais que moram em áreas adjacentes, os “alemães”,

\footnotetext{
${ }^{108}$ GUIMARÃES, Eloísa, op. cit. p. 81-83.

109 HERSCHMANN, Micael, op. cit. p. 164 et seq; GUIMARÃES, Eloísa, op. cit. p. 90-91, 101; CECCHETTO, Fátima, op. cit. p. 110. Na pesquisa domiciliar realizada por Minayo et alii, $11 \%$ dos rapazes e moças das camadas populares afirmam participar de galeras de funk, contra 5,7\% dos jovens de classe média. Os motivos alegados para a frequência aos bailes, em grupo, são a proteção em caso de agressão de outras turmas (MINAYO, Maria Cecília de Souza et alii, op. cit. p. 56).
} 
ou até de representantes de instituições da sociedade mais ampla. A consciência de pertencimento ao território tende a crescer com os combates. Cada grupo luta para ampliar as fronteiras, apropriando-se de áreas públicas de maior visibilidade, no interior ou nos limites da área de moradia, como praças e quadras de esportes, os "pedaços". Para controlar sua área, as galeras criam uma "aura de terror", que causa fascínio, glória, sedução e uma sensação de poder. ${ }^{110}$

Esses processos se assemelham às guerras entre quadrilhas rivais na disputa pelos pontos do tráfico e às formas desenvolvidas pelo tráfico para defesa e proteção do próprio território e dos moradores locais. As galeras sofrem influência das gangues e das quadrilhas de traficantes tanto na sua organização quanto nas suas práticas e valores, tais como a defesa da honra masculina, o domínio e a proteção dos territórios conquistados, a lealdade irrestrita ao grupo, a obediência ao chefe, o respeito incondicional ao código moral próprio estabelecido, o uso da força física e das armas para vingar o espaço invadido e as regras violadas, etc.

A delimitação dos territórios pelas galeras e pelas quadrilhas superpõe-se à demarcação "oficial” dos espaços da cidade, instaurando fronteiras nem sempre visíveis, mas objetivas e tacitamente acordadas. O fato de um elemento de um dos grupos pisar no território do outro é suficiente para desencadear uma briga, o que pode explicar a distribuição da área dos clubes onde são realizados os bailes funk entre as galeras e os “arrastões” ocorridos nas praias da Zona Sul, em 1992 e $1993 .{ }^{111}$ No episódio do arrastão do Arpoador, jornalistas deduziram apressadamente que, por trás da divisão territorial imaginária da praia entre as galeras, havia a lógica da divisão territorial do tráfico e a extensão de seu domínio para as areias. Cada ponto corresponderia a bocas de fumo, que, por sua vez, se filiariam a determinadas favelas ou bairros. Assim, as galeras rivais de Vigário Geral e Parada de Lucas supostamente representavam, respectivamente, as facções rivais Comando Vermelho e Terceiro Comando. ${ }^{112}$

\footnotetext{
${ }^{110}$ GUIMARÃES, Eloísa, op. cit. p. 99 et seq.. Cf. CECCHETTO, Fátima, op. cit. p. 97-98.

${ }^{111}$ GUIMARÃES, Eloísa, op. cit. p. 86 et seq.; CECCHETTO, Fátima, op. cit. p. 117. A área é vista pelos membros das quadrilhas como extensão do narcisismo masculino, de maneira que, assim como um homem não pode deixar provocações ou ofensas sem respostas, a inversão do espaço é interpretada como tentativa de emasculação. Essa lógica da guerra provocada pelas pequenas feridas no orgulho é também a base para a formação da galera, que junta os jovens de um mesmo bairro em atividades recreativas, principalmente o baile funk, consolidado no cenário musical carioca no final da década de 70, quando as quadrilhas começavam a exercer o domínio territorial das favelas (ZALUAR, Alba, op. cit. p. 47-48).

${ }^{112}$ Para uma análise da divisão territorial da praia entre as galeras e como esta era determinante na distribuição da frequência das pessoas ao longo da areia, cf. CUNHA, Olívia M. G., op. cit. p. 108-109.
} 
Esse argumento foi utilizado para legitimar a proibição dos bailes funk de comunidade, aqueles promovidos nos morros e favelas dominados por traficantes. Não atentaram, porém, talvez por má fé, talvez por simples ignorância, que os bailes de comunidade eram os mais pacíficos da cidade. Isto decorria de uma maior proximidade da convivência local e do fato de serem promovidos em territórios não neutros, ou seja, em comunidades controladas por uma ou outra facção criminosa. $\mathrm{O}$ baile de comunidade é o "baile da união", das galeras dos "comandos amigos", cujo transporte é providenciado pelos "patrocinadores". É natural que a facção não permita confusão em sua área, pois poderia propiciar confrontos com grupos rivais do crime organizado, atrair policiais e espantar a clientela, atrapalhando o comércio de drogas. ${ }^{113}$

Além disso, uma das formas de o tráfico se legitimar como justiceiro é exatamente reprimir com violência qualquer crime ou confusão que ocorra na comunidade, garantindo a "paz" e a "ordem". O fato de não haver brigas nos bailes de comunidade é invocado, inclusive, como motivo para ser frequentado por jovens de classe média e alta da Zona Sul, além da proximidade física de alguns morros e da possibilidade do livre consumo de drogas. ${ }^{114}$ A proibição pelos donos dos morros de não armar confusão na área fazia com que as ações das galeras se deslocassem sistematicamente para a área urbanizada. ${ }^{115}$

No entanto, Flávio Negão, chefe do tráfico de Vigário Geral na época em que ocorreu o arrastão do Arpoador, ficou muito irritado porque os arrastões "queimaram a imagem" da comunidade. Chamou os jovens da galera de Vigário para uma reunião e os ameaçou até de morte para que não fizessem outros arrastões ou brigas, na favela ou "lá

Recomenda-se ainda, para a compreensão do conceito de "pórtico", zona de transição entre dois "pedaços" onde impera, de certa forma, a anomia, a leitura de MAGNANI, José Guilherme Cantor, op. cit. p. 14 et seq.

${ }^{113}$ CECCHETTO, Fátima, op. cit. p. 105, 113; DAYRELL, Juarez. A música entra em cena: o rap e o funk na socialização da juventude. Belo Horizonte: Editora UFMG, 2005. p. 128-129; CUNHA, Olívia M. G. Conversando com Ice-T: violência e criminalização do funk. In: HERSCHMANN, Micael (Org.). Abalando os anos 90: funk e hip-hop - globalização, violência e estilo cultural. Rio de Janeiro: Rocco, 1997. p. 99; GUIMARÃES, Eloísa, op. cit. p. 183; HERSCHMANN, Micael, op. cit. p. 171; CARMO, Paulo Sérgio do, op. cit. p. 220. É provável que os adolescentes das galeras busquem reproduzir em seu universo pessoal a rivalidade de organizações criminosas e é possível que os comandos se interessem em atrair pessoas para suas organizações. Mesmo assim, a associação direta dos comandos com as galeras continua soando muito mais lucrativa para os jornais do que para os traficantes. Kleber Mendonça questiona o que o crime organizado lucraria com gangues de jovens se digladiando nas praias: "Um pouco de publicidade e muita polícia revistando 'seus quadros` seria desejável?” (MENDONÇA, Kleber, op. cit. p. 276-277). As mulheres de uma galera eram ameaçadas pelos traficantes de ter a cabeça raspada caso brigassem e os homens, de serem castrados. A pena das meninas já foi aplicada e a dos meninos foi trocada por atirá-los barranco abaixo (MINAYO, Maria Cecília de Souza et alii, op. cit. p. 58-59).

${ }^{114}$ HERSCHMANN, Micael, op. cit. p. 132. Já na década de 80 era utilizada pelas equipes de som com certa frequência a estratégia de deixar que os próprios "chefes de morro" tomassem conta da segurança dos bailes, uma estratégia que se mostrou efetiva. (VIANNA, Hermano. O mundo funk carioca. 2 ed. Rio de Janeiro: Zahar, 1988. p. 87).

${ }^{115}$ GUIMAR ÃES, Eloísa, op. cit. p. 150. 
embaixo, em Copacabana". Em Parada de Lucas, Robertinho, então o chefe do tráfico, colocou os garotos em fila e chegou a quebrar a mão de alguns com palmatórias. No fim de semana seguinte, reinava a paz nas praias cariocas e a Polícia Militar atribuiu a mudança ao reforço de policiamento. ${ }^{116}$ Para desestimular a ida dos jovens à praia, o "poder paralelo" ainda forneceu alternativas de "lazer e cultura" dentro da comunidade, como piscinas, atividades esportivas e bailes. ${ }^{117}$ Mais uma vez, o controle social informal demonstrou ser muito mais efetivo do que o controle social formal.

A esse respeito, vale mencionar o seguinte Acórdão do Tribunal de Justiça do Rio de Janeiro:

\begin{abstract}
0006774-43.2002.8.19.0205 (2004.050.01502) - APELACAO
DES. PAULO CESAR SALOMAO - Julgamento: 21/09/2004 - PRIMEIRA CAMARA CRIMINAL

(...) $\mathrm{O}$ crime foi praticado por motivo fútil, desproporcional e inadequado em relação ao crime, já que a vitima teria ido a um Baile na Favela do Barbante cuja facção criminosa é rival da do acusado ("ADA" Amigos dos Amigos). Resta configurado, também, o grave sofrimento físico ou moral, em razão dos maustratos. A vitima, com 12 (doze) anos de idade, foi retirada de casa, de forma forçada, agressiva e ameaçadora, e levada para um local conhecido como "Quadra 100". Chegando lá sofreu ameaças e maus tratos (...).
\end{abstract}

Mesmo tendo a rua e os espaços públicos como base de suas atividades, as galeras articulam-se em torno de suas bases residenciais, territórios previamente controlados pelo narcotráfico. A demarcação territorial e comportamental das galeras se superpõe e se subordina, portanto, à das quadrilhas, que definem, consequentemente, as possibilidades e os limites de suas ações. ${ }^{118}$ Trata-se de dois níveis distintos mas complementares. Por um lado, o narcotráfico utiliza os grupos de jovens das galeras como instrumentos de expansão de seus negócios e de ampliação da área sob seu controle, equipando-os adequadamente para tal tarefa. Em algumas escolas, por exemplo, são as galeras que provocam os acordos entre os chefes dos morros e as instituições, como os que preveem a ausência da polícia na área. Por outro lado, há certa margem de autonomia das galeras em suas formas de ação,

\footnotetext{
${ }^{116}$ VENTURA, Zuenir, op. cit. p. 137, 201-202, 243 et seq. Assim como os guardas contratados pela Riotur, os traficantes estavam empenhados em livrar a Zona Sul desses garotos, constituindo a imagem espelhada das forças de ordem (YÚDICE, George, op. cit. p. 38). "Vistas pelos funkeiros, essas histórias os enfraquecem, na demonstração de força e poder que resultam das brigas entre galeras. Para os demais moradores, representa o perigo de mais uma vez transgredir a lei do silêncio e 'sujar` a imagem do 'bandido bom`e ‘justo` com a comunidade" (CUNHA, Olívia M. G., Bonde do mal. In: MAGGIE, Yvonne; REZENDE, Cláudia B. (Org). Raça como retórica: a construção da diferença. Rio de Janeiro: Civilização Brasileira, 2001. p. 134).

${ }_{117}$ RIBEIRO, Manoel, op. cit. p. 288.

${ }^{118}$ GUIMARÃES, Eloísa, op. cit. p. 88-89.
} 
organização e objetivos, tais como o fortalecimento do grupo, a cobrança de normas não cumpridas e de "ofensas" sofridas. ${ }^{119}$

Há diferenças importantes entre a galera e a quadrilha, no que se refere ao domínio territorial e às alianças. Se o tráfico se faz presente na comunidade como "força" e "autoridade" únicas, para as galeras a referência da comunidade traduz-se num emblema de reconhecimento. Enquanto o tráfico busca conquistar e fixar o comércio de drogas em algumas localidades, as galeras realizam essas "conquistas" na força física, mas também nas alianças firmadas com as "galeras amigas", que prescindem da apropriação física de territórios. ${ }^{120}$ A “definição comportamental de fronteiras", por outro lado, faz com que sejam admitidos na galera membros residentes em outras áreas, com base em relações de parentesco e critérios geográficos. São comuns também as alianças entre galeras de áreas diferentes para lutar contra o inimigo comum. ${ }^{121}$

As alianças e rixas entre as galeras têm antecedentes que transcendem o baile funk e podem se materializar num confronto físico fora deste ambiente, por exemplo, na saída dos estádios de futebol. As brigas podem ser motivadas por disputas por territórios, uma ofensa pessoal a um membro do grupo, uma antiga rixa local revivida ou pela adesão/solidariedade a outra galera "alemã". A rivalidade das galeras decorrente da "filiação" a facções criminosas diferentes é, portanto, apenas uma das tantas rivalidades que podem ocorrer, porém é a mais acentuada pelo discurso criminalizante da mídia e da polícia. $^{122}$

\footnotetext{
${ }^{119}$ GUIMARÃES, Eloísa, op. cit. p. 107, 110. Um dos líderes de galera de Vigário Geral afirmou que não é bandido, mas que se vê numa situação semelhante e que seu tio, dono de boca-de-fumo, fortalece a galera (CUNHA, Olívia M. G. Bonde do mal. In: MAGGIE, Yvonne; REZENDE, Cláudia B. (Org). Raça como retórica: a construção da diferença. Rio de Janeiro: Civilização Brasileira, 2001. p. 126). É um importante interlocutor, muito conhecido, o que traz benefícios e perigos. É temido, mas também procurado pelos "alemães" e sente-se protegido na favela. Diz ser necessário tomar a arma de seu pai emprestada para ir ao "asfalto" sozinho e que, assim como na vida do crime, na da galera também há a figura do X-9 (alcaguete), que informa onde ela fica, quantos membros vão ao baile etc. Quando um X-9 da galera é pego, o líder, após pedir permissão para os traficantes, tem autoridade para castigá-lo, porque eles "não se metem em negócio de baile". Por outro lado, afirma que a rivalidade do funk é através do tráfico: "Lucas e Vigário, eles sempre foram considerado alemão da gente, porque eles são Terceiro e a gente é Comando" (Ibid. p. 131 et seq.).

${ }^{120}$ CUNHA, Olívia M. G., op. cit. p. 136. Em bailes distantes da favela, componentes de várias galeras tendem a unir-se formando uma única, principalmente nos momentos em que a adscrição territorial representa força e fama (Ibid. p. 118-119). As galeras movimentam-se com maior desenvoltura na vizinhança, mas não têm uma delimitação clara de um território de atuação, podendo pertencer a vários territórios e não têm exclusivamente na violência a forma principal de demarcação de áreas de atuação nas ruas (HERSCHMANN, Micael, op. cit. p. 49).

${ }^{121}$ GUIMARÃES, Eloísa, op. cit. p. 100.

${ }^{122}$ CUNHA, Olívia M. G. Conversando com Ice-T: violência e criminalização do funk. In: HERSCHMANN, Micael (Org.). Abalando os anos 90: funk e hip-hop - globalização, violência e estilo cultural. Rio de Janeiro: Rocco, 1997. p. 103-104. Assim, a galera de Vigário Geral conhecida como Jovem Fla e composta apenas por flamenguistas, por exemplo, integrará a outra Jovem Fla, mais ampla, ao lado de possíveis
} 
Quando os "funkeiros" cantam que "o alemão vai invadir", podem estar se referindo tanto à polícia, quanto ao "mauricinho da Zona Sul" ou a uma galera rival de uma localidade próxima, que pode ou não se dizer associada a algum tipo de "comando". ${ }^{123}$ Da mesma forma, o território sobre o qual o "alemão", estrangeiro e invasor, teima em estender seu domínio, pode se referir tanto às bocas e ao tráfico de droga quanto à praia, esquina, linha de ônibus ou mesmo o baile que as galeras aliadas frequentam. A associação simplista do funk, suas gírias, símbolos e imagens, com o tráfico, contudo, é facilitada quando a ideia de "invasão" aparece ao lado do refrão que ambiguamente faz referência ao "Comando". ${ }^{24}$

Os "bondes" ou "mulões", que reúnem galeras aliadas, são em geral efêmeros, transitórios, e dizem respeito ao fortalecimento momentâneo da galera em um determinado baile, e não necessariamente a alguma ligação com os "comandos". Muitas vezes a aliança de uma galera com outra é motivada pelo desejo de vencer um festival de galeras. O "alemão" de hoje poderá ser o "sangue-bom" de amanhã e vice-versa. Inquiridos sobre como se definia uma galera ou comunidade "amiga", alguns funkeiros afirmam, primeiramente, que isso estava relacionado à organização criminosa que "geria" momentaneamente o local.

Entretanto, existem galeras inimigas que são de comunidades pertencentes a "comandos iguais" e galera aliadas cujas comunidades são tidas como rivais por pertencerem a "comandos diferentes". ${ }^{125}$ As alianças são transitórias e os líderes das galeras realizam o tempo todo novos arranjos, buscando aliados que fortaleçam e confiram prestígio ao grupo. Alguns jovens param de ir ao baile quando há alteração dos comandos, pois se recusam a começar a brigar com "amigos de baile". Quando uma galera coopera com outra de comando diferente, não é possível que exiba a fidelidade ao comando rival no baile, tem que ficar "neutra". Se o "bonde" for considerado uma ameaça pela infiltração de inimigos de outras áreas, as galeras se separam. Por outro lado, quando duas comunidades "fazem a união" de comandos, o convívio passa a ser tolerado, mas as rixas recíprocas

\footnotetext{
"alemães" oriundos de galeras funkeiras inimigas de Vigário. Se no baile esse contato é explosivo, nos dias de jogo, no Maracanã, estará sujeito à disciplina dos representantes e chefes de torcida. Os inimigos não serão mais outros funkeiros, mas outros torcedores (Id. Bonde do mal. In: MAGGIE, Yvonne; REZENDE, Cláudia B. (Org). Raça como retórica: a construção da diferença. Rio de Janeiro: Civilização Brasileira, 2001. p. 119).

${ }^{123}$ HERSCHMANN, Micael, op. cit. p. 70-71.

${ }^{124}$ CUNHA, Olívia M. G. Cinco vezes favela- um reflexão. In: ALVITO, Marcos; VELHO, Gilberto (Org.). Cidadania e Violência. Rio de Janeiro: UFRJ e FGV, 1996. p. 207.

${ }^{125}$ CECCHETTO, Fátima, op. cit. p. 106; GUIMAR ÃES, Eloísa, op. cit. p. 191-192.
} 
continuam. Alguns abandonam a galera e novos componentes se incorporam ao novo contexto.

Quando um parente ou amigo do "contexto" sofre uma "judiaria" no baile ou fora dele, aciona-se o circuito de reciprocidade negativa entre esses grupos para retribuir o dano e restituir a "honra". E assim recomeça o ciclo das rivalidades sem fim. ${ }^{126}$ O líder de uma das mais temidas galeras da cidade explicou que o que define mesmo a posição no combate são as rixas entre as galeras, algumas intermináveis, embora "uns palhaços" comprem a briga das "galeras do contexto" por acharem "bacana, meio proibido". ${ }^{127}$

\subsection{Um bonde chamado "terror": a subcultura da zoação}

Conforme visto, circular pela cidade, "ser móvel", sair do próprio bairro em explorações coletivas, contrariando a política segregacionista da imobilidade, constitui uma grande transgressão por parte dos jovens pobres, negros e suburbanos, ao mesmo tempo em que é a concretização de um estado de liberdade. Por outro lado, constitui um grande risco, tanto no sentido destes jovens vulneráveis exporem seus corpos à violência das galeras "alemãs" ao adentrarem territórios proibidos, quanto no sentido de despertarem suspeitas em virtude de sua aparência e serem confundidos com criminosos, gerando reações violentas, seja por parte da sociedade civil, como ocorre nos casos de linchamento, seja por parte da polícia. ${ }^{128}$

Mais do que um impulso autodestrutivo, estes comportamentos revelam um mecanismo de defesa destes jovens. Angelina Peralva tenta explicar o ingresso de parte da

\footnotetext{
${ }^{126}$ CECCHETTO, Fátima, op. cit. p. 109-111. Nas brigas de galeras do início dos anos 1990, o Cantagalo fazia parte do chamado "Lado B" enquanto o rival e vizinho Pavão-Pavãozinho integrava o "Lado A". A partir de um determinado momento, o Comando Vermelho decidiu que todas as favelas sob seu controle deveriam integrar somente o "Lado B", suprimindo o conflito entre as populações e fazendo valer sua proibição às brigas como norma de conduta passível de punição em caso de desobediência (VIEIRA, Thiago Braga. Proibidão de boca em boca: gritos silenciosos de uma memória subterrânea: O funk proibido como fonte para o estudo da violência armada organizada no Rio de Janeiro (1994-2002). 2009. Monografia-Centro de Filosofia e Ciências Humanas, Universidade Federal do Rio de Janeiro, Rio de Janeiro, 2009. p. 77).

${ }^{127}$ HERSCHMANN, Micael, op. cit. p. 164-166.

${ }^{128}$ CUNHA, Olívia M. G. Conversando com Ice-T: violência e criminalização do funk. In: HERSCHMANN, Micael (Org.). Abalando os anos 90: funk e hip-hop - globalização, violência e estilo cultural. Rio de Janeiro: Rocco, 1997. p. 107-108; SANSONE, Livio, op. cit. p. 180. No famoso episódio do linchamento de Olaria, por exemplo, rapazes que viajavam em um ônibus, aos gritos de "pega ladrão", foram confundidos com assaltantes e linchados em 3 de julho de 1993. A polícia e os jornais silenciaram. São recorrentes os homicídios entre jovens não-brancos, justamente os que têm o perfil estereotipado de delinquentes. $\mathrm{O}$ fato de os chacinados serem negros e estarem vestidos no estilo adotado pelos jovens moradores dos subúrbios cariocas e frequentadores de bailes funk evidenciava como o preconceito poderia gerar a violência (Id. Bonde do mal. In: In: MAGGIE, Yvonne; REZENDE, Cláudia B. (org). Raça como retórica: a construção da diferença. Rio de Janeiro: Civilização Brasileira, 2001. p. 111-113).
} 
juventude no narcotráfico e a prática do surfe ferroviário no Rio de Janeiro a partir da ideia de risco. Segundo esta autora, "estes jovens, pobres em sua grande maioria, estariam mais submetidos aos riscos urbanos e, em especial, aos da violência. Por esse motivo, as condutas de risco poderiam se apresentar como forma de resposta ao próprio risco (...). Isto decorreria do fato de eles já terem uma familiaridade com ele". ${ }^{129}$

Apesar de a classe média alardear o nível insuportável de "violência urbana", que limita seu direito de ir e vir, o risco de andar pela cidade, de "dar um rolê", pode ser encarado como uma grande aventura prazerosa por membros de uma determinada subcultura. Vários membros de galeras funk declaram se sentir protegidos, em suas comunidades e bairros ou na companhia de seu grupo, de uma estrutura social excludente e dos perigos do espaço urbano.

Ao mesmo tempo, ainda que isso implique riscos à sua segurança, perambular pela cidade, a pé ou em transportes coletivos, sem destino certo, cantando e gritando expressões aparentemente incompreensíveis, se defrontar com "alemães" e transgredir fronteiras constituem "desafios" lúdicos que os fascinam. Esses territórios transitórios geralmente são construídos na ilusão libertadora da noite, longe do controle dos pais, patrões, professores, autoridades, etc. É quando as luzes da cidade se acendem que os jovens se sentem mais à vontade para tomá-la, pilhá-la, recriá-la e marcá-la. ${ }^{130}$

A grande fluidez na cidade, facilitada pelo desenvolvimento dos meios de transportes, acaba por determinar a impossibilidade de um efetivo controle social informal. ${ }^{131}$ Para muitos desses jovens, o envolvimento com grupos juvenis, que carregam a cultura e os valores próprios da idade, confere a possibilidade de uma libertação das pressões, exigências e tensões a que estão submetidos. A “subcultura da diversão" esbarra frequentemente em atos delinquenciais bastante sutis, mas muito barulhentos, que atribuem popularidade ao jovem dentro do grupo. ${ }^{132}$

Em seus deslocamentos pela cidade, as galeras parecem ora intimar os espectadores ao "rito do embate", das diferenças, ora convidá-los para uma espécie de festa dionisíaca

\footnotetext{
${ }^{129}$ Apud PEREIRA, Alexandre Barbosa, op. cit. p. 112-113. "O surfe-ferroviário é, talvez a prática que mais dramaticamente expressa o sentimento de exclusão social que perpassa esses grupamentos. Os surfistasferroviários parecem não se atribuir valor, nem demonstram ter perspectiva, pondo diariamente a vida em risco, mesmo tendo assistido tantas vezes um companheiro ser arrancado do teto do trem, por um cabo de sustentação da rede" (RIBEIRO, Manoel, op. cit. p. 291).

${ }^{130}$ HERSCHMANN, Micael, op. cit. p. 227 et seq.

${ }^{131}$ SHECAIRA, Sérgio Salomão. Importância e atualidade da Escola de Chicago. In: Discursos Sediciosos: crime, direito e sociedade, v. 9/10. Rio de Janeiro: Freitas Bastos, 2000. p. 156.

${ }^{132}$ Id. Criminologia. São Paulo: Editora Revista dos Tribunais, 2004. p. 257.
} 
que promove a suspensão temporária total ou parcial das diferenças - como no carnaval. A postura excludente parece partir muito mais da sociedade do que destes jovens. ${ }^{133}$ Nos shows de punk, a plateia interfere o tempo todo, o "público" é também “cena". Da mesma forma, para esses jovens, "a cidade se apresenta como espetáculo, como palco onde 'montam constantemente encenações"”.

Com o esgarçamento dos laços de intimidade na esfera da família e o abandono da crença na solidariedade de classe nos tempos modernos, as "fraternidades", gangues e galeras, baseadas na etnicidade e no local de moradia, inauguram um uso diferenciado, invertido do espaço urbano. Em vez de proteger-se por trás dos muros de casa, a ordem é exibir-se e movimentar-se no escuro, nos becos e até mesmo nos esgotos. A apropriação de espaços públicos centrais, como praças, parques e quadras esportivas, com o uso do terror e da violência, por sua vez, transfere, de certa forma, essas gangues "da obscuridade das favelas e do subúrbio para o espaço iluminado e ampliado da esfera pública, bem como para o 'centro` dos acontecimentos". Além disso, demonstra sua força em relação às demais gangues da área. ${ }^{134}$

A cidade é ocupada não apenas fisicamente. Nas letras dos funks verifica-se uma ocupação simbólica da cidade, na medida em que as comunidades dos MCs, muitas delas desconhecidas pelas camadas médias e altas da população, são cantadas e exaltadas. O desejo das galeras, expresso nas letras, é de ampliação das áreas de circulação e de reconhecimento de seus membros como legítimos moradores da cidade. ${ }^{135} \mathrm{Da}$ mesma forma, pichar é uma maneira de os jovens se apropriarem e invadirem simbolicamente as áreas nobres e centrais da cidade, deixarem sua marca, inscreverem o nome de seus bairros desconhecidos na cidade "ordenada", obterem visibilidade e fugirem da efemeridade, ainda que sob a forma da delinquência. ${ }^{136}$

\footnotetext{
${ }^{133}$ HERSCHMANN, Micael, op. cit. p. 236.

134 DIÓGENES, Glória. Rebeldia urbana: tramas de exclusão e violência juvenil. In: HERSCHMANN, Micael (Org). Abalando os anos 90: funk e hip-hop - globalização, violência e estilo cultural. Rio de Janeiro: Rocco, 1997. p. 118-120.

${ }^{135}$ Ibid. p. 122. A música é uma das mais evidentes formas de inscrição da "cidade dos excluídos" no imaginário coletivo urbano. As letras, especialmente no hip-hop, denunciam um cotidiano difícil, projetando a realidade da favela ou subúrbio dos MCs por toda cidade, e constroem uma nova cartografia urbana do Rio de Janeiro (HERSCHMANN, Micael, op. cit. p. 232-233).

136 HERSCHMANN, Micael, op. cit. p. 197, 231. Sua atitude pode ser interpretada como um não reconhecimento de si mesmos como "co-proprietários" daquele patrimônio (RIBEIRO, Manoel, op. cit. p. 290). Os trajetos e deslocamentos que os pichadores fazem pela cidade, contudo, são mais importantes para eles se apropriarem do espaço urbano do que o ato transgressivo de pichar (PEREIRA, Alexandre Barbosa, op. cit. p. 114). Shecaira narra o episódio dos paulistas que picharam a estátua do Cristo Redentor porque "queriam o estrelato" e "tiveram a maior emoção de suas vidas" (SHECAIRA, Sérgio Salomão. Criminologia. São Paulo: Editora Revista dos Tribunais, 2004. p. 261).
} 
Não se deve confundir, porém, a pichação com o grafite, expressão artístico-visual do movimento hip hop. O grafite surgiu espontaneamente no início dos anos 70 nas ruas dos guetos negros de Nova York. Inicialmente, num ato de transgressão e ousadia, os jovens pichavam os trens do metrô, com uma profusão de rabiscos indicando caligrafias de indivíduos ou gangues. Para se destacarem da poluição de rabiscos, as letras foram ficando cada vez mais largas e coloridas. Dos vagões, as disputas migraram para as paredes das ruas, chegando à elaboração de verdadeiros painéis coloridos que, atualmente ocupam grandes galerias de arte. ${ }^{137}$ Mesmo assim, ainda existe um preconceito recorrente em relação a essa manifestação artística e os rappers são constantemente acusados de incitar pichações nos principais centros urbanos. ${ }^{138}$

Uma das formas mais tradicionais de se ocupar a cidade é por meio dos "bondes". O termo possui diversos significados. Num deles, "bondes" designam comboios de traficantes, o que facilita a associação do funk com práticas criminosas, às vezes por vontade dos próprios MCs, conforme será analisado no capítulo 4. Mas os "bondes" também podem se referir a grupos de funk formados por alguns MCs e/ou dançarinos, a alianças entre galeras, a trenzinhos coreográficos que percorrem o baile funk, ao meio de transporte que leva a galera ao baile ou ao próprio deslocamento coletivo da galera pela cidade. "O bonde" é formado pela galera em algum lugar simbólico da comunidade, como a sede de um clube, e parte, por sua vez, para locais de lazer, como a praia, estádios de futebol, bailes funk e shoppings. ${ }^{139}$

Se há quem prefira ir à praia sozinho simplesmente por não gostar de confusão ou para não ser confundido com os baderneiros que formam o "bonde" e, consequentemente, ser alvo de galeras "alemãs" ou da polícia, muitos jovens se sentem protegidos e só acham divertido sair "de bonde". Por outro lado, muitos "bondes" gostam de ser vistos como ameaçadores, associados aos "bondes" de traficantes, tanto que se auto-denominam "bondes sinistros" ou "bondes do mal". O "bonde" faz sempre grande estardalhaço ao

\footnotetext{
${ }^{137}$ CARMO, Paulo Sérgio do, op. cit. p. 180.

${ }^{138} \mathrm{~A}$ confusão entre arte marginal, protesto político e vandalismo foi alçada à mídia de forma explosiva na ocasião da prisão de Caroline Pivetta da Mota, que pichou o "andar vazio" da Bienal de 2008. Convidada a participar oficialmente da Bienal de 2010, recusou o convite oficial, o que reforça o aspecto subcultural de seu comportamento. Para uma análise jurídica da distinção entre crime ambiental e grafite, cf. CYMROT, Danilo. Crimes contra o patrimônio arqueológico no ordenamento jurídico brasileiro. In: CARVALHO, Aline Vieira de; SOARES, Inês Virgínia Prado; FUNARI, Pedro Paulo A.; SILVA, Sérgio Francisco Serafim Monteiro da (Org.). Arqueologia, direito e democracia. Erechim: Habilis, 2009. p. 243-245.

${ }^{139}$ CUNHA, Olívia M. G. Bonde do mal. In: MAGGIE, Yvonne; REZENDE, Cláudia B. (org). Raça como retórica: a construção da diferença. Rio de Janeiro: Civilização Brasileira, 2001. p. 124; GUIMARÃES, Eloísa, op. cit. p. 152.
} 
passar, já que os jovens buscam ocupar a cidade ruidosamente, marcar presença, obter visibilidade e desafiar os perigos em que implicam as suas transgressões.

Ir de bonde às vezes pressupõe custos apenas burocráticos, como arrecadar dinheiro (eventualmente com os "contextos" da favela), fazer contato com equipes de som, providenciar ônibus, inscrever a galera em concursos, avisar os amigos e escolher os bailes. Outras vezes esse custo requer coragem e "disposição" para escolher a melhor linha de ônibus, impedir que o motorista pare em determinados pontos de território "alemão", "fechar o bonde" para a galera chegar mais rápido ao baile e "zoar muito". ${ }^{140} \mathrm{O}$ "bonde" acaba se envolvendo muitas vezes em arrastões, brigas, quebra-quebras e diversos atos de vandalismo.

Entretanto, o que pode parecer, para quem observa de fora, delinquência, violência e ameaça, é encarado por quem forma o "bonde" como brincadeira, "zoação". O verbo "zoar", a propósito, também possui múltiplos significados. Compreende desde ações como "beijar mulher na balada", falar besteira, rir e inventar passos diferentes, até fazer barulho no cinema com os amigos, fazer bagunça na escola, beber, usar drogas, brigar com os “alemães", passar embaixo da catraca para não pagar a passagem do ônibus ("viação calote"), gritar gritos de guerra, etc.

O que caracteriza a "zoação" é o fato de ser sempre uma atividade coletiva, na qual o estar junto é mais importante do que a atividade em si ou o local no qual ela é desempenhada ${ }^{141}$, o que é importante, tendo em vista que as opções de lazer dos jovens

\footnotetext{
${ }^{140}$ CUNHA, Olívia M. G. Conversando com Ice-T: violência e criminalização do funk. In: HERSCHMANN, Micael (Org.). Abalando os anos 90: funk e hip-hop - globalização, violência e estilo cultural. Rio de Janeiro: Rocco, 1997. p. 104-106.

141 "A gíria e os solecismos acabam funcionando como parte do sistema de segurança da quadrilha, dificultando o acesso e a compreensão de estranhos. 'Zoar` quer dizer 'aprontei muita confusão` ou também 'cheirei muito`. 'Resolver uma parada' tanto pode ser receber uma partida de droga ou um carregamento de armas como resolver um problema, cumprir um compromisso, executar um inimigo ou ir a um batizado. Como muitos desses vocábulos acabam indo para a Zona Sul junto com a cocaína, a renovação se faz necessária" (VENTURA, Zuenir, op. cit. p. 106). "O ato de 'zoar’, em sua apreensão semiológica, expressa a capacidade de fazer grande ruído, emitir som forte e confuso ou equivalente a zumbir, produzir ruído semelhante ao dos insetos (...) Além de acionar a dimensão numérica das aglomerações, o 'zoar` inscreve-se como condição essencialmente motora, de fricção tátil entre corpos em circulação, é gravitação de humores e intenções, é ocasião, contingência e segmentaridade. 'Zoar' é intervir no espaço, sempre inescapavelmente em grupo; não existe 'zoação` solitária, pois atravessa-se em conjunto os pontos da night, submetendo-os ao imperativo da sociabilidade. Na 'zoação', lugares cedem sua importância para o imperativo da regência grupal (...) É você 'estar solto`, 'perder a censura` (...) A dinâmica do 'zoar` também pode ser acompanhada em trânsito. Ou seja, é possível 'zoar` nos interstícios, nas zonas de passagem entre dois lugares, mais exatamente, no caminho (...) A 'curtição` sem objeto, verificada em sua absoluta gratuidade (...).É sempre a 'galera' que faz a 'ocasião', investe de interesse, graça e humor os lugares em si (...) Apesar desta constatação, alguns jovens destacam os cinemas e os shopping centers como pontos estratégicos para a 'zoação"” (ALMEIDA, Maria Isabel Mendes de; TRACY, Kátia Maria de Almeida. Noites nômades: espaço e subjetividade nas culturas jovens contemporâneas. Rio de Janeiro: Rocco, 2003. p. 125 et seq.). Inúmeras
} 
pobres é bastante limitada em virtude de seu baixo poder aquisitivo. Do ponto de vista sociológico, o lazer constitui-se em elemento de distinção e diferenciação. Os jovens de classe média e alta dispõem de espaços de interação tais como a própria casa, clubes, teatros, casas de shows, baladas, cinemas, restaurantes, shoppings, etc., e "demarcam seus espaços geográficos como patrimônio da classe média e dos turistas".

A maioria desses espaços é inacessível aos jovens pobres. Suas casas, por seu tamanho e condições, não são adequadas para as reuniões de amigos e nos shoppings geram suspeitas. Por isso, a não ser que passem seu tempo livre nas igrejas evangélicas, só dispõem como espaço de lazer dos terrenos baldios, bailes funk, parques públicos, ruas, praças, estações de metrô e praias, onde se expõem e, simultaneamente, tornam-se poderosos e vulneráveis a confrontos com galeras rivais ou policiais. ${ }^{142} \mathrm{O}$ surgimento da própria "cultura de rua", da dança break e do movimento hip hop como um todo, está relacionado a estas condicionantes de ordem sócio-econômicas.

Os membros de uma gangue somente se unem para circular pela noite, em busca de prazer, praticando pequenos delitos e atos de desordem, sem que haja um planejamento das atividades delituosas a serem praticadas em um futuro longínquo, com objetivo de obter vantagens específicas ou em um contexto de permanência. Parsons chama a atenção para uma subcultura de classe média hedonista e irresponsável, que advém das tensões naturais existentes entre adultos e adolescentes. ${ }^{143}$ Nesse sentido, teve grande repercussão o assassinato do índio pataxó Galdino. Quatro jovens de classe média-alta, que pretendiam apenas divertir-se na noite de Brasília, "procuravam algo pra fazer", "um lugar para ir". Ao encontrar Galdino dormindo na rua, resolveram fazer "uma brincadeira", "zoar", imitar uma "pegadinha" da televisão e atearam fogo em seu cobertor. ${ }^{144}$

\footnotetext{
são as referências a diversões que surgem do "nada", do acaso, do próprio tédio (Ibid. p. 130). Uma bola de futebol de madrugada, o espaço de um hortomercado, e a falta do que fazer é condição suficiente para a instalação da "zoação" entre a "galera" (Ibid. p. 135).

142 ARCE, José Manuel Valenzuela, op. cit. p. 100-101; CARMO, Paulo Sérgio do, op. cit. p. 218; MINAYO, Maria Cecília de Souza et alii, op. cit. p. 51-52, 56, 62.

${ }^{143}$ Apud SHECAIRA, Sérgio Salomão. Criminologia. São Paulo: Revista dos Tribunais, 2004. p. $253-255$.

${ }^{144}$ Ibid. p. 264-265.
} 


\subsection{A contextualização histórico-política do arrastão e a criação de pânicos morais pela mídia}

Apenas entre os dias 30 de setembro e 18 de outubro de 1992, houve a autorização para o processo de impeachment do presidente Fernando Collor, o massacre do Carandiru e o arrastão do Arpoador. ${ }^{145}$ Segundo a cronologia Brasil do Almanaque Abril de 1993, além de outubro de 1992 ter sido o mês da comemoração da queda do presidente Collor, foi o mês da abertura da CPI que investigou as denúncias da privatização da VASP, revelando atos irregulares do ex-governador de São Paulo, Orestes Quércia. Foi ainda o mês em que o Procurador Geral da República, Aristides Junqueira, publicou um parecer inocentando o ex-ministro da Saúde do governo Collor, Alceni Guerra, do escândalo das bicicletas. Em relação à economia, no dia 22 de outubro a Acesita foi vendida em leilão para a Previ e um consórcio de bancos 29,5\% acima do preço mínimo, sem descontar as moedas podres. Esses dados apontam para alguns fatos que foram ofuscados pelo excesso de desdobramentos do arrastão.

Kleber Mendonça observa que a hiperdimensão do arrastão pela mídia permite que se encontre uma causa para muitos dos problemas brasileiros, como a imagem comprometida do país no exterior, a crise no turismo, no mercado imobiliário e na economia. O jornal inverte a sequência, como se não fosse a crise econômica a geradora da insegurança permanente e das dificuldades no setor turístico. Num país grande como o Brasil, o turismo interno também seria uma fonte de renda, caso o brasileiro não sofresse os efeitos da crise econômica. A queda no turismo, por sua vez, já vinha ocorrendo há muito tempo. Quanto à desvalorização dos imóveis, não se faz uma associação entre a cotação imobiliária em dólar e a desvalorização diária da moeda brasileira.

A inserção do tema "arrastão" na seção "Brasil" e "Política e Economia" dos jornais fez com que o evento arrastão fosse apontado como o retrato do Brasil naqueles dias e associou o país à decadência. A ode às praias dos anos 70 pode ser lida como uma exaltação do milagre econômico da época da ditadura, a uma Cidade Maravilhosa em que os conflitos sociais eram abafados e em que as praias ainda "eram nossas". Quando relaciona o arrastão como causa de problemas brasileiros, o jornal faz opções por temas que ganham destaque muito maior do que se fossem veiculados isoladamente. Por outro

${ }^{145}$ YÚDICE, George, op. cit. p. 29 et seq. 
lado, a opção editorial silencia a presença da crise política, econômica e social na origem destes mesmos problemas. ${ }^{146}$

É importante destacar que o arrastão do Arpoador ocorreu às vésperas do segundo turno das eleições municipais do Rio de Janeiro. A candidata negra e favelada Benedita da Silva, do PT, tinha chances reais de vencer o candidato César Maia, o que fez com que muitos enxergassem intenções eleitorais no hiperdimensionamento do arrastão pela mídia, além do objetivo de enfraquecer politicamente o então governador Leonel Brizola. ${ }^{147}$ Brizola, estranhando o posicionamento estratégico de câmeras da TV Globo no momento do suposto arrastão, criticava o racismo e preconceito que permeava o debate e propunha como solução de ordem prática a criação de piscinas olímpicas nos CIEPs para o lazer da "população carente".

Benedita da Silva defendia o direito de ir e vir de todos os moradores da cidade, em especial dos moradores das periferias e favelas. Já César Maia defendia a manutenção da ordem, anteviu a necessidade de convocação das Forças Armadas para tal e popularizou, durante a campanha eleitoral, o conceito de "cidade dual", que, segundo ele, estava dividida entre a ordem e a desordem, sendo que esta era moradora exclusiva do lado pobre, representado pela candidata Benedita da Silva. ${ }^{148}$

Este quadro em que o funk alcançou "notoriedade" marcou, portanto, também um momento de polarização de propostas de políticas públicas para o país, motivado, por um lado, pelo crescimento dos segmentos marginalizados e a comoção social promovida por chacinas como a do Carandiru, Candelária e Vigário Geral, e, por outro lado, pela presença desafiadora dos narcotraficantes nos "bolsões de miséria", os crimes cada vez mais

\footnotetext{
${ }^{146}$ MENDONÇA, Kleber, op. cit. p. 277 et seq; VENTURA, Zuenir, op. cit. p. 97. Nesse sentido, cabe mencionar que, para os criminólogos críticos, o cárcere cumpre uma função diversiva na medida em que joga o foco nos crimes praticados pelas camadas baixas da população, geralmente patrimoniais, e tira a atenção do público dos crimes praticados pelas camadas altas, que geralmente são mais prejudiciais e atingem bens difusos, como o meio ambiente, o sistema econômico e financeiro, as relações de trabalho e de consumo (SHECAIRA, Sérgio Salomão. Criminologia. São Paulo: Editora Revista dos Tribunais, 2004. p. 355-356).

${ }_{147}$ VIANNA, Hermano, op. cit. p. 180-181; CARMO, Paulo Sérgio do, op. cit. p. 168; MENDONÇA, Kleber, op. cit. p. 277 et seq.; BATISTA, Vera Malaguti. O medo na cidade do Rio de Janeiro: dois tempos de uma história. Rio de Janeiro: Revan, 2003. p.19-20.

${ }^{148}$ CUNHA, Olívia M. G. Bonde do mal. In: MAGGIE, Yvonne; REZENDE, Cláudia B. (org). Raça como retórica: a construção da diferença. Rio de Janeiro: Civilização Brasileira, 2001. pp. 98-99; VENTURA, Zuenir, op. cit. p. 90. Vera Malaguti Batista critica, da mesma forma, o conceito de "cidade partida", que refletiria a "nostalgia conservadora" de Zuenir Ventura (BATISTA, Vera Malaguti. O medo na cidade do Rio de Janeiro: dois tempos de uma história. Rio de Janeiro: Revan, 2003. p. 111). Para José Manuel Valenzuela Arce, "o eixo enviesado que guiou o olhar entre o asfalto e a favela foi a violência urbana, uma violência que se apresenta com origem definida nas favelas, nos morros onde habitam os pobres, nas ruas contaminadas e ameaçadas por sua presença, onde estes assaltam, realizam comércio informal ou dormem nas cornijas dos edifícios, obstinados a demonstrar a incapacidade teórica daqueles que realizam construções binárias entre os espaços públicos e os privados" (ARCE, José Manuel Valenzuela, op. cit. p. 95).
} 
espetaculares exibidos pela mídia e a crescente sensação de insegurança nas grandes cidades.

Duas correntes têm se destacado na grande imprensa. A primeira, representada pelas ONGs e pelas Comissões de Direitos Humanos, defende que o caminho para se resolver a criminalidade passa pela resolução das chamadas "injustiças sociais". A segunda corrente, representada por parte do empresariado e pelos setores mais conservadores da sociedade, considera os atuais órgãos de segurança pública e da Justiça incapazes de resolver os graves "problemas sociais" e, por isso, clamam por medidas de "impacto" que visem a aumentar o contingente policial, com a colaboração do Exército, reaparelhar estas instituições, etc. ${ }^{149}$

\subsection{O lado producente da violência}

Durkheim afirma que o crime não é um fato necessariamente nocivo, na medida em que pode ser um elemento desencadeador de mudanças sociais e essencial ao fortalecimento da consciência coletiva, os valores que presidem à ordem social. ${ }^{150}$ Fugindo de uma óptica criminalizante reducionista, Herschmann defende que a violência não é um resquício de um "barbarismo maldito", mas um importante recurso que garante a perpetuação e a renovação social, presente em qualquer coletividade. Ela possui um papel constitutivo e não apenas destrutivo, constituindo uma linguagem que expressa a heterogeneidade social e os conflitos que podem emergir na forma de manifestações culturais. Os jovens que participaram dos arrastões só ganharam espaço na mídia e, posteriormente, junto ao Estado na medida em que se tornaram uma possível "ameaça à ordem”. No entanto, tornar-se uma ameaça não faz parte de uma estratégia das lideranças do mundo funk carioca. Estes tipos de protesto possuem quase sempre uma conotação catártica. $^{151}$

De certa forma, esta demanda por visibilidade foi atendida, pois o mesmo evento que desencadeou uma política de repressão, estigmatização e criminalização da juventude pobre e negra das favelas, glamorizou o funk, inseriu-o também nas páginas culturais dos jornais, expandiu seu mercado para as classes médias e altas, colocou o tema do espaço do

\footnotetext{
${ }^{149}$ HERSCHMANN, Micael, op. cit. p. 99.

${ }^{150}$ Apud SHECAIRA, Sérgio Salomão. Criminologia. São Paulo: Editora Revista dos Tribunais, 2004. p. 220; DURKHEIM, Émile. Da divisão do trabalho social. São Paulo: Martins Fontes, 1995. p. 39 et seq.

${ }^{151}$ HERSCHMANN, Micael, op. cit. p. 42 et seq.
} 
jovem e do pobre na sociedade em pauta e deu origem a uma série de seminários e eventos acadêmicos para pensar políticas públicas não repressivas, sendo que algumas acabaram colocadas em prática, como o Projeto Rio Funk, do Centro Brasileiro para Infância e Adolescência.

O Projeto Rio Funk, de 1993, gerenciado pela Secretaria Municipal de Desenvolvimento Social, ofereceu a jovens de 12 comunidades carentes oficinas e cursos, inclusive de DJ, como forma de valorizar a cultura funkeira e aproximá-los do Estado. ${ }^{152}$ Foram oferecidos bailes grátis, dando alternativa para quem não queria ou podia participar dos confrontos nos grandes bailes de clube. Além dessas iniciativas, foi trabalhado um processo de pacificação entre as galeras de Vigário Geral e Parada de Lucas, que compreendeu a realização de um "baile da paz" na fronteira entre Vigário e Parada, com a presença de astros do funk; um vídeo de educação sexual dirigido à juventude de periferias, com linguagem funk e artistas de Vigário Geral; um vídeo de Bezerra da Silva, o Grupo O Rappa e a galera de Parada de Lucas, cantando as artimanhas dos candidatos que aparecem na favela em época de eleição; competições esportivas e eventos culturais conjuntos. $^{153}$

${ }^{152}$ HERSCHMANN, Micael, op. cit. p. 112, 116-117, 223, 228-229, 248. O discurso nem sempre traduz-se num projeto ideológico claro de quem o produz. O discurso que demoniza o funk e o hip-hop é o mesmo que assenta as bases para a sua glamorização. A mídia, a sociedade, os políticos e os jovens não são homogêneos. A mesma mídia que demoniza é aquela que também abre espaços nos jornais e programas de televisão (Ibid. p. 87-89). Cf. também CUNHA, Olívia M. G. Conversando com Ice-T: violência e criminalização do funk. In: HERSCHMANN, Micael (Org.). Abalando os anos 90: funk e hip-hop - globalização, violência e estilo cultural. Rio de Janeiro: Rocco, 1997. p. 92; ESSINGER, Silvio, op. cit. p. 130. O artista plástico Artur Omar visualizava que, ao desfazer-se das marcas da violência, o arrastão poderia transformar-se num ato performático e artístico. O debate sobre a violência do arrastão foi sucedido pela descoberta da dimensão cultural do funk e pela percepção de que "não são os jovens 'suburbanos' a causa do incômodo, mas a ausência de ordem e disciplina no uso dos bens públicos. Não é a música que escutam que ensurdece, mas os códigos a ela relacionados, que contêm termos e insinuam práticas ligadas à guerra do tráfico e à criminalidade" (CUNHA, Olívia M. G. Bonde do mal. In: MAGGIE, Yvonne; REZENDE, Cláudia B. (org). Raça como retórica: a construção da diferença. Rio de Janeiro: Civilização Brasileira, 2001. p. 100).

${ }^{153}$ RIBEIRO, Manoel, op. cit. p. 289; VENTURA, Zuenir, op. cit. p. 158 et seq. Jovens que queriam ser MCs, DJs e dançarinos haviam parado de frequentar bailes de briga logo após os "arrastões" (CECCHETTO, Fátima, op. cit. p. 115-116). Deve-se, porém, ter cuidado para não idealizar o trabalho de ONGs e a boa vontade com que a mídia trata projetos que buscam "resgatar" a juventude através da música. Conforme nos lembra Sylvia Moretzsohn, "são fartos os exemplos de cobertura que enfocam os pobres como perigosos. Por isso, vale a pena enfatizar o lado do 'olhar benevolente', mesmo porque ele costuma ser louvado como contribuição positiva (ou 'pró-ativa', no jargão da moda): ali estão pobres honestos, ordeiros e trabalhadores, empenhados em melhorar de vida pelo próprio esforço, ainda que seus horizontes sejam sempre limitados às ocupações subalternas que lhes foram historicamente reservadas, fora das quais só há salvação no talento para a música ou o esporte; então aparecem em ensaios de teatro, dança, capoeira, futebol, rodas de chorinho e samba, ou em oficinas para trabalhos manuais variados, às vezes valorizados pelo que podem proporcionar de 'criatividade'- e vemos gente sorridente usando sucata para fazer artesanato ou confeccionar instrumentos musicais para projetos que ‘afastam o jovem do tráfico` (...) O olhar benevolente é ajustado ao enfoque e aos limites de ação do voluntário bem intencionado. Se a iniciativa não dá certo, a culpa é de quem não soube aproveitar a oportunidade, e o benfeitor pode serenamente lavar as mãos" (MORETZSOHN, Sylvia. O caso 
Realmente, não se pode fazer o combate à criminalidade subcultural com a tradicional repressão, mas com um processo de cooptação dos grupos, inserindo-os no mercado de trabalho e oferecendo-lhes o acesso à sociedade produtiva. Na gestão da exprefeita de São Paulo Luiza Erundina, por exemplo, houve a "concessão" de alguns muros da cidade, em locais de grande visibilidade, onde os jovens podiam livremente grafitar. A ex-prefeita Marta Suplicy, por sua vez, incentivou os grupos de periferia de hip hop, antes associado estereotipicamente à marginalidade. ${ }^{154}$

A Escola de Chicago já previa que instituições locais, igrejas, escolas e associações de bairro deviam se envolver em programas preventivos que combatessem a desorganização social e reconstruíssem o controle social informal, intensificando atividades recreativas para preencher o tempo livre dos jovens e concebendo uma nova divisão territorial para conscientizar a comunidade de que áreas comuns, como praias e metrôs, são áreas pertencentes à comunidade e, portanto, dignas de proteção por todos. ${ }^{155}$

Em dezembro de 1992, foi realizado o seminário "Barrados no Baile: entre o funk e o preconceito", promovido pela Fundação Carlos Chagas Filho de Amparo à Pesquisa do Estado do Rio de Janeiro (FAPERJ). Na abertura, o então secretário de Justiça e de Polícia Civil Nilo Batista defendeu o funk: "é mais fácil ter medo de um garoto de 16 anos do que do sistema. Jogamos sobre pobres e destituídos os nossos medos. Os funkeiros pagam uma taxa de toda a violência urbana”. Rômulo Costa, dono da Furacão 2000, pediu permissão para realizar seus bailes nos CIEPs.

O prefeito César Maia, aparentemente convencido de que o funk era o único movimento jovem sistemático e permanente do Brasil, prometeu ceder espaços da Prefeitura, como a Praça da Apoteose, para os bailes. Declarou que o funk era "um movimento cultural reconhecido pela Prefeitura", disse querer "levar as galeras, com o seu balé aprimorado, para as portas de hotéis" e até criar um Dia do Funk e um "vale-lazer",

Tim Lopes: o mito da "mídia cidadã". In: Discursos Sediciosos: crime, direito e sociedade, vol. 12. Rio de Janeiro: Editora Revan, 2002. p. 299-300).

${ }^{154}$ SHECAIRA, Sérgio Salomão. Criminologia. São Pauilo: Editora Revista dos Tribunais, 2004. p. 268-269. Tendo-se comprovado que os autores dos grafites pichavam os vagões do metrô de Nova York para se recriar depois com sua obra, vendo-os circular pela cidade, uma equipe de criminólogos sugeriu adotar duas medidas concretas que se mostraram altamente eficazes: a limpeza imediata dos vagões antes que estes iniciassem seu percurso diário e o emprego de materiais especiais recobrindo as paredes dos vagões para o efeito de impossibilitar que a pichação se impregnasse aos mesmos (GOMES, Luiz Flávio; GARCÍA-PABLOS DE MOLINA, Antonio. Criminologia. 7. ed. São Paulo: RT, 2000. p. 358).

${ }^{155}$ SHECAIRA, Sérgio Salomão. Importância e atualidade da Escola de Chicago. In: Discursos Sediciosos: crime, direito e sociedade, v. 9/10. Rio de Janeiro: Freitas Bastos, 2000. p. 161-162; RIBEIRO, Manoel, op. cit. p. 292. Na década de 70, Messiê Lima já dizia que os bailes black deviam ser estimulados pelo governo, porque sem eles, "haveria um aumento grande nos assaltos nos finais de semana, o pessoal sem ter o que fazer, sem ter como se divertir" (ESSINGER, Silvio, op. cit. p. 32). 
que traria a passagem de ônibus embutida no preço dos ingressos para os bailes. Para ele, a política de diversificar os locais para realização dos bailes era a melhor opção para se acabar com a violência das galeras. $\mathrm{O}$ funk foi encarado naquele momento como um fato consumado, muito difícil de sufocar, e o que se deveria fazer era dar condições para que ele se desenvolvesse da forma mais ordeira possível. ${ }^{156}$

\footnotetext{
${ }^{156}$ ESSINGER, Silvio, op. cit. p. 126-128. Um ano após o "I Seminário sobre Violência-a Questão Funk", foi realizado o workshop "Galeras: uma manifestação cultural? Uma ameaça? Um problema da cidade?" no Fórum de Ciência e Cultura da Universidade Federal do Rio de Janeiro. O então prefeito César Maia abriu os trabalhos revelando que o funk era "o mais importante movimento jovem do Brasil". Quase todos os participantes tentavam encontrar soluções para a questão da violência, bem como para o excessivo barulho dos bailes, que não deixava os moradores vizinhos dormirem. Propuseram-se medidas como policiamento na entrada e saída dos salões, melhores condições de transporte, mais espaços para a realização de bailes, isolamento dos baderneiros pelos líderes de galeras e organizadores dos bailes, distribuição de carteiras entre os funkeiros e gincanas de galeras que contemplassem mais o desempenho artístico do que os feitos viris. Maria Teresa Monteiro defendia que a integração dos funkeiros era necessária para evitar a luta de classes, arrastões sistemáticos e até a entrada do Exército em cena (VENTURA, Zuenir, op. cit. p. 151 et seq.). Cf. também RIBEIRO, Manoel, op. cit. p. 289.
} 


\section{O BAILE DE CORREDOR}

\subsection{As características principais do baile de corredor}

Os bailes funk, em meados da década de 90, podiam ser divididos em três categorias: o baile normal, o baile de corredor ou de embate e o baile de comunidade, o qual será estudado no capítulo seguinte. Bailes de comunidade são em geral gratuitos, realizados em quadras, clubes e terrenos dentro das favelas ou bairros populares. Conforme visto no capítulo anterior, nesses bailes as brigas não são admitidas pelos traficantes. ${ }^{157}$ Já os bailes normais e os de corredor são pagos e ocorrem em clubes, escolas de samba e CIPES do subúrbio do Rio de Janeiro e Baixada Fluminense. Contam geralmente com instalações precárias e área física incompatível com o número de frequentadores. A diferença entre o baile normal e o baile de corredor está no tempo e no espaço destinados ao confronto entre as galeras. Na maioria dos bailes normais, as brigas são vetadas. Há outras atrações, como sessões de músicas lentas, românticas e eróticas, shows de MCs e gincanas.

Na minoria dos bailes normais em que a briga é permitida, o tempo dela é limitado severamente pelos organizadores. Durante o evento, os seguranças reprimem qualquer esboço de briga, mas, quando o baile chega ao final, se afastam e ocorre o que se convencionou chamar de "quinze minutos de alegria", momento em que temporariamente o baile fica dividido em dois territórios e as galeras se enfrentam em um "corredor".

Já nos bailes de corredor, que são minoritários e sofreram a influência dos "quinze minutos de alegria”, a briga é a tônica da festa e é organizada pelas equipes de som e DJs. O espaço do baile é dividido em dois territórios, lado A e lado B, para que as galeras se confrontem abertamente. O corredor forma uma linha imaginária que separa amigos e inimigos e onde ficam seguranças que controlam a excitação excessiva. Ao contrário do baile comum, em que as galeras rivais convivem nos mesmos espaços, no baile de corredor nenhum membro dos territórios A e B se atreve a cruzar a fronteira marcada pelo corredor. Para evitar que isso aconteça, existem bares e banheiros localizados em ambos os lados. ${ }^{158}$

\footnotetext{
${ }^{157}$ CUNHA, Olívia M. G. Bonde do mal. In: MAGGIE, Yvonne; REZENDE, Cláudia B. (org). Raça como retórica: a construção da diferença. Rio de Janeiro: Civilização Brasileira, 2001. p. 147-148.

${ }^{158}$ HERSCHMANN, Micael. O funk e o hip hop invadem a cena. Rio de Janeiro: Editora UFRJ, 2000. p. 173-174; CECCHETTO, Fátima. "As galeras funk cariocas: entre o lúdico e o violento". In: VIANNA, Hermano (Org.). Galeras cariocas: territórios de conflitos e encontros culturais. Rio de Janeiro: Editora da
} 
Os bailes de corredor são, em sua grande maioria, realizados em territórios "neutros", onde as galeras representam seus territórios de origem. O conflito, desta forma, é de domínio territorial e de afirmação geopolítica. Quanto mais distantes do seu território de origem, mais esses jovens se sentem frágeis e, por mais paradoxal que possa parecer, mais engajados em lutar por um lugar, pelo reconhecimento. ${ }^{159}$

De acordo com depoimentos de seus membros, algumas galeras vão aos bailes apenas para brigar, armadas de paus, correntes, pedras. Impedidas de levá-los para dentro dos clubes pelos seguranças, que fazem revistas rigorosas na entrada, esses instrumentos permanecem escondidos fora e são recuperados na saída, quando os conflitos se radicalizam. ${ }^{160}$ Muitas vezes, os embates regulados dos salões ficam fora de controle na saída dos bailes e as galeras, ainda eufóricas, dão continuidade às brigas com ainda mais violência: invadem edifícios, fazem barulho, promovem quebra-quebras e outros distúrbios nas ruas das proximidades. Por essa razão, os moradores das vizinhanças enxergam os bailes como sinônimo de confusão, violência, "reunião de desocupados", e tentam encontrar uma forma de acabar com eles.

Os ônibus para transportar os jovens já são poucos e, com medo de depredações e confusões, os motoristas, conhecendo o horário do final dos principais bailes, mudam suas rotas ou se recusam a parar nos pontos onde a multidão que sai das festas se aglomera. Os frequentadores do baile têm que esperar horas para voltar de ônibus para casa, mas geralmente moram perto do local da festa e voltam andando em bandos para suas ruas. ${ }^{161}$ Pensando no risco do encontro de galeras rivais na saída dos bailes, vários clubes organizam o transporte para as galeras de diversas localidades. Os líderes de galera coordenam a evacuação do baile e sabem que qualquer briga naquele momento pode significar a perda do direito ao ônibus que os organizadores dos grandes bailes colocam à disposição. ${ }^{162}$

UFRJ, 1997. p. 99-100; DAYRELL, Juarez. A música entra em cena: o rap e o funk na socialização da juventude. Belo Horizonte: Editora UFMG, 2005. p. 128; ARCE, José Manuel Valenzuela. Vida de barro duro: cultura popular juvenil e grafite. Rio de Janeiro: Editora UFRJ, 1999. p. 106-107; VENTURA, Zuenir. Cidade partida. São Paulo: Companhia das Letras, 1994. p. 121. O relato etnográfico de um baile comum em Belo Horizonte pode ser encontrado em DAYRELL, Juarez, op. cit. p. 137 et seq.

${ }^{159}$ HERSCHMANN, Micael, op. cit. p. 160-161.

${ }^{160}$ GUIMARÃES, Eloísa. Escola, Galeras e Narcotráfico. Rio de Janeiro: Editora da UFRJ, 2003. p. 185.

${ }^{161}$ RIBEIRO, Manoel. "Funk'n Rio: vilão ou big business?" In: Revista do Patrimônio Histórico e Artístico Nacional, n. 24. Ministério da Cultura, IPHAN, 1996. p. 288.

${ }^{162}$ HERSCHMANN, Micael, op. cit. p. 142. Cf. um relato etnográfico do baile de corredor em Ibid. p. 134 et seq. Cf. o relato de Dudu Nobre dos problemas enfrentados pelas galeras nas saídas dos bailes em ESSINGER, Silvio. Batidão: uma história do funk. Rio de Janeiro: Record, 2005. p. 115-117. 
Se as brigas não são resolvidas no baile ou em suas imediações, por causa da atuação dos seguranças ou da fuga dos grupos que se encontram em desvantagem, numérica ou instrumental, elas se transferem para outros espaços, como as escolas. As brigas são um importante instrumento na constituição das galeras e na preservação de sua existência. ${ }^{163}$ Elas podem surgir em contextos diversos, ocorrendo sempre que duas ou mais delas se encontram, mas a situação mais propícia à sua eclosão parece ser a dos bailes, pela possibilidade de reunião de grupos diferentes, quando qualquer ação ou, às vezes, a simples presença dos grupos inimigos pode desencadear o conflito. ${ }^{164}$ A esse respeito, destaca-se a seguinte jurisprudência, do Tribunal de Justiça do Rio de Janeiro:

0019477-49.1996.8.19.0000 (1996.059.00999) - HABEAS CORPUS DES. ALBANO MATTOS CORREA - Julgamento: 12/11/1996 - PRIMEIRA CÂMARA CRIMINAL

"Considerando que o crime imputado aos dois primeiros acusados foi incluído no rol dos denominados crimes hediondos; considerando a repercussão e o clamor público provocado pelo evento criminoso, tendo o mesmo dado continuidade a outros crimes da mesma natureza e circunstâncias, pelas chamadas 'galeras' de baile funk, deixo de conceder liberdade aos dois primeiros acusados, como forma de garantir a ordem social e final julgamento, possibilitando eventual aplicação da norma penal" (...) "2-Trata-se de crime praticado dentro de um clube, em plena pista de dança, durante um baile funk que ali se realizava. Este foi mais um dos crimes ocorridos na região decorrentes de divergências entre as chamadas galeras". A leitura atenta dos autos não traz à mente nenhum argumento favorável à soltura do Paciente.

0012390-81.1992.8.19.0000 (1992.059.00885) - HABEAS CORPUS DES. PAULO GOMES DA SILVA FILHO - Julgamento: 01/12/1992 PRIMEIRA CÂMARA CRIMINAL

O Dr. Juiz de Direito não deixou de atender ao requisito da fundamentação, pois afirmou, no despacho impugnado, que os autos encerram informes ensejadores da imposição da custódia, necessária, "principalmente para garantia da ordem pública, vez que o acusado em liberdade pode vir novamente a maculá-la, como bem ressaltou o doutor Promotor de Justiça em sua promoção de fls. 43”. E em tal pronunciamento o representante do Ministério Público salientou que se cuida de acontecimento relacionado com disputa entre "gangs". É de ver-se, portanto, que a essência da denegação do benefício reclamado, que não se pode ter como direito absoluto do réu, está na possibilidade de reeditar-se a prática ilícita, e isso o magistrado deixou bastante claro, servindo a invocação final do parecer do órgão acusador como simples respaldo para a assertiva, pelo fato de estarem envolvidos no fato jovens integrantes de grupos adversários, frequentadores dos chamados "bailes funks", como advertem as informações. E são notórias e frequentes as badernas para as quais descambam tais reuniões, propícias a excessos.

${ }^{163}$ GUIMARÃES, Eloísa, op. cit. p. 185.

${ }^{164}$ Ibid, p. 109; CECCHETTO, Fátima, op. cit. p. 98-99. 
0031275-31.2001.8.19.0000 (2001.050.02678) - APELAÇÃO

DES. MANOEL ALBERTO - Julgamento: 09/10/2001 - QUINTA CÂMARA CRIMINAL

Justifica-se a pequena exacerbação da pena-base quando o apelante ostenta antecedentes, afinal concretizada no mínimo legal pelo reconhecimento das atenuantes da menoridade relativa e da confissão espontânea. Substituição da pena privativa de liberdade. Defender-se de integrantes de galera rival de bailes funk, justificativa apresentada pelo apelante para andar armado, recomenda a imposição de sursis, e não a substituição da pena privativa de liberdade por restritiva de direito. Recurso a que se nega provimento.

\subsection{O papel das equipes de som: ascensão e decadência do baile de corredor}

Apesar do discurso oficial de que eram contra as brigas, as equipes de som foram acusadas de estimular a violência no baile e lucrar com isso. A rivalidade entre as equipes favorecia a troca de acusações e dificultava a reação à criminalização do funk. ${ }^{165}$ Clésio Braga defende o irmão Zezinho, dono da equipe ZZ Discos, do estigma de ter inventado o baile de corredor. Segundo Braga, a violência foi aumentando gradativamente no funk e chegou uma hora em que ela virou uma coisa normal, passou a fazer parte do baile. Como não houve repressão nenhuma, os produtores organizaram a briga e chegou um ponto em que ninguém podia tirar aquilo. Para piorar, na Baixada Fluminense, onde ocorriam os bailes da ZZ, a "situação financeira era um pouco mais baixa e o pessoal brigava mais". ${ }^{166}$

Já Verônica Costa, ex-esposa de Rômulo Costa, dono da equipe Furacão 2000, afirma que, cansada de ver seus bailes vazios por causa da concorrência de Zezinho, ela começou a promover também bailes de brigas, só que com regras. Se um dançarino "sequestrasse" o outro, pegasse de um lado do corredor para o outro, ficaria um mês sem entrar no baile, o pior castigo. Verônica admite que considerava aquela "brincadeira" violenta, mas que tinha que permitir que as galeras brigassem para tirá-las da ZZ Discos,

\footnotetext{
${ }^{165}$ Em agosto de 1996, Rômulo Costa, da Furacão 2000, visitou a Assembleia Legislativa do Rio de Janeiro para denunciar a "pancadaria" no funk e declarou que iria pedir à Secretaria de Segurança Pública uma vigilância maior nos bailes do rival José Cláudio Braga, o Zezinho, da ZZ Disco (ESSINGER, Silvio, op. cit. p. 184; HERSCHMANN, Micael, op. cit. p. 251-252). Zezinho, por sua vez, acusava Rômulo de filmar cenas de violência em seus próprios bailes e apresentá-las à polícia como tendo sido feitas nos bailes da ZZ (ESSINGER, Silvio, op. cit. p. 188-189). Uma investigação do Ministério Público resultou na instauração de uma CPI na Assembleia do Rio de Janeiro, em setembro de 1998, que culminou nas prisões de Zezinho, por causa da apreensão de "fitas que mostravam menores tirando a roupa em troca de dinheiro, além de muitas brigas" e de Rômulo Costa, sob a acusação de apologia do crime, corrupção de menores e falsidade ideológica. Foram interditados os principais bailes de corredor do Rio durante os primeiros meses de 1999 (MEDEIROS, Janaína. Funk carioca: crime ou cultura? O som dá medo. E prazer. São Paulo: Editora Terceiro Nome, 2006. p. 67).

${ }^{166}$ ESSINGER, Silvio, op. cit. p. 193.
} 
tanto que conseguiu trazê-las para os bailes de corredor da Furacão, "com um monte de regras".

Em reuniões quase diárias com as galeras em suas comunidades, algumas delas perigosas, a Mãe Loura do Funk, como é conhecida, usava sua autoridade junto aos seus "filhos" para dar conselhos, lições de moral e garantir que não houvesse conflitos mais sérios no final de semana. Ameaçava, por exemplo, impedir a entrada no baile de quem depredasse o ônibus no caminho e não disponibilizar mais este transporte para as galeras. Em 1998, contando com popularidade maior, graças aos programas da Furacão 2000 na Rádio Imprensa FM e na TV CNT, e aproveitando a onda de sucesso das coreografias de axé, Verônica Costa resolveu aos poucos minar o clima de briga, promovendo bailes de coreografia.

No começo, $10 \%$ do baile eram destinados a músicas para dançar e $90 \%$ para o corredor. As meninas dançavam de maneira bastante sensual e começaram a chamar mais a atenção dos meninos. $\mathrm{O}$ tempo destinado à dança foi aumentado gradativamente até que aos poucos o baile todo começou a dançar, inclusive os meninos, que abandonaram o interesse pela briga. Verônica pegava o microfone e se dirigia aos brigões, dizendo que, suados, fedidos e desarrumados daquele jeito, não conseguiriam "arrumar nenhuma gatinha" nem ser um grande cantor. Finalmente, brigar nos bailes passou a ser sinônimo de "pagar mico", os MCs voltaram e os bailes de corredor se dissolveram. ${ }^{167}$

O funk pornográfico, que já existia, tornou-se hegemônico justamente após o declínio do "funk bandido" e do baile de corredor, motivado também pela intervenção da mídia e pela repressão das autoridades. A "disposição" passa a ser para a conquista das mulheres, não mais para a destruição entre homens. Os homens abandonam a dança da

167 MEDEIROS, Janaína, op. cit. p. 62 et seq. Em 1994, Rômulo Costa, então presidente da Liga Independente das Equipes de Som, propôs que se criasse uma carteira de funkeiro. Cada equipe cuidaria de confeccionar a sua e o frequentador que não estivesse registrado ficaria impedido de ir aos bailes. Quem fosse pego brigando, seria suspenso por seis meses e os reincidentes teriam seu registro cassado (ESSINGER, Silvio, op. cit. p. 130). Em relação à violência das torcidas organizadas de futebol, Murad defende, da mesma forma, a articulação de medidas de caráter reeducativo, preventivo e corretivo, de forma sistemática e permanente e não episódica, como resposta aos reclamos da mídia. Entre essas medidas, destacam-se as campanhas de pacificação, envolvendo os chefes de torcidas e os principais jogadores de cada equipe; palestras e debates com torcedores; reuniões periódicas das polícias civil e militar com as torcidas; delegacia móvel nos grandes estádios; proibição da venda de bebida alcoólica dentro dos estádios e nos arredores; revista rigorosa e permanente em torcedores e torcedoras; melhoria do sistema de transporte coletivo, principalmente no horário de saída, para escoar a multidão rapidamente; melhoria da iluminação pública dentro e fora das praças esportivas; perda de pontos por parte do time da torcida arruaceira, como na Itália; proibição do torcedor comprovadamente violento frequentar os estádios, ficando obrigado a prestar serviços comunitários na hora do jogo, como na Alemanha, pioneiramente (MURAD, Maurício. Futebol e violência no Brasil. In: Discursos Sediciosos, ano 1, nº 1. Rio de Janeiro: Editora Relume-Dumará, 1996. p. 117). 
violência e assumem a dança da sedução. No entanto, se por um lado há um aspecto positivo no tom jocoso das letras e na afirmação de um corpo jovem, em pleno vigor sexual, por outro, há um aspecto destruidor no "pornofunk", uma lógica guerreira, uma ressignificação de gírias que marcavam a sociabilidade masculina na fase anterior do funk. "Passar cerol", "quebrar o barraco", "dar muita pressão" e "formar o bonde" passam a marcar o confronto entre o "tigrão" e a "cachorra". A "destruição pelo prazer" se opõe ao ethos do prazer da destruição. Agora, a disputa é pelo monopólio de dar e receber prazer. Os MCs exaltam os atributos da virilidade com um tom imperativo e agressivo. ${ }^{168}$

O DJ Marlboro refuta a versão de Verônica Costa. Segundo ele, o fim do corredor veio depois que os donos das equipes mais beneficiadas foram punidos pelas autoridades, “o que já devia ter sido feito no início quando só havia dois bailes, e não quando isso estava generalizado". ${ }^{169}$ O juiz da $2^{\text {a }}$ Vara da Infância e Juventude, Guaracy Vianna, diz acreditar que 2003 foi um ano tranquilo para o funk justamente por causa do fim da hegemonia da Furacão 2000. Seja qual tenha sido a motivação, após 1999 não havia mais corredor no funk carioca. ${ }^{170}$

Os organizadores dos bailes adotam uma postura ambígua em relação às brigas. Muitos dizem que é preciso fazer alguma coisa para contê-las, mas nunca dizem o que deve ser feito. As tentativas para suprimir os bailes de embate também sempre fizeram parte do discurso de alguns organizadores, inclusive dos que mantinham, mesmo que veladamente, este componente no baile. Existe toda uma organização (a revista na porta, seguranças, a habilidade do DJ, etc.) que tenta evitar o aparecimento da violência, mas é raro um baile que não tenha pelo menos uma briga.

Briga sempre existiu, mas alguns organizadores institucionalizaram a "divisão" de territórios em seus bailes. Os DJs criticam a violência, mas, ao mesmo tempo, a estimulam, ainda que indiretamente, quando tocam os gritos de galera. Alguns organizadores interrompem o baile quando a briga alcança áreas "neutras". Paradoxalmente, quando a

\footnotetext{
${ }^{168}$ CECCHETTO, Fátima; FARIAS, Patrícia. Do funk bandido ao pornofunk: o vaivém da sociabilidade juvenil carioca. In: Interseções: Revista de Estudos Interdisciplinares, ano 4, número 2. Rio de Janeiro: PPGCS/UERJ, 2002. p. 41, 46-47, 50, 52-53.

169 Apud MEDEIROS, Janaína, op. cit. p. 58, 66. Ao declínio da Furacão 2000 correspondeu a nova ascensão do DJ Marlboro. Há uma conhecida rivalidade entre eles, por questões diversas que envolvem demarcação de território para os bailes e disputas acerca dos direitos autorais pagos aos MCs e autores de músicas. Enquanto o DJ Marlboro acusa Rômulo Costa de sugar de forma imediatista o movimento funk para ganhar dinheiro, Verônica Costa acusa o DJ Marlboro de promover um grupo fechado, elitizado, de amigos e conhecidos, gente que não é do baile, dança, briga, sobe no palco e canta (ESSINGER, Silvio, op. cit. p. 97, 257-258).

${ }^{170}$ Apud MEDEIROS, Janaína, op. cit. p. 68.
} 
briga "tá devagar", ela é incentivada. Em algumas ocasiões, parece existir até uma competição para saber qual é o baile mais violento. ${ }^{171}$

Alguns organizadores e DJs, para se justificarem, sustentam que os bailes, ao “organizarem” a briga, se constituem numa das únicas fontes de diversão para os jovens, um espaço para o extravasamento das tensões, descarregamento de emoções, uma válvula de escape para as frustrações de uma vida semanal estafante e sem perspectivas. A violência entre as galeras, assim, seria muito pior e o Rio muito mais violento se os bailes não existissem. Se não fosse o funk, a válvula de escape ia ser outra coisa, como as brigas entre torcidas organizadas. Contudo, as consequências das rixas construídas no baile, segundo o relato dos próprios integrantes das galeras, podem determinar a continuação do conflito em outros espaços, fora do baile, de forma ainda mais violenta. ${ }^{172}$ Há alguma jurisprudência a esse respeito:

\begin{abstract}
2010.050.08204 - APELAÇÃO
DES. SUIMEI MEIRA CAVALIERI - Julgamento: 01/03/2011 - TERCEIRA CÂMARA CRIMINAL

Apelação Criminal. Condenação do réu como incurso nos artigos 121, § 2?, IV do CP e artigo 121, § 2?, IV c/c 14, II, do CP (2x), na forma do artigo 69 do CP. Restou apurado nos autos e reconhecido pelo Conselho de Sentença que o apelante, após discussão em um baile, de surpresa, efetuou vários disparos de arma de fogo contra as vítimas, causando a morte de André Correia Perucio e atentando contra a vida de Jorge Mendes e Carlos José Pinheiro, no momento em que deixavam o local dos fatos e ingressavam em um táxi (...) Não se pode considerar que a mera discussão ocorrida anteriormente no baile exigiria o preparo das vítimas para um ataque imediato do agressor, mormente com a utilização de arma de fogo.
\end{abstract}

0291140-51.2008.8.19.0001 (2009.050.01909) - APELAÇÃO

DES. SIRO DARLAN DE OLIVEIRA - Julgamento: 20/10/2009 - SETIMA

CÂMARA CRIMINAL

APELAÇÃO CRIMINAL INTERPOSTA PELO ACUSADO, QUE SE INSURGE CONTRA SENTENÇA QUE JULGOU PROCEDENTE A PRETENSÃO PUNITIVA ESTATAL, E CONDENOU O RÉU A UMA PENA

\footnotetext{
${ }^{171}$ HERSCHMANN, Micael, op. cit. p. 177; VIANNA, Hermano. O mundo funk carioca. 2 ed. Rio de Janeiro: Zahar, 1988. p. 84; MINAYO, Maria Cecília de Souza et alii. Fala, galera: juventude, violência e cidadania no Rio de Janeiro. Rio de Janeiro: Garamond, 1999. p. 41, 57; CECCHETTO, Fátima. "As galeras funk cariocas: entre o lúdico e o violento". In: VIANNA, Hermano (Org.). Galeras cariocas: territórios de conflitos e encontros culturais. Rio de Janeiro: Editora da UFRJ, 1997. p. 101, 107; DAYRELL, Juarez, op. cit. p. 141.

${ }^{172}$ CECCHETTO, Fátima, op. cit. p. 111-112; VIANNA, Hermano, op. cit. p. 45; ESSINGER, Silvio, op. cit. p. 117. Informantes de Hermano Vianna relatam que quem briga já vem com a "cabeça quente" de fora do baile, que muita gente que frequenta o mundo funk não tem "educação", não quer se divertir e sim fazer "arruaça" (VIANNA, Hermano, op. cit. p. 77). Alguns jovens comentam que frequentemente já chegam irritados ao baile, decididos a brigar, seja porque passaram "a semana inteira sem beijar na boca", seja porque discutiram com suas mães. As brigas funcionam então como momento de catarse. As angústias e frustrações são tratadas com agressões aos outros, tomados como inimigos (MINAYO, Maria Cecília de Souza et alii, op. cit. p. 57).
} 
DE 07 (SETE) ANOS DE RECLUSÃO E 21 (VINTE E UM) DIAS MULTA, NO VALOR MÍNIMO LEGAL, A SER CUMPRIDA NO REGIME SEMIABERTO, PELA PRÁTICA DO CRIME TIPIFICADO NO ART. 157, $\S 2^{\circ}$, INCISO II (DUAS VEZES) DO CÓDIGO PENAL. (...) NOTADAMENTE, O ACUSADO NEGA OS FATOS DA DENÚNCIA, MAS DEPOIS AFIRMA QUE ESTAVA DE CABEÇA QUENTE, PORQUE ACHOU QUE AS VÍTIMAS TINHAM "ZOADO" DELE, E, APÓS A SAÍDA DO BAILE, "ACABOU TOMANDO O CELULAR DE UM DELES".

0014410-56.2003.8.19.0001 (2005.050.04903) - APELAÇÃO

DES. GIZELDA LEITAO TEIXEIRA - Julgamento: 29/11/2005 - QUARTA CÂMARA CRIMINAL

HOMICÍDIO - Art. 121, § $2^{\circ}$, IV e 121, § $2^{\circ}$, IV, c/c 14, II, n/f 71, todos do CP Penas de 17 anos e 06 meses de reclusão e 19 anos e 07 meses de reclusão, ambos em regime integralmente fechado. Apelantes que, em razão de rixa decorrente de brigas ocorridas em "bailes funk", efetuaram disparos de arma de fogo contra as duas vítimas, vindo uma a morrer e outra a ser atingida na perna, o que não lhe impediu de fugir de seu algoz.

0001595-86.1998.8.19.0038 (2005.050.00802) - APELAÇÃO DES. GIZELDA LEITAO TEIXEIRA - Julgamento: 30/08/2005 - SEGUNDA CÂMARA CRIMINAL

HOMICÍDIO - Art 121, §2 $2^{\circ}$, II do CP, - Pena de 12 anos e 06 meses de reclusão, regime integralmente fechado - Apelante que, no período noturno, em Japeri, Nova Iguaçu, efetuou disparos de arma de fogo contra a vítima, causando-lhe a morte. O crime em questão teve motivação fútil, eis que decorrente de banal e longínqua discussão entre apelante e vítima, ocorrida em um baile, cerca de três anos antes do presente fato delituoso.

0029051-86.2002.8.19.0000 (2002.050.03340) - APELAÇÃO

DES. MARCUS QUARESMA FERRAZ - Julgamento: 12/11/2002 TERCEIRA CÂMARA CRIMINAL

Crime contra o patrimônio. Latrocínio tentado (artigo 157. $53^{\circ}$, parte final, c/c artigo 14. inciso II, do Código Penal Recurso defensivo. Absolvição, com base no artigo 386, inciso VI. do Código de Processo Penal. Desclassificação para o artigo 157, § 2*. Inciso E. c/c artigo 14. inciso II, do Código Penal. Fixação da pena no mínimo legal. Redução no fração máxima pela tentativa. A versão do réu de que já brigara com a vítima em baile funk e, na ocasião em que foi preso, mais uma vez entraram em luta corporal, durante a qual a vítima gritou, chamado-o de "ladrão", momento em que surgiu terceira pessoa que atirou em sua perna, e que o adolescente apenas passava pelo local sem participar da briga, restou restrita ao campo das alegações, pois não ratificado por prova testemunhal.

0063515-41.1999.8.19.0001 (2002.050.00273) - APELAÇÃO

DES. NILZA BITAR - Julgamento: 02/04/2002 - QUARTA CÂMARA CRIMINAL

HOMICÍDIOS TENTADOS DUPLAMENTE QUALIFICADOS (QUATRO VEZES). Apelantes que, juntamente com o co-réu, no meio da madrugada, em razão de anteriores desavenças ocorridas em bailes "funk", ao avistarem o grupo rival, saltaram do automóvel em que se encontravam, e atiraram na direção de todos eles, não os matando porque a maioria conseguiu fugir e os que foram atingidos conseguiram socorro médico eficiente. 
Alguns organizadores de bailes ofereciam aos frequentadores, em caso de ferimento, cuidados médicos na enfermaria do clube ou a remoção para um hospital da cidade. A Furacão 2000 chegou a oferecer até seguro de vida. ${ }^{173}$ Cabe questionar, porém, se a adoção dessas medidas e a imposição de regras nas brigas constituem uma política de redução de danos, diante do fato consumado de que as galeras inevitavelmente brigarão, ou um fator que legitima, institucionaliza ou incentiva as brigas. $O$ fato é que medidas puramente repressivas, efetuadas pelo controle social formal, se mostraram muitas vezes contraproducentes, conforme se verá adiante.

\subsection{O papel dos DJs}

A música e o modo de dançar são apontados com muita frequência como um dos fatores propiciadores das brigas. Qualquer esbarrão ou pisão no pé pode gerar o início de uma briga, principalmente quando não há um pedido de desculpas. ${ }^{174}$ Às vezes os amigos dos briguentos também começam a brigar. A massa se comprime em algum canto da pista de dança, o mais longe possível da briga, o que facilita a irrupção de mais violência, assim como a atitude violenta dos seguranças, ao tentarem apartar as brigas e expulsar os brigões.

Os seguranças controlam o movimento da massa, impedindo a formação de rodas e outros grupos que ocupem muito espaço da pista, momentos mais propícios para a violência. Afinal, todos concordam que "festa com tanta gente e pouco espaço tem que ter briga". No momento culminante de intensidade do baile, milhares de pessoas pulam ao mesmo tempo, como se fossem um corpo só. ${ }^{175} \mathrm{Com}$ as mãos uns nos ombros dos outros, grupos formam trenzinhos, comuns também nos bailes de carnaval, e saem em filas correndo e pulando pelo salão. Às vezes, o trenzinho engrossa e vira um "mulão". Ocorre

\footnotetext{
${ }^{173}$ HERSCHMANN, Micael, op. cit. p. 182. Uma reportagem da época dos bailes de corredor denunciou um esquema em que motoristas de táxi ficavam de plantão esperando os feridos e moribundos para levá-los ao hospital e eximir de culpa os organizadores dos bailes (ESSINGER, Silvio, op. cit. p. 191).

${ }^{174}$ GUIMARÃES, Eloísa, op. cit. p. 184.

${ }^{175}$ VIANNA, Hermano, op. cit. p. 77-78. Muitas vezes é contratada uma equipe de seguranças profissionais que não têm nada a ver com o mundo funk. São constantes as reclamações dos dançarinos contra a violência desses seguranças que nem mesmo sabem diferenciar uma dança mais animada de uma briga, e que tratam os dançarinos com socos e pontapés, desencadeando novos conflitos. Algumas equipes contratam os dançarinos mais fortes para fazer a segurança de seus bailes, o que melhora a relação com o público. Em poucos clubes, não existe uma equipe de seguranças contratada e são as próprias turmas de dançarinos que cuidam da tranquilidade do baile (Ibid. p. 37).
} 
que os trenzinhos só têm graça porque correm em sentido contrário, trombando ou raspando uns nos outros. ${ }^{176}$

A pressão dos corpos e a repetição dos mesmos gestos formam a unidade delirante das "massas rítmicas". A descarga produzida artificialmente gera um "alívio impressionante", por um lado, mas, por outro, a ameaça de pânico, violência, destruição de tudo que fundamenta as hierarquias. Um baile vazio está condenado a ser um baile desanimado, pois falta a proximidade entre as pessoas que possibilita a formação de uma "verdadeira" massa e, consequentemente, da "descarga" de energia. ${ }^{177}$ Muitos jovens deixam entrever, em seus depoimentos, a força de atração exercida pelo grupo em circunstâncias como o ato de dançar. Quando estão na boate em grupo, acabam tendo reações que jamais imaginariam ter se estivessem sozinhos. ${ }^{178}$

No divertimento em grupo, como na religião, o indivíduo deixa de existir e passa a ser dominado pelo coletivo. Nesses momentos, apesar ou por causa das transgressões cometidas, os indivíduos escapam das exigências da "vida séria" e reafirma-se a consciência coletiva, isto é, o conjunto de valores compartilhados pela população, que confere a ela coesão e tem sua origem na solidariedade mecânica, a qual advém da semelhança e identificação entre os indivíduos. O contato direto com a fonte de energia do social, que pode ocorrer nas festas, é sempre muito perigoso. Daí a ligação estreita entre divertimento e violência. ${ }^{179}$

Quando a música que tocava nos bailes funk era instrumental, os dançarinos inventavam passinhos para preenchê-la. Quando o funk se nacionalizou, a figura do MC ganhou e a dança perdeu destaque. Muitos dançarinos migraram para os bailes de charme, uma espécie de funk mais lento, mais próximo do soul, com coreografias mais elaboradas.

\footnotetext{
${ }^{176}$ VENTURA, Zuenir, op. cit. p. 219-220.

177 VIANNA, Hermano, op. cit. p. 60-61, 79.

178 ALMEIDA, Maria Isabel Mendes de; TRACY, Kátia Maria de Almeida. Noites nômades: espaço e subjetividade nas culturas jovens contemporâneas. Rio de Janeiro: Rocco, 2003. p. 132. De acordo com Freud, "em uma multidão apagam-se as aquisições individuais, desaparecendo assim a personalidade de cada um daqueles que a integram. O inconsciente social surge em primeiro lugar e o heterogêneo se funde com o homogêneo. Diremos, pois, que a superestrutura psíquica, tão diversamente desenvolvida em cada indivíduo, acaba destruída, aparecendo despida uma uniforme base inconsciente comum a todos (...) O simples fato de [os indivíduos] estarem transformados em uma multidão os dota de uma espécie de alma coletiva. Esta alma os faz sentir, pensar e agir de uma maneira por completo distinta de como sentiriam, pensariam e agiriam cada um deles isoladamente". Já Sándor Ferenczi destaca que "na multidão, o homem converte-se em criança, sente-se irresponsável pelas ações, em relação às quais somente o líder, investido de um poder quase paternal, assume a responsabilidade" (Apud SHECAIRA, Sérgio Salomão. Importância e atualidade da Escola de Chicago. In: Discursos Sediciosos: crime, direito e sociedade, v. 9/10. Rio de Janeiro: Freitas Bastos, 2000. p. 157).

${ }^{179}$ DURKHEIM, Émile. Da divisão do Trabalho Social. São Paulo: Martins Fontes, 1995. p. 39 et seq. Sobre a relação entre religião, festa e violência, cf. VIANNA, Hermano, op. cit. p. 51 et seq.
} 
$\mathrm{Na}$ fase dos bailes de corredor, a dança perdeu ainda mais espaço e o axé music da Bahia conquistou muita gente que gostava de dançar coreografias, fazendo com que abandonassem os bailes funk. ${ }^{180}$

Ainda na década de 80, o DJ Fernandinho, um partidário do charme, defendia que o tipo de música que passou a dominar os bailes funk era um dos principais causadores do "aumento" da violência. Argumentava que, antes da invasão hip hop, suas festas eram pacíficas e ordeiras, mas que o público de então atuava como verdadeiros "selvagens" e suas coreografias pareciam "danças de índio". Em Salvador, durante o carnaval de 87, várias pessoas relataram a Hermano Vianna que a violência nas ruas diminuiu com o aparecimento de novos ritmos e novas danças mais calmas e "sensuais", como o fricote, o ti-ti-ti ou a "dança da galinha". O frevo de antes exigia que as pessoas pulassem de maneira enérgica, batendo em quem estivesse ao redor. Vianna, no entanto, não tinha dados para afirmar se a violência realmente havia diminuído. ${ }^{181}$

Para a festa produzir um clima excitante e/ou bem-humorado, é necessário haver uma sintonia entre os movimentos corporais, as letras e o ritmo da música. $\mathrm{O}$ comportamento no baile é, portanto, em grande medida, orientado pelas músicas. Geralmente, os principais sucessos dos bailes de corredor não são os raps românticos, melosos, que indicam o momento mais apropriado da paquera, e sim os funks com as batidas mais fortes e marcadas, as chamadas montagens ou "pancadões", trilha sonora ideal para a pancadaria. Quando os DJs tocam os "pancadões", os jovens formam os "bondes", se deslocam pelo salão, invadem o território da galera rival e a briga se intensifica no ritmo da música. Essas montagens explosivas, que constituíam apenas parte da programação do baile normal, começaram a predominar nos bailes de corredor.

As montagens geralmente são colagens de sons e ruídos. Possuem apenas refrões, cantados em coro, que remetem aos bordões entoados pelas torcidas organizadas de futebol nos estádios ou pelas galeras, quando se encontram para brigar. Eles exaltam os nomes das comunidades, contêm xingamentos que procuram desqualificar ou intimidar os "bondes alemães", fazem referências às organizações criminosas, revelam quem são as outras

\footnotetext{
${ }^{180}$ MACEDO, Suzana. DJ Marlboro na terra do funk - Bailes, bondes, galeras e MCs. Rio de Janeiro: Dantes Livraria e Editora, 2003. p. 86. Por outro lado, conforme visto acima, Verônica Costa afirma que, inspirada no sucesso do axé, colocou aos poucos músicas com coreografias para acabar com as brigas nos bailes de corredor.

${ }^{181}$ VIANNA, Hermano, op. cit. p. 84-86. Mister Paulão era outro DJ desiludido com a predominância do hip hop e da violência nos bailes (Ibid. p. 39).
} 
galeras que formaram "o bonde" e, indiretamente, se as galeras estão "fortalecidas" ou "humildes". 182

Hermano Vianna alega que a violência não é culpa do funk e que as galeras continuariam fazendo arrastões mesmo se frequentassem bailes onde tocasse valsa. O DJ Marlboro, por sua vez, afirma que "a culpa dos tumultos nos bailes não é da música, mas, sim, dos baderneiros". ${ }^{183}$ Não se deve ser determinista e tomar o funk como a "própria origem da violência e não apenas como cenário eventual". Assim como ocorreu com o rock, nos anos 50, reportagens nos jornais e cartas dos leitores "atribuíam à música um poder demoníaco, capaz de levar os jovens a práticas antissociais." 184

Se não causa as brigas, o estilo musical pode, todavia, ser considerado um fator facilitador. O DJ tem, pois, um poder enorme nas mãos: o de controlar conscientemente a intensidade da festa. ${ }^{185}$ Ele tanto pode animar, provocar um clima de euforia, como desanimar, esfriar as galeras. É possível observar melhor o poder do DJ nos momentos em que estoura uma briga mais violenta e o baile ameaça sair do controle. Uma das estratégias é iniciar uma sessão "rala-rala", só com músicas românticas, lentas e melosas, para esfriar o baile, acabando com as brigas, e esquentar os casais, incentivando encontros amorosos e restaurando a ordem. Se não fossem essas intervenções, os bailes poderiam se tornar muito mais violentos. ${ }^{186}$

Para que o baile se realize plenamente, mesmo o de corredor, é preciso que o DJ orquestre elementos como excitação e controle, competição e comunhão, brigas e carícias. Ele sabe que as galeras desenvolvem o ritual de luta literalmente no ritmo da música e, assim, "esfria" em certos momentos o baile a fim de garantir seu bom andamento e facilitar o trabalho dos seguranças. ${ }^{187}$ Achar o ponto de equilíbrio é muito difícil, pois a maior

182 HERSCHMANN, Micael, op. cit. p. 159-160; CECCHETTO, Fátima, op. cit. p. 101, 108-109; DAYRELL, Juarez, op. cit. p. 128; CARRANO, Paulo César Rodrigues. Os jovens e a cidade: identidades e práticas culturais em Angra de tantos reis e rainhas. Rio de Janeiro: Relume Dumará, 2002. p. 67-68; DEBATE 7 - Organizações comunitárias, cultura popular e violência II. In: ALVITO, Marcos; VELHO, Gilberto. Cidadania e Violência. Rio de Janeiro: UFRJ e FGV, 1996. p. 346-347.

${ }^{183}$ Apud ESSINGER, Silvio, op. cit. p. 126, 128.

${ }^{184}$ RIBEIRO, Manoel, op. cit. p. 288.

185 VIANNA, Hermano, op. cit. p. 22. Os dançarinos dos bailes não entram em transe, mas há semelhanças entre a relação de poder que o DJ estabelece com seu público e a relação do músico que toca atabaque num ritual de candomblé com os dançarinos que vão ser possuídos pelos espíritos (Ibid. p. 62). Um jovem informante declarou a Carrano que "a galera fica azuretada com a música e sai na porrada" (CARRANO, Paulo César Rodrigues, op. cit. p. 64).

${ }^{186}$ VIANNA, Hermano, op. cit. p. 80. "Nós fazemos o que o maestro faz, que é reger as músicas que vão tocar nos bailes. Tem hora que cresce... tem hora que tem que dar uma diminuída, uma freada... Senão as pessoas ficam doidas... e acabam pisando no pé da outra e pode sair confusão..." (MACEDO, Suzana, op. cit. p. 9). Cf. também ESSINGER, Silvio, op. cit. p. 116.

${ }^{187}$ HERSCHMANN, Micael, op. cit. p. 152. 
satisfação para um DJ é ver o público "delirando". Como uma euforia descontrolada pode desencadear brigas, existe sempre um conflito entre o DJ e as pessoas encarregadas da segurança do baile, que o pressionam para "espalhar" as músicas de grande sucesso e mais animadas ao longo do baile ao invés de concentrá-las no final ou até para excluir do seu set músicas consideradas “perigosas”, principalmente quando o público já é violento. ${ }^{188}$

Os organizadores dos bailes estão sempre atentos a qualquer sinal de algo que possa vir a perturbar a "tranquilidade" do baile, mas todos reconhecem sua impotência, pois é impossível manter a calma no baile sem destruir o que ele tem de melhor: a euforia, a diversão explosiva, o delírio das massas. Outros DJs dizem que, mais do que o estilo de música tocado, tudo depende da vontade e do esforço pedagógico dos organizadores do baile, que podem tirar proveito financeiro dos bailes violentos ou incentivar a cultura de paz, interromper o baile para dar broncas, expulsar baderneiros e "ensinar" a massa a se comportar adequadamente, apelando para a honra e para a honestidade da maioria dos dançarinos. Por mais que haja uma perda do público que gosta de brigar, aqueles que não querem brigar acabam trazendo para o baile pessoas do mesmo perfil. ${ }^{189}$

\subsection{O aspecto lúdico do baile de corredor}

É preciso salientar que mesmo o baile de corredor não é um território sem lei. A invasão do território do "alemão" é quase sempre controlada pelos seguranças que, além da enorme massa física e da habilidade em artes marciais, contam muitas vezes com armas brancas como instrumento de intimidação. Esses "mediadores do combate" procuram evitar que qualquer dos meninos seja arrastado para o território das galeras rivais. Introduzem-se constantemente entre os lutadores para separá-los e realinhá-los novamente no corredor quando passam dos limites ou não respeitam as regras. Dois ou três seguranças supervisionam 50 a 100 garotos em um baile, sem serem atingidos por um soco sequer.

\footnotetext{
${ }^{188}$ VIANNA, Hermano, op. cit. p. 44-45, 81. O DJ Marlboro chegou a acatar essas recomendações da equipe de som, mas as brigas continuaram e o baile voltou, pouco a pouco, a ser o que era antes (Ibid. p. 81-82, 85). Uma música teria provocado a aparição do diabo no baile do Clube Vera Cruz, ficou conhecida como a música do incorporado e os DJs de todos os bailes da capital foram devidamente orientados para não tocá-la (CARRANO, Paulo César Rodrigues, op. cit. p. 68). Cf. também HERSCHMANN, Micael, op. cit. p. 151.

${ }^{189}$ VIANNA, Hermano, op. cit. p. 45, 84-86; ESSINGER, Silvio, op. cit. p. 190-191; SALLES, Lúcia (Org.). DJ Marlboro: o funk no Brasil - por ele mesmo. Rio de Janeiro: Mauad, 1996. p. 43; HERSCHMANN, Micael, op. cit. p. 152-153. Manoel Ribeiro sustenta que é com "bico, luz e som” que se administra um baile funk: acendendo a luz, mudando o ritmo do som e usando a conversa (Apud VENTURA, Zuenir, op. cit. p. 223).
} 
Os seguranças são muito respeitados pelas galeras, não só por sua força e truculência, mas principalmente porque ninguém quer ser descartado do jogo. Muitos esperam por aquele momento toda a semana. Quando eventualmente um dos garotos não respeita as regras e é arrastado para fora do baile pelos seguranças, entra em cena um dos líderes das galeras, em geral o mais diplomático e carismático, para negociar com o segurança sua permanência no baile. Ele e o líder mais destemido do grupo determinam o momento de a galera avançar ou recuar obedientemente, o momento de "zoar" ou não, seja no baile, ônibus, praia ou outros lugares. ${ }^{190}$

A revista na entrada do baile é muito minuciosa para impedir que as galeras entrem com armas que possam causar problemas mais sérios durante as brigas. ${ }^{191}$ No fundo, tudo parece ser um grande jogo. As paredes do corredor são formadas por pessoas de mãos dadas ou braços entrelaçados. O jogo consiste em desferir golpes rápidos no outro lado, com os pés ou com as mãos, de tal maneira que o combatente possa voltar logo ao seu campo. Se escorregar, cair no território inimigo e não for arrastado a tempo, ele corre o risco de ser trucidado.

Usando os pés, o combatente terá sempre a proteção dos companheiros, seguro pelos braços. Já os golpes de mão são mais perigosos, pois exigem desprender-se dos aliados. Mais ousado ainda é penetrar no território inimigo e sequestrar alguém que será espancado ou humilhado no território de base. Cabe à galera que teve o seu integrante sequestrado mobilizar-se para o resgate. Neste jogo em que a violência é ritualizada, cada

190 HERSCHMANN, Micael, op. cit. p. 136-138, 173-174; VIANNA, Hermano, op. cit. p. 36; CECCHETTO, Fátima, op. cit. p. 99-100, 107; DAYRELL, Juarez, op. cit. p. 128. Aparentemente, existem poucos níveis hierárquicos na galera. Em geral, toda galera tem dois líderes com diferentes áreas de atuação. O primeiro é uma espécie de "embaixador", representante oficial da galera junto aos organizadores do baile e outras galeras. Sua função é negociar a integração nos bondes, articular, junto aos organizadores, a participação da galera nos festivais de galeras e intervir de modo a evitar ou minimizar a penalização do grupo ou de um membro dele em caso de infração nos bailes. Já o segundo líder é uma espécie de "grande guerreiro", que impõe respeito nos embates que possam ocorrer nos bailes e na cidade. Nos bailes de "corredor", sua atuação é mais marcante e é ele quem decide o posicionamento de cada membro no confronto. Se ele for ferido, assume temporariamente a sua posição o integrante mais forte ou o mais velho do grupo para garantir que o grupo não venha a ter o seu prestígio abalado junto às galeras rivais (HERSCHMANN, Micael, op. cit. p. 167-168) Alguns se referem ao chefe como o dono da galera, diretor e comando de frente (GUIMARÃES, Eloísa, op. cit. p. 80-81).

${ }^{191}$ Vianna informa, contudo, que não existia, até o final de 86, nenhum tipo de fiscalização no corredor que vai do bar para a pista de dança. As garrafas podiam ser transportadas livremente e podiam servir de armas (VIANNA, Hermano, op. cit. p. 75-76). Minayo et alii relatam que as armas usadas para o ataque nos bailes de corredor são pedaços de canos, de madeira, correntes e, segundo dizem, "agora arrumaram até um aparelhinho de choque" (MINAYO, Maria Cecília de Souza et alii, op. cit. p. 57). Já Herschmann, em sua pesquisa de campo, no final dos anos 90, constatou que há o cuidado para que nada se transforme numa arma nas mãos dos garotos. Nenhum objeto de vidro, como uma garrafa, era deixado no balcão do bar. Todos bebiam em copos de plástico (HERSCHMANN, Micael, op. cit. p. 140). 
um dos membros precisa do apoio da sua galera. Há fortes laços de solidariedade e companheirismo permeando a conduta destes grupos.

Durante muito tempo alguns indivíduos simulam a situação de briga, sem que a briga realmente aconteça. Quando os seguranças interrompem a luta ao se postarem entre as galeras, elas passam a se provocar, dando chutes no ar e refugando. A violência, em muitos aspectos, longe de representar um fator de afastamento da participação no baile, funciona como um estimulante. Nessa luta não se usa qualquer tipo de arma, a não ser as mãos vazias e os pés calçados de tênis. Talvez isso explique o fato de que, mesmo após horas de combate, não seja comum ver-se um combatente sangrando. ${ }^{192}$ Talvez até porque saibam que há um controle, uma "administração" da briga, esses jovens se entreguem tão plenamente ao jogo, à luta.

Além disso, na ritualização da violência nos bailes funk, os grupos não visam à eliminação propriamente do inimigo, cuja permanência parece garantir o clima de excitação e competição, mas o reconhecimento de um território. A participação no jogo compensa um cotidiano que, em geral, os exclui. ${ }^{193}$ Tudo é muito arriscado, mas extremamente excitante. O ritual de embate pode ser uma importante válvula de escape para estes jovens e ser comparado a uma espécie de jogo perigoso, a uma modalidade de esporte radical dos segmentos privilegiados da população da cidade, como o kickboxing ou o jiu-jítsu. ${ }^{194}$

Tal como nesses esportes, a violência poderia ser regulamentada para tornar-se segura e não ferir ninguém. As lutas aconteceriam em uma arena maior e os lutadores contariam com equipamentos de proteção. ${ }^{195}$ Pode-se até afirmar que essa violência tornarse-ia, juridicamente, um exercício regular de direito, excludente de ilicitude. Resta saber se o combate teria a mesma graça para as galeras, dado que o "gostinho pelo proibido" faz parte tradicionalmente de determinadas subculturas.

Não se pode esquecer que a capoeira, mistura de luta e dança dos ex-escavos negros, foi criminalizada no Código de 1890 e que as brigas dos bailes de corredor encontram muitas semelhanças com ela. Ambas são coreografias violentas e ritualizadas.

\footnotetext{
192 VENTURA, Zuenir, op. cit. p. 122-123; CARRANO, Paulo César Rodrigues, op. cit. p. 64; HERSCHMANN, op. cit. p. 136-138, 159-160.

${ }^{193}$ HERSCHMANN, Micael, op. cit. p. 174-175.

${ }^{194}$ Ibid. p. 142. Depois das brigas, vários jovens chegaram excitados, demonstrando um prazer visível ao comentar casos de chutes e murros dados ou recebidos. Não deixa de ser uma forma de eles descarregarem emoções, além de reproduzirem uma cultura masculina baseada na valentia e na coragem (DAYRELL, Juarez, op. cit. p. 141).

${ }^{195}$ VENTURA, Zuenir, op. cit. p. 121; ARCE, José Manuel Valenzuela, op. cit. p. 106-107.
} 
Ao contrário do que ocorre nas brigas de hooligans, na fisionomia dos "jovens guerreiros", que extravasam a agressividade, não há ódio, mas satisfação, excitação, sorrisos ou um ar de deboche. No fundo, eles estão "brincando". O humor é um aspecto lúdico bastante ativo nos bailes. O "grotesco" é uma referência estética fundamental. Não basta enfrentar a galera rival, é preciso "zoar" dela. ${ }^{196}$

Os jovens comentam que durante as brigas sentem medo, mas o momento de espera pelo conflito gera prazer e serve como pano de fundo para as "paqueras". As agressões frequentemente sofridas deixam cicatrizes, mas não desestimulam o retorno dos grupos. Questionados se tal situação vale a pena, as respostas são afirmativas, enfatizando que "quanto mais apanhar, mais você vai querer brigar" e que são "viciados em briga". A excitação da violência suplanta o temor das dores físicas. A "falta de outras opções" de lazer alegada pelos jovens se junta a um sentimento de aventura próprio da idade, que se escoa para uma brincadeira muito agressiva. ${ }^{197}$

Muitos abandonam suas namoradas e vão aos bailes para brigar. Para algumas galeras e outros tantos grupos juvenis subculturais, as brigas representam uma forma de curtir, uma grande aventura, fonte de emoção e de excitação inerentes à adolescência. ${ }^{198}$ O prazer do confronto e a emoção de ver a cara do "alemão" não se encontram nos bailes que não têm briga. Para muitos desses jovens, baile sem briga e "alemão" não tem “zoação" nem graça. ${ }^{199}$ Se essas "brincadeiras", danças e jogos são violentos, deve-se considerar que

196 HERSCHMANN, Micael, op. cit. p. 136, 159-160; VENTURA, Zuenir, op. cit. p. 125. Para o DJ Marlboro, crítico dos bailes de corredor, "a imprensa não entende o que os funks chamam de embate. Durante o baile, há um contato físico muito forte entre os que vão para a pista dançar. É um contato que obedece a certas regras e que não é, de forma alguma, violento. É uma coisa parecida com a capoeira, onde não se vê raiva e sim todo um movimento marcado pela ginga e pela alegria" (ESSINGER, Silvio, op. cit. p. 132). Algumas músicas do baile sugerem uma violência ritual. É o caso de uma que lembra o toque do berimbau do jogo da capoeira. Logo nos primeiros acordes os jovens, muitos verdadeiramente praticantes da capoeira, iniciam a ginga (CARRANO, Paulo César Rodrigues, op. cit. p. 67-68).

${ }^{197}$ MINAYO, Maria Cecília de Souza et alii, op. cit. p. 57-58. Os jovens de classe média que colocaram fogo em um mendigo declararam que queriam apenas fazer uma "brincadeira".

${ }^{198}$ GUIMARÃ̃ES, Eloísa, op. cit. p. 185-186. MINAYO, Maria Cecília de Souza et alii, op. cit. p. 57.

${ }^{199}$ CECCHETTO, Fátima, op. cit. p. 97, 108. Cf. ESSINGER, Silvio, op. cit. p. 164; HERSCHMAN, Micael, op. cit. p. 142. "O que ocorre dentro do baile- os limites e a ausência de limites que definem a economia da guerra - é tratado como recurso legítimo e motor do desejo de lá estar e do prazer (para alguns) em ir de bonde. Para outros, bater e apanhar são situações que fazem parte de um jogo, cujas regras são definidas pela origem da galera, pelo rosário de alianças que uma espécie de adscrição territorial implica, pela fidelidade aos amigos da galera, pela imagem e fama daqueles que 'têm disposição' entre as meninas e, sobretudo, pelo prazer em participar do 'baile de briga'. Mais uma vez o prazer de zoar" (CUNHA, Olívia M. G. "Conversando com Ice-T: violência e criminalização do funk". In: HERSCHMANN, Micael (Org.). Abalando os anos 90: funk e hip-hop - globalização, violência e estilo cultural. Rio de Janeiro: Rocco, 1997. p. 107). 
o jogo não se constitui como um espaço social de suspensão da realidade cotidiana, tal como a atividade lúdica é apresentada nas análises idealistas. $\mathrm{O}$ jogo nasce da realidade das condições de vida que traduzem o mundo no presente (Elkonin, 1985). Nas práticas culturais da juventude se pode compreender que determinadas relações, consideradas simplesmente como violentas, são verdadeiros jogos rituais referidos às condições de vida social dos jovens que os põem em movimento. As brigas entre as galeras nos bailes funk não se constituem como uma esfera dissociada do ritual de brincadeira da festa. É nesse sentido que se pode afirmar que os jovens participantes dos bailes funk não apenas oscilam entre o lúdico e o violento (Ceccheto, 1997), mas vivem uma realidade de violência social que os impulsionam para a realização de também violentas formas lúdicas de sociabilidade. ${ }^{200}$

Ainda que as galeras não estejam necessariamente vinculadas às quadrilhas, no baile percebe-se "a representação simbólica de processos complexos que organizam a vida social das favelas, segundo uma lógica antagônica, territorial e guerreira", uma recriação dos códigos de violência no âmbito do lazer e da sociabilidade juvenil. ${ }^{201}$ A violência cotidiana que toma conta da periferia do Rio de Janeiro imprimiria sobre esses jovens um modelo violento de se divertir. Os conflitos do baile são "uma maneira de o cara aparecer", de "ser alguém". 202

O lazer é um momento privilegiado para os jovens afirmarem laços de amizade, desenvolverem sua criatividade e confrontarem-se consigo mesmos. Cabe ao Poder Público investir em alternativas de lazer para a juventude das periferias e favelas, cujas possibilidades de entretenimento é são muito mais escassas, pobres e controladas (pela igreja, família e polícia). Para muitos desses jovens, "lazer e violência se misturam em proporções elevadas, criando-se assim uma cultura de inter-relação humana e social perpassada muito mais pela medição de força física do que pelo cultivo do diálogo". ${ }^{203}$

Um dos objetivos das galeras, gangues e várias outras organizações juvenis é justamente explicitar a violência dissimulada do sistema. ${ }^{204}$ Uma sociedade violenta dissemina uma cultura da violência, que se reflete em seus jogos, danças e "brincadeiras".

\footnotetext{
${ }^{200}$ CARRANO, Paulo César Rodrigues, op. cit. p. 65.

${ }^{201}$ CECCHETTO, Fátima, op. cit. p. 114

${ }^{202}$ GUIMARÃES, Eloísa, op. cit. p. 183.
}

${ }^{203}$ MINAYO, Maria Cecília de Souza et alii, op. cit. p. 60. Muitos rapazes assumem a violência nas relações interpessoais e entre grupos rivais como normais, evidenciando que o seu exercício é parte de sua vida e de sua dinâmica social (Ibid. p. 183).

${ }^{204}$ Ibid. p. 103. "Nessa cultura da violência convém lembrar que ela não se limita apenas ao emprego da força física, mas também à possibilidade ou à ameaça de empregá-la. Deve-se associar também a violência à ideia de poder, à possibilidade de alguém impor sua vontade ou intenção sobre o outro. Assim, o aumento da violência da nossa sociedade não está hoje apenas na desigualdade econômica, mas também se alia ao esvaziamento de conteúdos culturais. Isoladamente, a pobreza não pode ser considerada a única responsável pela perda de referências éticas que sela a convivência social entre grupos e indivíduos" (CARMO, Paulo Sérgio do. Culturas da rebeldia: a juventude em questão. São Paulo: Editora SENAC, 2001. p. 213). A violência nos bailes é muito mais resultado, e não causa, da violência social (Ibid. p. 220). 
A violência no futebol, por exemplo, apenas dá visibilidade a um processo geral de desagregação social mais ampla, no qual todas as instituições brasileiras estão mergulhadas e que cria condições propícias à violência. Na segunda década do século XX, os negros não podiam esbarrar nos jogadores brancos, sob pena de os outros jogadores e até policiais baterem no infrator, enquanto os brancos eram, no máximo, expulsos de campo. Esta redução dos espaços, subproduto de sua situação social, obrigou os negros a jogarem com mais ginga, evitando o contato físico e inventando o drible, um futebol que "lembra passos de dança e fintas de capoeira".

No passado, as torcidas eram "instituições familiares e coreográficas" carnavalizadas, que, apesar de embates esporádicos, marcavam sua atuação com cânticos, ritmos, alegorias e festejos. As torcidas organizadas violentas surgiram na década de 1970, auge da ditadura militar, seguindo as doutrinas e os padrões de organização do militarismo então vigente: visão de mundo intolerante, competitividade selvagem, antagonismo repressor, invasão territorial, eliminação das diferenças pelo uso da força. Os confrontos passaram a agudos, programados, generalizados e institucionalizados.

Estas torcidas se estruturam em "pelotões", “destacamentos", “esquadrões", "tropas-de-choque", "comandos", "exércitos", "facções de gladiadores" e muitas são treinadas em artes marciais. Seus líderes são chamados "capitães", "tenentes", "sargentos". Seus cantos são cantos de guerra. Seus símbolos, comportamentos grupais e relações de poder hierárquicas são militares. Dividem as grandes cidades em territórios dominados, cujas fronteiras são demarcadas por grupos de ação e força. A violência estrutural e a crise permanente da década de 90, por sua vez, potencializaram a emergência de atitudes antissociais e acrescentaram à história das torcidas organizadas uma infraestrutura bélica, com tecnologia avançada na fabricação de armamentos, bem como a articulação com setores marginalizados da vida urbana brasileira. ${ }^{205}$

\subsection{Os concursos de galeras}

Norbert Elias destaca como, na sociedade de corte, a monopolização da violência pelas autoridades centrais reduziu os níveis de agressividade manifesta em relações sociais normais. Para conseguir favores dos superiores e se diferenciar dos inferiores na escala social, eram necessárias realizações culturais, maneiras e linguagem refinadas,

\footnotetext{
${ }^{205}$ MURAD, Maurício, op. cit. p. 110 et seq.
} 
demonstrações de civilidade e sofisticação. Na sociedade do século XVIII e XIX, os padrões culturais da aristocracia se estenderam para a alta burguesia, que, em virtude da disciplina do mercado e da vida e religião ascéticas, já tinham desenvolvidas as tendências de autorrestrição dos impulsos e renúncia aos instintos. Passou-se a coibir no espaço público, pela força da lei ou pela prudência social, demonstrações abertas de agressividade, emoções espontâneas de qualquer espécie, manifestações dos instintos animalescos humanos referentes à sexualidade, violência, embriaguez, escatologia, etc.

Em um primeiro momento, esse refinamento das maneiras e a sensibilidade para com os sentimentos dos outros são um sinal do respeito aos superiores na escala social e assumidos conscientemente e de forma instrumental como um ato de deferência a um poder superior, da mesma forma como se renuncia primeiramente à violência em reconhecimento à superior força das armas do príncipe. Todavia, conforme são passados de geração em geração, esses modos de comportamento gradualmente perdem seu aspecto instrumental e se tornam modos de comportamento os quais os indivíduos sentem que são corretos por si só. ${ }^{206}$

Zaluar destaca que, apesar das semelhanças, inexiste nas gangues o aspecto festivo das galeras, cuja atividade principal não é a luta, mas o baile. Esse aspecto festivo é próprio de outras manifestações populares do Rio de Janeiro, nas quais a catarse das emoções, inclusive da rivalidade e do orgulho masculino, faz-se de modo competitivo, porém regrado. O processo civilizador é retomado nos bailes através dos concursos, do estabelecimento das regras de convivência e da "apresentação controlada do agonismo entre pessoas e grupos". 207

Não é à toa que os bailes de corredor são comparados a esportes radicais. As práticas esportivas instituíram uma representação simbólica da competição entre segmentos, facções e até Estados-Nações, tornando-a não violenta e não militar, visto que suas regras acordadas excluíam a possibilidade de que algum contendor fosse seriamente ferido. Na sociedade assim pacificada, o monopólio legítimo da violência pelo Estado foi efetivado por modificações nas características pessoais de cada cidadão, como o controle das emoções e da violência física, o fim da autoindulgência excessiva, a diminuição do prazer de infligir dor ao alheio etc.

\footnotetext{
${ }^{206}$ Apud GARLAND, David. Punishment and modern society: a study in social theory. Chicago: Oxford University Press, 1993. p. 216 et seq.

207 ZALUAR, Alba, op. cit. p. 47 et seq.
} 
O processo civilizador, porém, não atingiu na mesma intensidade todas as classes sociais nem todos os países. Onde o Estado é fraco, um prêmio é colocado nos papéis militares. Onde os laços familiares ou locais são mais fortes, o que acontece em bairros populares, o orgulho e o sentimento de adesão ao grupo diminuem a pressão social para o controle das emoções e da violência física, resultando em baixos sentimentos de culpa no uso aberto da violência para resolver conflitos. A habilidade para lutar, em algumas galeras, é a chave para o status e o prestígio do jovem.

No Brasil, além do esporte, também foi importante para a pacificação dos costumes a instituição de torneios, concursos e desfiles carnavalescos envolvendo bairros e segmentos populacionais rivais. Desde o início do século XX, as competições entre vizinhanças pobres eram representadas em locais públicos que reuniam pessoas vindas de todas as partes da cidade, de todos os gêneros, de todas as idades, "criando sociações, ligações, encenações metafóricas e estéticas das suas possíveis desavenças, seguindo regras cada vez mais elaboradas". 208

Uma das formas tentadas para diminuir a violência nos bailes foram justamente os concursos de galeras. Trata-se de uma tentativa de cooptar as galeras, usar a rivalidade existente entre elas de uma forma positiva. Os concursos ou festivais de galeras combinam a estrutura de torneios esportivos com algumas atividades das escolas de samba e incluem competições de várias naturezas: o melhor rap, o melhor MC, o melhor DJ, rei e rainha do baile, o melhor grito de galera, o melhor striptease, a melhor coreografia, a melhor torcida, dentre outras.

Os jovens participam dos concursos na esperança de adquirir vantagens tanto materiais quanto simbólicas, distribuídas pelos organizadores, como dinheiro vivo, bailes gratuitos, "ganhar" um baile a ser realizado na comunidade, carreira de MCs, prestígio e consideração, possibilidade de ser reconhecido em "suas" favelas, transporte para as galeras, entre outras. O transporte é garantido mediante o pagamento do ingresso

\footnotetext{
${ }^{208} \mathrm{O}$ samba era uma atividade de lazer frequentada por toda a família. A cidade era representada como espetáculo ao mesmo tempo da rivalidade e do encontro dos diferentes segmentos em que ela sempre esteve dividida. Hoje, com o esfacelamento das associações e da família, ela não vai mais junta ao samba e o funk não junta gerações diferentes no mesmo espaço (ZALUAR, Alba, op. cit. p. 38-40). A violência dentro e fora dos estádios, por sua vez, contribui para afastar as famílias dos campos e desagregar a natureza de congraçamento comunitário, de festa e arte, de espaço público de lazer, que o futebol representa. O futebol, todavia, tem muito de teatralidade, de troca, de reciprocidade ente ator e plateia. Se os torcedores não comparecerem, a relação mítica fica esgarçada e isto contribui para a quebra da consistência mágica do espetáculo (MURAD, Maurício, op. cit. p. 113).
} 
antecipado do baile e fruto de acordo entre os organizadores dos bailes e as empresas municipais.

Trafegar nos ônibus das galeras é importante para a segurança dos funkeiros e a ausência de transporte impede que muitos jovens venham ao baile, pois voltar a pé ou dormir nas calçadas os torna mais vulneráveis à violência e aos perigos da rua. Por outro lado, são frequentes, antes e depois dos bailes, as brigas, apedrejamentos e tiros nos ônibus que transportam as galeras, quando passam estrategicamente por áreas rivais. Nesses casos, a galera pode ser punida com a suspensão do ônibus para o baile seguinte, a diminuição de pontos nos concursos e até a expulsão dos integrantes considerados nocivos ao funcionamento da festa.

As regras dos concursos são previamente definidas pelos organizadores junto a representantes das galeras por eles recrutados, que desempenham atividades burocráticas na organização do festival, o que exigiu o desenvolvimento de padrões hierárquicos antes inexistentes entre os jovens e os organizadores do circuito funk. Não é possível afirmar, porém, que os concursos de galera sejam um elemento totalmente novo na tentativa de suprimir a violência nos bailes. ${ }^{209}$

Já no início dos anos 70, o DJ Afrika Bambaataa, um dos criadores do hip hop, propôs que as gangues do bairro do Bronx, em Nova York, resolvessem suas rixas através da competição poética, musical e, principalmente, da dança break. ${ }^{210} \mathrm{Na}$ década de 80 , a equipe de som Soul Grand Prix trabalhava com alguns dançarinos que eram designados chefes de turma. Eles se responsabilizavam por seu grupo de amigos e participavam das reuniões da equipe de som com a diretoria do clube, discutindo aumentos nos preços das entradas e qualquer outro problema que houvesse no baile. Havendo uma briga, toda a turma podia ser impedida de entrar no baile seguinte. O DJ Marlboro tentou ainda nesta década fazer concursos entre os grupos de dançarinos, premiando as turmas mais animadas e que brigassem menos, mas o desinteresse da equipe não levou o projeto adiante. ${ }^{211}$

Rômulo Costa, no entanto, diz que a sugestão do concurso de MCs foi do então vice-governador do Rio, Nilo Batista. A ideia era pegar os garotos das favelas e dos bairros pobres, que frequentavam os bailes, e estimulá-los a escrever seus próprios raps, mostrar que podiam ser artistas. Os festivais de galeras objetivavam atrair mais cabeças para o

${ }^{209}$ CECCHETTO, Fátima, op. cit. p. 100 et seq., 112; HERSCHMANN, Micael, op. cit. p. 149 et seq.; DAYRELL, Juarez, op. cit. p. 129; CUNHA, Olívia M. G., op. cit. p. 118.

${ }^{210}$ CARMO, Paulo Sérgio do, op. cit. p. 180-181.

${ }^{211}$ VIANNA, Hermano, op. cit. p. 86-87. 
baile, evitar as brigas e satisfazer o próprio instinto de competição inerente à adolescência. $^{212}$ Foram nesses concursos de MCs que se tornaram hegemônicas as letras pedindo a paz nos bailes, afirmando o orgulho de ser funkeiro e louvando as comunidades, a ponto de alguns MCs afirmarem que conseguiram acabar com a violência nos bailes. ${ }^{213}$

Há quem diga, todavia, que os concursos acentuaram ainda mais o clima de rivalidade entre as galeras, aumentaram, consequentemente, a violência no baile e a melhor opção foi acabar com eles. ${ }^{214}$ As fronteiras entre o jogo e o conflito, entre a competição e a destruição, tornam-se difusas. Nos concursos, parece que as galeras mais "brigonas", que “prejudicam" o funk, são também as que mais se destacam, as mais prestigiadas pelas suas "proezas", em virtude do próprio código de honra dessa subcultura. Ocorre muitas vezes uma coexistência entre o ethos "brigão" e um ethos "da paz" no mesmo jovem e na mesma galera, dependendo do momento do baile e do interlocutor do funkeiro. ${ }^{215}$

\subsection{A afirmação do ethos de virilidade e a glamorização da violência}

Shecaira aponta para os efeitos envolventes e persuasivos que a imprensa, o cinema, o rádio e a televisão têm sobre a delinquência juvenil. Casos de crimes, tratados de forma sensacionalista pela mídia, são ocasional e rapidamente reproduzidos por outras pessoas que se espelham no "sucesso" encorajador do ato criminal. Os meios de comunicação não são apenas um espelho da realidade, mas intervêm na realidade, fazem parte do processo de socialização do indivíduo, formam os valores da sociedade,

212 ESSINGER, Silvio, op. cit. p. 98. Deize Tigrona, por sua vez, dá crédito ao DJ Duda pelo enfraquecimento dos bailes de corredor e criação de um celeiro de talentos na Cidade de Deus. Ao ver que suas montagens de briga não tiravam o público do Country Clube da Praça Seca, o DJ Duda resolveu anunciar, durante um baile vazio no Coroado, em 1996, que produziria quem levasse uma letra ao palco. Deize formou com mais quinze meninas da Cidade de Deus o Bonde do Fervo e foi até lá. Um grupo de meninas rivais formou então o Bonde das Bad Girls para provocá-las. O duelo de rimas no palco do Coroado ganhou fama dentro e fora da Cidade de Deus, influenciando a formação de outros bondes e atraindo os brigões do Country (Apud MEDEIROS, Janaína, op. cit. p. 76-78).

${ }^{213}$ ESSINGER, Silvio, op. cit. p. 100, 108, 110, 147, 154; CARRANO, Paulo César Rodrigues, op. cit. p. 68. Não é tão recorrente quanto apregoam os organizadores, contudo, muitos MCs iniciaram suas carreiras a partir de raps apresentados em concursos e que depois "estouraram" nas rádios (HERSCHMANN, Micael, op. cit. p. 151). O DJ Marlboro lembra que o futebol é o motivo pelo qual a galera vai ao Maracanã e não tem culpa se, eventualmente, há assalto, briga ou tiroteio fora do estádio. Da mesma forma, o funk não pode ser responsabilizado pela violência, podendo até minimizá-la. Muitas músicas pregam a paz, pois, instintivamente, o funk quer tirar de si a culpa que insistem em lhe colocar (SALLES, Lúcia, op. cit. p. 44).

${ }^{214}$ ESSINGER, Silvio, op. cit. p. 118; SALLES, Lúcia, op. cit. p. 43.

215 Cf. CECCHETTO, Fátima, op. cit. p. 104, 112-114; HERSCHMANN, Micael, op. cit. p. 177. Esse fenômeno talvez ocorra porque não existe uma racionalidade linear entre o que esses jovens consideram violência e suas propostas para controle e superação da violência, embora, em muitos casos, a coerência exista (MINAYO, Maria Cecília de Souza et alii, op. cit. p. 184). 
principalmente em um mundo em que a definição da realidade assume um papel maior que a própria realidade e em que ambas se interpenetram o tempo todo. Segundo Mannheim,

\begin{abstract}
há filmes que abordam a questão da violência como se a sociedade fosse muito mais violenta do que realmente é; os reais fatores psicológicos e sociológicos da criminalidade são frequentemente distorcidos ou inteiramente ignorados em favor de um sensacionalismo barato; o delinquente é sempre pintado de forma demasiado atraente e como um herói; os órgãos de prevenção da criminalidade, em suas diversas instâncias, são mostrados como fracos, estúpidos ou brutais; o final do filme é frequentemente- se bem que talvez com menos frequência do que na vida real-demasiado favorável para com o criminoso, como se o crime compensasse. Enfim, a imagem idealizada do criminoso acaba por suscitar um envolvimento apaixonado com tal imagem, o que faz com que alguns possam querer referenciar-se com base nessa imagem, em face desse aprendizado. ${ }^{216}$
\end{abstract}

Apesar da dificuldade em se reconhecerem influenciáveis, os jovens de todos os estratos consideram que os filmes violentos exibidos na televisão todos os dias, em diversos horários, sem nenhum respeito às faixas etárias, e os jornais que se dedicam a exibir os crimes cotidianos influenciam crianças e os que têm "cabeça fraca", aumentando os conflitos da sociedade, na medida em que os veiculam de forma exagerada, incentivam e banalizam comportamentos violentos. O real funde-se à ficção, de maneira que uma guerra no Golfo Pérsico é confundida com uma guerra simulada no videogame. Jovens comentam que as lutas marciais constituem uma filosofia de vida, mas a televisão só coloca os aspectos do corpo e da força física. ${ }^{217}$

Apesar de as facções criminosas até reprimirem as brigas, as galeras glamorizam e se inspiram em filmes norte-americanos que mostram brigas de gangues de rua. ${ }^{218}$ Por

\footnotetext{
${ }^{216}$ Apud SHECAIRA, Sérgio Salomão. Criminologia. São Paulo: Revista dos Tribunais, 2004. p. 203 et seq. Ainda nos anos 30 estabeleceu-se a hipótese de que o impacto da imagem cinematográfica, exibindo cenas medonhas e personagens movidos pelo desejo de dinheiro fácil e sexo alterava padrões de comportamento das pessoas, especialmente das crianças. Para Edgar Morin, "o espetáculo da violência ao mesmo tempo incita e apazigua". No Ocidente, muitos estudos que buscam relacionar filmes e desajustamentos juvenis "esqueceram-se por completo de que para o herói real da acumulação capitalista o dinheiro é algo fácil, e que o sexo é um dos mais recorrentes motivos na propaganda de seus produtos. Pedrinho Guareschi lembra que a fetichização dos meios de comunicação permite à classe dominante falar da 'influência perniciosa e desagregadora' ou do 'conteúdo vulgar, violento ou pornográfico' dos programas editados por seus próprios veículos" (Apud BATISTA, Nilo. Punidos e mal pagos: violência, justiça, segurança pública e direitos humanos no Brasil de hoje. Rio de Janeiro: Revan, 1990. p. 135).

${ }^{217}$ Há opiniões contrárias, todavia, no sentido de que a televisão é um instrumento neutro, à espera das interpretações de quem assiste a ela. Vários estudos sobre a violência na televisão apontam para uma tendência natural da criança para a imitação, o que é dado como causa de mortes ou acidentes de crianças por tentarem imitar os heróis da televisão em suas lutas (MINAYO, Maria Cecília de Souza et alii, op. cit. p. 139 et seq).

${ }^{218}$ GUIMARÃES, Eloísa, op. cit. p. 106. Robocop, Schwarzenegger, Van Dame, entre outros, são as referências no cultivo do corpo e dos movimentos dos membros das galeras (CUNHA, Olívia M. G. "Bonde do mal". In: MAGGIE, Yvonne; REZENDE, Cláudia B. (Org). Raça como retórica: a construção da diferença. Rio de Janeiro: Civilização Brasileira, 2001. p. 133).
} 
outro lado, da mesma forma como a televisão influencia o estilo e a imagem do funkeiro, a proximidade e a convivência com traficantes seduzem e contaminam sua linguagem/código de conduta, fazendo com que incorporem muitas vezes em suas autorrepresentações os adjetivos estigmatizantes veiculados nos jornais. Os membros das galeras inimigas são chamados de "alemães", assim como os membros das quadrilhas inimigas. Se por um lado, a associação simbólica de uma galera com o tráfico contribui decisivamente para a sua criminalização, por outro lado a torna mais perigosa, "sinistra", poderosa sob o enfoque desta subcultura e, portanto, mais respeitada. ${ }^{219}$

Muitos rapazes que frequentam os bailes se queixam de que, por serem negros, jovens, pobres e gostarem de funk, são alvos de preconceito, considerados automaticamente suspeitos, revistados com frequência por policiais e barrados em casas noturnas, shoppings e ônibus. Preocupados em desfazer a imagem violenta do funkeiro, afirmam que a violência é uma experiência eventual no funk, da qual todos querem escapar, e enumeram uma série de outros assuntos pelos quais se interessam. Por outro lado, nas falas desses mesmos rapazes pode-se notar a grande relevância que a violência tem em suas vidas. Não escondem o prazer de ir para o baile "encher a galera inimiga de porrada" e defendem a legitimidade da guerra, afinal violentas são as galeras “alemãs".

Ao mesmo tempo em que tenta romper com o estigma de ser "favelado", o funkeiro reincorpora o estigma marginal no uso de palavras cujo duplo sentido sugere simultaneamente violência, força, união, perigo, beleza e honra, tais como "sinistro", "do mal", "abalar", "terror" etc. Ir a bailes famosos por serem "bailes de briga" demonstra "ter disposição", coragem, força, e faz a fama e a honra de uma galera. ${ }^{220}$ A morte de inimigos e companheiros muitas vezes é narrada pelas galeras de forma exagerada, excitadamente. O objetivo é, de modo geral, impressionar os ouvintes, valorizando-se perante o grupo. Um dos lideres de galera afirma que brigam porque é legal, é gostoso, mas também para que respeitem a galera, "tenham medo, não mexam com o pessoal". 221

\footnotetext{
${ }^{219}$ Cria-se, desta maneira, uma relação territorial e política do mesmo tipo da que é estabelecida entre as galeras e suas comunidades e bairros de origem (CUNHA, Olívia M. G. "Bonde do mal". In: MAGGIE, Yvonne; REZENDE, Cláudia B. (Org). Raça como retórica: a construção da diferença. Rio de Janeiro: Civilização Brasileira, 2001. p. 135).

${ }^{220}$ CUNHA, Olívia M. G. "Bonde do mal". In: MAGGIE, Yvonne; REZENDE, Cláudia B. (Org). Raça como retórica: a construção da diferença. Rio de Janeiro: Civilização Brasileira, 2001. p. 118-119, 124-125, 137-139; Id. Conversando com Ice-T: violência e criminalização do funk. In: HERSCHMANN, Micael (Org.). Abalando os anos 90: funk e hip-hop - globalização, violência e estilo cultural. Rio de Janeiro: Rocco, 1997. p. 103-104.

${ }^{221}$ HERSCHMANN, Micael, op. cit. p. 175.
} 
Dançarinos contavam a pesquisadores histórias excessivas sobre brigas, tiros e assassinatos para convencê-los de que os bailes eram realmente lugares muito perigosos, talvez para protegê-los, talvez para serem "sinceros", talvez para assustar, talvez para afastar os estranhos dos melhores bailes (justamente aqueles que eram considerados mais perigosos), talvez porque a imagem violenta seja atraente para determinados tipos de subculturas urbanas. Talvez os funkeiros, "valentões" só por performance, não esperassem que os outros grupos sociais fossem acreditar, divulgar essa imagem e usá-la contra seu principal divertimento. A imagem ameaçadora acabou colando, talvez porque havia a tendência de que colasse, havia a expectativa social de que aquelas histórias horripilantes fossem verdadeiras. O feitiço se voltou contra o feiticeiro e, para tentar desfazê-lo, muitas letras de funk tentam provar para o mundo que o baile não é ou não deve ser violento. ${ }^{22}$

A teoria da rotulação social ou labelling approach chamou a atenção para a delinquência secundária, aquela que resulta do processo causal desencadeado pela estigmatização. De acordo com o princípio da profecia autorrealizadora (self-fullfilling profecy), a expectativa do ambiente circunstante determina, em grande medida, o comportamento do indivíduo. A vítima do estigma passa a se comportar do modo como os outros esperam que ela se comporte. ${ }^{223} \mathrm{Na}$ medida em que "funkeiro" foi o termo eleito pela mídia e setores conservadores da sociedade para designar estes jovens ameaçadores, com uma conotação claramente pejorativa, a identidade foi assumida com orgulho, já que é própria das subculturas delinquentes a polaridade negativa de suas ações, ou seja, assumir os valores da sociedade, mas com o sinal invertido, de maneira que o que é visto como repulsivo pela sociedade passa a ser motivo de status para o membro da subcultura.

A estigmatização faz com que o jovem, até como mecanismo de defesa psíquico, acabe se definindo como os outros o definem, altere sua identidade social, identifique-se com o estigma que lhe é imposto, interaja com ele, assuma o papel de desviante (role engulfment). ${ }^{224}$ Este processo contribui para a aproximação do jovem estigmatizado com iguais, pessoas que sofrem o mesmo estigma, têm o mesmo comportamento desviante e, em um segundo momento, para a construção de uma carreira criminal. A internalização da

\footnotetext{
${ }^{222}$ VIANNA, Hermano, $O$ mundo funk carioca. 2 ed. Rio de Janeiro: Zahar, 1988. p. 88; Id. "O funk como símbolo da violência carioca”. In: VELHO, Gilberto; ALVITO, Marcos. Cidadania e violência. Rio de Janeiro: UFRJ/FGV, 1996. p. 186-187.

${ }^{223}$ BARATTA, Alessandro. Criminologia crítica e crítica do Direito Penal: introdução à sociologia do direito penal. Rio de Janeiro: Revan, 1997. p. 174.

${ }^{224}$ SHECAIRA, Sérgio Salomão. Criminologia. São Paulo: Revista dos Tribunais, 2004. p. 298.
} 
rotulação pelos membros das subculturas fica explícita em suas tatuagens e na forma como exibem, orgulhosos, cicatrizes oriundas de brigas.

Na perspectiva das gangues, as marcas de um corpo "iniciado" contam sua história, “condensam registros mudos de identidade", funcionam como códigos de inserção etc. ${ }^{225}$ Os jovens não temem os danos físicos que sofrem ou provocam, seja porque estes podem ser usados como uma espécie de medalha, uma demonstração do "ethos da virilidade", da disposição para brigar, da capacidade de se firmar como "homem", seja pela crença na sua invencibilidade frente à morte, seja pelo gostinho em correr riscos. ${ }^{226}$

O comportamento das galeras, apesar de ser secularizado, lembra de certa maneira a atuação das "sociedades de guerreiros", para as quais coragem, honra, virilidade e vingança são importantes valores e nas quais a violência tem um alcance limitado. ${ }^{227}$ Uma reportagem da revista inglesa Mixmag, de 2001, definiu os bailes de corredor como uma mistura de rave e Clube da Luta, onde "você luta por sua vida". Os garotos apontam que, além da "defesa do território", as brigas são motivadas pela admiração feminina, já que "é mais fácil arrumar garotas sendo valente". 228

O fato de um funkeiro ser bonito, vestir-se bem e ser bom dançarino é valorizado pelos frequentadores dos bailes, mas o fato de ele ser corajoso, forte e "ter disposição" pode ser determinante na sua inclusão ou no papel que desempenha no grupo. ${ }^{229}$ Os melhores "guerreiros" têm a tendência de emergir como líderes e fazem muito sucesso entre as mulheres, razão pela qual os bailes atraem lutadores de jiu-jítsu de classe média e alguns frequentadores dos bailes procuram ser confundidos com eles, adotando seu visual. $^{230}$

\footnotetext{
${ }^{225}$ As galeras, no geral, carregam apenas uma tatuagem de localização mais discreta e os corpos não carregam em si as marcas das experiências cotidianas da violência (DIÓGENES, Glória. "Gangues e polícia: campos de enfrentamento e estratégias de diferenciação". In: PEREIRA, Carlos Alberto Messeder; RONDELLI, Elizabeth; SCHOLLHAMMER, Karl Erik; HERSCHMANN, Micael (Org.). Linguagens da violência. Rio de Janeiro: Rocco, 2000. p. 200).

${ }^{226}$ CECCHETTO, Fátima, op. cit. p. 97, 108.

${ }^{227}$ HERSCHMANN, Micael, op. cit. p. 174-175. As brigas entre galeras são descritas às vezes como uma microguerra, análoga à guerra do tráfico. Outras vezes, a disputa é setorizada, relacionada a certas galeras, a certos "alemães", a certos bailes, pontos e lugares (CUNHA, Olívia M. G., op. cit. p. 137-138). Verifica-se um complexo padrão interativo entre organizadores, DJs, MCs e frequentadores, que envolve a negociação e a aceitação tácita de códigos de violência relativamente associados à lógica agônica da guerra, recriada e atualizada no âmbito do lazer e da sociabilidade juvenil (CECCHETTO, Fátima, op. cit. p. 98).

${ }_{228} \mathrm{O}$ texto da Mixmag cita uma conta de mil mortes provocadas pelo baile de corredor. A situação calamitosa nos bailes teria colaborado para a redução do número de equipes de som de $400 \mathrm{em} 1995$ para apenas $100 \mathrm{em}$ 2001 (ESSINGER, Silvio, op. cit. p. 206-207).

${ }^{229}$ HERSCHMANN, Micael, op. cit. p. 178.

${ }^{230}$ CECCHETTO, Fátima, op. cit. p. 108; HERSCHMANN, Micael, op. cit. p. 143, 180, 276. Reportagens da época dos bailes de corredor diziam que os traficantes estavam aproveitando as batalhas do funk para recrutar
} 
Alguns jovens de classe média que praticam o jiu-jítsu o concebem como uma atividade do mais alto valor pelo seu caráter de disciplina e de competição esportiva e mostram preocupação com algumas escolas que sobrevalorizam as expressões de força. Outros praticantes do esporte, porém, se envolvem em episódios de violência em festas e criam grupos nos locais de moradia que costumam, por meio da luta corporal, defender as garotas das "cantadas" indesejadas de rapazes de outros grupos ou solucionar conflitos que venham a surgir no contexto das diversões. Na pesquisa domiciliar realizada por Minayo et alii, $16,6 \%$ dos jovens de classe média e 7,8\% dos jovens de classes populares disseram que estão inseridos em grupos de artes marciais, mostrando ser esse esporte mais difundido entre os primeiros. Dentre esses jovens que lutam, um em cada dez admite brigar com outros grupos. Já entre os rapazes e moças que não praticam lutas, apenas um em cada vinte assim admitiu. ${ }^{231}$

Se o ambiente produzido pelo funk é nitidamente masculino, a presença feminina é fundamental para descontrair o baile, criando um clima de sedução que rivaliza e se articula com o de competição. ${ }^{232}$ Uma área superior de um ginásio onde se realizava baile de corredor só podia ser acessada por mulheres, não só para evitar o conflito em uma área perigosa, de onde uma queda poderia ser fatal, mas também para que elas, que não participavam do "corredor", tivessem a regalia de acompanhar dali as performances de seus "guerreiros" e flertar com algum deles.

As meninas, algumas aparentando ser de classe média, usam todas as armas para atrair a atenção dos rapazes. Vários "guerreiros" lutam sem camisa, pois gostam de exibir seu corpo. Em geral, a garota que fica com a camisa do "guerreiro" durante os embates, e a quem ele confia algum objeto seu que não deseja rasgar ou perder durante o jogo, possui mais status e é conhecida como "garota-cabide". Ela aguarda o "guerreiro" e é recompensada, quando ele chega, com carícias e beijos. ${ }^{233}$

os guerreiros mais capazes e que esses bailes estavam dando lugar a um grande jogo chamado Mortal Kombat, do qual participavam também lutadores de artes marciais e frequentadores de academias da Zona Sul e Barra (ESSINGER, Silvio, op. cit. p. 191-192).

${ }^{231}$ MINAYO, Maria Cecília de Souza et alii, op. cit. p. 52-54. Shecaira cita como exemplo de subcultura de classe média, hedonista e irresponsável, as gangues de jiu-jítsu, que saem pela noite da Zona Sul carioca desafiando pessoas em lutas que não têm qualquer justificativa racional, ao menos pelas outras teorias explicativas da criminalidade. O único prazer desses jovens, cujas tensões pessoais e familiares são projetadas para atos delinquenciais, é provocar pessoas para afirmar a aparente masculinidade resultante da prática de atos marciais (SHECAIRA, Sérgio Salomão. Criminologia. São Paulo: Revista dos Tribunais, 2004. p. 263-264).

${ }^{232}$ HERSCHMANN, Micael, op. cit. p. 158.

${ }^{233}$ Ibid, p. 138-139; CARRANO, Paulo César Rodrigues, op. cit. p. 67. 
A disputa por mulheres motiva algumas brigas e elas participam desse jogo, que tende a reafirmar o machismo e a submissão. ${ }^{234} \mathrm{Um}$ fator desencadeador de brigas é justamente o comportamento das namoradas dos "bandidinhos" que "gostam de arrumar confusão". As provocações podem derivar de um olhar que se dê na direção delas, de um esbarrão, ou acontecer de modo totalmente gratuito. Têm como objetivo envolver o namorado em sua defesa, mostrando que "por ser namorada de bandido, ela pode tudo, ela tem poder". 235

A ética das relações entre os gêneros no interior do baile funk confere o direito do rapaz punir com violência sua namorada quando dá mole para outro jovem, ainda mais de uma galera rival. A tentativa de abandono por parte da mulher resulta sempre em espancamentos ou morte. O envolvimento com o "bandidinho", mesmo quando involuntário, ainda insere a garota nas guerras entre grupos e galeras, trazendo potencialmente a ameaça de morte, pois quando um "vagabundo" quer matar o outro e não o encontra, pode pegar ou matar a namorada, para servir de isca. ${ }^{236}$

$\mathrm{O}$ fato de a violência física aparecer ligada a uma imagem masculinizada do funk não quer dizer que esteja totalmente ausente do universo das mulheres. Quase sempre as lutas corporais acontecem entre dois homens ou entre duas mulheres. Frequentadoras de baile funk relatam que, quando ocorrem, as brigas entre as meninas geralmente são batebocas, se dão fora do baile, "por causa de homem", e não estão relacionadas a "briga de funk". O que parece estar em questão não é, portanto, uma masculinização do discurso da violência, mas uma representação masculinizada do funk, em que a violência aparece como uma das formas mais marcadas de expressão. ${ }^{237}$

\footnotetext{
${ }^{234}$ Um jovem chega a afirmar que "se tivesse um filé (uma garota bonita) para cada um, não ia sair briga" (MINAYO, Maria Cecília de Souza et alii, op. cit. p. 58). Deve-se questionar, todavia, até que ponto a disputa por mulheres não é um pretexto para se envolver em brigas, o objetivo maior. Afinal, é próprio da subcultura o negativismo das condutas, ou seja, o prazer em infligir dor ou incômodo na vítima, no caso, o namorado da garota assediada.

${ }^{235}$ Em muitos casos os "bandidinhos" contribuem para evitar as confusões, quando reconhecem em quem é provocado um elemento de sua própria área ou alguma amiga de infância ou investigam a procedência da "denúncia", repreendendo a namorada e comunicando à pessoa provocada que está "tudo limpo" (GUIMARÃES, Eloísa, op. cit. p. 186-187).

${ }^{236}$ GUIMARÃES, Eloísa, op. cit. p. 191-192; CARRANO, Paulo César Rodrigues, op. cit. p. 68-69. Algumas vezes, as moças que integram as galeras, aparentemente ausentes dos confrontos, atuam estrategicamente como uma espécie de "isca" ou "estopim" de um embate entre duas galeras (HERSCHMANN, Micael, op. cit. p. 160).

${ }^{237}$ CUNHA, Olívia M. G. "Conversando com Ice-T: violência e criminalização do funk". In: HERSCHMANN, Micael (Org.). Abalando os anos 90: funk e hip-hop - globalização, violência e estilo cultural. Rio de Janeiro: Rocco, 1997. p. 100; Id. "Bonde do mal". In: MAGGIE, Yvonne; REZENDE, Cláudia B. (Org). Raça como retórica: a construção da diferença. Rio de Janeiro: Civilização Brasileira, 2001. p. 119-120; MINAYO, Maria Cecília de Souza et alii, op. cit. p. 58; VIANNA, Hermano, op. cit. p. 77.
} 


\subsection{O fechamento dos bailes}

A violência nos bailes e a reclamação de moradores vizinhos aos clubes em relação às brigas e depredações constantes nas saídas desses eventos facilitaram a campanha de estigmatização do funk por parte da mídia e pressionaram as autoridades policiais a fechar os bailes. A repressão aos bailes funk, todavia, apresentou efeitos contraproducentes. Não se pode generalizar e afirmar que todos os frequentadores dos bailes funk no Rio de Janeiro fazem parte das galeras que se confrontam nos bailes ou lugares públicos. Vários jovens, por limitação financeira, têm sua opção de lazer restrita ao funk e acionam outros mecanismos para se afastarem das brigas, quase sempre interpretadas como possibilidade de abertura para a relação com o pessoal do tráfico e/ou das galeras. Evitam, por exemplo, os lugares demarcados por cada galera, as áreas de confusão nos clubes, relações com determinados grupos e/ou indivíduos, esbarrar na namorada dos outros e ser abordado pelo "bandidinho" etc. 238

Segundo o DJ Marlboro, surgem problemas nos bailes funk como em todos os lugares onde se lida com tanta gente. Cabe ao Poder Público dar segurança para os frequentadores dos bailes se divertirem em paz, identificar os bailes problemáticos e punir apenas os responsáveis. A polícia e as autoridades, entretanto, confundiram as vítimas com o problema, generalizaram e fecharam mesmo os bailes que não tinham corredor, prejudicando inclusive organizadores, MCs e DJs que combatiam os bailes de corredor. Os bailes legais enfraqueceram-se ou acabaram, pois as diretorias dos clubes, em razão da generalização da mídia, se sentiram pressionadas a barrá-los de sua programação.

A cada vez que a mídia anunciava o fechamento dos bailes, os organizadores, com medo, suspendiam a realização de bailes, para, aos poucos, os mais corajosos irem voltando normalmente. Foram beneficiados os organizadores que pagavam propina a policiais, que se aproveitavam da ameaça de fechamento do baile antecipada pela mídia. A arbitrariedade policial não diminuiu com a edição de leis repressoras, que exigiam prévia autorização do batalhão para a realização dos bailes. ${ }^{239}$ Além disso, a atribuição do

\footnotetext{
${ }^{238}$ GUIMARÃES, Eloísa, op. cit. p. 151, 157; CECCHETTO, Fátima, op. cit. p. 96-97.

${ }^{239}$ ESSINGER, Silvio, op. cit. p. 192; SALLES, Lúcia, op. cit. p. 43; MACEDO, Suzana, op. cit. p. 109. No campo da violência nos estádios, há a tentação das generalizações fáceis, que implicam em acabar com as torcidas, em razão "das uniformizadas terem se desviado de suas finalidades originais". "A Escola e a Saúde públicas, a Justiça, os parlamentos... por vezes (várias) não têm se desviado de suas metas de origem? E o que fazer: eliminar ou transformar? As torcidas organizadas são instituições comunitárias importantes para a
} 
comportamento violento de uma minoria a uma maioria pacífica aumentou sua vulnerabilidade e fez com que esta começasse a se identificar com o estigma, agravando a violência. $^{240}$

No Rio de Janeiro, as brigas em discotecas que tocavam house eram atribuídas aos "de fora", pirralhos ou "bandidinhos" infiltrados, e o preço do ingresso era aumentado quando os bailes funk estavam proibidos para afastar essa "clientela". No entanto, eram exatamente alguns dos "bandidinhos" que dispunham dos recursos para adquirir o ingresso, levando parte dos frequentadores do house a se transferir para outros clubes ou a desistir de frequentá-los nesses períodos. ${ }^{241}$

As medidas de prevenção situacional da criminalidade não combatem suas causas primárias, mas buscam impedi-las de se manifestar em determinados contextos, incrementando o esforço ou dificuldade da prática do delito na percepção individual do infrator. Uma dessas medidas reside justamente em neutralizar os mecanismos de desinibição, como a violência televisiva e o álcool, que outorgam ao indivíduo técnicas de justificação e álibis para comportamentos delitivos. As letras pedindo paz no funk e o estabelecimento de prêmios e recompensas simbólicas nos concursos de galeras são exemplos de campanhas de sensibilização, que incrementam os sentimentos de culpabilidade do infrator e reforçam positivamente o comportamento conforme às normas de conduta.

Outras medidas de prevenção situacional buscam inutilizar certos espaços físicos, como os bailes, ou limitar temporalmente o uso de outros, como bares, para mitigar a

cultura da massa (...) no Brasil e para a afirmação de uma coletividade (...). Se há desvios - e há - cumpra-se a lei, exerça-se a autoridade pública e o controle social sobre os torcedores uniformizados. Identificação e punição, sem generalização - este o método eficaz de combate à impunidade e triunfo da cidadania. O que falta é vontade política, porque em verdade o problema já está diagnosticado e é bem menor do que se supõe (...). As torcidas organizadas são parcela pequena no universo de milhões de torcedores (...). E dentro das organizadas, os violentos, brigões ou arruaceiros, numa palavra, vândalos (prazer sádico com a violência) formam um segmento ainda menor, ou seja, em torno de 5\%" (MURAD, Maurício, op. cit. p. 116).

${ }^{240}$ ARCE, José Manuel Valenzuela, op. cit. p. 96; MEDEIROS, Janaína, op. cit. p. 57-58.

${ }^{241}$ GUIMARÃES, Eloísa, op. cit. p. 155. Na época da pesquisa de campo de Vianna, quando havia muita briga, alguns clubes aumentavam a entrada, numa tentativa de "selecionar" quem teria acesso ao baile (VIANNA, Hermano, op. cit. p. 40). No bairro da Vila Olímpia, em São Paulo, os donos das baladas utilizam diversos artifícios para manter jovens pobres do lado de fora, como preços abusivos, exigência de determinado tipo de vestimenta para ingressar na casa e listas VIPs de pessoas "bem selecionadas" (BORGES, Ana Luiza Mendes; AZEVEDO, Clara de Assunção. "A mancha de lazer na Vila Olímpia”. In: MAGNANI, José Guilherme Cantor; MANTESE, Bruna (Org.). Jovens na Metrópole: etnografias de lazer, encontro e sociabilidade. São Paulo: Editora Terceiro Nome, 2007. p. 100-101). A presença desses jovens, estigmatizados como "baianos", é considerada contaminadora, rebaixa o status social da balada e faz com que ela deixe de ser considerada pelo público que interessa, os "bem selecionados", como um lugar da moda (Ibid. p. 100, 115). 
possível convergência em tempo e espaço de infratores tentados a cometer o delito. ${ }^{242}$ Uma prevenção orientada a critérios rigorosamente espaciais, porém, obstaculiza, adia ou desloca a prática do delito, mas não o evita. O crime ocorrerá em outro espaço físico menos protegido, geralmente áreas e espaços cujos titulares não possam financiar o custo dos dispositivos de proteção. ${ }^{243}$

Simplesmente fechar bailes significa aumentar as possibilidades de confronto entre galeras rivais, na redistribuição dos "órfãos" por outros pontos de baile. Com o fechamento do baile do Boêmios do Irajá em 1993, por exemplo, as galeras brigonas migraram para os bailes do Mesquitão, Coleginho, Pavunense e Praça Seca. Já a venda do ginásio de natação do Botafogo, com o consequente fechamento do baile do Mourisco, redundou na migração da "Torcida Jovem-Bota" para o baile do Clube Carioca, no Jardim Botânico, reduto da "Jovem-Flá", sua tradicional inimiga do Maracanã, e em conflitos que resultaram até em morte. $^{244}$

Com a leitura do livro "A cidade de quartzo", de Mike Davis, Manoel Ribeiro chegou à conclusão de que não se devia repetir no Rio a política de confinamento adotada em Los Angeles, porque, ao contrário do pretendido, acabou tornando as gangues confinadas mais organizadas, mais violentas e federalizadas sob a orientação de duas grandes facções, os Bloods e os Crips, que passaram a controlar o comércio de crack na cidade. $^{245}$

Com o crescimento das cidades, os hábitos humanos passam a guardar certas características por áreas. A mobilidade das camadas baixas da população, tão combatida, conforme visto no capítulo anterior, tenderia a solapar a permanência e a intimidade da

\footnotetext{
${ }^{242}$ GOMES, Luiz Flávio; GARCÍA-PABLOS DE MOLINA, Antonio. Criminologia: introdução a seus fundamentos teóricos: introdução às bases criminológicas da Lei 9.099/95, lei dos Juizados Especiais Criminais. 7 ed. São Paulo: RT, 2010. p. 356-357. Campanhas que movimentam milhares de funkeiros pra doação de sangue, todavia, não costumam interessar tanto a mídia quanto quando o sangue é desperdiçado nos bailes (SALLES, Lúcia, op. cit. p. 47).

${ }^{243}$ Por sua vez, "os poderes públicos polarizarão os esforços preventivos, entendidos em uma acepção meramente policial, em torno dos subgrupos definidos ex ante como populações "conflituosas", sempre minorias e baixos estratos sociais. As técnicas e estratégias da prevenção situacional "são muito invasivas, afetam terceiros alheios à gênese do risco ou perigo, possuem uma imanente tendência expansiva propensa a toda sorte de excessos e são infensos a controle e limites externos" (GOMES, Luiz Flávio; GARCÍAPABLOS DE MOLINA, Antonio, op. cit. p. 360-361).

${ }^{244}$ Após desentendimentos no baile, um jovem de classe média, morador do Leme e torcedor do Botafogo, perseguiu em seu carro o ônibus que levava o pessoal da "Jovem-Flá" e atirou com uma pistola automática, matando um garoto de 15 anos (RIBEIRO, Manoel, op. cit. p. 289). Um dos membros de galera declarou que "se a gente não pode ir ao baile aqui na comunidade, porque a polícia proibiu, a gente se reúne e vai para um coleginho, vai para o Irajá, e vai para outros bailes que são muito mais conflituosos" (DEBATE 7 Organizações comunitárias, cultura popular e violência II. In: ALVITO, Marcos; VELHO, Gilberto. Cidadania e Violência. Rio de Janeiro: UFRJ e FGV, 1996. p. 357).

${ }^{245}$ Apud VENTURA, Zuenir, op. cit. p. 98-99.
} 
vizinhança. $\mathrm{O}$ isolamento dessas pessoas, contudo, cria uma região moral, onde indivíduos da mesma classe social, origem, cor ou etnia passam a intensificar a intimidade e os laços de vizinhança e solidariedade. Daí porque a noção de "comunidade" é tão importante para esses jovens.

A região moral não é necessariamente um local de residência, mas também um local de diversão, zona, "distritos de depravação". Muitas vezes uma região moral surge em face da segregação do pobre, do viciado, do excêntrico, do desajustado ou do criminoso. Na cidade grande a pessoa busca se associar com pessoas que possuem identidades comuns, como forma de proteção, suporte moral e reforço de sua postura individual. ${ }^{246}$ De acordo com as leis de imitação de Gabriel Tarde, os valores dominantes no seio do grupo "ensinam" o delito. Uma pessoa converte-se em delinquente quando as definições favoráveis à violação superam as desfavoráveis, a imitação decorre do grau de intimidade dos contatos interpessoais e o aprendizado inclui a própria racionalização (justificação) da conduta delitiva. ${ }^{247}$

Os primeiros bailes black eram realizados no Canecão, casa de shows na Zona Sul carioca, e frequentados por um público bastante heterogêneo. Com a elitização do Canecão, os bailes se transferiram para clubes do subúrbio e passaram a ser frequentados por um público predominantemente negro e pobre. A decisão de livrar a Zona Sul das galeras não levou em conta que o confinamento de jovens em suas comunidades potencializa determinados comportamentos nascidos naqueles locais e sob aquelas condições de vida. ${ }^{248}$

A segregação imposta aos morros cariocas fez com que emergissem relações de mando e de proteção instaurados pelos "donos dos morros”, que não foram produzidas, mas incorporadas e exacerbadas pelas galeras. ${ }^{249} \mathrm{O}$ fato de a área de origem dos funkeiros estar sob o domínio de uma organização criminosa provoca movimentos de identificação, sem que isso demonstre a vinculação das galeras a ela. Na visão de Rômulo Costa, por "representar" a área, a organização recebe sinal positivo e seus signos são incorporados como elementos de disputa entre as equipes, o que esclareceria, inclusive, os sinais dos comandos exibidos pelos grupos de funk e pelas galeras em suas aparições públicas. ${ }^{250}$

\footnotetext{
${ }^{246}$ SHECAIRA, Sérgio Salomão. "Importância e atualidade da Escola de Chicago". In: Discursos Sediciosos: crime, direito e sociedade, v. 9/10. Rio de Janeiro: Freitas Bastos, 2000. p. 155-156.

${ }^{247}$ Apud SHECAIRA, Sérgio Salomão. Criminologia. São Paulo: Revista dos Tribunais, 2004. p. 194 et seq.

${ }^{248}$ RIBEIRO, Manoel, op. cit. p. 289.

${ }^{249}$ GUIMARÃES, Eloísa, op. cit. p. 94 et seq.

${ }^{250}$ Ibid,. p. 181-183.
} 
Segundo um dos coordenadores do Projeto Rio Funk, seu principal objetivo foi dispersar a presença maciça e conflituosa de galeras rivais em bailes de clube, interromper sua "periculosidade" e o poder do tráfico. Para isso, dotaram os bailes de comunidade de recursos, estimulando sua produção, pelos próprios funkeiros, em contato direto com as equipes. ${ }^{251}$

A proibição de bailes de clube no Rio de Janeiro favoreceu a migração das galeras e o fortalecimento dos chamados bailes de comunidade. Com a perseguição, o funk saiu dos clubes, onde as autoridades poderiam fiscalizá-lo, e foi acolhido dentro das comunidades, onde "começa a ter a cara da realidade das pessoas que vivem lá", a "retratar o cotidiano, personagens e fatos específicos deste espaço urbano" e a "se sujeitar às autoridades locais". ${ }^{252} \mathrm{O}$ palco dos bailes, um espaço de destaque, acabaria sendo usado por pessoas com prestígio na favela, cantores que celebravam a possibilidade de fazer a festa, apesar da linha dura imposta pela lei. ${ }^{253}$ A profecia negativa contribui para a sua própria realização e a ação policial só contribuiu para empurrar a população para a área de influência da liderança marginal. ${ }^{254}$

${ }^{251}$ CUNHA, Olívia M. G., op. cit. p. 149.

${ }^{252}$ MACEDO, Suzana, op. cit. p. 42; ESSINGER, Silvio, op. cit. p. 235; RUSSANO, Rodrigo. "Bota o fuzil pra cantar": o funk proibido no Rio de Janeiro. 2006. 124 f. Dissertação (Mestrado) - Centro de Letras e Artes, Programa de Pós-Graduação em Música, UNIRIO, Rio de Janeiro, 2006. p. 8; GUEDES, Maurício da Silva. A música que toca é nós que manda: um estudo do proibidão. 2007. Dissertação (Mestrado) Departamento de Psicologia, Pontifícia Universidade Católica, Rio de Janeiro, 2007. p. 68. A proibição dos bailes de comunidade pela Lei Pitanga, por outro lado, empurrou os bailes para territórios "neutros", onde as brigas eram permitidas (MEDEIROS, Janaína, op. cit. p. 56).

${ }^{253}$ RUSSANO, Rodrigo, op. cit. p. 14.

${ }^{254}$ VENTURA, Zuenir, op. cit. p. 142-143. Hermano Vianna corrobora esta tese: "Políticos, polícia e a mídia têm grande parcela de culpa na aproximação entre o funk e o tráfico. Se o poder público tivesse percebido a força cultural do funk, tornando possível que suas festas se desenvolvessem de maneira legal na cidade, em vez de burramente proibi-las, muito provavelmente os proibidões não existiriam. Na minha opinião, não há outro caminho: o movimento funk precisa se organizar para descriminalizar os bailes, que continuam a ser tratados como atividades criminosas. $\mathrm{O}$ funk deixaria de ser um caso de polícia para se tornar um elemento decisivo na instauração da paz na cidade" (Apud MEDEIROS, Janaína, op. cit. p. 105). 


\section{OS BAILES DE COMUNIDADE E O "PROIBIDÃO"}

\subsection{O financiamento e a segurança dos bailes de comunidade.}

Os bailes de comunidade, realizados em quadras, clubes e terrenos dentro das favelas ou bairros populares, também são conhecidos como "bailes do bicho" ou "bailes do contexto", termos que remetem ao tráfico. ${ }^{255}$ Por serem geralmente gratuitos, pelo menos para as mulheres, ou terem seu preço bastante acessível, geraram-se suspeitas de que são financiados pelo tráfico local. Empresários e DJs do mundo funk alegam que tais bailes são financiados pela própria comunidade, seja pelos barraqueiros interessados na venda de bebidas e comidas, seja pela associação de moradores, e dizem também que se há traficantes vendendo drogas, basta colocar policiamento nos bailes para coibi-los. ${ }^{256}$ Quando os donos de equipes de som e DJs são pressionados a esclarecer as acusações de que são pagos por traficantes interessados em criar um ambiente que estimule o consumo de drogas, respondem que não cabe a eles investigar se a origem desse dinheiro é lícita ou ilícita, mas sim à polícia.

Por ser uma das únicas alternativas de lazer da juventude pobre e favelada, é natural que as associações de moradores tenham interesse em ajudar na realização dos bailes de comunidade, ainda mais porque tais bailes constituem um espaço de sociabilidade importante e muitos MCs da comunidade só têm espaço para cantar suas músicas nesses palcos, elevando a auto-estima da comunidade como um todo. Entretanto, há denúncias de que muitas associações de moradores das comunidades do Rio de Janeiro foram cooptadas pelo tráfico e constituem o seu canal lícito de atuação.

Por trás das acusações de condescendência com o tráfico, pode haver simplesmente a necessidade de a associação dos moradores conviver e negociar com o traficante, um relevante ator político do morro. Os líderes comunitários são os mediadores mais

\footnotetext{
${ }^{255}$ VIANNA, Hermano. O mundo funk carioca. $2^{\text {a }}$.ed. Rio de Janeiro: Zahar, 1988. p. 83, 111; VENTURA, Zuenir. Cidade partida. Rio de Janeiro: Companhia das Letras, 1994. p. 61. O termo "comunidade" notabilizou-se especialmente com os movimentos eclesiais de base dos anos 70 e foi adotado para se contrapor ao estigma do termo "favela" e fortalecer o sentido comunitário do trabalho desenvolvido (HERSCHMANN, Micael. O funk e o hip hop invadem a cena. Rio de Janeiro: Editora UFRJ, 2000. p. 168169, 181). Cf. também CECCHETTO, Fátima; FARIAS, Patrícia. Do funk bandido ao pornofunk: o vaivém da sociabilidade juvenil carioca. In: Interseções: Revista de Estudos Interdisciplinares, ano 4, número 2. Rio de Janeiro: PPGCS/UERJ, 2002. p. 61; CUNHA, Olívia M. G. Conversando com Ice-T: violência e criminalização do funk. In: HERSCHMANN, Micael (Org.). Abalando os anos 90: funk e hip-hop globalização, violência e estilo cultural. Rio de Janeiro: Rocco, 1997. p. 106.

${ }^{256}$ ESSINGER, Silvio. Batidão: uma história do funk. Rio de Janeiro: Record, 2005. p. 243.
} 
importantes de diversas relações: com os moradores, com os políticos, com as autoridades, com o tráfico, com a imprensa, com ONGs. Para ser um mediador, certamente é preciso ter algum tipo de vínculo com todos os lados. ${ }^{257}$ Alguns presidentes de associações de moradores têm vínculos de amizade e/ou parentesco com traficantes e intermedeiam as relações entre o tráfico e a polícia, fazendo os "acertos".

O fato de a associação de moradores depender da palavra final do chefe do tráfico para realizar suas funções não indica necessariamente conivência ou uma aliança, mas simplesmente uma realidade que se impõe, independentemente da vontade da diretoria da associação. A política assistencialista adotada tradicionalmente pelos traficantes para se legitimarem perante a comunidade e efetuada muitas vezes em esforço comum com a associação dos moradores torna essa relação ainda mais ambígua e "institucionalizada" aos olhos dos moradores. É o que ocorre, por exemplo, quando o tráfico constrói a sede de uma associação ou uma piscina, administrada por ela.

Para alguns moradores, a própria autoridade dos líderes comunitários emana, em última instância, do chefe do tráfico de quem dependem. Eventuais reclamações dos moradores são levadas ao tráfico pelos líderes comunitários e, diante da repressão policial que impossibilita os chefes do tráfico de manter contato direto com os moradores, exercendo uma atividade ao mesmo tempo panóptica e clientelista, a associação passa a ser o canal intermediário pelo qual chegam várias benesses provenientes dos traficantes, principalmente durante festas.

Mesmo os líderes comunitários assumidamente mais "envolvidos" com traficantes procuram desfazer a poluição contaminadora que enfrentam todos os que mantêm relações com o tráfico e tratam de transmitir a ideia de uma inevitável relação respeitosa e

257 ALVITO, Marcos. As cores de Acari: uma favela carioca. Rio de Janeiro: Editora FGV, 2001. p. 132. Sobre a relação entre líderes comunitários e os políticos, cf. Ibid. p. 135 et seq. Segundo Marcos Alvito, traficantes financiam bailes espetaculares enquanto parte de um orgulho comunitário: "Mal comparando, é como o tirano Pisístrato, que teria sido o responsável pela grandiosidade do festival das grandes panatenéias, de onde veio a se originar o teatro. Ninguém pensava, em Atenas, postular uma relação entre a deusa Palas Atene e o tirano Pisístrato. Mas a relação entre o tirano Pisístrato e a comunidade, a intenção dele em reforçar esse vínculo, em se apresentar como campeão do orgulho comunitário, fazia com que ele engrandecesse as festas das grandes panatenéias (...) Um orgulho comunitário que não aceita mais as imagens que eram produzidas, da favela singela, ou da favela exótica, de barracão de zinco, ave-maria no morro, que agora diz assim: "Também não queremos que ninguém produza as imagens, nós mesmos vamos produzir uma representação sobre nós”. Olívia Cunha lembra, por sua vez, que o fato de os bicheiros financiarem as escolas de samba já foi de alguma forma legitimado e é consumido por nós todos como fazendo parte da estrutura ou do mundo do samba. Ninguém nunca se perguntou quem é que paga as rodas de pagode, de samba e outras atividades comunitárias (DEBATE 7 - Organizações comunitárias, cultura popular e violência II. In: ALVITO, Marcos; VELHO, Gilberto. Cidadania e Violência. Rio de Janeiro: UFRJ e FGV, 1996. p. 354-356). 
complementar entre dois chefes que ocupam "espaços" distintos. Se os líderes comunitários representam o tráfico junto aos moradores, o inverso também é verdadeiro. Se determinados vínculos de parentesco e/ou amizade os tornam pessoas "de confiança" para o "traficante", esses mesmos vínculos também são invocados para limitar o escopo da ação do chefe do tráfico. ${ }^{258}$

Traficantes, como Elias Maluco, já admitiram que são eles quem realmente financiam os bailes de comunidade, mas que não ganham nada com isso, apenas a "alegria dos moradores". Dada a popularidade do funk, a realização dos bailes não passaria de mais uma ação empregada pelos traficantes para ganhar o respeito e o apoio da comunidade, mas não só, conforme será visto nas páginas seguintes. ${ }^{259}$ Já as milícias, grupos de policiais que expulsam traficantes de favelas para cobrar uma taxa compulsória de segurança dos moradores, além de controlar a venda de diversos serviços, como transporte, gás e TV a cabo clandestina, ora proíbem os bailes funk, ora o realizam, com o mesmo intuito de ganhar respeito na comunidade. ${ }^{260}$

Independentemente de o tráfico estar pagando ou não bailes comunitários, o que deve ser levado em conta é a evidente e ávida demanda por lazer nas comunidades. Quando a festa é de interesse da comunidade e promovida pelo poder público ou alguma ONG, "bocas" são fechadas para sua realização. O eventual custeio de um baile de comunidade por um traficante pode ser explicado pela dificuldade de soluções de mercado para o lazer de boa parte das populações jovens das periferias, pelas relações afetivas traficante/comunidade e pela ausência de ações sistemáticas dos poderes públicos nesse campo.

\footnotetext{
${ }^{258}$ ALVITO, Marcos, op. cit. p. 151 et seq. Zuenir Ventura ilustra bem como era próxima a relação entre o presidente da associação dos moradores de Vigário Geral e o chefe do tráfico local (VENTURA, Zuenir, op. cit. p. 101 et seq.), bem como a relação entre o presidente da escola de samba de Parada de Lucas e o chefe do tráfico local (Ibid. p. 174-175). Os traficantes, entretanto, negam a interferência na associação dos moradores e dizem que só querem que ela "faça algo pela comunidade" (Ibid. p. 209, 245-246).

${ }^{259}$ ESSINGER, Silvio, op. cit. p. 183-184.

${ }^{260}$ As Unidades de Polícia Pacificadora, implantadas em algumas favelas do Rio de Janeiro a partir de dezembro de 2008, também tiveram uma postura repressiva em relação aos bailes. Apenas em 2010 foi liberado o primeiro baile funk "pacificado", na Ladeira dos Tabajaras, e mesmo assim, com diversas restrições. Estive neste baile no dia $1^{\circ}$ de janeiro de 2011, não vi armas, drogas, pessoas fazendo sexo nem ouvi "proibidões". No entanto, o sargento que comandava a tropa da UPP naquela noite me passou uma imagem muito negativa do funk. Disse que o baile da Ladeira dos Tabajaras havia sido proibido porque era financiado pelos traficantes e que, mesmo com a instalação da UPP, cuja sede fica ao lado da quadra onde é realizado o baile, são comuns as brigas e quebra-quebras na saída do baile, bem como o desrespeito às restrições impostas para que o baile seja permitido. Naquela noite, um dos organizadores havia sido levado à delegacia por furto de energia pública.
} 
Conforme aponta Manoel Ribeiro, enquanto o Estado não ocupar esses espaços, é complicado dizer para a senhora viúva que não coma da cesta básica que o "dono do morro" distribui, dizer para a comunidade para não participar de bailes, shows e distribuição de brindes, pagos "não se sabe por quem” e dizer às equipes de som "vejam lá de onde vem o dinheiro que paga os seus serviços" ou "vai lá e diz que você não toca pra bandido". ${ }^{261}$ Todavia, ao invés do Estado financiar ele próprio a realização dos bailes, no contexto de uma política cultural e recuperar uma função que, diante de sua omissão, acabou sendo preenchida pelo tráfico, adotou-se uma política repressiva, de proibição desses bailes, encarados como caso de polícia.

Outras evidências de que os bailes de comunidade seriam financiados pelo tráfico são a ausência de brigas, como as ocorridas nos bailes de clube, a presença de traficantes armados na pista, o consumo livre de drogas e os chamados "proibidões", funks que supostamente fazem apologia ao crime e que são cantados nestes espaços. A presença de traficantes armados nos bailes funk de comunidade também se explica pelo simples fato de as identidades não serem rígidas. Os frequentadores de baile funk não constroem necessariamente para si mesmos a identidade de "funkeiros", haja vista que gostam de outros ritmos musicais e que o funk é apenas o ritmo preferido para dançar, razão pela qual não se deve tomar as letras "como narrativas fidedignas do universo e do cotidiano do jovem que frequenta o baile funk e mora na favela". 262

Da mesma forma, os traficantes possuem múltiplas identidades: pais, filhos, amigos, surfistas, namorados, funkeiros, pagodeiros, cristãos, etc. Se o traficante é um jovem como qualquer outro da comunidade, que também gosta de funk e de se divertir, por que deixará de ir ao baile? Conforme explica Vianna, esses grupos têm estilos de vida híbridos. As roupas e gírias usadas nos bailes são também parte integrante do estilo de vida

\footnotetext{
${ }^{261}$ RIBEIRO, Manoel. "Funk'n Rio: vilão ou big business?" In: Revista do Patrimônio Histórico e Artístico Nacional, n. 24. Ministério da Cultura, IPHAN, 1996. p. 291.

${ }^{262}$ CUNHA, Olívia M. G. Conversando com Ice-T: violência e criminalização do funk. In: HERSCHMANN, Micael (Org.). Abalando os anos 90: funk e hip-hop - globalização, violência e estilo cultural. Rio de Janeiro: Rocco, 1997. p. 93; VIANNA, Hermano, op. cit. p. 91-92. Quem frequenta o baile não é um único tipo de jovem. Entre os funkeiros, existe uma maioria que estuda e/ou trabalha e que curte também outro tipo de música. O funk não é uma unanimidade entre os jovens da comunidade, pelo menos entre os "alternativos" (SANSONE, Livio. Funk baiano: uma versão local de um fenômeno global? In: HERSCHMANN, Micael (Org.). Abalando os anos 90: funk e hip hop: globalização, violência e estilo cultural. Rio de Janeiro: Rocco, 1997. p. 173). Zuenir Ventura menciona em diversas passagens de Cidade Partida o gosto dos traficantes e dos jovens de Vigário Geral, como um todo, pelas músicas de Raul Seixas (VENTURA, Zuenir, op. cit. p. 62, 74 et seq., 112).
} 
das gangues de traficantes e ladrões cariocas. Nem todos os bandidos do Rio frequentam o mundo funk, mas existem relações entre os dois mundos, como entre o funk e o pagode. ${ }^{263}$

Tanto a identidade de traficante quanto a de funkeiro são estigmas que parecem querer, sem sucesso, englobar todos os momentos de vida desses jovens e que só foram assumidos como identidades por eles como resultado do processo de rotulação social. Frequentando os bailes funk, é natural que o traficante ande armado. Primeiramente, para fazer a segurança da favela e pela própria necessidade essencial de andar sempre armado para "garantir o cumprimento dos contratos" em um mercado ilegal e se proteger de eventuais traições na cadeia hierárquica do tráfico. ${ }^{264}$ Em segundo lugar, a arma demonstra poder, confere status aos jovens, segundo o ethos de masculinidade, e exerce um verdadeiro fascínio em algumas meninas, inclusive de classe média, as "caça-fuzil", que sobem o morro atrás de "bandidinhos".

\subsection{Baile funk e drogas}

Uma parte do intercâmbio entre asfalto e morro que acontece no baile funk e seus arredores gira em torno do consumo ao ar livre de cocaína e, em menor medida, de maconha, ou seja, os jovens, inclusive adolescentes, sobem o morro para fazer o que não podem no asfalto. Uma parte da paquera entre meninos do morro e de meninas do asfalto também utiliza a cocaína como atrativo. ${ }^{265}$ Não importa tanto, porém, na óptica da criminologia crítica, o fato de que há consumo de drogas nos bailes funk, mas sim questionar se o consumo de drogas justifica o fechamento dos bailes, uma vez que o fechamento das bocas de fumo, cuja localização é conhecida por todos, faria muito mais sentido. $^{266}$

\footnotetext{
${ }^{263}$ VIANNA, Hermano, op. cit. p. 104. O traficante não usa apenas a festa de que a comunidade gosta. Ele é parte dessa comunidade, é garoto como aquele outro que escuta funk desde criança, gosta de funk, também, gosta da festa e gostaria de participar. O DJ Marlboro já viu o próprio chefe do morro discotecando, armado e com dois seguranças (DEBATE 7, op. cit. p. 355-356).

${ }^{264}$ ZALUAR, Alba. A máquina e a revolta: as organizações populares e o significado da pobreza. São Paulo: Editora Brasiliense, 1985. p. 151-152. "A gente anda mesmo porque, vamos dizer assim, necessita de andar armado. Eu não posso largar aquilo ali não. Eles querem me segurar" (VENTURA, Zuenir, op. cit. p. 195). "Baile eu não vou não. Já fui a muitos, mas na fase que tá, que tão me queimando mesmo, aí eu não posso ficar dando mole. Eu vou aqui no baile do União" (Ibid. p. 202).

${ }^{265}$ Sansone acredita, porém, baseando-se na sua pesquisa de campo, que a mistura sociorracial do baile é exagerada pelos entusiastas do funk e que, consequentemente, também são exageradas as estimativas de jornalistas, traficantes e da imprensa em relação aos lucros das bocas de fumo (SANSONE, Livio, op. cit. p. 172). Cf. também RESENDE, Juliana. Operação Rio. São Paulo: Editora Página Aberta, 1995. p. 64-65.

266 "Essa rapaziada que ta aí é tudo avião. Aqui não bate casos importantes. Se eles quisessem mesmo acabar com o negócio, iam prender na raiz, na fonte. É um negócio complicado onde o pobre segura a descarga.
} 
A "Guerra contra as Drogas" tem uma função política muito clara de ampliar os poderes punitivos do Estado e o controle social, criminalizar e demonizar populações inteiras, as mesmas de sempre (negros, pobres, imigrantes). Por outro lado, legitima até interferências militares e político-econômicas em países produtores (ou supostamente produtores) da droga, obrigados a exercer esse papel justamente pelo capital financeiro, pela nova divisão internacional do trabalho, pelas crises econômicas e novas políticas de ajuste econômico, as quais favorecem a expansão dessa produção voltada para o comércio globalizado. $^{267}$

Para Maria Rita Kehl, o tráfico de drogas não é antagônico às economias de mercado: é sua extensão selvagem. As sociedades ditas liberais convivem com ele por uma afinidade lógica: os lucros astronômicos formados com base em trabalho escravo (voluntário) falam a mesma língua de outras formas de acumulação acelerada de capital. O tráfico, como o capitalismo, produziria os sujeitos dos quais se alimenta. De um lado, no asfalto, estão os consumidores do único meio de gozo tão potente que dispensa a publicidade. Do outro lado, o da linha de montagem e da distribuição, está um exército de escravos, pois quem entra, só sai morto. ${ }^{268}$

A proibição das drogas leva a um sobrepreço que faz com que valha a pena para o traficante correr riscos. Por tratar-se de mercado altamente lucrativo e não-regulado, quadrilhas rivais disputam espaços à bala, e os que triunfam têm poder econômico para corromper policiais e outros agentes do Estado. ${ }^{269}$ A expansão dos mercados consumidores

Uma vez eu peguei no jornal o mapa com todas as bocas de fumo. Se a polícia sabe por que não vai lá acabar com a parada?" (SILVA, Bezerra da. Discursos sediciosos entrevista Bezerra da Silva. In: Discursos sediciosos: crime, direito e sociedade, ano 4, n. 7/8. Rio de Janeiro: Instituto Carioca de Criminologia, 1999. p. 15). Moradora de uma casa em frente à quadra em que se realizava o baile do Chapéu-Mangueira, Benedita da Silva revelava que seus sobrinhos e netos eram alguns dos mais assíduos frequentadores da festa: "é uma maldade vincular o funk à boca-de-fumo. O tráfico na Vieira Souto não é diferente do que se vê no Chapéu Mangueira (...) Todo mundo sabe onde funciona a boca-de-fumo. É uma desfaçatez do poder público, que não dá jeito no tráfico" (ESSINGER, Silvio, op. cit. 134-135). Com os bailes interditados, o tráfico continuou e se conseguiu acabar com uma das raras formas de lazer dos jovens das favelas (HERSCHMANN, Micael, op. cit. p. 178).

${ }^{267}$ DUMANS, Alexandre Moura; BATISTA, Vera Malaguti. Nada de novo no front. In: Revista Ciência Hoje, São Paulo, n. 181, abril 2002. A guerra contra as drogas privilegia o aspecto punitivo e tem como alvo principal os negros. Nos guetos, o tráfico é a fonte de emprego mais acessível, a presença policial é mais densa e os habitantes são mais impotentes, o que facilita a seletividade desproporcional da população negra como principal usuária de drogas. A repressão demagógica aos drogados e traficantes tem resultado, no entanto, em um grande fracasso, haja vista que as quantidades de droga em circulação aumentaram, bem como o número de pessoas encarceradas (WACQUANT, Loïc. Punir os pobres: a nova gestão da miséria nos Estados Unidos. Rio de Janeiro: Freitas Bastos, 2001. p. 29-30).

${ }^{268}$ KHEL, Maria Rita. As asas quebradas. Folha de S. Paulo, São Paulo, 26 março 2006. Caderno Mais.

${ }^{269}$ Cf. RODRIGUES, Luciana Boiteux de Figueiredo. Controle penal sobre as drogas ilícitas: o impacto do proibicionismo no sistema penal e na sociedade. 2006. Tese (Doutorado)-Departamento de Direito Penal, Medicina Forense e Criminologia, Universidade de São Paulo, São Paulo, 2006. p. 195 et seq. 
de drogas ilícitas, obedecendo à lógica das relações econômicas capitalistas, é fator determinante da produção, abrindo novas oportunidades de acumulação de capital e de geração de empregos e, assim, suprindo as limitadas oportunidades oferecidas pelas atividades econômicas lícitas. Afinal, onde houver demanda, haverá oferta. ${ }^{270}$

Em nosso país, a maioria dos condenados por tráfico de entorpecentes, que lotam nossas cadeias, não são os verdadeiros "chefões" das drogas, mas jovens negros e pobres recrutados pelo mercado ilegal graças à falta de oportunidades imposta pelo modelo econômico ao qual estamos submetidos. ${ }^{271} \mathrm{~A}$ indústria do crime segue exatamente a mesma racionalidade de acumulação de capital que a das empresas vencedoras do mercado lícito. Assim como qualquer empresa, a indústria do crime se organiza para atender a uma demanda existente, almeja o acúmulo de capital, pode assumir grande escala produtiva, recruta e treina mão-de-obra, estabelece focos territoriais de oferta e procura, faz lobby na imprensa e na política, questiona o poder decisório do Estado e investe em responsabilidade social.

A indústria do crime ainda tem um papel fundamental para movimentar a economia, já que aciona recursos diretos e indiretos para produzir e distribuir seu produto, estende suas teias para negócios complementares e gera emprego e renda, tanto diretamente quanto indiretamente, inclusive na correspondente indústria do controle do crime. ${ }^{272}$ Responsabilizar de forma moralista o baile funk pelo tráfico de drogas e encarar o traficante como o malfeitor que "desvirtua nossas crianças" é, portanto, mais cômodo e funcional do que enxergar e combater o tráfico em toda a sua dimensão políticoeconômica. ${ }^{273}$ Alguns Acórdãos transparecem uma visão criminalizante do baile funk que o associa ao ambiente propício para a prática do tráfico de drogas. O fato de o "suspeito" estar se dirigindo a um baile ou se encontrar em suas cercanias é considerado um indício que aumenta as suspeitas:

\footnotetext{
${ }^{270}$ KARAM, Maria Lúcia. Drogas ilícitas e globalização. The Narco News Bulletin, n. 30, maio 2003.

${ }^{271}$ DUMANS, Alexandre Moura; BATISTA, Vera Malaguti, op. cit. O MC Mr Catra nega que o funk esteja sob o comando do tráfico organizado: "Quer acabar com o tráfico de drogas? Libera as drogas (...). Arruma emprego para aquela molecada que tá lá no tráfico. Ou então libera as drogas e deixa os caras mesmo que estão lá traficando. Tira o revólver das mãos dos caras e põe eles atrás do balcão. Anistia os traficantes e transforma o crime em firma" (Apud ESSINGER, Silvio, op. cit. p. 236).

272 PIVA, Luiz Guilherme. A economia do crime. Revista Consultor Jurídico, São Paulo, 24 de maio de 2006. Sobre a indústria do controle do crime, cf. CHRISTIE, Nils. A indústria do controle do crime. Rio de Janeiro: Forense, 1998.

${ }^{273}$ MORETZSOHN, Sylvia. O caso Tim Lopes: o mito da "mídia cidadã". In: Discursos Sediciosos: crime, direito e sociedade, vol. 12. Rio de Janeiro: Editora Revan, 2002. p. 304-305.
} 
0034729-79.2002.8.19.0001 (2002.050.04185) - APELACAO

DES. MARIA HELENA SALCEDO - Julgamento: 18/03/2003 - SETIMA CAMARA CRIMINAL

Note-se que com a menor Joice, que também usa o nome Luana, foram apreendidos outros quarenta e um sacolés da mesma erva, com o peso de $46 \mathrm{~g}$ (quarenta e seis gramas), sendo certo que os três estavam juntos e dirigiam-se a um baile "funk" no Morro do Turano (...) Ademais, as circunstâncias da prisão, a conduta dos elementos, o liame subjetivo existente entre os mesmos e que restou devidamente evidenciado, apontam, igualmente, para o crime contido no artigo 12, c/c 18, III, da Lei 6368/76.

0034701-17.2002.8.19.0000 (2002.050.05724) - APELACAO

DES. NILZA BITAR - Julgamento: 02/09/2003 - QUARTA CAMARA CRIMINAL

Os apelados foram presos em local conhecido pela (sic) tráfico de drogaspróximo a um baile funk- que o Delegado que prestou as declarações de fls. 105 conhece como tal (...) Os policiais declararam que os meliantes deviam conhecêlos, pois patrulhavam sempre o local, sendo que uma vez quase foram mortos no baile "Funk" ali realizado. Honestamente admitiram não conhecer o grupo antes dos fatos, e que tiveram sua atenção despertada pela atitude suspeita deles. A forma como a droga foi apreendida é outro indicativo do tráfico.

0036602-54.2001.8.19.0000 (2001.050.02211) - APELACAO DES. NILDSON ARAUJO DA CRUZ - Julgamento: 26/02/2002 - PRIMEIRA CAMARA CRIMINAL

Pondere-se, agora, a causa especial de aumento da pena, que, para o Ministério Público, foi aquela do art. 18, III, segunda parte. Eis como a inicial a descreveu: "Consta, ainda, que no momento da prisão, os dois se encontravam dentro de um táxi, e traziam farto material para endolar a droga, e diversos convites para um baile "Noite das Popozudas" realizado nesta mesma comarca no dia 16.09.2000. A ação dos denunciados foi dirigida, finalisticamente, a trazer consigo, para a venda, substância entorpecente, sem qualquer autorização legal, visando menores de 21 anos frequentadores daquele baile." A propósito, a sentença fez as seguintes considerações: "Foi apreendido o entorpecente em poder dos acusados, como acima examinado, os quais traziam consigo ainda uma grande quantidade de convites para o baile "Noite das Popozudas", onde, como também observado, provavelmente seria distribuído o tóxico. Ocorre que, caso menores de vinte e um anos efetivamente frequentassem o baile em tela, não passaria de especulação concluir que adquiririam entorpecente dos acusados, sendo insuficiente a prova carreada à incidência da supra mencionada agravante. Se assim não fosse, o tráfico praticado em via pública estaria sempre sob a incidência da circunstância agravante pretendida pelo Parquet, pois menores de vinte e um anos têm livre trânsito pelas ruas. No entanto, apesar da capitulação contida na denúncia, a exordial narra que a ação dos acusados se destinava aos frequentadores do baile "Noite das Popozudas" encontrando-se esta circunstância descrita como causa de aumento da pena no inciso IV, do artigo 18 da Lei $n^{\circ}$ 6368/76, vale dizer, se destinar o entorpecente à venda nas imediações de recintos onde se realizam espetáculos ou diversões de qualquer natureza. $\mathrm{O}$ tema já foi examinado acima, quando se verificou que juntamente ao entorpecentes foram apreendidos 226 convites para o baile, organizado pelo segundo réu. A prova, portanto, é forte no sentido de que o tóxico seria distribuído naquele evento, devendo incidir a mencionada causa de aumento da pena." Em que pese o entendimento da eminente Juíza de Direito Ana Luíza Coimbra Mayon Tovil, revelador de um cuidadoso e reflexivo exame da prova, vejo-me, entretanto, na contingência de, no particular, dissentir de S. Ex. a . É que, na minha forma de pensar, que trago à deliberação deste E. Colegiado, concluir, por causa dos convites, que a droga iria ser vendida no baile, não encerra um juízo de certeza, mas, de mera suposição, exatamente igual aqueloutra quanto à 
venda para menores, expressada, na medida exata, pela sensível Julgadora. Além disso, o inciso IV do art. 18 exige, para a configuração da causa especial, que "qualquer dos atos de preparação, execução ou consumação" ocorra "nas imediações ou no interior de (...) recintos onde se realizem espetáculos ou diversões de qualquer natureza, sem prejuízo da interdição do estabelecimento." A meu ver, o fato não se ajusta ao modelo legal. Com efeito, os apelantes foram presos em flagrante, dentro de um táxi, no dia 6 de setembro de 2000 e o baile seria realizado no dia 16 daquele mês e ano. Assim sendo, não ocorreu qualquer ato de preparação, de execução ou de consumação no local onde iria ocorrer a festa. Se havia o intuito dos apelantes de traficarem o material ali- e, quiçá, até poderia haver, isto, contudo, não é suficiente para a configuração da causa especial de aumento da pena, que exige atos concretos, repita-se, de preparação, de execução ou de consumação nos locais que menciona e, pelo menos para mim, nenhum deles ocorreu.

0102116-72.2006.8.19.0001 (2007.052.00030) - REEXAME NECESSARIO DES. SUELY LOPES MAGALHAES - Julgamento: 31/05/2007 - OITAVA CAMARA CRIMINAL

Recurso Criminal ex-officio. Aluguel de equipamento de som pelo recorrido, apreendido por policiais militares do $2^{\circ}$ Batalhão, e encaminhados à DP, juntamente com dois funcionários da empresa. A apreensão do material vem impedindo que a empresa exerça sua atividade comercial, causando-lhe prejuízo. Apesar das várias ações visando reprimir os bailes na comunidade do Morro Dona Marta, frequentado por menores, com uso de drogas e som bastante elevado durante a madrugada, a empresa recorrida apenas aluga e instala os equipamentos, e não pode ser responsabilizada pelos atos decorrentes da reunião incivilizada. $\mathrm{O}$ douto Juízo confirmou a liminar anteriormente concedida, concedendo a posse definitiva dos bens à recorrida, devendo ser improvido o presente recurso.

\section{4-96.2007.8.19.0038 (2008.050.05205) - APELACAO \\ DES. ANTONIO JOSE CARVALHO - Julgamento: 26/02/2009 - SEGUNDA CAMARA CRIMINAL}

(...) As condições em que o injusto penal ocorreu, inclusive quanto ao local, demonstram a veracidade da imputação. Dizem os policiais militares: “(...) que chegando ao local avistaram o acusado vestindo blusa vermelha, bermuda vermelha e boné vermelho; (...) que o bairro é dominado pelo Comando Vermelho; ....; que a localidade é conhecida como ponto de venda de drogas;" (Cb. PM WANDER, fls. 65) “(...) que ao chegar ao local percebeu a existência de um baile Funk; ...; que o depoente prendeu sua atenção no réu; (...) (Sgt. PM VICTOR, fls. 66) (...) As provas produzidas (...), bem como da culpabilidade do Apelante que, em razão da diversidade, quantidade e forma de embalagem das drogas e, até mesmo das suas vestes, que claramente remetem à de um integrante da facção criminosa conhecida como "Comando Vermelho", que, como sabido, utiliza-se da realização de bailes "funk" em comunidades carentes para mais comercializar as substâncias tóxicas e até fazem com que alguns dos integrantes da organização criminosa vistam-se de vermelho, para serem identificadas pelos usuários e viciados, mostram-se bem mais que suficientes para sustentar o decreto condenatório.

Bailes e tráfico de drogas são atividades que podem se encontrar, mas são independentes, tanto é que o tráfico já existia antes do funk e permaneceu mesmo após a proibição dos bailes. A presença de traficantes em bailes como o do Chapéu-Mangueira, que congregava em torno de cinco mil jovens por fim de semana, muitas vezes era para 
garantir não a segurança especificamente do baile, mas do morro como um todo, alertando sobre a presença de policiais ou traficantes rivais em um dia de grande movimento. ${ }^{274}$

A não ser que as drogas sejam distribuídas gratuitamente pelos traficantes, o seu consumo e até o consumo de álcool pode ser escasso nos bailes funk em decorrência do baixo poder aquisitivo de seus frequentadores. Alguns chegam a pegar copos usados para apanhar água da torneira. ${ }^{275}$ Também convém questionar, numa perspectiva crítica, por que estes bailes são alvos da polícia e não as boates da Zona Sul, onde é sabido que jovens das camadas sociais mais abastadas consomem drogas. Será o consumo de drogas nos camarotes do carnaval de Salvador proporcionalmente menor do que o consumo de drogas na aglomeração da "pipoca", onde todo ano são captadas imagens de violência policial? ${ }^{276}$

A história social mostra que não existe comunidade humana que não registre experiências de consumo de substâncias que provocam alterações significativas dos estados da consciência e da personalidade. Assim como as condutas criminosas são fruto de um processo de criminalização historicizado, o conceito de droga ilícita também é relativo. Inúmeras substâncias proscritas em determinados contextos históricos e locais são de uso em outras culturas, locais e tempos, como o chocolate e o café. Pesquisa quantitativa e qualitativa realizada por Minayo et alii constatou que se encontram maiores proporções de jovens de classe média/alta que já experimentaram/usaram drogas do que os das camadas populares, especialmente maconha. O consumo de álcool em ambos os estratos cresce com a idade.

As proporções dos que já experimentaram cocaína é crescente com a idade, nas camadas populares, sendo bem significativas nas faixas de 19 e 20 anos. O ecstasy, por sua vez, é nomeado pelos rapazes praticantes de jiu-jítsu, mostrando ser essa uma droga "elitizada", cujo consumo é importado da Europa e de pouco conhecimento popular, pelo menos na época da pesquisa. Os depoimentos dos diferentes grupos de jovens evidenciaram que existe facilidade de acesso às drogas consideradas ilícitas no Rio de

${ }^{274}$ HERSCHMANN, Micael, op. cit. p. 128-129.

${ }^{275}$ VENTURA, Zuenir, op. cit. p. 125. "Como grande parte do público tem até que economizar seu dinheiro para comprar a entrada do baile, não sobra nada para gastar com bebidas. Muita gente passa a festa inteira sem beber. Também não existe um consumo ostensivo de maconha ou cocaína, como é comum em boates ou shows de rock na Zona Sul. Pouquíssimas foram as vezes em que percebi indícios de consumo de drogas dentro dos bailes" (VIANNA, Hermano, op. cit. p. 75).

${ }^{276}$ Mr. Catra provoca:“Antigamente a favela até influenciava o crime no asfalto, hoje em dia não, o asfalto tem seu próprio crime, entende? (...) Já estão com o crime deles que é o ecstasy, que é o ácido, que é as raves. A gente tem os bailes funk, os caras têm a rave. Quem que lucra mais, uma boca no baile funk ou uma boca numa rave? Hã? Me diz aí? Um papelote de cocaína é R \$ 50 no máximo, uma bala é R \$ 50" (BATISTA, Vera Malaguti; BATISTA, Carlos Bruce; BORGES, Rafael C. Entrevista com Mr. Catra. In: Discursos sediciosos: crime, direito e sociedade, $\mathrm{n}^{\circ}$ 15/16. Rio de Janeiro: Editora Revan, 2007. p. 13). 
Janeiro, na medida em que estão disponíveis em todos os locais onde a sua vida social transcorre, como a praia, o shopping, os shows, as discotecas e o colégio. ${ }^{277}$

Ainda que jovens de classe média e alta se queixem de eventuais incursões policiais em shows de rock e raves, onde o consumo de drogas é comum, a prisão de jovens dessa camada social trata-se mais de exceção do que de regra. Há um histórico de atritos entre a polícia e a juventude que vem desde a ditadura militar e se prolonga pela redemocratização. Ao desempenhar o papel de mantenedora da ordem pública, a polícia, julgando-se insultada, causava atritos em shows de rock e, após revistas truculentas, prendia jovens, principalmente os mais pobres, sob a acusação de consumo, porte ou incitação ao uso de drogas.

Enquanto a população mais idosa e conservadora afirma que "tem polícia de menos", muitos jovens sentem na pele que "tem polícia demais" e as bandas musicais a elegem como alvo de suas críticas. Por outro lado, a polícia faz muitas vezes vista grossa àqueles que, devido à proteção da aglomeração humana nos shows de rock, transformavam esses locais em espaço para o livre consumo de drogas. ${ }^{278} \mathrm{Na}$ época da ditadura, a vista

\footnotetext{
${ }^{277}$ MINAYO, Maria Cecília de Souza et alii. Fala, galera: juventude, violência e cidadania no Rio de Janeiro. Rio de Janeiro: Garamond, 1999. p. 75 et seq.
}

${ }^{278}$ CARMO, Paulo Sérgio do. Culturas da rebeldia: a juventude em questão. São Paulo: Editora SENAC, 2001. p. 153-154. As raves começam na Inglaterra, no final da década de 80. Eram festas ilegais, realizadas em prédios abandonados ocupados por estudantes ou desempregados ou em sítios nos arredores das grandes cidades. A divulgação era feita "boca-a-boca", por meio de flyers e rádios piratas. Para despistar a polícia, que queria impedir a proliferação dessas festas, que reuniam multidões, era comum essas rádios ou os organizadores, por telefone, anunciarem a festa e darem apenas algumas pistas de como chegar, indicando um lugar no meio do caminho, como um posto de gasolina no meio da estrada, onde haveria uma pessoa dando o resto do endereço. $\mathrm{O}$ tamanho da massa reunida tornava a polícia impotente para deter o comboio seguindo em direção à festa. Movimentações como essa apontam o divertimento dos ravers em brincar de desafiar as regras sociais e o perigo. Curiosamente, embora movidos por propósitos bem diferentes, essa tática não é muito diferente da adotada pelos estudantes brasileiros na época da ditadura militar para organizar congressos clandestinos. Mesmo com todo esse esquema para manter as raves longe dos olhos do governo e da polícia, em 1992, o mesmo ano do arrastão do Arpoador, a histórica Spiral Tribe, em Castlemorton, Worcestershire, jogou todos os holofotes em cima da cena. A festa reuniu cerca de 40 mil pessoas, durou seis dias e causou indignação na conservadora e moralista sociedade britânica. Equipes de TV e jornais noticiaram o evento, abrindo espaço para a repressão do governo, que, dois anos depois, fechou o cerco às festas ao ar livre com música eletrônica regadas a ecstasy. Aliás, realizar-se ao ar livre, embalada a música eletrônica e ecstasy são as três condições que caracterizam uma festa rave em qualquer lugar do planeta (ABREU, Carolina de Camargo. Raves: encontros e disputas. 2005. Dissertação (Mestrado)Faculdade de Filosofia, Letras e Ciências Humanas, Universidade de São Paulo, São Paulo, 2005. p. 19, 28). $\mathrm{O}$ uso de psicoativos nas raves é essencial para a pessoa entrar na vibe, um transe, um estado de emoções e sensações apenas reprodutível coletivamente, uma espécie de comunhão moral e efervescência coletiva durkheimiana (Ibid. p. 24). As raves chegaram ao Brasil em meados da década de 90 , quando a cena londrina já entrava em decadência por conta da perseguição policial. Ao contrário do que ocorreu na Inglaterra, em que elas sempre foram eventos marginais, no Brasil a primeira rave foi organizada por uma empresa. Em 1998 essas festas tornaram-se eventos semanais de jovens paulistanos, geralmente provenientes das classes média e alta, que chegavam a reunir regularmente 2 mil participantes em média (Ibid. p. 34 et seq). Originalmente, os ravers apareceram para eliminar todas as diferenças entre idade, sexo, classe ou condição social e são um produto de um escapismo surgido em face das dificuldades advindas de uma sociedade pós- 
grossa também era explicada pela preferência do regime militar por uma juventude "desbundada" a uma juventude guerrilheira. Atualmente, além da corrupção, a vista grossa das autoridades policiais e políticas sobre o consumo de drogas por jovens de classe média e alta ocorre em virtude da própria seletividade do Direito Penal, que deixa impunes os que possuem poder político e econômico e pune com rigor os que são mais vulneráveis às suas garras, ou seja, os marginalizados.

Policiais entrevistados elaboram um discurso ressentido, no qual projetam uma concepção peculiar de que a única forma de aproveitar os privilégios recebidos pelos rapazes e moças de classe média e alta seja a delinquência. A menção aos desmandos dos "filhinhos de papai" aparece fortemente associada às transgressões de comportamento como dirigir em alta velocidade, fumar maconha ou cheirar cocaína, causar brigas e tumultos nos bailes e discotecas. Como esses jovens pertencem a famílias de alto poder aquisitivo e gozam de "influência na sociedade", ficam imunes ao exercício da lei. Neste caso, mesmo cumprindo a lei, é o policial que acaba sendo punido. ${ }^{279}$

\subsection{As relações ambíguas entre "bandidos", MCs e "otários"}

A presença de traficantes armados nos bailes de comunidade não demonstra necessariamente, a não ser em uma visão demasiadamente estreita, a associação dos traficantes com os MCs ou DJs. Um olhar etnográfico, que atente para as especificidades das tramas de relações sociais existentes nas comunidades, revelará que a amizade com traficantes não implica necessariamente em cumplicidade com a prática criminosa. Diante da falta de perspectivas colocada à juventude pobre, negra e favelada brasileira, é esperado que alguns jovens dessas comunidades não resistam à tentação de ingressar no tráfico para alcançar bens de consumo e status junto a mulheres.

É mais fácil, porém, acusar o funk de "arregimentar mão de obra para o tráfico" do que reconhecer que o próprio modelo econômico faz com que haja uma fila de jovens desempregados e sem qualificação profissional se oferecendo para trabalhar na estrutura de

industrial com altos índices de desemprego (SHECAIRA, Sérgio Salomão. Criminologia. São Paulo: Revista dos Tribunais, 2004. p. 258).

${ }^{279}$ MINAYO, Maria Cecília de Souza et alii. Fala, galera: juventude, violência e cidadania no Rio de Janeiro. Rio de Janeiro: Garamond, 1999. p. 173-174, 179. As violações e crimes dos estratos médios e altos da sociedade permanecem na invisibilidade, sob a imagem de que por natureza são sujeitos morais acima de qualquer julgamento, com direito de serem protegidos e salvos de humilhações, degradações e sofrimentos (Ibid. p. 190). 
varejo do comércio de drogas. ${ }^{280}$ De acordo com Jock Young, a criminalidade é resultado da privação relativa e do individualismo, sendo que ambos os fatores foram realçados na pós-modernidade. A privação relativa consiste na sensação de injustiça em relação à desigualdade social, ou seja, na sensação de que a desigualdade social não decorre da meritocracia, mas, ao contrário, de sua falta. A contradição entre a incorporação das metas culturais de consumo de uma sociedade e a impossibilidade de se alcançar por meios lícitos estas metas, em decorrência da estrutura social, constitui uma motivação criminógena poderosa. $^{281}$

Segundo a teoria da anomia, de Robert Merton, a contradição entre as metas culturais de ascensão social e consumo na sociedade capitalista e as capacidades socialmente estruturadas de atingi-las de forma lícita pode gerar cinco tipos de comportamentos individuais: o conformista, o tipo mais comum em uma sociedade, conforma-se tanto com as metas culturais quanto com os meios institucionalizados.; o ritualista, que renuncia aos objetivos valorados por ser incapaz de realizá-los, mas segue compulsivamente as normas institucionais; o retraído, como o mendigo e o toxicômano, que renuncia tanto às metas culturais quanto às normas sociais; o rebelde propõe novas metas culturais e a institucionalização de novos meios para atingi-las; e, por fim, o inovador, que adere às metas culturais de consumo e ascensão social, mas renuncia aos meios legítimos para atingi-las, ou seja, inova ao adotar meios ilícitos, criminosos. ${ }^{282}$

O comportamento humano é baseado em valores que guiam o indivíduo. Há, portanto, uma correlação inevitável entre os valores sociais de uma determinada comunidade histórica concreta e a criminalidade da referida comunidade. Por isso, qualquer projeto sério de prevenção criminal a médio ou longo prazo exige uma revisão profunda do marco axiológico ou da escola de valores sociais. A criminalidade dos jovens é "aprendida" na sociedade dos adultos, na qual há um flagrante divórcio entre os valores “oficiais", ideológicos, e os praticados, como violência, corrupção, falta de solidariedade etc.

O culto ao êxito econômico rápido, a todo custo, e a baixa tolerância à frustração geram mensagens ambíguas, pedagogicamente negativas, suscetíveis de uma leitura criminógena. Em uma sociedade que investe mais em jogos de azar que me gastos sociais,

\footnotetext{
${ }^{280}$ Cf. RIBEIRO, Manoel, op. cit. p. 292; MINAYO, Maria Cecília de Souza et alii, op. cit. p. 162.

281 YOUNG, Jock. A sociedade excludente: exclusão social, criminalidade e diferença da modernidade recente. Rio de Janeiro: Revan, 2002. p. 25 et seq.

${ }^{282}$ Apud SHECAIRA, Sérgio Salomão, op. cit. p. 224 et seq.
} 
é natural que os jovens acreditem mais no risco, na aventura, na audácia, em técnicas de empreendedorismo agressivas e heterodoxas ou em comportamentos delitivos mais rentáveis do que acreditem nos trabalho, no esforço pessoal e nas convenções. A criminalidade dos jovens é em grande parte subcultural justamente porque rechaça alguns valores da sociedade mais ampla, como o trabalho honesto, mas incorpora outros, como o consumismo. Uma política preventiva busca oferecer uma alternativa de valores ao jovem para que ele possa se comprometer com a mudança social, em detrimento de uma postura niilista. $^{283}$

Parte da criminalidade contemporânea é gerada "de fora para dentro" da favela e pode ser resumida em necessidade de poder, lazer e consumo. "A indústria cultural criou jovens que desejam ter acesso aos bens especialmente fabricados para eles, desde vestimentas e estilos musicais a drogas ilegais". Apesar de afirmarem que desdenham a vida dos "playboys" e das "patricinhas", os funkeiros da favela têm como referência o estilo de vida dos jovens surfistas da Zona Sul de classe média e alta e idolatram, inclusive nas letras das músicas, suas marcas de tênis e roupas. Há um intercâmbio comercial dinâmico em que o "asfalto" consome a cocaína da favela e esta, à sua maneira, a moda do “asfalto”. O problema, todavia, não se resume à dimensão econômica.

Há em jogo elementos culturais e simbólicos extremamente importantes. Os jovens rejeitam a disciplina do trabalho embrutecedor e são seduzidos esteticamente pela revolução pós-moderna da alta tecnologia e do show-business. É preciso, pois, substituir o fascínio causado pela tecnologia de uma AR-15 pela tecnologia de um laptop. ${ }^{284}$ Neste ponto, grande parte dos jovens atribui à propaganda televisiva o incentivo ao consumo

${ }^{283}$ GOMES, Luiz Flávio; GARCÍA-PABLOS DE MOLINA, Antonio. Criminologia. 7. ed. São Paulo: RT, 2000. p. 380-381.

${ }^{284}$ Segundo Alba Zaluar, a globalização e cultura de massa difundem novas necessidades. "A imagem do menino favelado com um AR-15 ou metralhadora UZI na mão, as quais considera como símbolos de sua virilidade e fonte de grande poder local, com um boné inspirado no movimento negro da América do Norte, ouvindo música funk, cheirando cocaína produzida na Colômbia, ansiando por um tênis Nike do último tipo e um carro do ano, não pode ser explicada, para simplificar a questão, pelo nível do salário mínimo ou pelo desemprego crescente no Brasil, nem tampouco pela violência costumeira do sertão nordestino" (Apud CARMO, Paulo César do, op. cit. p. 216). Cf. HERSCHMANN, Micael, op. cit. p. 153-155; VIANNA, Hermano, op. cit. p. 74; VENTURA, Zuenir, op. cit. p. 141, 179, 216-217; DEBATE 7, op. cit. p. 365-366. As roupas e aspirações de consumo dos jovens bandidos pouco a pouco se distinguem das mantidas pelos demais moradores. "Uma identidade geracional entra em ação e aproxima os bandidos dos jovens ricos no consumo de certos objetos, que marcam um estilo, e no gosto pelo tóxico" (ZALUAR, Alba, op. cit. p. 158). José Júnior, coordenador da ONG Afroreggae, declara que os jovens entram para o tráfico não só pelo dinheiro, mas porque o lugar mais legal numa favela à noite é a boca-de-fumo, onde "o som é maneiro, a galera é bem vestida...” (MORETZSOHN, Sylvia, op. cit. p. 300). 
supérfluo e, consequentemente, à entrada de muitos jovens pobres no mundo do tráfico de drogas para comprarem aquilo a que não teriam acesso pelos meios legais. ${ }^{285}$

Os jovens do tráfico são cientes de que a meritocracia é uma farsa e de que nunca conseguirão atingir suas metas de consumo por meios lícitos. São imbuídos pela sensação de privação relativa, de que não têm nada a perder, consideram "otário" quem vive de "salário mínimo escravo" e preferem viver como reis, embora cativos no morro e com a perspectiva de que morrerão jovens. Já para os trabalhadores, o trabalho, ainda que mal remunerado, lhes confere uma dignidade e superioridade moral de provedores. ${ }^{286}$ Entre o trabalho incessante que os consome lentamente e o crime que destrói rapidamente, escolhem o mal menor. Procuram a liberdade na revolta coletiva, como em eventuais saques, na amizade e no lazer, quando este não é criminalizado. ${ }^{287}$

$\mathrm{Na}$ sociedade pós-moderna os freios sociais representados pela família e a religião perdem força. O indivíduo não está mais tão disposto a fazer sacrifícios em nome do coletivo e suas aspirações de realização pessoal se elevam, diminuindo o aspecto "controle" que, conjugado com o aspecto "motivação", propiciam a criminalidade. ${ }^{288}$ Diante do contexto sócio-econômico e cultural em que vivem estes jovens, talvez o aspecto controle ainda explique o que impede alguns de entrar no tráfico. As leis de imitação de Tarde não explicam a razão pela qual, em iguais condições, uma pessoa cede à influência do modelo desviante com o qual convive, e outra, nas mesmas circunstâncias, não. ${ }^{289}$

Muitos dos jovens traficantes compartilham com jovens "otários" e MCs histórias de vida. Alguns são amigos de infância que seguiram caminhos opostos. As identidades são fluidas e nem sempre é fácil distinguir o informal, o marginal e o ilegal, principalmente

\footnotetext{
${ }^{285}$ MINAYO, Maria Cecília de Souza et alii, op. cit. p. 144. Cf. SHECAIRA, Sérgio Salomão, op. cit. p. 244; BATISTA, Vera Malaguti; BATISTA, Carlos Bruce; BORGES, Rafael C., op. cit. p.10.

${ }^{286}$ Cf. ZALUAR, Alba, op. cit. p. 145-146, 160. Cf. BATISTA, Vera Malaguti; BATISTA, Carlos Bruce; BORGES, Rafael C., op. cit. p. 13, 19.

${ }^{287}$ ZALUAR, Alba, op. cit. p. 160. Bandidos e malandros têm em comum o horror ao trabalho, mas se no imaginário popular o malandro é aquele herói idealizado que repele o "batente", a disciplina do trabalho, as obrigações familiares e sobrevive por ter como armas a malícia, a lábia e a habilidade, o bandido é aquele que optou pelo tráfico ou assalto como meio de vida e possui uma arma de fogo, fonte de seu poder e desgraça ao mesmo tempo (ZALUAR, Alba, op. cit. p. 149-150).

${ }^{288}$ YOUNG, Jock, op. cit. p. 25 et seq.

${ }^{289}$ SHECAIRA, Sérgio Salomão, op. cit. p. 211. Cf. VENTURA, Zuenir, op. cit. p. 178. Um mesmo ambiente social, por exemplo, deu origem, em Vigário Geral, ao sociólogo Caio Ferraz e ao traficante Flávio Negão, amigos de infância. A relação mantida entre os dois era delicada, difícil de ser entendida por quem não fosse de lá. De alguma maneira, os dois representavam a convivência de dois poderes distintos, o intelectual e o militar, e o acordo tácito de poderes garantia espaço para os dois. A utopia de Caio não era derrubar o chefe do tráfico, mas fazer com que em um futuro próximo houvesse mais sociólogos do que traficantes na comunidade (Ibid. p. 168-169, 180).
} 
quando eles vivem próximos. ${ }^{290}$ Alguns MCs, seja antes, seja depois do sucesso, se envolveram ou tiveram parentes e amigos envolvidos na criminalidade, possuindo intimidade com este mundo. Outros foram executados por criminosos e policiais. ${ }^{291}$ Traficantes e MCs compartilham algumas características, o que pode gerar uma identidade entre eles, facilitar uma aproximação simbólica e contaminar todos com o mesmo estigma da marginalidade. Ambos se julgam representantes de suas comunidades, onde nasceram e cresceram, são fiéis a certos preceitos morais, valorizam o ethos da masculinidade e o domínio territorial, possuem fama de conquistadores, procriadores e uma forte relação com os santos ou com os orixás. ${ }^{292}$

Assim como jogadores de futebol, os MCs buscam um caminho rápido e alternativo à rotina estafante do trabalhador "otário" para ganhar dinheiro e prestígio junto às mulheres. Porém, da mesma forma como a vida dos traficantes é curta, a carreira de um MC é efêmera. Neste ponto, mais do que aproximar os jovens do tráfico, o funk pode representar uma alternativa a ele e o fechamento dos bailes, por sua vez, acarretar no aumento da criminalidade por muita gente perder o seu ganha pão. Vários funkeiros afirmaram que por causa do funk abandonaram o tráfico e voltaram à escola, já que "a galera tira sarro de MC analfabeto". ${ }^{293}$ De uma forma muito parecida com a dos traficantes,

\footnotetext{
290 "A facilidade proporcionada pelo espaço da favela para a produção de "identidades plurais" (...) e para a mudança fluída entre as várias identidades (...) deram aos músicos do funk condições para navegarem entre o 'ser bandido`e e 'ser MCs`, entre o cantar o cotidiano da favela e exaltar as façanhas do comando que domina a comunidade (...) O estudo das letras do 'proibidão` evidencia a complexidade das práticas sociais na favela, e aponta a proximidade dos estilos de vida nesse contexto com a ilegalidade. Essa ilegalidade, por sua vez, caracteriza o espaço social e engendra subjetividades específicas. A convivência com o informal, com o ilegal, com o arbitrário, com o violento, torna-se pré-condição para construção de ‘identidades marginais`. O 'proibidão` é fruto da subjetividade construída nesse contexto, por sujeitos que transitam entre os mundos da legalidade e da ilegalidade, do asfalto e do morro, do 'funk normal e do 'funk proibido" (GUEDES, Maurício da Silva. A música que toca é nós que manda: um estudo do proibidão. 2007. Dissertação (Mestrado)-Departamento de Psicologia, Pontifícia Universidade Católica, Rio de Janeiro, 2007. p. 93-94).

${ }^{291}$ Cf. ESSINGER, Silvio, op. cit. p. 106, 144, 146, 160-161, 208, 226; MACEDO, Suzana. DJ Marlboro na terra do funk- Bailes, bondes, galeras e MCs. Rio de Janeiro: Dantes Livraria e Editora, 2003. p. 24, 105; BATISTA, Vera Malaguti; BATISTA, Carlos Bruce; BORGES, Rafael C., op. cit. p. 20-22. É importante, porém, sob o risco de estigmatizar o funk, levar em consideração que diversos outros artistas, de diversos gêneros musicais distintos, já estiveram, de alguma forma, envolvidos com comportamentos rotulados como criminosos, tais como tráfico e porte de drogas, desacato, lesão corporal, vadiagem e até homicídio.

292 RUSSANO, Rodrigo. "Bota o fuzil pra cantar": o funk proibido no Rio de Janeiro. $2006.124 \mathrm{f}$. Dissertação (Mestrado)- Centro de Letras e Artes, UNIRIO, Rio de Janeiro, 2006. p. 22-23, 37 et seq. Sobre a representações do banditismo romântico na figura dos MCs, cf. Ibid. p. 50 et seq. Um aspecto importante da chefia comunitária é, sem dúvida, a virilidade ou, ao menos, a coragem e conquistas amorosas. À semelhança dos traficantes, os líderes comunitários são grandes reprodutores (ALVITO, Marcos, op. cit. p. 143 et seq.). Rômulo Costa, dono da equipe de som Furacão 2000, é conhecido como "pai”.

${ }^{293}$ HERSCHMANN, Micael, op. cit. p. 170, 255-256. Cf. BATISTA, Vera Malaguti; BATISTA, Carlos Bruce; BORGES, Rafael C., op. cit. p. 20, 22. Sobre a efemeridade da carreira de MC, cf. DAYRELL, Juarez. A música entra em cena: o rap e o funk na socialização da juventude. Belo Horizonte: Editora UFMG, 2005. p. 149 et seq. SALLES, Lúcia (Org.). DJ Marlboro: o funk no Brasil - por ele mesmo. Rio de
} 
os MCs de sucesso permanecem na favela, equipando suas casas com milhares de equipamentos de som, televisão etc. ${ }^{294}$

\subsection{Retrato da realidade ou apologia?}

Talvez o pretexto mais forte utilizado para se proibir os bailes de comunidade sejam os chamados "proibidões", funks cantados pelos MCs, cujas letras supostamente fazem apologia ao crime, narrando histórias em que os traficantes justiceiros impuseram seu poder contra os oponentes e fizeram valer a sua lei. Primeiramente, é preciso diferenciar o gênero "proibidão" ou "raps de contexto" de outros gêneros de funk ou gêneros musicais com os quais, por má fé ou ignorância, é confundido. ${ }^{295}$

As letras dos raps, vertente musical do movimento hip hop, são encaradas pelos MCs como armas contra a sociedade, na medida em que retratam sem pudores nem verniz pacificador a dura realidade das favelas e periferias, abordando assuntos como miséria, exploração social, exclusão, racismo, rivalidades de bairro e território, prisão, tráfico, criminalidade, desemprego e violência policial. ${ }^{296}$

Esta postura combativa e muitas vezes agressiva do hip hop acaba por chocar aqueles que ainda crêem no mito do homem cordial brasileiro e da democracia racial. A abordagem nua e crua da temática da violência e as críticas à polícia são confundidas com apologia ao crime. As fronteiras entre retratar a realidade e fazer apologia do crime ficaram, entretanto, ainda mais tênues com a ascensão do gênero gangsta rap, no qual os MCs, muitos deles ex-membros de gangues, ex-traficantes e com históricos de prisões,

Janeiro: Mauad, 1996. p. 44-45. Sobre o mercado de trabalho gerado pelo funk, cf. SOUTO, Jane. Os outros lados do funk carioca. In: VIANNA, Hermano (Org.). Galeras cariocas: territórios de conflitos e encontros culturais. Rio de Janeiro: Editora da UFRJ, 1997.

${ }^{294}$ DEBATE 7, op. cit. p. 355.

295 O primeiro funk "proibidão" que chamou a atenção do grande público, em 1999, foi o "Rap do Comando Vermelho" (ESSINGER, Silvio, op. cit. p. 229). Sobre a origem, as especificidades do gênero e o significado do termo "proibidão", cf. RUSSANO, Rodrigo, op. cit. p. 10-12, 24; VIEIRA, Thiago Fraga, op. cit. p. 77-78 e GUEDES, Maurício da Silva, op. cit. p. 66 et seq.

${ }^{296}$ CARMO, Paulo Sérgio do, op. cit. p. 175, 179, 182, 186. O rap foi adotado pelos jovens negros e latinos dos Estados Unudos, que se reuniam nos bairros ou em alguma saída do metrô, como opção lúdica para conversar e competir em combates simbólicos mediante hábeis discursos verbais e gestuais. Os elementos gestuais, o vestuário, a pobreza e a cor da pele tornaram-se marcas de adscrição grupal, formando novos elementos de identificação, ameaçadores para as classes média e alta, como sucedeu com a expressão funk. Sobre a origem do rap e sua disseminação pelos guetos e periferias do mundo, cf. ARCE, José Manuel Valenzuela. Vida de barro duro: cultura popular juvenil e grafite. Rio de Janeiro: Editora UFRJ, 1999. p. 9091. 
recitam letras quilométricas em que narram em primeira pessoa, com palavrões e gírias de gangues, o cotidiano de criminosos e destilam seu ódio contra a polícia. ${ }^{297}$

O gangsta rap, nos Estados Unidos, assim como o funk carioca, no Brasil, caminha sobre uma corda bamba, no sentido que, se por um lado conserva um quê de marginalidade, raízes no gueto, e é reprimido pelas autoridades, por outro foi absorvido pela indústria cultural. ${ }^{298}$ Os funkeiros, transitando entre a marginalidade dos bailes de comunidade e o mercado, parecem cultivar uma sofisticada capacidade de ambiguidade, justaposição, negociação e ironia, ganhando visibilidade e se apropriando de indumentárias, espaços e ritmos canonizados nas culturas hegemônicas. ${ }^{299}$ Apesar de os rappers mais numerosos pregarem a paz nos guetos e se declararem contra as drogas e armas, a mídia reforça a ideia do rap como algo perigoso, associando-o apenas à vertente gangsta e legitimando sua repressão. ${ }^{300}$

\footnotetext{
${ }^{297}$ O gangsta rap explodiu no final da década de 80 ao falar da crescente deterioração das condições de vida no gueto da era pós-crack. Seu aspecto subcultural fica ainda mais evidente quando se leva em conta a glamorização da violência, das drogas, das armas, do sexo, do consumo de carros de luxo, correntes grossas de ouro e roupas esportivas, os mesmos objetos que conferem status a traficantes e jogadores de basquete provenientes dos guetos negros norte-americanos. Os rappers, aliás, costumam utilizar calças largas, lembrando os uniformes de presidiários, que são folgados devido ao número limitado de tamanhos. Cf. CARMO, Paulo Sérgio do, op. cit. p. 182-184; HERSCHMANN, Micael, op. cit. p. 209; MEDEIROS, Janaína, op. cit. p. 44; ARCE, José Manuel Valenzuela, op. cit. p. 86. As mortes misteriosas dos rappers Tupac e Notorious, que gravavam para empresas rivais, são tributadas à associação de ambos a gangues igualmente rivais. Tupac era da Costa Oeste, onde tinha conexões com membros da gangue Crips, e Notorius da Costa Leste, onde predominam os Bloods (HERSCHMANN, Micael, op. cit. p. 109).

${ }^{298}$ Para a cineasta Denise Garcia, a sociedade não deveria perder tempo com preconceito ou glamorização em torno do "proibidão" e sim deixar que os interesses capitalistas norteiem essa discussão, como ocorreu nos Estados Unidos, onde roqueiros rebeldes e gangsta rappers foram incorporados pelo sistema por meros interesses financeiros, pois, gostando ou não, eles são muito lucrativos (Apud MEDEIROS, Janaína, op. cit. p. 74). Nos EUA, uma onda de protestos liderada pelo líder republicano Bob Dole contra a violência de certas letras de rap levou o grupo Time-Warner a pensar em excluir este tipo de música de sua produção. $\mathrm{O}$ grupo só não tomou essa medida em razão do grande sucesso do gênero musical na indústria fonográfica (HERSCHMANN, Micael, op. cit. p. 122-123).

${ }^{299}$ HERSCHMANN, Micael, op. cit. p. 214-215.

${ }^{300}$ Associações norte-americanas de pais chegou a pedir censura e a exigir o boicote de CDs de gangsta rap. Em carta encaminhada à gravadora do grupo Niggers With Attitude (Negros Com Atitude), na metade dos anos 80, o FBI acusava os rappers de "encorajar a violência e o desrespeito contra o policial". A música que gerou o protesto chamava-se Fuck the Police. Por sua vez, o rapper Ice-T fez sucesso com Cop Killer (Matador de tiras). Censurar ou não esse tipo de manifestação gerou discussões sobre liberdade de expressão e direitos civis, nos Estados Unidos (Cf. CARMO, Paulo Sérgio do, op. cit. p. 182-184; HERSCHMANN, Micael, op. cit. p. 209). Membros do hip hop afirmam que, apesar de vários rappers utilizarem as bases musicais de gangsta raps, poucos deles fazem apologia ao crime nas suas músicas. Mesmo que vários tenham passagens pela polícia, quase todos dizem ter encontrado no hip hop alicerces para construir uma vida longe do crime e para advertir outras pessoas a fazerem o mesmo. Vários chegam a dizer que as músicas caracterizadas como gangsta na mídia são, na realidade, trabalhos feitos por uma minoria que busca se firmar no mercado e, no caso brasileiro, por "uns neguinhos que acham que tudo o que os americanos fazem é o máximo" (HERSCHMANN, Micael, op. cit. p. 196-197. Cf. também CUNHA, Olívia M. G. Conversando com Ice-T: violência e criminalização do funk. In: HERSCHMANN, Micael (Org.). Abalando os anos 90: funk e hip-hop - globalização, violência e estilo cultural. Rio de Janeiro: Rocco, 1997. p. 93).
} 
No Brasil, rappers alegam que o problema não é a música, mas quem canta. Roqueiros, como os Titãs, poderiam dizer "polícia para quem precisa de polícia" sem sofrer as mesmas consequências. Da mesma forma, ninguém iria prender artistas "com costas quentes" como Caetano Veloso e Gilberto Gil por cantarem uma música como Haiti. ${ }^{301}$ Os rappers se esquecem, no entanto, que tanto Gilberto Gil quanto integrantes dos Titãs já foram presos por porte de drogas, o que, inclusive, motivou a composição de "Polícia" por Tony Bellotto. Por outro lado, os funkeiros se queixam que o hip hop e o rock recebem tratamento mais leve por parte das autoridades. O refrão de uma das músicas de Mr. Catra, acusada de fazer apologia ao crime, é “Mata! Mata! Mata!”. Entretanto, no final de "The End", gravada pelo The Doors em 1967, Jim Morrison berra "Kill! Kill! Kill!”. Da mesma forma, a música Cop Killer tocou muito nas rádios brasileiras.

A diferença de tratamento causa revolta no $\mathrm{MC}$, que a atribui ao fato de o funk ser "som de preto e favelado". Deve-se, todavia, levar em conta que o hip hop também é "som de preto e favelado", ainda que atinja um público menor do que o funk, que o alcance de uma letra em inglês no Brasil é muito inferior ao de uma letra em português e que nos Estados Unidos Cop Killer foi censurada e rendeu até investigação pelo FBI. ${ }^{302} \mathrm{Mr}$. Catra lembra que não pode cantar "O Isqueiro" em seu show porque pode ir preso, mas que pode cantar no show de seu parceiro Marcelo D2, porque "nego não prende mais ele, porque é arte, porque é um artista agora renomado", porque o público do D2 é de classe A e B e seu público é funkeiro. A seletividade do sistema penal é denunciada pelo MC: funkeiro pego com uma trouxinha de maconha é traficante e o playboy é usuário; ninguém prende

\footnotetext{
${ }^{301}$ Em um show realizado no Vale do Anhangabaú, em 1994, 20 mil jovens compareceram para assistir à apresentação dos grupos MRN (Movimento Ritmo Negro) e Racionais MCs, grupo acusado de incitar a violência no tumulto da Virada Cultural de 2007. Após os shows, os integrantes do grupo MRN Big Richard e Nill foram levados à delegacia em um camburão e enquadrados no artigo 286 do Código Penal, por incitação à violência. Segundo os agentes policiais, algumas passagens da letra de "Homens da lei", de versos como "Que polícia é essa que diz que quer nos proteger e vira grupo de extermínio assim que escurece?", faziam acusações diretas à ação cotidiana dos agentes policiais. Os rappers não só teriam ridicularizado a polícia como incitado a plateia a reagir a qualquer ação policial. Por sua vez, os rappers, que chegaram a responder processo criminal, declararam à mídia que suas músicas e discursos não visavam promover a "desordem social", mas denunciar uma atuação policial violenta e preconceituosa, passível de ser comprovada historicamente e que atinge especialmente o setor pobre e não branco da população brasileira (HERSCHMANN, Micael, op. cit. p. 110-111, 194-195; CUNHA, Olívia M. G. Conversando com Ice-T: violência e criminalização do funk. In: HERSCHMANN, Micael (Org.). Abalando os anos 90: funk e hiphop - globalização, violência e estilo cultural. Rio de Janeiro: Rocco, 1997. p. 110; CARMO, Paulo César do, op. cit. p. 185-186).

${ }^{302}$ Cf. MEDEIROS, Janaína, op. cit. p. 71-72.
} 
manifestante pró-legalização da maconha em passeata do Posto 9, mas mandariam “caveirão" para reprimir passeata no Complexo do Alemão. ${ }^{303}$

Na época da prisão de Marcelo D2 e de sua ex-banda Planet Hemp (Planeta Cânhamo, em inglês) por apologia às drogas, em 1997, eles receberam a solidariedade de diversos artistas da chamada MPB, assim como o rapper MV Bill, quando foi acusado em 2001 de apologia ao crime por causa do clipe de "Soldado do Morro", no qual apareciam crianças armadas e traficantes encapuzados com metralhadoras nas mãos. A polícia o intimou a prestar depoimento na Delegacia de Repressão a Entorpecentes (DRE), no Rio, para explicar as cenas gravadas. Até o ministro da Justiça da época, José Gregori, o defendeu e definiu o clipe como sendo uma "tentativa de documentar uma fatia dos problemas sociais das favelas". 304

Talvez haja realmente uma maior boa vontade em relação ao hip hop, se comparado ao funk, por ser mais respeitado artisticamente pelos críticos musicais, por movimentar bilhões de dólares nos Estados Unidos, por ser geralmente mais politizado e por ter feito, com maior eficiência, mediadores culturais, como próprio Marcelo D2, que foi indicado até ao Grammy Latino, e Gabriel O Pensador, rapper branco e de classe média. Todavia, isso não significa, conforme já foi ilustrado, que os rappers e $b$-boys não sofram muitas vezes um processo de demonização e sejam confundidos propositadamente pela mídia e pelas autoridades públicas com funkeiros desordeiros. ${ }^{305}$

\footnotetext{
${ }^{303}$ Mr. Catra queixa-se que, enquanto no Brasil "querem encarcerá-lo por retratar a sua realidade" e proíbem a execução de seu documentário, na Europa ele é aceito como cultura e seu documentário passa sem cortes em rede nacional (BATISTA, Vera Malaguti; BATISTA, Carlos Bruce; BORGES, Rafael C., op. cit. p. 2022). Eis a letra de "O Isqueiro": "Oh oh oh ,oh oh cadê o isqueiro?/Demorô forma o bonde dos maconheiro!/Que doidera me deu a louca,/Vou abrir a boca e falar do preconceito/Dessa sociedade escrota./Penso em tudo o que faço e do que faço me orgulho,/Confesso pra vocês eu gosto muito de fuma bagulho./Se tu nao gosta tudo bem,é direito seu/Agora não vem discriminar o direito de fumar que é meu/Fumo,fumo mesmo afirmo pra você/Existe há milianos nunca sem ninguém morrer/Como pode fazer mal?/Me deixa feliz/Se eu experimentei foi porque eu sempre quis/Se sou assim não depende disso,/Se eu sou assim eu to de bem comigo/Mas se tu não tá, não experimenta/Não é com a planta que você vai solucionar/Os seus problemas é melhorar o seu astral/Pense nisso amigo caia na real./(...)/Não pense que maconha é algo sobrenatural/Ficar doidão, método de rebeldia né não/Evolução é ter no dia-a-dia o pé no chão/E não seja pamonha!/Não seja alienado tipo playboy da maconha/Aqueles otários que vivem pela planta/Esse tipo de otário não pia na nossa banca/O vício é erro, parceiro!/Nada é bom quando levado ao exagero/É coisas boas assim como templos, igrejas/Ou coisas legalizadas como o cigarro ou a cerveja/Eu gosto de coisa mais natural/Eu fumo maconha mas é normal/(...)".

${ }_{304}$ MEDEIROS, Janaína, op. cit. p. 51.

${ }^{305}$ É muito comum encontrar matérias que enquadrem o funk como um "gênero menor", uma versão mais ingênua, "primitiva" ou subcultural do hip hop, isto é, uma vertente de "musicalidade pobre" e "irresponsável" dentro do universo do hip hop (HERSCHMANN, Micael, op. cit. p. 108 et seq., 123, 208). Por outro lado, muitos rappers, apesar de terem a mesma origem dos funkeiros e um vocabulário muito similar, fazem questão de se distinguirem deles, pois os consideram musicalmente pobres e alienados, na medida em que os MCs do funk, com raras exceções, são mais comerciais e aparentemente se comprometem muito mais com a diversão. Quando fazem críticas sociais, vêm permeadas pelo bom humor e o deboche
} 
O funk consciente, também chamado de "neurótico", se aproxima tematicamente do rap, com letras críticas, dramáticas, engajadas, politizadas, ácidas, muitas vezes agressivas, fazendo uma crônica dura do cotidiano das favelas e expressando reivindicações sociais. Não encontra praticamente espaço na mídia, sendo marginalizado e promovido por relativamente poucos MCs, que sempre cantam as músicas na primeira pessoa, como se já tivessem vivido aquilo. ${ }^{306}$ Sendo as facções criminosas e as guerras travadas entre elas parte desse cotidiano, seria esperado, pois, que fossem tematizadas nessas letras. Há, porém, um limite tênue entre apologia ao crime e crônica da realidade e a origem social e geográfica dos compositores é determinante na interpretação dessas músicas. ${ }^{307}$

Um exemplo de funk consciente, que retrata a corrupção policial, mas que foi acusado de fazer apologia ao crime e proibido de tocar na rádio é "Cachorro". Seu compositor, Betinho, foi executado pela polícia durante uma operação na favela de Acari $^{308}$ :

\section{Cachorro}

- E ai cidadão, e o arrego?

-Qual é, chefia, de novo? Porra, abalô...

- Com esse salário tá brabo né...

- Hã... Que din-din? Então vende um X9 pra mim!

(UH,Tá mandado, o bondão mata queimado)

Se faz de amigo só pra escutar

(HERSCHMANN, Micael, op. cit. p. 163, 183, 198, 203). Até a libertinagem do funk é criticada por alguns rappers, que cobram uma atitude consciente e uma vida sem vícios. Essa cobrança, todavia, não tem evitado que eles também sejam estigmatizados e reprimidos (Ibid. p. 193-194). Cf. também MEDEIROS, Janaína, op. cit. p. 43 et seq.

${ }^{306}$ Cf. ESSINGER, Silvio, op. cit. p. 222 et seq.

${ }^{307} \mathrm{Mr}$. Catra, um dos principais alvos da perseguição ao funk consciente, alega que "ninguém está incitando ninguém. Ninguém vira bandido por causa do funk (...) O que acontece é que as pessoas ainda não se acostumaram a conviver com a realidade dos outros, ta ligado? (...). Funk é uma crônica, tipo um jornal falado, é apenas um relato do dia-a-dia, ta ligado? (...) Todos os movimentos são tratados pelo departamento de cultura e o funk não. O funk é tratado pela Justiça” (MEDEIROS, Janaína, op. cit. pp. 70-71). Relata que a polícia proibiu sua banda, que "falava das drogas e falava do mal que as drogas faziam e falava do movimento hip hop, ta ligado? (...) A gente também tinha uma música que falava também da trajetória de um viciado, tá ligado? (...) O Isqueiro (...) Essa música não é apologia porque eu falo o porquê da parada, ta ligado? (...) Eu não to falando para o cara fumar maconha. E não pensa que vai resolver seus problemas não, eu falo para ele o que acontece, ta ligado?” (BATISTA, Vera Malaguti; BATISTA, Carlos Bruce; BORGES, Rafael C., op. cit. p. 15-16).

${ }^{308}$ ESSINGER, Silvio, op. cit. p. 160-161. Essa execução é narrada tanto pelo DJ Marlboro (MACEDO, Suzana, op. cit. p. 105) quanto por Mr. Catra, que ainda afirma que Betinho vivia do rap e nunca se envolveu com o crime (BATISTA, Vera Malaguti; BATISTA, Carlos Bruce; BORGES, Rafael C., op. cit. p. 20-22). 
Sujeito safado tem que apanhar

Por causa dele o meu mano morreu

O plantão do trabalho ele enfraqueceu

E causou muita morte, deixando infeliz

A família do mano que eram raiz

Os moradores já querem pegar

Até grampearam o seu celular

O patrão já tá preso e mandou avisar

Que sua sentença vamos executar

É com bala de AK

Cachorro, se quer ganhar um din-din

Vende o X9 pra mim, vende o X9 pra mim

Cachorro, me entrega esse canalha

Deixa ele bem amarrado, pega o dinheiro e rala

$\mathrm{AH}$, sujeito safado já sabe de cor

O endereço, o contato lá do DPO

Comédia fudido que entrega o irmão

Se pego esse verme não tenho perdão

Pago quanto for mas me dá o canalha

Eu vou comer esse verme na bala

De qualquer forma não vai escapar

Eu tenho pra ele uma bolsa de AK

(...)

Outro exemplo de funk consciente, acusado de ser "proibidão", é o Rap das Armas, citado no capítulo 1, que seus compositores, MCs Junior \& Leonardo, tivessem que depor em inquérito aberto pela Divisão de Proteção à Criança e ao Adolescente (DPCA):

Rap das Armas

O meu Brasil é um país tropical

A terra do funk, a terra do carnaval 
o meu Rio de Janeiro é um cartão postal

Mas eu vou falar de um problema nacional

(...)

paparapaparapapara clak bumm

(...)

Metralhadora AR-15 e muito oitão

A Intratek com disposição

Vem a super 12 de repetição

45 que um pistolão

FMK3, m-16

A pistola UZI, eu vou dizer para vocês

Que tem 765, 762, e o fuzil da de 2 em 2

(...)

Nesse país todo mundo sabe falar

Que favela é perigosa, lugar ruim de se morar

é muito criticada por toda a sociedade

Mas existe violência em todo canto da cidade

Por falta de ensino falta de informação

pessoas compram armas cartuchos de munição

mas se metendo em qualquer briga ou em qualquer confusão se

sentindo protegidas com a arma na mão

(...)

Vem pistola Glock, a HK

Vem a intratek Granada pra detonar

Vem a caça-andróide e a famosa escopeta

Vem a pistola Magnum, a Uru e a Beretta

Colt 45, um tiro só arrebenta

E um fuzil automático com um pente de 90

Estamos com um problema que é a realidade

E é por isso que eu peço paz, justiça e liberdade

(...)

Eu sou o MC Júnior, eu sou MC Leonardo

Voltaremos com certeza pra deixar outro recado 
Para todas as galeras que acabaram de escutar

Diga não a violência e deixe a paz reinar.

(...)

Defensores desta vertente de funk sustentam que não é a descrição da realidade feia que deve ser combatida, mas a realidade em si que deve ser mudada. O "proibidão" incomoda porque joga na cara da sociedade uma realidade que ela prefere esconder. Além disso, o funk é um gênero muito popular. Portanto, sua mensagem tem muita força, muito mais do que, por exemplo, o hip hop, e pode influenciar muito mais gente. ${ }^{309}$ Há quem defenda até que o "proibidão" tem uma função pedagógica, no sentido de servir de alerta para a juventude se afastar das drogas e do crime e que é preciso perceber a ironia, pois "cada um entende o que quer". 310

Maurício da Silva Guedes critica, entretanto, o discurso de vitimização dos MCs, que se acentua como "um álibi diante de qualquer tentativa de imputabilidade sobre a sua produção musical”. Critica também a dificuldade dos pesquisadores de "colocar o dedo na ferida" do funk e assinalar seus "aspectos de ilegalidade", na tentativa de "elaborar um discurso em defesa do lazer, da festa e da confraternização que os jovens pobres encontram

${ }^{309}$ MACEDO, Suzana, op. cit. p. 107. Cf. também MEDEIROS, Janaína, op. cit. p. 119; RIBEIRO, Manoel, op. cit. p. 291. Para o DJ Marlboro, "o funk é a trilha sonora de tudo que acontece no Rio", de bom ou de mau, e fala do traficante com a visão de quem está na favela, como um benfeitor, que não entra no barraco do morador com pé na porta, dando tiro, nem mata seu amigo de infância. O DJ não toca nem apoia as músicas de apologia, pois "a gente já vive num clima de terror, todo mundo com medo de sair na rua. Se os comandos ainda forem se tornar ídolos através da música...". Mas ele diz não discriminar os garotos que cantam essas músicas, às vezes buscando com elas uma forma de se destacar na multidão de MCs, pois "seria muita hipocrisia querer calá-los". Acredita que os "proibidões" deveriam ser estudados por antropólogos, sociólogos e autoridades, para "tentar mudar o quadro em que essa garotada está vivendo" (ESSINGER, Silvio, op. cit. 238). Vera Malaguti Batista defende que "o funk é uma cultura, é uma resistência e é também uma estratégia de sobrevivência. Uma maneira de trabalhar e de se divertir. E acho que se a gente pegasse isso, não pasteurizando, mas dando voz, seria uma grande solução. Porque a juventude quer se expressar. O funk é a verdade nua e crua dos morros do Rio. Por isso incomoda. Aí 'não pode'. 'Tem que vir pasteurizado ou com um olhar caridoso ou um olhar raivoso. Quando há um olhar colocado no protagonismo, aí 'não pode', segundo as elites. Nilo Batista se surpreende pela falta de compreensão sobre o "proibidão" ainda hoje: "As pessoas que querem criminalizar o proibidão são as mesmas que na Alemanha Nazista queimavam os livros, são as mesmas da Igreja Católica que fizeram o Index Librorum Proibitorum, são as mesmas que condenariam o Henry Miller, são as mesmas que interrogariam Galileu (Galilei). Isso é um obscurantismo fantástico. Isso é uma intolerância. Mas a verdade policial brasileira é essa. Daqui a cem anos esses delegados, juízes e promotores vão ser sacaneados pela opinião pública. Mas, por ora, os sacaneados são os MCs. E a tarefa da advocacia como contra-poder é de se opor a isso" (Apud MEDEIROS, Janaína, op. cit. p. 107-108).

${ }^{310}$ ESSINGER, Silvio, op. cit. p. 238-239, 271; VENTURA, Zuenir, op. cit. p. 60. “[O Rap das Armas] pretendia fazer o movimento oposto, que era falar: Bom, arma tem de montão, são essas, essas, mas meu amigo, violência, não..." O rap das armas tem diversas versões locais, que individualizam as favelas e seu poder de fogo. Foi a partir delas que todo o processo de criminalização se deu (DEBATE 7, op. cit. p. 362). Cf. CUNHA, Olívia M. G. Cinco vezes favela- uma reflexão. In: ALVITO, Marcos; VELHO, Gilberto (Org.). Cidadania e Violência. Rio de Janeiro: UFRJ e FGV, 1996. p. 207. 
no baile". Mesmo considerando a forma exagerada que a impressa tem abordado os episódios associados ao funk, não há como negar, segundo o autor, que algumas letras expressam apologia ao crime e descrevem ações violentas e de terror. ${ }^{311}$

São estes os funks que devem ser considerados "proibidões". Sua produção musical é precária. Sua autoria é desconhecida. Tocam apenas nos bailes de comunidade, onde são gravados ao vivo, mas podem ser gravados com alguns requintes de estúdio, como a inclusão do som de rajadas de balas, reais ou não. ${ }^{312}$ Os CDs circulam em versões piratas pela internet, são vendidos nos camelôs do Rio de Janeiro e nos bailes, distribuídos como presentes aos clientes das bocas de fumo para divulgar os "produtos" e apontados como um indício de que tais bailes são patrocinados por traficantes. No baile de comunidade, o "cliente" compra, consome e se diverte em um só evento. ${ }^{313}$

\section{Rap do Comando Vermelho}

Bota a cara pra morrer! Tô te vendo, rapá, num adianta

Vermelhooooo

Alemão, tu passa mal porque o Comando é vermelho

Vemelho ô ô ô

É um bonde só de cria que só tem destruidor

Vermelho ô ô ô

O comando é Comando e quem comanda é o Comando

\footnotetext{
${ }^{311}$ Os pesquisadores geralmente falam da "polissemia que gera diversos estilos e identidades ao ser funkeiro, porém, a descrição dos aspectos festivos e lúdicos sobressai aos demais. Quando abordam a violência no contexto das favelas, tratam-na de forma unilateral, representada pelo poder policial ou pela ineficiência das políticas públicas" (GUEDES, Maurício da Silva, op. cit. p. 75-76). Para Guedes, alguns funks não descrevem apenas a realidade, mas servem como "instrumento para a prática criminosa", divulgando as ideias e os objetivos das facções Ao contrário do samba e do carnaval, ambos com origem na favela e proximidade com práticas ilegais, como o "jogo do bicho", o "proibidão" estaria "engajado" com a criminalidade, desde a produção da música até o financiamento dos MCs, que se declaram membros das facções, e dos bailes (Ibid. p. 91 et seq.). A demonstração do poderio bélico da facção nas letras seria uma estratégia para garantir o controle do morro e a manutenção das bocas-de-fumo (Ibid. p. 81).

${ }^{312}$ ESSINGER, Silvio, op. cit. p. 230. Thiago Braga Vieira assinala que a memória é uma das principais bases para a construção do imaginário social dos favelados e seus pontos de referência "costumam ser de ordem sensorial, por isso, o som de tiros que figura nas músicas é mais do que um mero 'clima', assim como as inúmeras descrições da geografia e da paisagem" (VIEIRA, Thiago Braga, op. cit. p. 61).

${ }^{313}$ ESSINGER, Silvio, op. cit. p. 229, 268; VIEIRA, Thiago Braga, op. cit. p. 9; GUEDES, Maurício da Silva, op. cit. p. 84. No CD de "proibidão" e no baile de comunidade, todavia, não tocam apenas músicas que fazem apologia ao crime, fazem referência às armas, morte, favela, miséria e pedidos de justiça e liberdade. Há funks pornográficos, com letras de duplo sentido; religiosos; românticos; "comédia", com letras escrachadas e non-sense e outros que falam de temas banais e cotidianos, como amizade. Cf. CUNHA, Olívia M. G. Cinco vezes favela- um reflexão. In: ALVITO, Marcos; VELHO, Gilberto (Org.). Cidadania $e$ Violência. Rio de Janeiro: UFRJ e FGV, 1996. p. 208-209.
} 
Vermelho ô ô ô

Esse é o ritmo, se liga sangue bom

Mas pra você formar no bonde tem que ter disposição

Porque de dia e de noite, pode crer, a chapa é quente

É melhor pensar direito se tu quer formar com a gente

$\mathrm{Na}$ onda da madrugada o bonde já ta formado

Bruninho no Pod cinco, na boca seu baseado

Tuquinha no Pod dez com o seu fuzil na mão

O Pato já tá ligado, leva um toque pro Fofão

Eu pra todos vacilões eu só quero te lembrar

Que o Branco é sangue bom, mas se amarra em quebrar

Ele é Amigo dos Amigos, sem cumprir vacilação

Se tiver parada errada, dá um toque no Sapão

E quando os bucha sobe a gente bota pra descer

Tô te vendo, seus otário, bota a cara pra morrer

Eu vou te dá-lhe uma ideia pra tu não ficar de toca

Se você é sangue ruim é melhor ralar da boca

(...)

O Fofão no Baseado, Ticki tá no Pod 03

Dando um rolé no morro, fortalecendo o freguês

E se tu é calça arriada é melhor botar um cinto

Tem ET, tem Biano, Delinho na 25

Pros amigos que se foram para nunca mais voltar

$\mathrm{Na}$ letra do meu rap eu quero relembrar

Eu falo do amigo Reinald, que eu lembro com carinho

Do Jassa, do Geleia, do parceiro Ribeirinho

Toda a comunidade, lembro os sangue bom

Falo do amigo Cato, do parceiro Raposão,

Que morreram na covardia e até hoje eu tô bolado

Por isso, autoridade, solta o preso, delegado

Porque já faz muito tempo que ele esta lá

Por isso chegue até o PT e entregue o alvará

Porque o nosso bonde tá doido pra descer 
Pra invadir o Bangu 3 e soltar logo o PT

(...)

E o amigo Vincio é Vermelho ô ô õ

Parceiro Cote é vermelho, é vermelho

E o Toquinho é Vermelho ô ô ô

E a Veruska é do Comando Vermelho

$(\ldots)$

As acusações frequentemente imputadas a alguns cantores de funk (MCs) de que estariam fazendo apologia ao crime também chegaram ao Tribunal de Justiça do Rio de Janeiro:

\begin{abstract}
0036151-53.2006.8.19.0000 (2006.059.05364) - HABEAS CORPUS
DES. MOTTA MORAES - Julgamento: 07/11/2006 - TERCEIRA CAMARA CRIMINAL

Sem maiores aprofundamentos dúvida não se tem pelo teor da letra da música, que no procedimento original tem a qualificação típica de ser apologética, que seu conteúdo contempla situações e afirmativas que não merecem, por impedimento legal, enfrentamento nesta oportunidade. Sabido é que isto é ressaltado no acórdão atacado sobre a existência de presença de indícios de ser a música usada, no caso a de autoria do paciente, como de propaganda de atividade criminosa. Em certos trechos da composição vêem-se referências que justifica a deflagração do procedimento criminal e, nesta instância, o indeferimento do pleito formulado na inicial deste writ.
\end{abstract}

0037366-64.2006.8.19.0000 (2006.059.03837) - HABEAS CORPUS

DES. ALEXANDRE H. VARELLA - Julgamento: 01/08/2006 - SETIMA CAMARA CRIMINAL

A autoridade coatora esclareceu que a prisão preventiva foi decretada pela gravidade do delito, equiparados a crime hediondo, tendo sido acolhidos os argumentos ministeriais, visando a garantia da ordem pública, por conveniência da instrução criminal e aplicação da lei penal (...) Segundo informações prestadas pela autoridade dita coatora, o paciente, vulgo "Colibri" ou "MC Colibri", foi denunciado por contribuir para incentivar e difundir o uso indevido de substância (sic) entorpecentes, se valendo de suas músicas para enaltecer a facção criminosa conhecida por Terceiro Comando Puro (TCP), alardeando sua superioridade em relação as (sic) demais. Quanto à manutenção da prisão do paciente, esta é imprescindível, pois, como esclareceu o douto magistrado foram acolhidos os argumentos da ilustre Promotora de Justiça, a qual fundamentou que a medida tinha: "o propósito de fazer cessar a conduta nefasta do denunciado, traduzida em uma cantoria que, a par de chula, parece ter o único propósito de levar os seus ouvintes a crer na superioridade de determinada facção criminosa, organização essa cuja grande finalidade é destruir, via consumo de substância entorpecente, a vida e a felicidade de cidadãos e de suas respectivas famílias. Segregado o denunciado, estará a sociedade ganhando novo fôlego na sua árdua caminhada de ver-se livre de um dos grandes flagelos dos dias de hoje que é consumo desenfreado de substâncias que determinam dependência". 
0039328-59.2005.8.19.0000 (2005.059.05561) - HABEAS CORPUS

DES. MARCUS QUARESMA FERRAZ - Julgamento: 29/11/2005 SEGUNDA CAMARA CRIMINAL

Trata-se de Hábeas Corpus impetrado pelos ilustres advogados Fernando Augusto Henriques Fernandes, OAB/RJ no 108.329, e outros, com base no artigo $5^{\circ}$, inciso LXVIII, da Constituição Federal, e artigo 647 e seguintes do Código de Processo Penal, em favor de Frank Baptista Ramos, apontando como autoridade coatora a douta Promotoria de Justiça da $1^{\text {a }}$ Central de Inquéritos, alegando, em síntese, o seguinte: a) a $\operatorname{Dr}^{\mathrm{a}}$ Promotora de Justiça requisitou à Delegacia Especializada de Repressão de Crimes de Informática a instauração de inquérito para apuração do crime do artigo 287 do Código Penal, porém, ao invés de cumprir o artigo 69 da Lei 9.099/95, a Dra ${ }^{a}$ Delegada instaurou-o pelo crime do artigo $12, \S 2^{\circ}$, inciso III, da Lei $\mathrm{n}^{\circ} 6.368 / 76$, o que coloca em risco a liberdade e a intimidade do paciente; b) a autoridade policial está indiciando todos os músicos de funk da cidade do Rio de Janeiro; c) pelo mesmo fato está em curso na Delegacia de Roubos e Furtos de Automóveis outro inquérito em que o paciente está indiciado como incurso no artigo 287 do Código Penal; d) não há indícios mínimos do crime da Lei de Tóxicos ou do artigo 287 do Código Penal, tendo em vista que o paciente apenas retrata a realidade dos bairros excluídos (...) [O Dr. Promotor de Justiça Fernando Luiz de Azevedo Costa] aduz, outrossim, que "o expediente inquisitório dá conta da ocorrência de fatos gravíssimos, consistentes em disponibilização por via informatizada de músicas funk, cujas letras não só atentam contra a moral e os bons costumes, mas constituem ilícitos penais cuja apuração é dever do Estado", reportando-se, ainda, às informações prestadas pela autoridade policial (...) Prosseguindo nas informações prestadas ao Juízo da $38^{\mathrm{a}}$ Vara Criminal, aquela Delegada esclareceu que, "Em que pese as dificuldades impostas para a identificação de usuários de Internet que disponibilizam os arquivos criminosos através dos mencionados aplicativos, restava a possibilidade de tentar identificar os responsáveis pela gravação das citadas "canções", ou seja, os donos daquelas vozes que traziam mensagens malévolas... Em novas ondas virtuais, foram localizados, além de inúmeros outros arquivos "cabeludos" de áudio funk proibidão, alguns arquivos de vídeo, com o mesmo conteúdo, que facilitariam a futura identificação." E, assim, constatou aquela autoridade que a grande maioria dos arquivos é conhecida como "funk proibidão" ou "funk do mal", em razão de suas letras enaltecerem traficantes de entorpecentes e líderes de organizações criminosas dedicadas ao tráfico, o que determinou a revisão da capitulação inaugural. No curso das investigações, o paciente foi identificado como intérprete de várias canções de apologia ao tráfico e incentivo ao uso de drogas, sendo, em consequência, indiciado no tipo do artigo $12, \S 2^{\circ}$, inciso III (ou I), da Lei $\mathrm{n}^{\circ}$ 6.368/76, sublinhando a autoridade policial que "Em show realizados (sic) para milhares de pessoas, inclusive fora de "comunidade de favela", em casas de espetáculos famosas e boates na Zona Sul, o paciente incita o público como teor destas canções proibidas, estimulando o consumo e 'glamourizando o tráfico'. Foram anexadas a estes autos algumas letras que, à primeira vista, incentivam o consumo de substâncias entorpecentes, enaltecem traficantes vivos ou mortos e suas organizações criminosas. Em conclusão, absurda se apresenta a pretensão deduzida pelos impetrantes, considerando que há sérios indícios da existência do crime e de ser o paciente um dos autores, devendo as investigações prosseguir regularmente. No que tange ao argumento dos impetrantes que outro inquérito instaurado na Delegacia de Roubos e Furtos de Automóveis se refere aos mesmos fatos, o mesmo não procede, tendo em vista que este procedimento visa tão somente apurar a responsabilidade do paciente em relação a canção "Bonde do Chatuba 157”, que, em tese, faz apologia ao roubo em série de veículos. Por todo o exposto, inexistindo as ilegalidades indicadas na inicial, voto no sentido de denegar a ordem. 


\subsection{Por que os MCs cantam “proibidões"?}

Sem significar necessariamente adesão ao "mundo do crime" ou vinculação a uma determinada facção criminosa, alguns MCs admitem que fazem versões "proibidonas" de sucessos a pedido dos traficantes, seja porque são receosos em se indispor com quem manda na área, seja porque querem agradá-los para conseguir alguma vantagem, seja porque atendem simplesmente o pedido de um velho amigo. Boa parte dos cantores continua vivendo na "comunidade" e é conveniente manter uma política de boa vizinhança com o "contexto".

Outros MCs parecem compor "proibidões" simplesmente porque os jovens da comunidade gostam desse tipo de música, outros por exibicionismo, "criancice", rebeldia, "farra", culto à violência, pelo "gostinho do proibido" ou porque a associação com a marginalidade confere status dentro daquela subcultura juvenil. ${ }^{314}$ Conforme analisado, um dos elementos centrais da subcultura delinquente é a polaridade negativa dos valores. Adotam-se os valores da sociedade, mas com os sinais invertidos, de maneira que muitos jovens que cantam "proibidões", ao contrário do que gostam de aparentar, não têm nenhuma relação com o tráfico de drogas. Apenas sentem prazer em questionar os valores da sociedade, chocando-a. Embora a quase totalidade dos membros das galeras seja de estudantes e trabalhadores, esses jovens tentam escapar da marca de "otário". 315

\footnotetext{
${ }^{314}$ HERSCHMANN, Micael, op. cit. p. 169-170. Depoimentos como o do MC William, detido pela Polícia e acusado, ao lado de seu parceiro Duda, de possuir uma versão do "contexto" do sucesso "Rap do Borel" (regravado, inclusive, pelo cantor Lulu Santos), são bastante sugestivos: "Cantamos, sim, mas foi coisa de criança. Na favela se a gente não demonstra ser esperta, acaba apanhando dos mais velhos. Naquela época tínhamos 16, 17 anos e achávamos maneiro" (Ibid. p. 107). Duda complementa: "a gente mora dentro de uma comunidade. E qual é a comunidade hoje em dia em que não rola um tráfico? (...). Eu moro na comunidade, tenho família lá. E dentro da comunidade tem aquele líder, como em várias comunidades por aí. $\mathrm{O}$ cara escreveu uma letra em cima da nossa letra e perguntou se dava para a gente gravar dentro da nossa comunidade para eles escutarem. E aí gravamos. Não foi uma coisa forçada, foi um pedido. A gente respeitava eles, respeita até hoje. Mas não chegamos a passar a música para fora, cantar em clube. Só que ela foi gravada e se espalhou. E acabou que foi parar na mão da mídia, e eles acharam que o original dela era esse". Segundo Duda, os traficantes passaram a desaconselhar os MCs a cantar as músicas de apologia. "Tem uma guerra entre eles em que a gente não pode se meter". Sobre a acusação de que continuariam a fazer "proibidões", Cidinho dá algumas pistas: "a gente tem que dar sequência na vida. A gente mora numa comunidade que é levada à frente em ritmo de facção. Comando Vermelho ela sempre foi. E a gente não vai poder mudar isso nunca. Mas o funk não tem nada a ver com isso" (ESSINGER, Silvio, op. cit. p. 237-238). A criminalização do funk é facilitada não só porque funk e tráfico dividem o mesmo espaço e histórico social, mas justamente por causa dessa política de boa vizinhança que existe em qualquer gueto ou periferia do mundo e constitui a lei da sobrevivência (MEDEIROS, Janaína, op. cit. p. 11).

${ }^{315}$ ZALUAR, Alba, op. cit. p. 47-48. Segundo um líder de galera, a "rapaziada acha graça em dizer que está com o CV ou o TC, mas a maioria é trabalhador mesmo". A principal motivação deles no baile é "se divertir com seu alemão", gozar e bater na turma rival que mora numa área frequentemente localizada próxima à sua (HERSCHMANN, Micael, op. cit. p. 136).
} 
O delegado Orlando Zaconne afirma que, se a segurança não é apenas um fenômeno objetivo e mensurável, mas complicada por fatores como o preconceito racial e social, então a música pode, de fato, interferir no nível de segurança ou insegurança. No momento em que um "proibidão" é executado na Zona Sul do Rio de Janeiro, expõe-se uma realidade contrastante com a do habitante do "asfalto", criando o medo. Essa capacidade de gerar a sensação de medo é usada pelo jovem favelado que frequenta o baile como um instrumento de visibilidade social. Se no século XIX, o negro usava uma "máscara cômica" para se representar nos lundus e sua presença era tolerada graças à sua representação como bobo e engraçado, agora, no contexto das grandes cidades em que o problema da violência assumiu novas proporções, o negro morador de favelas faz-se visível por uma representação de perigo e maldade, uma máscara aterrorizadora. ${ }^{316}$

MCs alegam que, até em razão da proibição dos bailes de clube, o "proibidão" é uma música que retrata a realidade da comunidade, feita pela comunidade e para a comunidade, ou seja, não contavam com a hipótese de a música vazar, chocar quem não vive aquela realidade e ensejar a repressão. ${ }^{317}$ A mídia, ao fazer as denúncias da venda ilegal dos CDs de "proibidão" e disseminar o medo, paradoxalmente ajudou a popularizar na cidade toda o que até então era popular apenas nas favelas, pois o gênero exalta valores que dizem respeito à pelo menos uma parte de seus moradores. ${ }^{318}$ A aproximação do mundo do crime, que antes diferenciava traficantes e trabalhadores, bem como a captura do momento da performance no baile, causaram fascínio nos jovens de classe média e alta, que passaram a se aliar "filosoficamente" às facções criminosas, a ouvir cantores de "proibidão" em boates de preços proibitivos aos jovens de classe baixa e a tocar dentro de seus carros de luxo, paradoxalmente, funks que "ensinam" a prática do assalto a esses bens. $^{319}$

Jogos de videogame e computador de enorme sucesso entre jovens de todas as classes sociais, como o GTA e o Counter Strike, retratam o mundo da criminalidade e do

\footnotetext{
${ }^{316}$ Apud RUSSANO, Rodrigo, op. cit. p. 25-27.

${ }^{317}$ BATISTA, Vera Malaguti; BATISTA, Carlos Bruce; BORGES, Rafael C., op. cit., p. 16-17; ESSINGER, Silvio, op. cit. p. 235; MEDEIROS, Janaína, op. cit. p. 68-69. Essa diversidade de pedaços e de públicos faz também com que conhecidos cantores de "proibidões" cantem somente a versão "família" de seus sucessos nos programas de televisão ou nas baladas da classe média e alta. No máximo, são cantados os "proibidões" de vertente pornográfica. Para Guedes, entretanto, os responsáveis pela produção do "proibidão" parecem ter consciência da prática ilícita, sabem muito bem que a mensagem dessa produção musical se propagará para além dos limites das favelas, conhecem o poder que a mídia possui e o utilizam o quanto podem para conquistar visibilidade a qualquer preço (GUEDES, Maurício da Silva, op. cit. p. 87-88).

${ }^{318}$ RUSSANO, Rodrigo, op. cit. p. 12, 18.

${ }^{319}$ Ibid. p. 30, 107.
} 
confronto armado usando o "proibidão" como trilha sonora. Esses jogos foram acusados de incentivar a violência, responsabilizados por crimes praticados por adolescentes e houve pedidos para que fossem proibidos, inclusive por parte do campo político que defende a invasão do Iraque e a cultura armamentista norte-americana. Todos os cenários do jogo Counter Strike representam zonas reais de "guerra de baixa intensidade". No caso do Rio de Janeiro, os terroristas são os traficantes do Comando Vermelho e o cenário parodia a favela Santa Marta. Ao adentrar em uma birosca, ouve-se o samba "A semente", interpretado por Bezerra da Silva e acusado de fazer apologia às drogas. Entrando na bocade-fumo, ouve-se o "proibidão". 320

O DJ Marlboro não toca "proibidão" nos seus bailes, mas condena muito mais a classe média que o glamoriza, ao invés de ficar penalizada, do que os meninos de comunidade, que fazem o relato do que vivem por meio da música. ${ }^{321}$ Alguns desses jovens de classe média e alta, porém, se envolvem com essa imagem ameaçadora não só por identificação, mas também por proteção, conforme salienta Maria Rita Kehl:

\begin{abstract}
é mais seguro ser confundido com um "mano" do que com um "playboy" (...). Uma das polarizações que nossa sociedade violenta e competitiva criou não é entre ricos e pobres, brancos e negros: é entre espertos e otários. Claro que para o garoto de classe média posar de "esperto" não garante muita coisa: os enquadres da polícia podem oferecer tanto perigo quanto os eventuais encontros com um assaltante (...). Mas não é só de proteção que se trata. Os adolescentes não estão tentando enganar os bandidos: estão se identificando, de fato, não necessariamente com os criminosos, mas com os marginalizados, os meninos e as meninas da periferia e das favelas (...). O problema é que a cultura da malandragem adolescente é uma resposta à cultura da malandragem que se propaga, de forma mais disfarçada, entre os adultos". 322
\end{abstract}

É possível encontrar uma explicação para essa atração de jovens de classe média pelo "proibidão" também nas teorias que apontam as drogas como "porta de entrada" para a marginalidade e estabelecem uma relação de causalidade entre consumo de drogas e consumo de funk. Tal proximidade seria facilitada pela decadência do prestígio de instituições como a Igreja, a escola e a família. Outra explicação baseia-se na sedução que o crime e a figura do bandido exercem no imaginário popular, diante da ligação histórica entre violência e poder. Oprimidos entre a dominação representada pelas elites e pelo Estado, por um lado, e a nova força representada pelas armas de fogo do narcotráfico, de outro, os “cidadãos de bem" fantasiam no crime uma possível nova fonte de poder.

\footnotetext{
${ }^{320}$ VIEIRA, Thiago Braga, op. cit. p. 66-67.

${ }^{321}$ Apud MEDEIROS, Janaína, op. cit. p. 72.

${ }^{322}$ Ibid. p. 20-21.
} 
Por fim, uma terceira explicação propõe que abraçar o crime, ainda que de forma fantasiosa, está ligado à sensação de atuar em algo proibido, portanto à mesma "adrenalina" dos chamados "esportes radicais". ${ }^{323}$ Uma das características culturais da juventude, e o que a torna um grupo de risco para a violência em todas as sociedades, é o sentido de "aventura", transgressão e afrontamento da lei que a ilegalidade, a clandestinidade, o risco e o uso das armas atiçam. ${ }^{324}$

Não é somente a repressão policial aos bailes de clube que empurra os MCs para os bailes de comunidade, onde o controle do que se faz e do que se canta é muito menor. Deve-se ter em mente que, assim como o mercado formal e lícito de trabalho não absorve toda a parcela de jovens, levando alguns deles a procurar alternativas informais e/ou ilícitas de vida, o mercado, ao fechar suas portas para o funk, obriga alguns MCs a procurar espaços alternativos para fazer shows a fim de garantir a sobrevivência. Rejeitados pela mídia e descartados rapidamente pela indústria cultural, são acolhidos em suas comunidades, onde o gênero "proibidão" faz sucesso. Quem não entra no esquema do "proibidão" muitas vezes acaba deixando de fazer os bailes nas favelas. ${ }^{325}$

Os jovens que frequentam bailes de comunidade e dançam ao som de "proibidões" não nutrem necessariamente simpatia pelo tráfico ou pelo crime em geral. Autores

${ }^{323}$ RUSSANO, Rodrigo, op. cit. p. 28-29. "É certo que a classe média tem seu papel na construção dos mitos sobre o banditismo, mas as representações populares existem e são a raiz, a origem e o ponto de partida de todas as representações formuladas pela classe média" (VIEIRA, Thiago Braga, op. cit. p. 23). "Passei a perguntar informalmente a eles [jovens das camadas médias] o que os seduzia neste universo [bailes], já que as letras das músicas e os códigos e valores não pareciam falar de uma realidade próxima a eles (...) Boa parte respondeu-me que se sentia atraído pela "condição marginal", tanto do funk quanto do hip-hop" (HERSCHMANN, Micael, op. cit. p. 264). Os "proibidões", segundo Ecio P. de Salles, "representam a narrativa de uma realidade particular que, em certo sentido, é perturbadora de uma determinada ética, ou de uma determinada cultura, a que poderíamos denominar hegemônica em mais de um nível. Mas também é uma afronta ao bom-gosto, ou ao bom-senso, não apenas da classe média e das elites, mas de representativos setores do próprio popular", o que pode atrair a atenção da juventude transviada (SALLES, Ecio P de. O bom e o feio: funk proibidão, sociabilidade e a produção do comum. In: Z Ensaios, ano III, no 3, ago/nov 2007. p. 1). Por outro lado, a classe média e alta quando dança o funk quer mais é se divertir e não ouvir a dura realidade dos morros. Após a sua inclusão na trilha sonora do filme "Tropa de Elite", é possível ouvir jovens de classe média e alta paulistana que se identificam com as políticas repressivas de um Capitão Nascimento cantar o "Rap das armas", um funk acusado de fazer apologia ao crime.

${ }^{324}$ MINAYO, Maria Cecília de Souza et alii, op. cit. p. 160-161.

${ }^{325}$ MC Galo confirma que na rádio não consegue divulgação de suas músicas com "letras legais" porque o que toca no programa de um dono de equipe de som não toca no programa de outro. Recusando fazer uma música para cada equipe, o jeito é divulgar as músicas no baile. O problema é que "só dá para participar de bailes nas comunidades que são das facções 'do sangue" (ESSINGER, Silvio, op. cit. p. 238-240). Os bailes comunitários são a porta de entrada no mercado para vários MCs. Muitos garotos da favela gravam uma fita "demo" para mostrar para os DJs, numa tentativa de tocar nos bailes ou na rádio. Eventualmente essa fita pode conter um "proibidão" exaltando o provável contratante, o que constitui uma autêntica peça de venda personalizada (RIBEIRO, Manoel, op. cit. p. 291). O funk fomenta uma economia em torno de si, por meio de soluções feitas dentro da comunidade e para a comunidade, a partir do momento em que do asfalto só vem preconceito, resistência e criminalização de suas manifestações culturais, em detrimento de políticas de apoio sócio-econômicas e culturais. (MEDEIROS, Janaína, op. cit. p. 120). 
apontam para o fenômeno da perda da individualidade dentro da massa que pula freneticamente como se fosse um corpo só. Muitos funkeiros declaram que o que os leva aos bailes é, mais até do que a possibilidade de encontros amorosos, a dança. Nesse contexto, as letras dos funks são coadjuvantes e muitos sequer prestam atenção no que falam. ${ }^{326}$ Por sua vez, há jovens que frequentam bailes de comunidade simplesmente por não terem outra opção barata de lazer ou espaço para encontrar os amigos. Há que se mencionar, por fim, os MCs que parecem compor "proibidões" e jovens que os cantam espontaneamente porque, se não vivem, pelo menos conhecem quem vive aquela realidade descrita e compartilham a imagem do traficante traçada nas letras.

\subsection{O bandido "Robin Hood"}

Analisando algumas das letras de "proibidões", observa-se que o perfil traçado dos criminosos é bastante saudosista, idealizado e romântico. Trata-se de um bandido heróico, extinto ou praticamente extinto, associado ao passado, à realeza negra e às seguintes características, igualmente reivindicadas por alguns MCs, conforme observado acima: é integrado à comunidade pobre onde nasceu e cresceu, é fiel a certos preceitos morais e ao ethos de solidariedade comunitária, é um igual, um representante das pessoas daquele lugar. Possui fama de conquistador, capacidade de gerar um grande número de filhos e uma forte relação com os santos ou com os orixás, o que ajuda na desvinculação com o mal. ${ }^{327} \mathrm{O}$ mesmo traficante que no plano físico impõe a lei por meio dos fuzis se submete à lei divina, buscando, no plano espiritual, o poder na devoção ao "justo". 328

Deus é mencionado constantemente nas letras de "proibidão" como um aliado protetor e há uma justaposição de religiosidade e criminalidade. A exclusão social aparece como motivação para o comportamento criminal ideológico, uma concepção de vida, e não uma infração pontual. A religiosidade legitima esse discurso, pois seus signos

\footnotetext{
${ }^{326}$ Luís França, integrante do grupo Funk Boys, declara: "Quando a gente dança o funk, a música pode ser triste, pode ser alegre, pode ser um protesto, não importa, a gente tá dançando e não quer nem saber o que a música ta passando pra gente, só quer saber que tá dançando, tá se divertindo. Na verdade, a gente quer saber do ritmo, não se interessa pela letra" (SILVA, Suylan Midlej e. O lúdico e o étnico no funk do "Black Bahia". In: SANSONE, Livio; SANTOS, Jocélio Teles dos (Org.). Ritmo em trânsito: sócio-antropologia da música baiana. Salvador: Dynamis Editorial, 1997. p. 211). Sobre a importância de se cantar mesmo o que não se entende, cf. VIANNA, Hermano, op. cit. p. 83. Tati Quebra Barraco observa que, assim como no Brasil o povo se amarra em cantar hip hop mesmo sem entender nada, os alemães cantavam as músicas dela sem saber o que estavam falando (Apud MEDEIROS, Janaína, op. cit. p. 109). O "Rap das armas", de Junior e Leonardo, chegou a tocar bastante em alguns países do exterior.

${ }^{327}$ RUSSANO, Rodrigo, op. cit. p. 22-23, 37 et seq.

${ }^{328}$ Ibid. p. 82-83.
} 
normalmente vistos como positivos, como o combate à hipocrisia, são associados a elementos da criminalidade comumente vistos como negativos. Nessa lógica de "homem bomba", a atitude violenta de "um guerreiro na fúria do conflito" não é contraditória com “a virtude do bom samaritano". A voz que prega a fé em Deus e a união das favelas é a mesma que pede Paz, Justiça e Liberdade, o lema do Comando Vermelho. ${ }^{329}$

É comum, aliás, em "proibidões", a menção a militantes islâmicos da Al-Qaeda. As experiências compartilhadas geram na "ralé" carioca um sentimento de pertencimento que se desenvolve em uma consciência de classe. A "ralé" não identifica o antagonismo entre exploradores e explorados com o uso de categorias marxistas, mas com uma terminologia própria: favelados e bacanas, morro e "asfalto", playboys e sofredores. O sofrimento cotidiano da "ralé" legitima a ação violenta, principalmente, porque aos olhos dela a sociedade pouco se importa com o que a aflige. O sofrimento é o elemento fundamental compartilhado que une os "irmãos sofredores": presos e seus familiares, bandidos, professores, donas de casa, crentes, funkeiros, favelados.

Embora a classe dos sofredores seja composta por diversos setores sociais, o setor "criminal" é o protagonista. O "proibidão" afirma que a solidariedade de classe, pelos “irmãos sofredores”, é a motivação que torna os traficantes guerreiros, e não o dinheiro. Aqueles que não são da fração "crime" desta classe também compartilham essa experiência, pois são vizinhos, amigos e parentes de criminosos. Mesmo que não façam parte diretamente desta realidade, a conhecem por proximidade, pois moram no mesmo "espaço geográfico" e compartilham o mesmo "espaço social".

Todos os guetos e todas as populações oprimidas são entendidos como semelhantes, mesmo que à distância. A vida da "ralé armada carioca" é comparada frequentemente nos "proibidões" com a de grupos guerrilheiros como as FARCs ou de rebeldes jihadistas, pois todos são vistos como guerreiros populares que lutam contra o sistema opressor. São taxados de terroristas, assim como os traficantes são taxados de criminosos. A hipocrisia da intervenção das forças armadas estadunidenses no terceiro mundo, por sua vez, é comparada com a da atuação policial nas favelas. Embora o pretexto alegado para a invasão do Iraque seja a guerra contra o terror e para a ocupação de favelas, a guerra contra a criminalidade, no primeiro caso a guerra é motivada pelo petróleo e no segundo, as

${ }^{329}$ VIEIRA, Thiago Braga, op. cit. p. 5, 58, 62-63. 
incursões visam à arrecadação do "arrego". ${ }^{330}$ Há, portanto, uma identificação entre o cenário de guerra do Afeganistão, Iraque e da Colômbia e as favelas do Rio de Janeiro.

O bandido "formado" segue e impõe regras de conduta para restaurar a ordem após um tempo de terror. Conhece as regras do jogo e não ultrapassa os limites de sua atuação. É rigoroso, mas só faz uso da violência em último caso, é misericordioso, justo, justiceiro, o vingador de seu povo, o pai. Defende a inviolabilidade do território, impede a prática de crimes dentro de seu "pedaço", não só para garantir a segurança dos trabalhadores, mas também para preservar a honra e a dignidade dos moradores daquele local. Pensa no bem da comunidade, respeita os mais velhos, as crianças ${ }^{331}$, os trabalhadores e os defende dos "pivetes", dos criminosos "alemães" e da polícia corrupta e truculenta, vista muitas vezes como composta por bandidos piores do que os traficantes. ${ }^{332}$

${ }^{330}$ VIEIRA, Thiago Braga, op. cit. p. 48 et seq. Os ídolos de Mr. Catra são Salomão, Moisés, Selassiê, Che Guevara, Pablo Escobar e Osama Bin Laden, "todos os caras que lutam contra o imperialismo e a favor da liberdade. Todos os que lutam a favor de sua cultura, de suas raízes" (Apud ESSINGER, Silvio, op. cit. p. 227). Para Guedes, entretanto, as referências a ícones do terrorismo mundial reforçam as pretensões dos traficantes de impor o medo à sociedade (GUDES, Maurício da Silva, op. cit. p. 83, 91). Os trabalhadores desenvolvem "teorias sociológicas" e "teorias psicológicas" para tentar compreender o bandido, muitas vezes complementares e/ou contraditórias. Por um lado, as teorias espelham a necessidade de discriminar os caminhos escolhidos e diferenciar os bandidos moralmente. Muitos trabalhadores consideram que entrar para a criminalidade é um erro, "atraso", "marcação", "condomínio do diabo", "sina", o sinal de uma vingança de entidades espirituais, uma escolha pessoal de quem tem "mente fraca", "é teleguiado dos outros", "é sugestionado", "aprende com os outros garotos já perdidos". Por outro lado, a reflexão sobre as determinações sociais e a constatação de que "é bandido quem não pode pagar pela impunidade" relativiza a oposição entre trabalhadores e bandidos e acaba por aproximá-los enquanto pobres e sofredores, submetidos às mesmas condições de vida: desemprego, racismo, miséria, ausência do pai, impossibilidade de a mãe cuidar, violência policial. A diferença é que o bandido "se revolta" com essas injustiças. Todo mundo sabe que o fim dos bandidos pobres é morrer antes dos 25 anos, o que leva muitos a acreditar que "ninguém é bandido porque quer" (ZALUAR, Alba. A máquina e a revolta: as organizações populares e o significado da pobreza. São Paulo: Editora Brasiliense, 1985. p. 152 et seq.).

331 O apelo do "proibidão" alcança os jovens ainda na infância e instrumentaliza boa parte das brincadeiras infantis. Não é raro ver coros formados por crianças nas gravações de "proibidão". As facções se julgam protetoras das crianças da favela. Além disso, no mundo do crime, como no mundo do funk, ser "de menor" não é desqualificativo, nem resulta em exclusão da participação, muito pelo contrário (VIEIRA, Thiago Braga, op. cit. p. 77-78). Entretanto, personagens como "Jack, o Matador", "Escravos do pó" (em vez de Jó) e outros bandidos tematizados traduzem uma realidade com a qual boa parte da população local não compactua. Ao ritmo de cantigas de roda, estes "proibidões" infantilizam de certa forma o terror existente na favela e falam de meninos obrigados a conviver desde cedo com todo o tipo de violências (HERSCHMANN, Micael, op. cit. p. 169). Sobre as montagens funk-estórias de "Jack, o Matador", um herói justiceiro, paspalhão e "assustador de criança", sampleado dos seriados de faroeste, dos filmes policiais e dos discos infantis, cf. CUNHA, Olívia M. G. Cinco vezes favela- uma reflexão. In: ALVITO, Marcos; VELHO, Gilberto (Org.). Cidadania e Violência. Rio de Janeiro: UFRJ e FGV, 1996. p. 209-210.

${ }^{332}$ CARMO, Paulo Sérgio do, op. cit. p. 219. "Embora tanto o bandido quanto o policial tenham imagens carregadas de ambiguidades, é a polícia que aparece quase sempre caracterizada pela completa ausência de moral (...) $\mathrm{Na}$ visão dos moradores, sempre matou covardemente, pelas costas, sem avisar, por motivos desconhecidos. Ao contrário, o bandido mata para se vingar de alguma traição ou defender sua honra e seu espaço" (ZALUAR, Alba. O condomínio do diabo. Rio de Janeiro: Editora Revan/UFRJ, 1994. p. 19). Os moradores dizem preferir, entre o policial e o bandido, a este último, que conhecem e com quem podem conversar (ZALUAR, Alba. A máquina e a revolta: as organizações populares e o significado da pobreza. São Paulo: Editora Brasiliense, 1985. p. 157). O Estado não é visto como a instituição que garante o direito e 
Por fim, o bandido "formado" não se torna bandido simplesmente pelo desejo de empunhar uma arma para tomar o poder e ter acesso a bens materiais. A entrada para o mundo do crime ocorre por meio de um episódio dramático, geralmente alguma injustiça sofrida por causa de sua condição social, violência policial ou de outros bandidos. Sua morte também se dá de forma trágica e mítica. ${ }^{333}$ Almejando obter o apoio da comunidade, até porque este é necessário para que não seja traído ou delatado, o bandido "Robin Hood" adota práticas assistencialistas e clientelistas, doando alimentos, remédios, roupas, brinquedos e investindo em asfalto, iluminação e lazer para os moradores, como quadras de esporte, piscinas, escolas de samba e, claro, bailes funk. Os garotos que vivem em favelas "têm poucas alternativas além de julgá-lo paradigma de 'um igual bem sucedido', poderoso, respeitado/temido, valente, generoso, com prestígio entre as mulheres etc". ${ }^{334}$

Em um contexto neoliberal, o indivíduo perde suas referências coletivas públicas, como a de direitos de cidadania. Os serviços e instituições públicas são dilapidados e seus usuários estigmatizados. Os indivíduos são empurrados para a lógica do mercado competitivo e desigual, do "cada um por si", e as garantias de viabilização de sua existência são limitadas às possíveis de serem alcançadas por energias e sagacidades próprias ou por solidariedades pessoais e lealdades privadas. Ganham força, assim, os

\footnotetext{
a justiça na resolução de conflitos, mas como fonte de injustiças e conflitos. A repressão penal é seletiva, os bandidos bons pagadores ficam impunes, a polícia cobra o "arrego" e dá suporte à facções inimigas na invasão e na manutenção do território (VIEIRA, Thiago Braga, op. cit. p. 22). Antes do controle territorial exercido pelo Comando Vermelho em algumas favelas, era costumeiro ter a casa invadida e saqueada por policiais sob argumento de que tudo na favela seria produto de roubo (Ibid. p. 25). "A suspeição generalizada e as arbitrariedades policiais contribuem para uma percepção social em que a imposição da ordem pública e a repressão dos comportamentos 'marginais' são vistas como mera hipocrisia, claros instrumentos de dominação. Esta percepção estabelece uma relação de antagonismo aberto e favorece estratégias de resistência que ignoram a legalidade. Mais do que a miséria, o sentimento de que a lei só vale para lhes oprimir é o que parece alimentar a delinquência como um comportamento coletivo" (Ibid. p. 42). Mais do que o crime organizado, a polícia é apontada nos depoimentos e nas narrativas de experiências dos rapazes e moças como o agente principal da violência no Rio de Janeiro e não como um agente protetor. Cf. MINAYO, Maria Cecília de Souza et alii, op. cit. p. 162 et seq.; YÚDICE, George. A funkificação do Rio. In: HERSCHMANN, Michael (Org.). Abalando os anos 90: funk e hip-hop - globalização, violência e estilo cultural. Rio de Janeiro: Rocco, 1997. p. 37.

333 RUSSANO, Rodrigo, op. cit. p. 22-23, 37 et seq. Um bom exemplo de bandido "formado" é Mane Galinha, de Cidade de Deus. Após sua morte, ganhou um samba e várias estórias sobre a sua valentia, beleza e simpatia. Sempre ajudou a família, foi operário, bom filho, bom jogador de futebol, sambista ocasional e diferia de outros bandidos por participar ativamente das atividades locais. Era um injustiçado, um "revoltado" e teve uma morte trágica. Seu enterro foi um acontecimento e a área em que morava ficou conhecida como a "vila do Mané Galinha" (ZALUAR, Alba. A máquina e a revolta: as organizações populares e o significado da pobreza. São Paulo: Editora Brasiliense, 1985. p. 134 et seq.). Já seu rival Zé Pequeno é o representante da nova bandidagem sádica, que impõe o terror pelas armas e violenta as mulheres. São exemplos ainda de "bandidos formados" Tunicão, de Acari (Cf. capítulo 6 de ALVITO, Marcos, op. cit.) e Flávio Negão, de Vigário Geral, uma comunidade vítima da violência policial e da omissão do Estado (VENTURA, Zuenir, op. cit. p. 65-66, 77, 81-82, 108-112, 184-187, 192, 197-200, 206-210, 259, 272-273).

${ }^{334}$ RIBEIRO, Manoel, op. cit. p. 291.
} 
espaços mais privatizados da vida social, como a família e sistemas de autoridades locais que, mesmo ilegais, são próximos e conhecidos. ${ }^{335}$

Não se deve, porém, idealizar um bandido-protetor e concluir que se está diante de um herói romântico ou de um líder de movimento social. Se o traficante desenvolve um papel protetor sobre as suas comunidades é por causa dos laços de vizinhança estabelecidos durante a vida, mas principalmente como estratégia de apoio ao seu negócio, contra as forças de segurança e contra os grupos rivais. Atuam para receber guarida da população, criando uma base de legitimidade e de temor sobre a qual operam. ${ }^{336}$ Sua atividade principal está no rendoso comércio de drogas e seu estilo de vida está longe de ser contestatório. O que atrai nesta opção são a fama, o poder e o dinheiro fácil que ela traz, apesar de serem poucos os que na realidade conseguem isso.

Como consumidores, os bandidos não desenvolvem um estilo próprio de vida em bandos de fora-da-lei, mas almejam os bens que a sociedade de consumo lhes oferece. Não são reformistas, nem revolucionários. Não são contraculturais, mas subculturais. Sua revolta é individual. Às vezes cobram pedágios e taxas de proteção, além de desempenhar funções assistencialistas, mas não gozam da legitimidade do Estado. Alguns reproduzem em suas comunidades as técnicas repressivas aprendidas na sua condição de membro das classes subalternas oprimido pelo Estado. ${ }^{337}$

\footnotetext{
${ }^{335}$ NETO, Ana Maria Q. Fausto; QUIROGA, Consuelo. Juventude urbana pobre: manifestações públicas e leituras sociais. In: PEREIRA, Carlos Alberto Messeder; RONDELLI, Elizabeth; SCHOLLHAMMER, Karl Erik; HERSCHMANN, Micael (Org.). Linguagens da violência. Rio de Janeiro: Rocco, 2000. p. 231. No contexto da visão negativa que o trabalho assalariado tem e na falta de um movimento operário forte de onde saíam líderes trabalhadores com fama, os jovens da favela adotam como modelos os simpáticos malandros de outrora e os bandidos armados de hoje, que provocam sentimentos ambíguos de admiração e medo, pela sua valentia pela força das armas (ZALUAR, Alba. A máquina e a revolta: as organizações populares e o significado da pobreza. São Paulo: Editora Brasiliense, 1985. p. 156). Os moradores da favela estão quase excluídos de vez da participação na sociedade nacional. Constroem então uma identidade própria pertencente ao seu mundo, ao seu lugar. O Estado é grande demais para resolver os pequenos problemas e pequeno demais para resolver os grandes problemas. A lógica romântica e nostálgica da comunidade é, ao mesmo tempo, uma construção ideológica e uma estratégia de vida, dentro da premissa de que "se eu não tiver a solidariedade de meus vizinhos, se eu não tiver alguma expectativa de reciprocidade, eu estou absolutamente ferrado, dentro das condições de vida que são as minhas" (DEBATE 7, op. cit. p. 350-351).

${ }^{336}$ MINAYO, Maria Cecília de Souza et alii, op. cit. p. 160.

${ }^{337}$ ZALUAR, Alba. A máquina e a revolta: as organizações populares e o significado da pobreza. São Paulo: Editora Brasiliense, 1985. p. 165-167. Na relação ambígua entre os traficantes e a comunidade, benevolência e intimidação são os dois lados da mesma moeda e explicam o fato de moradores fazerem escudos humanos para defender os traficantes da polícia, queimarem ônibus quando um deles é preso ou morto e fecharem o comércio em sinal de luto. Usando também a violência e intimidação, os traficantes enfraquecem associações comunitárias e causam a impressão equivocada de que ocupam um papel que caberia na realidade ao Estado ocupar (ESSINGER, Silvio, op. cit. p. 232-234; ARCE, João Manuel Valenzuela, op. cit. p. 96). São apontadas algumas dessas ações "assistencialistas" de Flávio Negão e Robertinho de Lucas em Vigário Geral e Parada de Lucas, respectivamente, em VENTURA, Zuenir, op. cit. p. 83, 107, 202, 209.
} 
Talvez por trás dessa imagem idealizada de bandido esteja o desejo das comunidades de recuperar, ainda que apenas no imaginário coletivo, um tipo de bandido que não existe mais, que ficou no passado, que apresenta as características opostas às dos bandidos que atualmente dominam por meio do terror os morros cariocas e que também são descritos nos "proibidões". Até por causa do assassinato dos principais líderes do tráfico, o bandido atual geralmente é menor de idade, causando uma reviravolta nas relações de poder no interior de uma população antes regidas pela hierarquia entre as gerações. O novo bandido chega ao poder exclusivamente pela força da arma de fogo. Os moradores lamentam a queda da moral e a ascensão do "ferro", da "máquina", um fetiche que os bandidos exibem com orgulho em sua cintura. Entre eles, "ter disposição para matar" é um sinal de coragem, mas entre os trabalhadores é um sinal de covardia.

Em vez de "dar uma ideia”, o bandido novo "sugestiona”, valendo-se de sua arma de fogo, ou seja, intimida e humilha o trabalhador, o que não é bem visto. Ele não possui rosto, uma história a ser contada nem uma forte relação com a comunidade. Por outro lado, a identificação do morador com o local em que mora, um mecanismo importante na formação de sua identidade social, leva-o a fazer diferenciações preconceituosas. O bandido de outras áreas é sanguinário, perverso, covarde ou ladrão, enquanto na área do morador predominam os trabalhadores pacatos e os bandidos "formados".

O bandido atual, "pivete", "bandido porco" ou "bandido sanguinário", não é conhecido por seu nome, é identificado nos veículos midiáticos por abreviaturas, cria um estado de "terror" nas favelas, de ausência de ordem e paz. Entra para o crime pela busca do poder imediato e dinheiro, estupra as mulheres, oprime os trabalhadores, não respeita e não é respeitado pela comunidade. Não segue as regras explícitas de convivência com os moradores, que exigem o respeito e a proteção mútuos, e fere a moral de classe, pois um roubo é condenado ou não segundo quem é roubado. Quando atua sob um conjunto de normas, estas não são, de forma alguma, limitadoras de seu poder. Por fim, não possui nenhuma relação com religião ou com qualquer tipo de devoção. ${ }^{338}$

\footnotetext{
${ }^{338}$ RUSSANO, Rodrigo, op. cit. p. 43 et seq.; ZALUAR, Alba. A máquina e a revolta: as organizações populares e o significado da pobreza. São Paulo: Editora Brasiliense, 1985. p. 140 et seq. "A violência começa a criar o clima de terror e desespero quando este controle desaparece junto com as distinções inocente/culpado, justo/injusto, trabalhador/bandido. Por isso são tão diferentes a reação ao bandido formado que segue as regras, e não ultrapassa os limites de seu poder, e a reação aos pivetes de um lado e à polícia de outro. É que no primeiro caso a violência ainda é controlada e pode ser compreendida dentro da concepção popular de justiça, ao passo que no segundo caso ela não é. O pânico gerado por esta falta de controle da violência e as profundas feridas que causa no senso de justiça do povo geram os linchamentos cada vez mais
} 
O "proibidão", muito mais do que fazer uma apologia ao crime ou ao bandido romântico, faz uma apologia ao "banditismo romântico". 339 A admiração antes direcionada aos antigos "donos" dos morros tem encontrado certo tipo de refúgio nas chamadas facções criminosas. A apologia ao Comando Vermelho e ao Terceiro Comando está na verdade relacionada à busca pela ordem, por um código de regras ou outros valores que não são mais adotados pelos grupos armados dos morros. A facção é usada como um rótulo que confere poder à comunidade e, por conseguinte, a todo aquele que dela faz parte. O poder apoia-se principalmente na força das armas, mas tenta-se também conferir legitimidade às “organizações” e seus integrantes. O bandido, portanto, não é apenas qualquer pessoa portando um fuzil, mas um sujeito que pertence a uma organização cheia de princípios. ${ }^{340}$

Cada favela é dominada por traficantes de uma dessas facções e este domínio gera um vínculo imediato de uma comunidade com outras, dominadas por bandidos da mesma "organização". Esta ligação acaba gerando uma identificação entre os moradores, extrapolando o âmbito da criminalidade e tornando-se uma identidade da favela. Assim, não há necessariamente uma associação real do MC e sua audiência com o crime. O que acontece é mais uma atitude de transgressão. ${ }^{341} \mathrm{O}$ funk se tornou o palco para o confronto de versões sobre a história e as condutas coerentes dos envolvidos na violência armada organizada carioca. O assassinato de uma liderança do tráfico, por exemplo, pode ser cantado em um "proibidão" de sua facção como uma covardia, ou como uma justa vingança, no "proibidão" da facção rival. Nos "proibidões" são descritas não só a história

frequentes" (ZALUAR, Alba. O condomínio do diabo. Rio de Janeiro: Editora Revan/UFRJ, 1994. p. 30-31). São preferíveis, assim, regras muito rígidas do que perda da referência normativa.

${ }^{339} \mathrm{Mr}$. Catra lamenta a cultura individualista que impregnou a favela e a decadência do crime ideológico (BATISTA, Vera Malaguti; BATISTA, Carlos Bruce; BORGES, Rafael C., op. cit. p. 17-18). Esta distinção, no entanto, é carregada de preconceitos. O discurso sobre a extinção do bandido assistencialista romântico é repetido há duas décadas, mas a data da extinção avança sempre que o discurso se repete, o que sugere que a proximidade no tempo é o principal elemento que influencia os observadores a decretarem que o bandido atualmente em atividade não se enquadra no tipo romântico (VIEIRA, Thiago Braga, op. cit. p. 3). Uma abordagem isenta não deve romantizar o bandido do passado como assistencialista nem demonizar o bandido do presente como irracionalmente violento (Ibid. p. 81). São pouquíssimos os bandidos contemporâneos vistos como "sociais" durante sua atuação. É após a morte que seu perfil será revisto com cores românticas. O bandido precisa deixar a vida para adentrar o mito (Ibid. p. 26).

${ }^{340}$ RUSSANO, Rodrigo, op. cit. p. 44 et seq. O próprio lema do Comando Vermelho: "Paz, Justiça e Liberdade" e sua origem mítica aponta para essa questão (Ibid. p. 62).

${ }^{341}$ Ibid, p. 9-10, 85. Na interpretação das músicas ocorre muitas vezes, inclusive, uma transmissão de responsabilidade para o público na hora de cantar o trecho mais agressivo da letra, quando é retratada, por exemplo, uma ação como matar ou quando é dito um palavrão. O cantor afasta o microfone momentaneamente da boca, convocando a plateia a completar o trecho. Essa convocação do público parece gerar cumplicidade entre cantor e espectadores e também um fortalecimento daquele por estes. "Algo como: 'são vocês que estão falando, portanto eu não estou sozinho nessa'. Ou ainda uma representação do 'problema' que é cantar essas partes das letras: o grito da massa (e o anonimato que ela propicia aos seus componentes) seria assim o dispositivo para a resolução da questão" (Ibid. p. 67-68). 
das guerras entre facções, seus rachas, mas também suas alianças, como a que vigorou entre o Terceiro Comando e os Amigos dos Amigos, de um lado, e o Comando Vermelho e o Primeiro Comando da Capital, do outro, entre 1994 e $2002 .^{342}$

Através das letras dos "proibidões", se tem uma ideia de como se encontra a "geografia do tráfico", como os principais comandos estão distribuídos nos morros e favelas da cidade, quem é aliado e quem é inimigo. ${ }^{343}$ Cada MC representa uma facção e defende uma versão da história, logicamente aquela que mais glorifica e fortalece a facção defendida. Os "proibidões" são discursos que lutam contra o silêncio, que questionam a paz, que produzem uma memória acerca da criminalidade. São o instrumento para se ouvir a voz dos setores marginais da nossa sociedade, são "a História vista por baixo", uma memória coletiva subterrânea, clandestina, sufocada, que entra em choque com a memória coletiva oficial, a qual uma sociedade majoritária ou o Estado desejam impor. ${ }^{344}$

Gramsci formula uma concepção dual de Estado, baseado em duas formas de dominação: a hegemonia e o poder coercitivo. A sociedade civil compreende a ideologia da classe dirigente em relação às artes, ao folclore, etc. Sendo assim, artistas de rua seriam instrumentos de difusão da ideologia, atuando como elementos multiplicadores dessa hegemonia existencial. A sociedade política, por sua vez, concentra o aparato jurídicocoercitivo para manter, pela força, a ordem estabelecida. Compreende o exército, a polícia, o aparelho burocrático, as esferas de governo, etc.

A complexidade do Estado moderno faz com que a dominação habitual, em decorrência da hegemonia, seja a usada diuturnamente. Nos momentos de crise orgânica, a classe dirigente perde o controle da sociedade civil e apoia-se na sociedade política para manter sua dominação. Nas sociedades menos diferenciadas, é em torno da sociedade

\footnotetext{
${ }^{342}$ VIEIRA, Thiago Braga, op. cit. p. 74. Sobre a história desses rachas e alianças entre facções, cf. Ibid. p. 40-41. Durante todo o período em que vigorou a aliança entre o TC e ADA (1994-202), a produção de seus "proibidões" foi unificada. Aliás, foi neste período que o "proibidão" de facção surge como uma forma diferenciada de funk. Os MCs, assim, devem ser considerados "formuladores e difusores do discurso relacionado às facções" e fonte de narrativa oral para o entendimento da história do tráfico no Rio de Janeiro, bem como para o conhecimento do imaginário da juventude pobre carioca, o que demonstra a importância do estudo do "proibidão" (Ibid. p. 5 et seq.).

${ }^{343}$ GUEDES, Maurício da Silva, op. cit. p. 89.

${ }^{344} \mathrm{O}$ não reconhecimento de uma memória subterrânea que tenta romper o silêncio por outra imposta em seu lugar "contribui para reforçar a amargura, o ressentimento e o ódio dos dominados, que se exprimem então com os gritos da contraviolência" (VIEIRA, Thiago Braga, op. cit. p. 9, 43-45). "O silêncio e o esquecimento das versões da história oficial são, talvez, mais cruéis do que as armas de fogo na tentativa de sufocar a memória social que origina as formas de atuação pré-política e reativa do lumpem proletariado. Cabe aos historiadores apontar a importância dessas memórias subterrâneas e compreender o papel da marginalidade na sociedade brasileira na segunda metade do século XX, e até quando durar esse estado de coisas" (Ibid. p. $82)$.
} 
política que a luta se concentra. Nas sociedades mais complexas, o essencial do combate ideológico se dá no âmbito da sociedade civil. ${ }^{345} \mathrm{Na}$ tentativa de impor seu domínio, todos os grupos envolvidos na violência armada organizada carioca buscam difundir seu imaginário, seu discurso identitário-normativo mediante o "proibidão". Há, portanto, "proibidões" que exaltam não só as facções criminosas, mas também as milícias e policiais do BOPE, estes ironicamente chamados de "permitidões". 346

\subsection{Crime, literatura, música e cinema}

É interessante notar a recorrência da glamorização e idealização de bandidos e a exaltação de seus feitos em músicas, cordéis e lendas populares. Foucault conta que um dos motivos pelos quais os suplícios públicos de bandidos na Idade Média deixaram de ser praticados foi o fato de causarem efeitos políticos imprevisíveis e contrários aos esperados, gerando muitas vezes junto à população os sentimentos de simpatia pelo criminoso supliciado, e de revolta contra o rei opressor. Depois de mortos, os bandidos mártires ganhavam as páginas de libretos populares e representavam uma ameaça ainda maior, pois, ao invés dessas narrativas legitimarem uma justiça rigorosa e intimidarem a população, elas poderiam glorificar os bandidos e torná-los heróis para as classes populares pela enormidade de seus crimes largamente propalados, pela afirmação de seu arrependimento tardio, por sua irredutibilidade na hora do suplício e por ter travado um combate com os ricos, poderosos, magistrados e policiais.

Essas narrativas de vidas infames foram proibidas e o crime foi reescrito esteticamente, de maneira que a criminalidade foi apropriada sob formas aceitáveis. Nos romances policiais, os belos assassinatos, considerados uma obra de mestre, são cometidos apenas por membros das classes altas, porque o crime se torna privilégio dos que são realmente grandes, porque "revelam a monstruosidade dos fortes e poderosos, porque a perversidade é ainda uma maneira de ser privilegiado". Essas narrativas tornam-se uma espécie de frente de luta em torno do crime, de sua punição e lembrança. Se esses relatos eram lidos com tanta atenção e curiosidade pelas classes populares, é porque elas

\footnotetext{
345 Apud SHECAIRA, Sérgio Salomão, op. cit. p. 58-59.

${ }^{346}$ VIEIRA, Thiago Braga, op. cit. p. 65-66. Como boa parte dos policiais tem a mesma origem social que os integrantes do tráfico, ou seja, os morros e favelas da cidade, é natural que ambos compartilhem da mesma linguagem, do mesmo universo cultural e da mesma preferência musical. Os "permitidões" pregam a morte de traficantes e exaltam os feitos dos policiais (GUEDES, Maurício da Silva, op. cit. p. 90-91).
} 
encontravam na "epopeia menor e cotidiana das ilegalidades" não só lembranças, mas pontos de apoio político. ${ }^{347}$

No século XVIII, surgia uma nova riqueza material consistente em matérias-primas, máquinas e instrumentos. Para proteger essa riqueza, que ficava diretamente nas mãos daqueles que permitiam a extração do lucro fazendo-a trabalhar, a sociedade industrial teve de apelar para a moral religiosa. A ofensiva de moralização que incidiu sobre a população do século XIX, evidente nas campanhas de cristianização junto aos operários, era necessária para constituir o povo como um sujeito moral, separado da delinquência, e acabar com "esta espécie de ilegalismo sorridente e tolerado".

A literatura policial e as páginas policiais dos jornais mostravam, pois, os delinquentes cheios de vícios, perigosos não apenas para os ricos, mas também para os pobres. ${ }^{348}$ Até o século XVIII, os crimes eram glorificados de um modo literário quando se tratava dos crimes de um rei ou de um modo popular nos folhetins que contavam as aventuras de um famoso assassino. Por volta de 1840 surge o herói criminoso, que não é nem aristocrata, nem popular, mas burguês. É neste momento que se constitui este corte entre os criminosos e as classes populares: o criminoso não deve ser um herói popular, mas um inimigo das classes pobres. ${ }^{349}$

Hobsbawm, da mesma forma, estuda uma espécie de banditismo social que esteve em voga em diversos países e que é característica de sociedades agrárias atrasadas. Poemas e baladas narravam os feitos dos bandidos rurais, considerados por sua gente heróis, campeões, vingadores, paladinos da justiça. ${ }^{350} \mathrm{Na}$ Itália, as tarantelas louvam os mafiosos da Camorra, N’drangueta e Máfia, irmanadas pelo mesmo código de conduta, a "Omerta". Em Angola, canta-se o kuduro. No México, os narcorridos exaltam traficantes e recuperam a tradição dos corridos de narrar as aventuras de heróis como Pancho Villa. ${ }^{351}$ Já no Brasil, o mais famoso bandido social foi Lampião, cujas façanhas ainda são contadas em poesia de cordel e cujo traje foi adotado por Luiz Gonzaga. ${ }^{352}$

\footnotetext{
${ }^{347}$ FOUCAULT, Michel. Vigiar e punir. 28 ed. Petrópolis: Editora Vozes, 2004. p. 54-56.

${ }^{348}$ Id. Microfísica do poder. 20 ed. Rio de Janeiro: Graal, 2004. p. 132-133.

349 Ibid. p. 136-137.

${ }^{350}$ HOBSBAWM, Eric. Bandidos. Rio de Janeiro: Forense-Universitária, 1976. p. 11. Para uma crítica da visão de Hobsbawm desse tipo de banditismo como uma atuação pré-política, irracional e individualista, cf. VIEIRA, Thiago Braga, op. cit. p. 17 et seq.

351 GUEDES, Maurício da Silva, op. cit. p. 72-73; VIEIRA, Thiago Braga, op. cit. p. 78; RUSSANO, Rodrigo, op. cit. p. 12.

352 Cf. VIANNA, Letícia C. R. Bezerra da Silva: produto do morro: trajetória e obra de um sambista que não é santo. Rio de Janeiro: Jorge Zahar, 1998. p. 48, 56.
} 
No terreno do samba, estilo musical bastante reprimido pelas autoridades policiais na primeira metade do século XX, nenhum artista representou tão bem a figura do malandro como Bezerra da Silva, inaugurador de um gênero que foi taxado pela imprensa de "sambandido". ${ }^{353}$ Nota-se, portanto, que acusações de apologia ao crime não são novidade no campo artístico e que o "proibidão" corresponde apenas a mais uma dessas manifestações. Setores artísticos da contracultura e da subcultura underground costumam adotar a figura do bandido como um transgressor, um rebelde, um marginal que questiona os valores sociais hegemônicos, e o retratam de forma positiva, por sentirem certa identificação com ele. ${ }^{354}$

A confusão entre bandido e revolucionário é criticada pelos criminólogos críticos. O primeiro tem respostas individualistas e adere às metas culturais da sociedade capitalista, apenas utilizando meios alternativos ilícitos para alcançá-las. Já o segundo propõe metas culturais diferentes. ${ }^{355} \mathrm{Na}$ década de 60 e 70, porém, parte da esquerda brasileira era simpática à ideia do bandido social como um proto revolucionário, isto é, um rebelde oriundo das classes populares, cuja carreira de violência encontrava afinidade com a ação revolucionária. Era pré-político, alienado, limitado em sua consciência dos mecanismos de dominação de classe, mas poderia ser cooptado por meio de uma conscientização política para um projeto revolucionário. ${ }^{356}$

\footnotetext{
${ }^{353}$ Bezerra foi preso para averiguação diversas vezes por não ter carteira de trabalho assinada, apesar de ser "otário", pois a polícia tinha que "fabricar vagabundo pra não perder o emprego". Tornou-se um dos mais importantes cronistas da cidade do Rio de Janeiro, dando voz a bicheiros, traficantes, policiais, delegados e ao X-9, um dos personagens mais execrados no morro e nas letras do funk "proibidão". Fez shows e foi homenageado em presídios, inclusive em Ilha Grande, tema de uma música gravada por ele e composta por um preso de lá. Muito antes dos funkeiros, foi acusado de ser amigo de bandidos, como Escadinha, de fazer apologia ao crime e teve problemas com a polícia e a censura por causa disso. Por se autoproclamar o portavoz do povo sofrido e marginalizado das favelas, Bezerra, apesar de também ser compositor, talvez para não assumir inteira responsabilidade pelo que canta, sempre preferiu realçar o seu lado intérprete, gravando sambas que recolhia com seu gravador em suas visitas aos compositores moradores do morro e da periferia, a maioria deles analfabeta: "Teve um juiz de direito que, quando eu gravei 'a semente', me disse que não era apologia porque tinha a repressão policial. Foi o juiz que condenou o Lobão. Se tiver repressão policial, deixou de ser apologia. Toda música que tiver maconha, eu meto a repressão policial. Ele me ensinou (...) A verdade tem alguma coisa com protesto. A verdade é diferente. A verdade dói e Deus dói também. Eu só canto isso" (SILVA, Bezerra da, op. cit. p. 12 et seq.). Cf. também VIANNA, Letícia C. R., op. cit. p. 45.

${ }^{354}$ No campo das artes plásticas, pode-se citar o exemplo do bandido Cara de Cavalo, cuja morte rendeu homenagens do amigo Hélio Oiticica. O lema "seja marginal, seja herói" foi associado ao movimento tropicalista como um todo e serviu de pretexto para a prisão de Caetano Veloso e Gilberto Gil em fins de 1968. A história de Cara de Cavalo e de Mineirinho, outro bandido "formado", homenageado por Clarice Lispector e Carlinhos Oliveira, é contada em VENTURA, Zuenir, op. cit. p. 37 et seq.

${ }^{355}$ DIAS, Jorge Figueiredo; ANDRADE, Manuel da Costa. Criminologia: o homem delinquente e a sociedade criminónega. Coimbra: Editora Coimbra, 1992. p. 62. É emblemático, assim, que as oligarquias brasileiras tenham feito do bandido Lampião um Capitão para perseguir o revolucionário Luiz Carlos Prestes e sua Coluna.

${ }^{356}$ XAVIER Ismail. Da violência justiceira à violência ressentida. In: Revista Ilha do Desterro, $\mathrm{n}^{\circ}$ 51. p. 55 et seq. Florianópolis, jul/dez 2006. p. 57. A verdadeira reeducação do condenado seria transformar uma reação
} 
O Brasil vivia tempos de guerrilha, em que jovens de classe média largavam os estudos ou empregos para pegar em armas, assaltar bancos e sequestrar embaixadores. Foi neste período, durante a convivência entre presos políticos de esquerda e presos comuns no presídio de Ilha Grande, que nasce o embrião do Comando Vermelho e muitas de suas regras estritas de conduta, o chamado "proceder", entre as quais não delatar, não roubar nem estuprar na cadeia, respeitar mulheres, crianças e indefesos e garantir o sustento de companheiros presos e de suas famílias. ${ }^{357}$

Na década de 60 e 70, o bandido romantizado no cinema brasileiro tinha justamente o perfil do "bandido formado" vingador descrito acima. Procurava-se, na sua história de vida, o bom moço obrigado a assumir a vida de marginal, porque vítima de uma grande violência ou injustiça social. Essa imagem do bandido se coadunava com a imagem que o próprio cineasta de esquerda tinha de si: um porta-voz da comunidade, um revolucionário, um proto-guerrilheiro enfrentando a mídia e o Estado repressor, debatendo a tarefa urgente de se completar a formação nacional, com fé na vocação emancipadora do cinema. Sua câmara era seu fuzil e a estética da violência era associada às guerras de libertação nacional.

Já na década de 90, a sociedade se mostrou mais fragmentária e conflituosa do que parecia. A sensação era de que a formação nacional havia sido abortada e o cinema brasileiro passou a exercer o papel de denunciar a barbárie da violência nos grandes bolsões urbanos de miséria, a inépcia das instituições oficiais, o colapso do sistema carcerário e o loteamento das zonas de poder pelo crime organizado. O bandido retratado no cinema brasileiro atual é vaidoso, consumista, egoísta, ressentido, um homem de negócios que leva ao extremo as regras do jogo capitalista, oprime a população, adere aos valores burgueses e se alia à própria burguesia. ${ }^{358}$

individual e egoísta, que não transforma a estrutura social, em consciência e ação política dentro do movimento de classe (BARATTA, Alessandro. Criminologia crítica e crítica do Direito Penal: introdução à sociologia do direito penal. Rio de Janeiro: Revan, 1997. p. 204).

${ }^{357}$ O nome "Comando Vermelho" faz referência à organização de esquerda COLINA, à cor do comunismo e se contrapõe às antigas falanges carcerárias, que têm conotação fascista. O extermínio sistemático dos fundadores do Comando Vermelho pela repressão e o silêncio da memória a respeito dos acontecimentos da Ilha Grande fizeram com que a liderança da facção ficasse nas mãos de rapazes cada vez mais jovens, com pouco contato com as origens do $\mathrm{CV}$. O cenário político internacional naquela conjuntura favorecia interpretações revolucionárias das práticas delinquentes. Muitos relatos levam a crer que os bandidos preferiam imaginar suas aventuras como rebeldia contra o sistema do que como delinquência individualista (VIEIRA, Thiago Braga, op. cit. p. 32 et seq.). Para uma análise da legitimidade da violência política na década de 70, cf. WIEVIORKA, Michel. O novo paradigma da violência. In: Tempo Social, vol. 9, n. 1. São Paulo, maio de 1997.

${ }^{358}$ XAVIER, Ismail, op. cit. p. 55 et seq. 


\subsection{A corrupção de menores}

Além de apologia ao crime e tráfico de drogas, uma das acusações mais recorrentes que recaem sobre os bailes funk é que neles ocorre a prática de corrupção de menores. Em julho de 1997, motivada por denúncias, a polícia apreendeu a fita de vídeo "Rio funk proibido", anunciada como "60 minutos de porrada, som e sexo agitando as galeras". A fita, gravada ao vivo, era vendida por telefone e encontrada em qualquer locadora de subúrbio do Rio de Janeiro. Nela, dançarinas tiravam a roupa ao lado de jovens, alguns com menos de 10 anos. Uma dançarina aparentando ter 15 anos de idade chega a tirar a calça de um rapaz, acariciando-o na altura da genitália. Há simulação de sexo oral e lesbianismo, mas nenhum sexo explícito.

O presidente da Liga das Equipes de Som na época, Rômulo Costa, declarou à imprensa que a fita era uma fraude, que levaram garotas de programa para o baile e que aquilo não acontecia normalmente. Já o irmão de Zezinho, dono da equipe ZZ, apesar de negar que as filmagens tivessem sido feitas em seus bailes, admitiu que situações como as do vídeo de fato existiam neles, que seu irmão oferecia 20 reais para meninas tirarem a blusa sem perguntar sua idade e que algumas tinham 15 anos, mas eram "totalmente desenvolvidas". 359

Por sua vez, em março de 2001, em meio a uma onda de grande sucesso do funk junto às camadas médias e altas dos jovens, foi divulgado com estardalhaço pelos jornais o caso de meninas de até 12 anos de idade que iam aos bailes de saias curtas, sem calcinha, e participavam de "trenzinhos" nos quais mantinham relações sexuais em plena pista de dança. As "grávidas do funk" não sabiam quem era o pai da criança e algumas alegavam até ter contraído o vírus do HIV nessas orgias. ${ }^{360}$

Antes da nacionalização do funk, no final da década de 80, o funk tocado nos bailes era instrumental ou estrangeiro. Nesta época, os dançarinos inventavam refrões em português que exaltavam suas galeras ou refrões pornográficos, para preencher o vazio. ${ }^{361}$

\footnotetext{
${ }^{359}$ ESSINGER, Silvio, op. cit. p. 186-187.

${ }^{360}$ Ibid. p. 186-187, 213-214. O juiz da $2^{\text {a }}$ Vara da Infância e da Juventude do Rio, Guaracy Vianna afirma que os donos do baile escolhiam as melhores meninas para passar pelo corredor do sexo. O primeiro que segurasse a menina tinha direito a ter relações sexuais com ela. Ela tentava escapar, nem sempre era pega por alguém que ela queria e acabava quase sofrendo um estupro. Mas quando entrava no baile, já sabia que estava sujeita a esse tipo de coisa (Ibid. p. 192).

${ }^{361}$ VIANNA, Hermano, op. cit. p. 82-83; CECCHETTO, Fátima; FARIAS, Patrícia, op. cit. p. 38. Assim, a música "Don't fight the feeling" virou a "Melô do Maconheiro", pois o refrão era entendido nos bailes como “aperta um fino" (ESSINGER, Silvio, op. cit. p. 53). Cf. também VENTURA, Zuenir, op. cit. p. 124.
} 
Hermano Vianna, ainda na década de 80, relata que dançarinas eróticas percorriam vários bailes por noite para fazer strip-tease ao som dos últimos sucessos do funk. ${ }^{362}$ Muitos menores de fato frequentam bailes funk exibindo seus corpos e simulando relações sexuais. Essas meninas são conhecidas no mundo funk como "novinhas" e homenageadas por diversos MCs.

É preciso, porém, levar em consideração que, assim como muitos jovens gostam de se afirmar simulando a filiação a uma facção criminosa, há uma distância entre o que é cantado e o que efetivamente ocorre nos bailes. As coreografias são bastante sensuais, mas "nada disso significa que se performatiza no espaço dos bailes o sexo, ao contrário do que acontecia com as rixas". ${ }^{363}$ As letras do funk com duplo sentido às vezes fazem referência ao universo infantil e são cantadas por MCs mirins, como Jonathan Costa, filho de Rômulo e Verônica Costa, da equipe de som Furacão 2000. ${ }^{364}$

O Juiz titular da $1^{\text {a }}$ Vara da Infância e da Juventude Siro Darlan, que já vinha há algum tempo de olho na presença de menores nos bailes da Furacão 2000, ameaçou tirar dos pais a guarda de Jonathan enquanto ele cantasse "músicas inadequadas". 365 Cabe questionar, no entanto, até que ponto essa erotização precoce não é um fenômeno que atinge a juventude como um todo e até que ponto legitima a intervenção estatal sob a forma repressiva:

A sexualidade parece ser tratada como um problema no qual a solução se
encontraria no acesso a conhecimentos cognitivos. A sexualidade não se resolve
no plano teórico. Os jovens procuram alternativas às limitações das
aprendizagens oficiais e treinamentos cognitivos em fontes diversas de
conhecimento: nos amigos mais velhos, nos amantes mais experientes, nas
prostitutas ou prostitutos, nas revistas de diferentes cores e matizes

${ }^{362}$ Em uma das "brincadeiras", o dançarino que tivesse uma ereção no palco poderia escolher o local onde daria um beijo na dançarina. Os dançarinos simulavam relações sexuais no palco, o que era considerado normal pelos frequentadores dos bailes (VIANNA, Hermano, op. cit. p. 92-93).

${ }^{363}$ CECCHETTO, Fátima; FARIAS, Patrícia, op. cit. p. 60. Algumas MCs que cantam funks pornográficos são evangélicas e muitos funkeiros, "representantes radicais da transgressão, parecem cheios de desejos censurados. Não falam palavrões, recalcam seus impulsos sexuais e se comportam como alunos de um rigoroso colégio interno" (VENTURA, Zuenir, op. cit. p. 79).

${ }^{364}$ Os MCs afirmam que as crianças não cantam as letras de duplo sentido com malícia. Quem tem maldade é o adulto (ESSINGER, Silvio, op. cit. p. 145, 200, 274). Segundo Fátima Cecchetto e Patrícia Farias, "o interesse desses grupos em manter essa ambiguidade pode ser visto pelo ângulo da exploração de um lado mais lúdico, cômico, e também como suavizador da carga erótica dos termos chulos. Assim, existem versões que podem 'tocar no rádio`, por exemplo, e outras que são reservadas para os bailes e os CDs piratas, 'proibidões`. Além disso, podem servir ainda para atrair um público jovem de regiões mais abastadas da cidade (...) A citação de programas infanto-juvenis pode indicar também a proximidade desses jovens com o universo infantil. Ao mesmo tempo, eles marcam sua distância desse universo, através da sátira. A distância entre a adolescência e a infância, deste modo, é construída através do alardear da atividade sexual" (CECCHETTO, Fátima; FARIAS, Patrícia, op. cit. p. 45-46).

${ }^{365}$ ESSINGER, Silvio, op. cit. p. 203. 
(pornográficas, românticas, religiosas, etc.) e, mais recentemente, também nos bate-papos da Internet (...) Os conhecimentos escolares são de fundamental importância para uma prática sexual consciente; entretanto, essa precisa ser exercitada pelos jovens, não apenas como alunos, mas como sujeitos livres para a prática autônoma do próprio corpo no tempo livre. Neste sentido, as desconfianças quanto à utilização "sadia" do tempo, e a interdição estigmatizante de espaços sociais de aprendizagem e experimentação não podem ser qualificadas como propostas de caráter democrático e cidadão. As relações sexuais entre os jovens não constituem um problema em si, podendo, pelo contrário, expressar um nível superior de qualidade de saúde pública. ${ }^{366}$

Uma parte da jurisprudência, principalmente relativa à aplicação do Estatuto da Criança e Adolescente, deixa transparecer uma visão negativa do funk, como uma espécie de ambiente criminógeno deformador da personalidade dos adolescentes, que merece repreensão e justifica o agravamento da medida sócio-educativa imposta. Trata-se, muitas vezes, de uma visão correcionalista do crime, na qual o criminoso "é um ser inferior, deficiente, incapaz de dirigir por si mesmo- livremente- sua vida, cuja débil vontade requer uma eficaz e desinteressada intervenção tutelar do Estado"367.

\author{
0328650-64.2009.8.19.0001 - APELACAO \\ DES. VALMIR RIBEIRO - Julgamento: 07/07/2010 - OITAVA CAMARA \\ CRIMINAL
}

Não merece ser acolhido o pleito alternativo de aplicação de medida sócioeducativa de liberdade assistida, considerando que o episódio pelo qual o apelante foi responsabilizado diz respeito a ato infracional que no Código Penal ostenta penalização severa e a aplicação de medida de liberdade assistida redundaria em inobservância ao princípio da proporcionalidade, que deve ter por norte a gravidade da ação praticada e a necessidade pedagógica do adolescente representado.- Ademais, o sumário social do adolescente revela que interrompeu os estudos há mais de três anos; está fazendo uso de drogas e afirmou para a psicóloga que praticou o ato infracional porque "queria dinheiro para curtir o baile", o que vem reforçar a adequação e conveniência da medida sócioeducativa aplicada, pois que possibilitará a efetiva reeducação e gradual ressocialização do jovem, visando o despertar de seu senso crítico sobre a gravidade do ato praticado, bem como de suas consequências, quer no meio social, quer para si próprio.- Recurso improvido.

\begin{abstract}
0055491-12.2008.8.19.0000 (2008.100.00075) - APELACAO (E.C.A.) DES. ANTONIO CARLOS AMADO - Julgamento: 19/08/2008 - SEXTA CAMARA CRIMINAL

Ora, apesar de ser ameaçado constantemente, continuava frequentando o baile (grifo original), assim como a Praça, onde conhece o traficante "Fê", sendo injustificável a afirmativa de que estaria armado por sofrer ameaças e temer por sua vida! (...) Apesar de não ter anotações da prática de atos infracionais, sendo sua primeira passagem pelo Juizado da Infância e da Juventude, percebe-se que o adolescente necessita de acompanhamento pelo Juizado Menorista. Embora possua apenas 14 anos de idade já frequenta bailes que se iniciam às 23 horas,
\end{abstract}

\footnotetext{
${ }^{366}$ CARRANO, Paulo César Rodrigues. Os jovens e a cidade: identidades e práticas culturais em Angra de tantos reis e rainhas. Rio de Janeiro: Relume Dumará, 200. p. 62-63.

${ }^{367}$ SHECAIRA, Sérgio Salomão, op. cit. p. 48.
} 
indo até as 04 horas da manhã do dia seguinte, com o consentimento de seus pais, ingere bebida alcoólica (cerveja) e apesar de alegar que não faz uso de drogas, percebe-se nitidamente o seu envolvimento com traficantes ("Fé" e o "pessoal da boca de Olaria”). (...) Como salienta Márcio Mothé Fernandes: Muitas infrações cometidas por adolescentes poderiam ser evitadas se os pais tivessem plena consciência de que é preciso dar liberdade aos filhos, porém, com responsabilidade. A permanência cada vez mais precoce de adolescentes em locais proibidos para menores de dezoito anos, com o consentimento dos genitores, tem corroborado de forma significativa para a prática de atos infracionais. A Justiça não dispõe de funcionários suficientes para fiscalizar a permanência de adolescentes em todos os locais, sobretudo nas grandes metrópoles. Ademais, compete aos pais, em primeiro lugar, exercer vigilância sobre os filhos, sob pena de descumprimento dos deveres inerentes ao pátrio poder. (Ação Sócio-Educativa Pública-2a Edição-Lumen Júris-p. 119) (...) Sentença que visou, antes de tudo, a ressocialização do adolescente e sua proteção integral, procurando conscientizá-lo da ilicitude de seu ato e afastá-lo do meio criminológico ao qual está exposto.

0001707-14.2005.8.19.0037 (2006.100.00063) - APELACAO (E.C.A.)

DES. ELIZABETH GREGORY - Julgamento: 25/04/2006 - SETIMA

CAMARA CRIMINAL

Quanto à aplicação da medida de internação, perfeito o Juízo de Reprovação, por ser o artigo $157, \S 2^{\circ}$, I, II E V delito de elevado potencial ofensivo, tendo sua reprimenda em casos de imputáveis, bastante severa. Por outro lado, o representado possui uma família desestruturada que não tem condições de apoiálo a retomar sua "vida bem como o representado já responde a outro processo por ato análogo ao crime de homicídio qualificado razão de seu envolvimento com a criminalidade e com gangues de bairros que se enfrentavam em baile "funk" que ocorria na cidade. Recurso que se nega provimento.

Apesar de haver seguranças e revistas nos bailes, não há evidências de que haja um controle rígido para impedir a entrada de menores de idade nesses locais. ${ }^{368}$ Por outro lado, não se pode deixar de reconhecer a prática corrente do uso de documentos falsos por adolescentes para o ingresso em discotecas e bares de classe média e alta, onde o consumo de álcool é liberado e o de drogas ilícitas camuflado. Coreografias sensuais e eróticas executadas por crianças e adolescentes, bem como letras de duplo sentido, não são exclusivas de bailes funk, sendo muito comuns no axé, marchinhas de carnaval, forró e pagode. Fazem parte, na realidade, de uma verdadeira tradição brasileira, marcada pela irreverência e sensualidade. ${ }^{369}$ Essas músicas fazem muito sucesso e são frequentes em

\footnotetext{
${ }^{368}$ Em visita ao baile da Ladeira dos Tabajaras, em Copacabana, pacificado pela Unidade de Polícia Pacificadora, constatei a presença de alguns adolescentes dançando músicas bastante erotizadas. A frequência aos bailes começa cedo, às vezes aos dez, onze ou doze anos (GUIMARÃES, Eloísa. Escola, Galeras e Narcotráfico. Rio de Janeiro: Editora UFRJ, 2003. p. 152).

${ }^{369}$ MEDEIROS, Janaína, op. cit. p. 13-14. Deize Tigrona tentou fazer carreira no hip hop e no funk melody, mas "é o duplo sentido que toca" (Ibid. p. 82-83). Cf. também FAOUR, Rodrigo. História sexual da MPB: a evolução do amor e do sexo na canção brasileira. Rio de Janeiro: Editora Record, 2006. A cultura corporal brasileira sempre teve como um marco a utilização do erótico-pornográfico. O que ocorre é que um gênero que era coadjuvante passou a ser protagonista recentemente, até por causa da globalização da lucrativa
} 
programas de TV, na rádio e em festas das camadas mais abastadas da população, assim como músicas norte-americanas com letras repletas de palavrões e que apelam para os mais baixos instintos sexuais.

As MCs mulheres abandonam a posição de passividade sexual, compõem e cantam sem qualquer pudor para "dar o troco" nos MCs machistas e seus funks. ${ }^{370}$ As letras explícitas cantadas por mulheres, ainda vistas como pessoas frágeis e românticas, que não separam sexo de sentimento amoroso, chocaram muita gente. Enquanto alguns enxergaram vulgaridade, outros detectaram um discurso político neofeminista que incomoda tanto o movimento feminista tradicional quanto a sociedade machista, a qual não admite que a mulher exija dos homens a satisfação de seus desejos sexuais e reivindique o direito de também se divertir ou até de trair. ${ }^{371}$

Talvez haja ainda um componente racista na condenação do "pornofunk". Ao contrário de grupos da militância negra, como os rappers, os funkeiros não afirmam expressamente sua identidade negra, mas a "sugerem, através de sua própria presença, da visibilidade que adquirem, colocando em cena seus corpos coreograficamente arranjados". Haveria uma provocação não-verbal, provocando o conflito e levando à armadilha do estereótipo que associa o corpo negro à sexualidade e os negros à irracionalidade. ${ }^{372}$

\subsection{O caso Tim Lopes}

Um episódio que contribuiu decisivamente para o processo de demonização do funk foi o sequestro e assassinato do repórter investigativo Tim Lopes em 2002. Tim já havia feito, nas décadas de 80 e 90, reportagens sobre os bailes funk do subúrbio carioca. Nelas, era como se o jornalista mergulhasse anonimamente em um submundo exótico e perigoso para mostrar aos leitores dos jornais o que se passava na mesma cidade em que

indústria do sexo e pornografia, que, mais do que acabar com tabus corporais, cria um "erotismo funcional", uma "sexualidade consumista" (CECCHETTO, Fátima; FARIAS, Patrícia, op. cit. p. 56 et seq.).

${ }^{370}$ CECCHETTO, Fátima; FARIAS, Patrícia, op. cit. p. 41, 46-47, 50, 52-53.

${ }^{371}$ É costume das MCs rejeitar nas letras as atividades desenvolvidas comumente pelas mulheres das classes populares e recusar papéis subalternos. Entretanto, parecem incorporar a subcultura machista ao glamorizarem bens de consumo, atribuírem ao homem o papel de provedor e tomarem a sexualidade como dádiva, negociando o sexo em troca de bens (CECCHETTO, Fátima; FARIAS, Patrícia, op. cit. p. 48).

372 "A resposta corporal proposta pelo pornofunk faz parte da dinâmica racial brasileira, cuja tônica não é a confrontação verbal, voltada para a ação política" (Ibid. p. 55-56). 
residiam e que permanecia por eles ignorado. ${ }^{373} \mathrm{O}$ aspecto da violência era realçado de forma sensacionalista.

Um ano antes de ser assassinado, Tim Lopes havia ganhado o prêmio Esso em razão de uma matéria que fizera sobre a "Feira livre das drogas". Portando uma câmera escondida, Tim filmou a venda de drogas em favelas do Rio de Janeiro. Quando a denúncia da mídia foi ao ar, a polícia se sentiu pressionada a dar uma satisfação à sociedade, o que na maioria das vezes significa reprimir violentamente os traficantes. Se os traficantes punem severamente o morador que faz confusão na favela, atraindo a polícia e atrapalhando o movimento do tráfico, é natural que Tim Lopes tenha se tornado persona non grata para eles. ${ }^{374}$

No entanto, isso não impediu que, mesmo tendo o seu rosto divulgado por ocasião do prêmio, Tim tenha mais uma vez aproveitando sua aparência comum, se disfarçado de "morador", para, munido de uma câmera escondida, verificar uma suposta denúncia feita por um morador desesperado e descrente na atuação do Poder Público, de que menores eram obrigadas a se prostituir e drogas eram consumidas no baile funk da Vila Cruzeiro, na Penha. O repórter teria ido à favela três vezes. Durante a semana, só teria conseguido registrar a movimentação de traficantes armados, não a suposta orgia de menores.

Ao retornar, dia 2 de junho, para documentar o baile, Tim foi descoberto pelo chefe do tráfico local, Elias Maluco, submetido a um "julgamento", morto com uma espada de samurai e teve seus restos mortais queimados em uma espécie de vala clandestina conhecida como "microondas". ${ }^{375}$ Nos dias seguintes, a mídia fez estardalhaço sobre o caso, equiparando o assassinato de Tim a um atentado contra a liberdade de imprensa e a democracia $^{376}$, realizado por traficantes selvagens, que oprimem os moradores do morro e

373 Cf. ESSINGER, Silvio, op. cit. p. 131; VENTURA, Zuenir, op. cit. p. 216. Já na década de 70, o movimento Black Rio não viu com bons olhos a pioneira matéria da jornalista Lena Frias. Embora tenha ajudado a torná-lo conhecido, chamou a atenção das autoridades policiais, que não aprovaram aquelas aglomerações de negros em plena ditadura militar, conforme será examinado no capítulo seguinte (VIANNA, Hermano, op. cit. p. 27).

${ }^{374} \mathrm{O}$ recurso à imprensa pelos moradores da favela é empregado com cautela pela falta de confiança nos repórteres e pelos problemas que uma reclamação pública pode causar. "Chamar a imprensa" é uma faca de dois gumes, pois mesmo os traficantes sabem que a veiculação constante de seus nomes nos jornais incita o recrudescimento da ação policial, ameaçando-lhes a sobrevivência (ALVITO, Marcos, op. cit. p. 150).

375 ESSINGER, Silvio, op. cit. p. 241; MORETZSOHN, Sylvia. O caso Tim Lopes: o mito da "mídia cidadã”. In: Discursos Sediciosos: crime, direito e sociedade, vol. 12. Rio de Janeiro: Editora Revan, 2002. p. 304.

${ }^{376}$ Samuel Wainer já afirmava que "jornalista, como sabemos, não pode sequer ser agredido, muito menos morrer: para os demais jornalistas, trata-se de uma espécie de atentado ao patrimônio nacional”. A morte sob espancamento do jornalista Nestor Moreira, dentro de uma delegacia, vinha demonstrar que a prática não havia cessado com a redemocratização do país após o Estado Novo e serviu para um grande questionamento da polícia carioca (VENTURA, Zuenir, op. cit. p. 24-25). 
querem calar, usando práticas terroristas, quem os denuncia. Tim foi alçado a mártir e a pressão para que a polícia encontrasse Elias Maluco foi tão grande que não tardou para que o prendesse, em circunstâncias bastante suspeitas.

Algumas indagações podem ser feitas a respeito deste caso. Pode-se questionar, em primeiro lugar, até que ponto cabia a um jornalista apurar uma denúncia daquela espécie. Há um componente ideológico fortíssimo por trás do próprio conceito de reportagem investigativa. No contexto do neoliberalismo, o Estado, desacreditado, é substituído por "empresas cidadãs" e pela mídia, o quarto poder, que conta com a confiança do cidadão, embora os mecanismos de elaboração da notícia não sejam totalmente transparentes, sendo permeados por interesses político-econômicos, e embora a concentração dos meios de comunicação e a estrutura de um jornal não sejam muito democráticas. ${ }^{377}$ No Acórdão que julga a Apelação interposta por José Cláudio Braga, o Zezinho, dono da equipe de som ZZ, esta imagem fica clara:

0143838-96.2000.8.19.0001 (2001.050.04074) - APELACAO

DES. NESTOR LUIZ BASTOS AHRENDS - Julgamento: 21/05/2002 SEGUNDA CAMARA CRIMINAL

QUEIXA-CRIME. REJEIÇÃO. LEI DE IMPRENSA. FALTA DE JUSTA CAUSA. NÃO CARACTERIZAÇÃO DA RESPONSABILIDADE SUCESSIVA.

Decorreu a queixa-crime por entender o querelante ter sido alvo de injúria, calúnia e difamação, pois em 23 de julho de 2000 foi surpreendido ao ler e ver seu nome envolvido em matéria jornalística publicada no Jornal Extra que fez constar de forma absurda o relato de uma pessoa até hoje desconhecida pelo querelante e por todos. E, ainda, afirmando que o querelante mantinha um esquema de tráfico de drogas e exploração de menores nos bailes Funk. No caso, o apelado/querelado Eduardo Auler conforme informou em sua defesa prévia foi procurado por Carlos Alberto de Oliveira, fornecendo a este informações sobre a criminalidade nos bailes funk, concedendo uma entrevista que foi gravada em fita cassete. Após averiguações e pesquisas sobre o assunto elaborou, assinou e publicou matéria jornalística, objeto da presente queixa-crime. A meu ver, correta a decisão que rejeitou a queixa-crime. A uma, porque a reportagem indicada na inicial, não é matéria opinativa, mas noticiosa, não constituindo abuso no exercício da liberdade de informação. Afirmando a notícia a existência de uma testemunha que declarou que o querelante, juntamente com seu sócio, mantém um esquema de tráfico de drogas e exploração de menores nos "bailes funks" realizados na região metropolitana do Rio de Janeiro, reportagem essa elaborada com base em dados oficiais colhidos pelo jornalista, primeiro querelado, não restando configurado o "animus injuriandi" em sua conduta.

O repórter investigativo avoca o fardo de representante do cidadão indignado e se arvora o direito de usar, na sua heróica e cívica missão de informar e "abrir os olhos do Estado", meios que em um Estado Democrático de Direito os particulares não poderiam

${ }^{377}$ MORETZSOHN, Sylvia, op. cit. p. 294. 
utilizar. O uso de câmeras ocultas, por exemplo, é bastante questionável. Em primeiro lugar, gera a falsa impressão de transparência, de que os "fatos falam por si" e oculta a interpretação dada à realidade pela mídia parcial, a edição, os interesses do jornal e das fontes, o comportamento do "repórter sem rosto", que muitas vezes, em busca de notícia, pode induzir o comportamento criminoso, e a própria seletividade do que deve ser notícia. Juridicamente, as imagens geradas por câmeras ocultas sem autorização judicial são provas ilícitas, fazendo com que o Estado fique ainda mais desacreditado pelo cidadão indignado com as imagens. ${ }^{378}$

O uso de câmeras ocultas induz à "preguiça apurativa", ao "sensacionalismo voyeurista" e faz com que o jornalista perca a sua única proteção, a sua credencial de jornalista, pois acaba se confundindo com espião, informante, o detestado X-9, ou policial. ${ }^{379}$ Além disso, assim como o sigilo das fontes, faz parte da ética do jornalista identificar-se como tal e informar o entrevistado de que ele está sendo gravado. De qualquer forma, pode-se questionar a credibilidade da versão do caso Tim Lopes aceita como verídica, como de fato foi questionada, em 2003, pelo livro "Dossiê Tim LopesFantástico/Ibope, do jornalista Mário Augusto Jakobskind. Não era ideia de Tim cobrir essa matéria e o morador denunciante que motivou a investigação nunca foi identificado ou encontrado. O horário em que Tim supostamente subiu o morro pela última vez não é verossímil, tendo em vista a hora em que começava o baile. Também parece estranho que um repórter tão experiente tenha sido alvo tão fácil de traficantes. ${ }^{380}$

Por fim, pode-se questionar o próprio sentido da matéria de Tim Lopes. O consumo de drogas e a presença de menores nos bailes de comunidade são de conhecimento público

\footnotetext{
${ }^{378}$ MORETZSOHN, Sylvia, op. cit. p. 297.

${ }^{379}$ Ibid. p. 305-306. Paulo César Rodrigues Carrano relata que no baile do Fire Clube observou traficantes, muitos adolescentes consumindo bebidas alcoólicas, quartos aparentemente utilizados para encontros sexuais e policiais militares fardados e armados de metralhadoras recebendo um envelope das mãos de um homem, na tesouraria. Sem dúvida, uma combinação explosiva para ser gravada, tanto que o diretor do clube deixou o pesquisador entrar, mas "sem máquina de filmar, retrato ou gravador" (CARRANO, Paulo César Rodrigues, op. cit. p. 65-67). Há uma certa "'ética` que move as ações tanto de moradores quanto de intrusos. Uma foi a dos 'repórteres`, 'jornalistas`e similares, na sua ânsia de tudo registrar. Sua arma, a câmera fotográfica, era informal mas expressamente 'proibida' na favela. Muitos, em dia de comemoração, protestos e 'visitas' à Casa da Paz- momentos em que o tráfico é avisado da presença de estranhos-, tentavam mirar suas lentes para a boca e eram repreendidos. Outra imagem é a do X-9, seja ele do funk ou do tráfico (...) Ambos, o jornalista e o X-9, trabalham com a informação. Assim, cada vez mais o silêncio era uma demonstração de desinteresse ou, quem sabe, um 'respeito` pelos limites instituídos por alguém ou alguns com relação à natureza de certas informações. Não há meio-termo, posição intermediária, palavra indefinida. O campo é de guerra. A observação e o que dela resulta, a informação, deve servir a alguém (CUNHA, Olívia M. G. Bonde do mal. In: In: MAGGIE, Yvonne; REZENDE, Cláudia B. (Org). Raça como retórica: a construção da diferença. Rio de Janeiro: Civilização Brasileira, 2001. p. 127).

${ }^{380}$ Apud ESSINGER, Silvio, op. cit. p. 242.
} 
e notório e a gravação das imagens, portanto, mais do que informar, teria um apelo sensacionalista e voyeurista típico dos reality shows, o que é muito lucrativo para os donos dos meios de comunicação, mas não justifica colocar a vida de um funcionário em risco. Ademais, as câmeras ocultas, apesar da aparência de captar de forma neutra e objetiva a realidade como ela é, nua e crua, não é isenta, possuindo filtros ideológicos. É muito simbólico que mais uma vez um baile funk tenha sido alvo destas câmeras criminalizantes e não baladas de jovens de classe média e alta, festas de socialites, delegacias de polícia, processos seletivos para atores adolescentes em busca de estrelato midiático ou redações de jornais. A seletividade do sistema penal se mostra a mesma no terreno da mídia cidadã e democrática, legitimando a repressão. ${ }^{381}$

Embora o cemitério clandestino já existisse em Vila Cruzeiro e moradores da favela tenham sido executados e torturados antes de Tim Lopes, é com a morte do jornalista que o banal e o cotidiano voltam a ser alardeados como inadmissíveis. Poucos dias depois do desaparecimento de Tim, um casal também foi preso, torturado e assassinado quando entregava uma cesta de café da manhã no dia dos namorados, nas cercanias de uma favela no subúrbio carioca. A mídia, no entanto, tratou o caso de forma muito mais discreta, talvez para não desconcentrar a exploração do caso Tim Lopes. A imprensa e a "opinião pública" parecem se escandalizar com a violência apenas em dois casos: quando ela se manifesta em massacres que envergonham o país perante o mundo (Candelária, Carandiru, Eldorado) e quando ela se exerce contra pessoas da elite ou da classe média. ${ }^{382}$

A óptica criminalizante tanto da matéria que Tim faria quanto das matérias que sucederam sua morte vinculou ainda mais os bailes funk à barbárie, cumprindo um ciclo vicioso perverso. Enquanto os criminosos envolvidos foram, um a um, sendo presos ou mortos, integrantes do mundo funk, especialmente o DJ Marlboro e Hermano Vianna,

\footnotetext{
${ }^{381}$ MORETZSOHN, Sylvia, op. cit. p. 304-305. A opinião pública, portadora da ideologia dominante e ativadora dos processos informais de reação ao desvio e à criminalidade, é importantíssima para a sustentação e legitimação do vigente direito penal desigual através de estereótipos e teorias de senso comum. Por essa razão, ela é manipulada pelas forças políticas em momentos de crise do sistema de poder através de alarmes sociais, que obscurecem a consciência de classe e produzem uma falsa representação de solidariedade que unifica todos os cidadãos na luta contra um inimigo interno comum. Sobrepondo muitas vezes a imagem do terrorismo à imagem de dissenso em face do sistema político, como, por exemplo, está ocorrendo atualmente nos EUA mediante a "Guerra contra o Terror", as campanhas de "Lei e Ordem" legitimam o abandono de garantias constitucionais conquistadas pela burguesia. Para os criminólogos radicias, é preciso, pois, reverter as relações de hegemonia cultural, com um trabalho de crítica ideológica, produção científica e informação (BARATTA, Alessandro, op. cit. p. 204-205).

382 Ibid. p. 308-309. Da mesma forma, a mídia monopolizada manteve fora das manchetes a "bárbara sequência de execuções" dos suspeitos do caso Tim Lopes. As lamentações giraram mais em torno das preocupações com a "queima de arquivo" do que com as execuções em si (BATISTA, Vera Malaguti. $O$ medo na cidade do Rio de Janeiro: dois tempos de uma história. Rio de Janeiro: Revan, 2003. p. 104-105).
} 
apresentavam argumentos para que aquele baile da Vila Cruzeiro fosse isentado de culpa pela tragédia. Orlando Zaccone, delegado titular, desde 2003, da 19 a DP, na Tijuca, reconhece que o tráfico patrocina alguns bailes de favela, mas reitera que "aquilo ali foi só uma desculpa", porque na verdade Tim Lopes não morreu nem dentro do baile funk. Ele foi pego fora do baile e levado para outro lugar.

A palavra "funk", entretanto, foi demonizada e, para que os bailes funk continuassem ocorrendo, tiveram que mudar sua denominação para baile de charme ou de pagode-charme. Segundo Zaccone, os delitos investigados não têm nada a ver com a música funk e podem ser cometidos em shows como o Rock in Rio, mas "as pessoas são mais condescendentes com as práticas criminosas quando o evento é voltado mais para as classes médias e altas". ${ }^{383}$ Para Hermano Vianna, o Estado deveria aproveitar a vitalidade do funk de uma forma construtiva, fiscalizando os bailes, regulamentando o mercado, fornecendo infra-estrutura adequada e utilizando as estrelas mais populares em campanhas sociais ou educacionais. Se a mídia e o poder público "tivessem tido (...) uma atitude menos preconceituosa e mais colaborativa diante dos bailes, e não buscassem o tempo todo isolá-los numa terra de ninguém, a tragédia de Tim Lopes poderia ter sido evitada". 384

\footnotetext{
${ }^{383}$ Apud ESSINGER, Silvio, op. cit. p. 242-243. O DJ Marlboro lembra o episódio de um homem que apareceu morto na praia de Botafogo. A imprensa, desavisadamente, acusou os frequentadores do baile do Manequinho. O baile funk do Botafogo, entretanto, sempre acontecia aos domingos e o cadáver foi encontrado numa quarta-feira, sendo que na semana anterior não havia acontecido o baile por intervenção do próprio governo. Marlboro critica manchetes duvidosas, como "Saiu do baile funk e morreu baleado". Descobre-se, depois, que o sujeito pode até ter saído do tal baile, mas morreu bem longe dali, por outro motivo qualquer, até mesmo passional (SALLES, Lúcia, op. cit. p. 42). Em setembro de 1995, o jornal O Dia noticiou que "dez jovens, entre eles uma menina aparentando 11 anos, foram assassinados a tiros e quatro ficaram feridos ontem de madrugada, numa vila de acesso ao Morro do Turano, no Rio Comprido, onde era realizado baile funk (...) A polícia atribui a chacina à guerra entre traficantes". O que os jornais não enfatizaram foram as declarações de dois delegados, que, diante de algumas evidências como o grosso calibre das armas utilizadas, bem como o fato de os corpos terem sido retirados do local, descartavam a "possibilidade de briga entre funkeiros". Mas se as mortes não tinham sido provocadas pelos funkeiros, tinha sido produzida durante (grifo no original) os bailes (CUNHA, Olívia M. G. Cinco vezes favela- um reflexão. In: ALVITO, Marcos; VELHO, Gilberto (Org.). Cidadania e Violência. Rio de Janeiro: UFRJ e FGV, 1996. p. 204-205).

384 Apud MEDEIROS, Janaína, op. cit. p. 102-103.
} 


\section{CRIMINOLOGIA CRÍTICA E CRIMINALIZAÇÃO DO FUNK}

\subsection{A criminologia crítica}

Os teóricos do labelling aproach já haviam percebido como a criminalização primária e secundária são frutos de relações de poder dentro de uma sociedade desigual e conflituosa, onde, ao contrário do que defendem os funcionalistas, inexiste um núcleo central de bens jurídicos cujas violações corresponderiam a delitos naturais. Entretanto, embora reconhecendo a desigualdade política na distribuição de status positivos e negativos na sociedade e a seletividade do sistema penal, o labelling approach permaneceu em contextos teóricos subjetivos e idealistas. Não ultrapassou os limites do modelo de sociedade capitalista para fazer a sua crítica e, portanto, não foi capaz de compreender as razões econômicas da desigualdade de poderes de definição nem tampouco explicar as origens mediatas da desvio e as causas da reação social. ${ }^{385}$

A inovação trazida pela criminologia crítica em relação ao labelling approach reside no fato de haver interpretado e não somente descrito a fenomenologia da desigualdade substancial, referente às chances de ser definido e controlado como desviante ${ }^{386}$, penetrando em sua lógica objetiva, que reside na estrutura das relações sociais de produção. A criminologia crítica explicitou, com muita propriedade, como o sistema penal, inserido no sistema global de controle social, na realidade não só reflete as relações de desigualdades sociais, mas também serve para produzir e reproduzir essas desigualdades e conservar a realidade social.

Há uma maior perseguição aos crimes cometidos pelas camadas inferiores da população, que atingem principalmente a propriedade privada, e uma imunização de condutas cometidas pelos detentores do poder, socialmente mais danosas e imorais, mas funcionais ao processo de acumulação capitalista, tais como a criminalidade econômica, ambiental, organizada, política, das relações de trabalho e racista. ${ }^{387}$

Segundo a criminologia crítica, a seletividade e desigualdade do direito, bem como a criminalidade, só podem ser devidamente entendidas em um enfoque macrossociológico,

\footnotetext{
385 BARATTA, Alessandro. Criminologia crítica e crítica do Direito Penal: introdução à sociologia do direito penal. Rio de Janeiro: Revan, 1997. p. 211-212.

386 Ibid. p. 164.

387 DIAS, Jorge Figueiredo; ANDRADE, Manuel da Costa. Criminologia: o homem delinquente e a sociedade criminógena. Coimbra: Editora Coimbra, 1992. p 257.
} 
inseridas no contexto social capitalista, imposto pela desigualdade e marcado pela luta de classes. ${ }^{388}$ De acordo com Marx, o crime e o direito fazem parte da superestrutura da sociedade, que varia conforme se altera o sistema de produção, ou seja, sua infraestrutura ou base econômica. Em outras palavras, o crime seria decorrência natural de certas estruturas econômicas específicas e modificáveis. ${ }^{389}$

O direito é considerado, desta forma, ideologia, pois mascara as contradições da sociedade e da luta de classes, alegando uma suposta igualdade de tratamento dos indivíduos e forjando um falso consenso quanto aos bens que a sociedade, supostamente homogênea em sua totalidade, deseja proteger. Os críticos negam a visão durkheimeanafuncionalista de que é função do crime estabelecer e preservar os limites morais da comunidade, supondo que os atos criminosos supostamente ofenderiam a moralidade do povo e contribuiriam assim, para uma maior solidariedade entre seus membros.

Na visão marxista, o crime contribui para a estabilidade política, pela legitimação do monopólio do Estado sobre a violência e o controle político legal das massas, bem como para a estabilidade econômica temporária em um sistema econômico que é intrinsecamente instável, ocultando situações negativas e sofrimentos reais nas classes menos favorecidas, encobrindo confrontações violentas entre as classes sociais orientando a hostilidade do oprimido para longe dos opressores e em direção à sua própria classe. ${ }^{390}$

O elemento ideológico, objeto de conhecimento da criminologia crítica, não é contingente, mas inerente à estrutura e à forma de funcionamento do sistema penal e tem como função reproduzir e manter a desigualdade, legitimar as relações, produzir um consenso real ou artificial. ${ }^{391}$ A impossibilidade de superar as contradições no interior do sistema penal desenvolve-se através de aperfeiçoamentos ideológicos e melhoramentos técnicos, e do enfrentamento o problema da marginalização social sem incidir na estrutura da sociedade capitalista, que, apesar de pregar a prosperidade material, tem necessidade de desempregá-los e, por motivos ideológicos e econômicos, de marginalizá-los criminalmente. $^{392}$

\footnotetext{
${ }^{388}$ ELBERT, Carlos Alberto. La criminologia del siglo XXI em América Latina. Buenos Aires: RubinzalCulzoni, 1999. p. 105.

389 SHECAIRA, Sérgio Salomão. Criminologia. São Paulo: Revista dos Tribunais, 2004. p. 49.

390 BARATTA, Alessandro, op. cit. p. 333-334.

391 Ibid. p. 213-214.

${ }^{392}$ Ibid. p 190.
} 


\subsection{Moralismo e paternalismo penal}

Não se pode negar a forte carga moralista contida na condenação do funk. Becker acentua o papel dos empreendedores morais criadores de regras, que, como reformadores cruzados, operam com uma ética absoluta, muitas vezes hipócrita. Eles julgam que nada pode estar certo no mundo até que se façam regras para corrigi-lo. Apesar de parecerem ser intrometidos, interessados em impor sua própria moral aos outros, muitos cruzados morais têm fortes motivações humanitárias, pois acreditam que se as outras pessoas fizerem o que é certo, será bom para elas. Eles acrescentam ao poder que extraem da legitimidade de sua posição moral o poder que extraem de sua posição superior na sociedade. ${ }^{393}$

Para Emile Durkheim, a razão de uma conduta ser criminalizada resulta da sua aptidão para ferir a denominada por ele de "consciência coletiva", isto é, o conjunto de valores compartilhados que conferem à sociedade coesão e tem sua origem na solidariedade mecânica que advém da semelhança e identificação entre os indivíduos. ${ }^{394}$ David Garland, no entanto, aponta que, se por um lado o Direito Penal não consegue se impor por muito tempo sem grandes resistências sem que suas normas observem minimamente a moral da sociedade, por outro lado esta moral pode ser instrumentalizada e manipulada por uma elite com o intuito de que seus interesses de classe sejam alcançados. $^{395}$

A criminologia crítica demonstra que a moralidade se altera conforme as necessidades do mercado de trabalho. No fim do século XVI, por exemplo, em virtude de guerras religiosas, do crescimento significativo das forças armadas, da emigração, dos impostos excessivos, do aumento do preço dos alimentos e do cercamento dos campos, o crescimento demográfico não acompanhou as possibilidades de emprego, decorrentes do desenvolvimento econômico causado pelos setores urbanos, o crescimento do sistema financeiro, a extensão dos mercados, os metais preciosos e a conquista das colônias.

A escassez de mão-de-obra implicou no aumento dos ordenados, de modo que na França, o mesmo Estado que apenas algumas décadas mais tarde foi acusado pelos capitalistas de ser artificial e ter violado a lei da natureza, foi chamado para intervir em favor dos empregadores para garantir a redução dos salários e a produtividade do capital

\footnotetext{
${ }^{393}$ BECKER, Howard. Outsiders: estudos de sociologia do desvio. Rio de Janeiro: Zahar, 2009. p.153-155. ${ }^{394}$ DURKHEIM, Émile. Da divisão do Trabalho Social. São Paulo: Martins Fontes, 1995. p. 39 et seq. 395 GARLAND, David. Punishment and modern society: a study in social theory. Chicago: Oxford University Press, 1993. p. 53 et seq.
} 
necessária para a extensão dos mercados e a aquisição de equipamentos técnicos. O mesmo Estado que aderiu mais tarde à teoria malthusiana, imprimiu uma política de estímulo à taxa de natalidade, apoiada pelo clero e seu dogma "crescei e multiplicai-vos".

Famílias com numerosos filhos tinham seus impostos reduzidos, proibiu-se a punição das mães solteiras para diminuir os casos de infanticídios, emanou-se o decreto contra o ano de luto das viúvas, que as impedia de contrair matrimônio nesse prazo, garantiu-se posição legal favorável a crianças ilegítimas. Como forma de contornar a baixa taxa de natalidade e a consequente escassez de mão-de-obra, que elevava os salários, os Stuarts favoreceram na Inglaterra as festividades populares do May Day. Afinal, mesmo que as donzelas perdessem suas virtudes, o rei ganhava novos súditos. ${ }^{396}$

Por outro lado, no século XVI, a Igreja e o Estado tentaram por toda parte, aparentemente com muito pouco sucesso, proibir os jogos de azar, em parte por causa das perdas de dinheiro que deles podiam resultar às pessoas sem fortuna, em parte em razão das rixas que provocavam, mas, sobretudo, porque eles contribuíam à blasfêmias, pois sob o efeito da ira muitos homens deixavam escapar palavras injuriosas a Deus, à Virgem ou aos santos. ${ }^{397}$ Os jogos de azar não eram os únicos acusados de serem antros propiciadores de blasfêmias, mas também qualquer outro espaço em que se manifestasse uma cultura popular ainda medieval e pagã, como feiras e tabernas, "esses espaços tenebrosos, tantas vezes paredes meias com a Igreja, nos quais o álcool, a música e o jogo e uma convivência calorosa em excesso descambam geralmente em discussões, insultos, rixas e agressões ou homicídios, e onde Deus não é poupado". 398

\footnotetext{
396 RUSCHE, Georg; KIRCHHEIMER, Otto. Punição e estrutura social. 2.ed. Rio de Janeiro: Revan: Instituto Carioca de Criminologia, 2004. p. 43 et seq. Para Foucault, desde o século XVIII, vive-se na era da governamentalidade, em que o Estado é definido pela massa da população, com seu volume, sua densidade. Este Estado de governo tem essencialmente como alvo a população e utiliza a instrumentalização do saber econômico. O objetivo do governo torna-se melhorar a sorte da população, aumentar sua riqueza, sua duração de vida, sua saúde, etc. Para isso, utilizará campanhas, através das quais se age diretamente sobre a população, e técnicas que vão agir indiretamente sobre ela e que permitirão aumentar, sem que as pessoas se deem conta, a taxa de natalidade ou dirigir para uma determinada região ou para uma determinada atividade os fluxos de população, etc. Quando se quiser obter alguma coisa da população quanto aos comportamentos sexuais, à demografia, ao consumo, etc., é pela família que se deverá passar, como demonstram as campanhas contra a mortalidade, relativas ao casamento, a vacinação, etc. (FOUCAULT, Michel. Microfísica do poder. 20 ed. Rio de Janeiro: Graal, 2004. p. 289 et seq).

${ }^{397}$ DELUMEAU, Jean. História do medo no Ocidente. 4. Ed. São Paulo: Companhia das Letras, 1999. p. 407.

${ }^{398}$ DUARTE, Luís Miguel. A boca do diabo: a blasfêmia e o direito penal português da Baixa Idade Média. In: Lusitania Sacra. $2^{\mathrm{a}}$ série, 4. Lisboa: Porto, 1992. p. 66. Um regulamento para as companhias de caridade das paróquias parisienses do século XVII estabelece que os membros da companhia "trabalharão para impedir os maus locais, tabacarias, academias, jogos, escândalos públicos, blasfêmias, impiedades, e outras desordens que possam chegar a seu conhecimento". É preciso se informar direito de que maneira os pobres "se comportam em casa, mantêm paz entre si e com os vizinhos, se têm o cuidado de criar os filhos no temor
} 
A elite no poder exigia a cristianização da vida cotidiana de maneira autoritária e a radical separação entre sagrado e profano. Satã introduzia-se nos divertimentos, perverteraos, paganizara-os, servindo-se deles para confundir as hierarquias e perturbar a ordem social. Desta forma, diversas festas pagãs foram proibidas pela Igreja Católica e pelos protestantes, assim como fogueiras de São João, algazarras, cerimônias festivas de casamento, batismo, Natal, música, banquetes, etc. As festas eram responsabilizadas pelas querelas, disputas, ódios, inimizades, espancamentos, assassinatos, devassidão, bebedeira, perturbação das missas, palavras sujas, folias imprudentes e desonestas, seduções, obras da carne e uma infinidade de semelhantes desordens que desonravam o nome e a religião de Jesus Cristo. ${ }^{399}$

Condutas associadas ao hedonismo, como a vadiagem, a prostituição, o adultério, a homossexualidade, o jogo e o consumo de álcool e drogas encontravam uma forte oposição de inspiração religiosa antes mesmo do capitalismo. Porém, o que deve ser questionado é a razão de algumas condutas consideradas imorais serem criminalizadas e outras não. A hipótese aqui defendida é que, com a ascensão do capitalismo mercantil e a necessidade de disciplinar a mão-de-obra para o trabalho das manufaturas e posteriormente das fábricas, as condutas tradicionalmente consideradas imorais referidas acima ganharam um outro status, os de condutas disfuncionais tanto para a economia quanto para afirmar a nova ideologia e ética que legitimavam o novo modo de produção. ${ }^{400}$

A função das diversas instituições subalternas às manufaturas e fábricas, como a família mononuclear, a escola, o cárcere, o hospital, o quartel, o convento e o manicômio, passa ao garantir ao capital uma força de trabalho disciplinada no novo modo de produção capitalista, que, por atitudes morais, saúde física, capacidade intelectual, conformidade às regras, hábito à disciplina e à obediência, pudesse facilmente se adaptar ao regime de vida

de Deus... se não deitam os filhos crescidos de sexo diferentes juntos e com eles, se não há libertinagem e carícias nas famílias, principalmente para com as filhas crescidas. Se há dúvida de que sejam casados, é preciso pedir-lhes uma certidão de casamento (FOUCAULT, Michel. Vigiar e punir. 28 ed. Petrópolis: Editora Vozes, 2004. p. 175).

${ }^{399}$ Condenam-se os vestígios do "paganismo", a contaminação do sagrado por um profano invasor, os ruídos, clamores e libertinagens próprias dos divertimentos báquicos das multidões não controladas, enquanto se exalta a festa cristã recolhida, ordenada, meditativa e acompanhada de oração que terá rompida com as "corrupções", "vaidades", "bobagens" e "folias" em que se compraz a "populaça" (DELUMEAU, Jean, op. cit. p. 407 et seq.).

400 A seletividade do Direito Penal fica patente quando se observa a contravenção penal de "vadiagem", prevista no artigo 59 da Lei das Contravenções Penais. Deixar de trabalhar tendo recursos para se sustentar pode até ser condenável moralmente, mas não a ponto de se tornar como uma contravenção penal e muito menos um crime. 
na fábrica e produzir, assim, a quota máxima de mais-valia passível de ser extraída em determinadas circunstâncias. ${ }^{401}$

Foucault destaca, como originalmente cabia às disciplinas, essa função negativa, de neutralizar os perigos, fixar as populações inúteis ou agitadas, evitar os inconvenientes de reuniões muito numerosas. Assim, a justificativa dada para a criação das escolas de província ou nas escolas cristãs do século XVII era a de educar as crianças, já que seus pais não não os educavam, o que contribuiu no combate à ignorância sobre Deus, a preguiça (com todo o seu cortejo de bebedeira, de impureza, de furtos, de banditismo) e a formação de tropas de mendigos, sempre prontos a provocar desordens públicas. Somente depois as disciplinas ganharam uma função positiva, a de aumentar a utilidade possível dos indivíduos. $^{402}$

Os regulamentos fabris, tendo como pretexto o bem do empregado, referentes a moral e aos bons costumes, regulavam suas vidas privadas protegendo-os de situações que poderiam afetar sua produtividade ou disciplina. Uma grande importância era dada à ordem e à limpeza, ao vestuário uniforme, à comida e ao ambiente saudável. Proibiram-se a blasfêmia, o uso do jargão popular e obsceno, os livros ou cartas, as canções ou baladas que não fossem ordenadas pelos diretores, os jogos e apelidos, com o objetivo de despedaçar uma cultura popular subterrânea, que representava uma encruzilhada das velhas formas de vida camponesa recém-abandonada com as formas novas de resistência ao novo estilo de vida. $^{403}$

As instituições de sequestro deveriam controlar, formar, reformar e corrigir os corpos dos indivíduos na sua totalidade, já que este deveria adquirir aptidões, receber certo número de qualidades, qualificar-se como corpo capaz de trabalhar, ou seja, transformar-se

${ }^{401}$ MELOSSI, Dario; PAVARINI, Massimo. Cárcere e fábrica. Rio de Janeiro: Revan: Instituto Carioca de Criminologia, 2002. p. 47-48, 73 et seq.; BITENCOURT, Cezar Roberto. Falência da pena de prisão: causas e alternativas. 2 ed. São Paulo: Saraiva, 2001. p. 24-25. Algumas dessas instituições, como o cárcere, o quartel, o manicômio e o convento são chamadas por Foucault de instituições de sequestro e por Ervin Goffman de instituições totais. Cf. GOFFMAN, Ervin. Manicômios, prisões e conventos. São Paulo: Perspectiva, 1996. p. 24 et seq. Sobre a importância da ética puritana para o empobrecimento cultural do operário, cf. WEBER, Max. A ética protestante e o espírito do capitalismo. São Paulo: Companhia das Letras, 2004. p. 152-153.

${ }^{402}$ FOUCAULT, Michel. Vigiar e punir. 28 ed. Petrópolis: Editora Vozes, 2004. p. 173-174. Segundo Delumeau, "a criação dos asilos gerais (onde pobres e loucos encontraram-se frequentemente misturados), dos Zuchthäusern e das Workhouses é para nós reveladora de um vasto desígnio de enquadramento de uma sociedade que, por seus feiticeiros, seus heréticos, seus vagabundos e seus loucos, mas também por suas festas "pagãs" e suas blasfêmias repetidas, evadia-se constantemente fora das normas prescritas. Um processo geral de cristianização, de moralização e de unificação, desmedidamente ampliado a partir das duas Reformas, tendeu a disciplinar doravante populações que tinham vivido até então em uma espécie de liberdade 'selvagem'” (DELUMEAU, Jean, op. cit. p. 417).

${ }^{403}$ MELOSSI, Dario; PAVARINI, Massimo, op. cit. p. 47. 
em força de trabalho. Sendo assim, o funcionamento destas instituições implica em uma disciplina geral da existência que ultrapassa amplamente as suas finalidades aparentemente precisas. A imoralidade, principalmente a sexual, trouxe problema considerável para os patrões das fábricas do começo do século XIX, menos em função dos problemas de natalidade, que se controlava mal, e mais devido ao fato de o patronato não suportar a devassidão e a sexualidade operárias. ${ }^{404}$

A ética puritana empobrecia o operário ao assumir uma postura desconfiada e de muitas maneiras hostil em relação aos bens culturais cujos valores não eram diretamente religiosos ou científicos. Repudiava as festas, superstições e jogos. O teatro era visto como uma ostentação vã, um comportamento irracional, sem finalidade e não ascético. ${ }^{405}$ Segundo Becker, três valores legitimavam a repressão do uso de álcool e ópio nos EUA, já no século XX. A ética protestante afirma que o indivíduo deveria exercer completa responsabilidade pelo que faz e pelo que lhe acontece e nunca deveria fazer nada que pudesse causar a perda do autocontrole. Por outro lado, a cultura do pragmatismo e utilitarismo condena as ações empreendidas com o único intuito de alcançar estados de êxtase, os chamados "prazeres ilícitos". Por fim, o humanitarismo diz que pessoas escravizadas pelo uso de álcool e ópio, bem como suas famílias, se beneficiariam de leis que tornassem impossível para elas ceder à sua fraqueza. ${ }^{406}$

$\mathrm{Na}$ sociedade moderna industrial do século XIX, era preciso que o tempo dos homens, não apenas o tempo do seu dia de trabalho mas o da sua vida inteira, fosse oferecido ao aparelho de produção. E ainda que o tempo das pessoas não fosse extraído em sua totalidade, devia ser controlado para tornar-se tempo de trabalho. Uma série de medidas foi adotada visando suprimir as festas e diminuir o tempo de descanso. Por outro lado, a economia dos operários deveria ser controlada através de caixas econômicas e caixas de assistência para que, quando desempregados, não morressem de fome antes de recomeçar a trabalhar e para que, quando empregados, não utilizassem suas economias para fazer greve, festejar ou jogar. ${ }^{407}$

Foucault aponta a existência de mecanismos extrajudiciais de controle permanente do comportamento dos indivíduos que se formaram obscuramente durante o século XVIII para responder a certo número de necessidades e, assumindo cada vez maior importância,

\footnotetext{
${ }^{404}$ FOUCAULT, Michel. A verdade e as formas jurídicas. Rio de Janeiro: Nau, 1996.p. 116 et seq.

${ }^{405}$ WEBER, Max, op. cit. p. 152 et seq.

${ }^{406}$ BECKER, Howard, op. cit. p. 142-143.

${ }^{407}$ Cf. FOUCAULT, Michel, Vigiar e punir. 28 ed. Petrópolis: Editora Vozes, 2004. p. 149.
} 
se estenderam finalmente por toda a sociedade e se impuseram a uma prática penal. Assim, na Inglaterra, desde a segunda metade do século XVIII formaram-se, em níveis relativamente baixos da escala social, grupos espontâneos de pessoas de inspiração religiosa quaker e metodista que se atribuíam, sem a delegação de um poder superior, a tarefa de criar, para eles próprios, novos instrumentos que assegurassem a ordem. A esses grupos eram submetidos todos os casos de embriaguez, adultério, recusa de trabalho, etc.

Em 1692, fundou-se na Inglaterra a Sociedade para a Reforma das Maneiras, uma sociedade aparentada às comunidades propriamente religiosas que se propunha a respeitar o domingo, impedir o jogo, a bebedeira, reprimir a prostituição, o adultério, as imprecações, as blasfêmias, tudo o que pudesse manifestar desprezo para com Deus. Em 1802 é criada a Sociedade para a Supressão do Vício, de composição mais aristocrática, tendo por objetivo fazer respeitar o domingo, impedir a circulação dos livros licenciosos e obscenos, introduzir ações na justiça contra a má literatura e mandar fechar as casas de jogo e de prostituição. Esta sociedade, ainda que de funcionamento essencialmente moral, próxima dos grupos religiosos, já era, entretanto, um pouco laicizada.

No início, quando estes grupos eram quase populares, na pequena burguesia, a vontade de fazer reinar a ordem era, no fundo, uma forma de escapar ao poder político estatal e evitar qualquer pretexto para a utilização de sua sanguinária e aterrorizadora legislação penal. Tratava-se, portanto, mais de grupos de autodefesa contra o direito do que de grupos de vigilância efetiva. No entanto, quando os grupos de autodefesa moral passam a ser comandados pela aristocracia, bispos, duques e por pessoas mais ricas, o empreendimento de reforma moral deixa de ser uma autodefesa penal para se tornar, ao contrário, um reforço do poder da própria autoridade penal. Verifica-se uma verdadeira estatização dos grupos de controle.

Enquanto os primeiros grupos almejavam fazer reinar uma ordem moral diferente da lei, que permitisse aos indivíduos escapar dela, os grupos controlados pela aristocracia e pelas pessoas ricas tinham como objetivo obter do poder político novas leis que ratificassem esse esforço moral, ou seja, há um deslocamento da moralidade à penalidade. Introduz-se e difunde-se em um sistema penal estatizado, que ignorava por definição a moral e pretendia cortar os laços com a moralidade e a religião, justamente uma 
moralidade de origem religiosa. Esse controle moral torna-se, assim, um instrumento de poder das classes ricas sobre as classes pobres. ${ }^{408}$

Ao analisar os períodos de maior repressão política que se seguiram aos processos revolucionários na Inglaterra de 1640, na França de 1789 e na Rússia de 1917, Crane Brinton observa que em cada um deles a classe dirigente pareceu ter desejado impor à vida na Terra parte da ordem, disciplina e desprezo pelos vícios fáceis que foram os objetos dos calvinistas, em um verdadeiro "reinado de terror e virtude". Assim, durante o governo jacobino na França, houve uma tentativa vigorosa de limpar Paris, fechar casas de tolerância, antros de jogo e acabar com a embriaguez. Da mesma maneira, durante o processo revolucionário russo, os bolcheviques proibiram a vodca, e quase todos os primeiros sovietes tomaram providências contra a prostituição, o jogo e a vida noturna, não sendo permitida a publicação de fotografias de mulheres seminuas ou referência à pornografia na literatura ou em qualquer outra forma de arte. ${ }^{409}$

Já na era do neoliberalismo, a pobreza é encarada como responsabilidade e produto de carências individuais dos pobres, como falta de capacidade cognitiva, de valores morais ou inferioridade racial. ${ }^{410}$ Mediante uma engenhosa campanha de estigmatização e demonização dos beneficiários de programas sociais, busca-se associar a pobreza à criminalidade e convencer o eleitorado de que, além de extremamente dispendiosas, tais verbas são ilegítimas, uma vez que beneficiariam pais irresponsáveis, mães solteiras e demais parasitas sociais, responsáveis eles mesmos por sua precariedade. ${ }^{411}$

\footnotetext{
${ }^{408}$ FOUCAULT, Michel. A verdade e as formas jurídicas. Rio de Janeiro: Nau, 1996. p. 89 et seq. Salienta, por sua vez, Delumeau: "Embora a legislação civil tenha continuado a tolerar em vários países as fogueiras de São João e o carnaval (ao qual a Igreja tridentina tentou opor as "Quarenta Horas"), no entanto, a partir do século XVI poder eclesiástico e poder civil apoiaram-se mutuamente para melhor vigiar a conduta religiosa e moral das populações. Na França, por exemplo, ordenações severas e repetidas, seguindo as de Orleans (1560) e de Blois (1579), fazem do rei mais do que nunca o protetor da Igreja. A realeza se empenha inteiramente em "estender a mão" à religião. Legisla sobre a interdição das atividades servis e mecânicas aos domingos e festas obrigatórias, fazendo transferir para o dia seguinte as feiras e mercados. Zela pelo fechamento dos cabarés durante os ofícios; para que nesse momento não se jogue boliche ou péla; para que ajuntamentos indiscretos não se sigam à missa na praça da igreja ou no cemitério. Combate as danças públicas, os jogos de azar, os banquetes de confrarias, as festas dos padroeiros demasiadamente ruidosas, as devoções suspeitas. Vigia as "recreações perigosas" e censura o teatro. Apoia os bispos que procuram diminuir os dias feriados- ocasiões de escândalos e de bebedeiras. Impõe uma ordem às procissões. E, finalmente, a partir de Luís XIV, submete à autorização as peregrinações ao estrangeiro, pretextos de vagabundagem, de desordens, da fuga para fora do reino da mão-de-obra e do dinheiro." (DELUMEAU, Jean, op. cit. p. 411).

${ }^{409}$ BRINTON, Crane. Anatomia das revoluções. Rio de Janeiro: Fundo de Cultura, 1958. p. 208 et seq.

${ }^{410}$ FEELEY, Malcolm; SIMON, Jonathan. The new penology: notes on the emerging strategy of corrections and its implications. Criminology 30-4, novembro, p. 468.

${ }^{411}$ BARATTA, Alessandro, op. cit. p. 195.
} 
Ganha cada vez mais terreno a ideia de que não seria a estagnação da renda média familiar, a baixa do salário mínimo, a erosão da cobertura social e médica e o desemprego, os grandes responsáveis pela escalada da pobreza nos EUA, mas justamente a excessiva generosidade das políticas de ajuda aos mais pobres, na medida em que recompensaria a inatividade e induziria a degenerescência moral das classes populares. ${ }^{412}$ As classes médias, adeptas da ética do trabalho, sentem-se duplamente provocadas quando as verbas sociais, pagas por elas com seus impostos e concedidas a um "parasita negro" que prefere receber um salário desemprego a se submeter a um trabalho desagradável ganhando quase a mesma coisa, e gastadas supostamente em drogas e prostituição (e por que não, em baile funk, no Brasil?). ${ }^{413}$

O neopositivismo conservador, deslocando a causalidade do nível social para o individual, ignorando os motivos que levam uma pessoa a delinquir, bem como a opressão que pode se ocultar em uma família tradicional mantida a qualquer custo, vê na família monoparental a origem do crime, na medida em que não estaria apta a socializar a criança nos seus primeiros anos, assim como controlar seus impulsos. ${ }^{414}$ Theodore Chiricos e Miriam Delone realçam o pensamento de Dario Melossi, segundo o qual em períodos de recessão econômica emerge uma nova "moralidade" punitiva que visa particularmente os desempregados, pois são vistos pelos juízes como criminosos potenciais, que devem ser duramente intimidados. ${ }^{415}$

De acordo com Nils Christie, em uma sociedade urbana mais complexa e plural, em que os indivíduos ganham anonimato, aumenta a distância social e, consequentemente, a tendência a atribuir a certos atos o significado de crimes e às pessoas o atributo de criminosas. Não se conhece mais o contexto no qual a conduta foi praticada, a história de vida do infrator e suas qualidades positivas, o que favorece sua demonização. ${ }^{416} \mathrm{O}$ DJ Marlboro sustenta que o funk vence preconceitos atravessando gerações. Os pais que foram frequentadores de baile funk deixam seus filhos frequentá-lo sem medo, porque

\footnotetext{
${ }^{412}$ WACQUANT, Loïc. As prisões da miséria. Rio de Janeiro: Jorge Zahar, 2001. p. 22. Nesta visão, o Estado deve ser um tutor moral inflexível, para, mediante a disciplina do trabalho, libertar os pobres de sua "passividade" (Ibid. p. 45).

${ }^{413}$ CHRISTIE, Nils. A indústria do controle do crime. Rio de Janeiro: Forense, 1998. p. 59.

414 YOUNG, Jock. A sociedade excludente: exclusão social, criminalidade e diferença da modernidade recente. p. 88.

${ }^{415}$ CHIRICOS, Theodore G.; DELONE, Miriam A. Labor surplus and punishment: a review and assessment of theory and evidence. Criminology, vol. 29,14, 1991. p. 424-425.

${ }^{416}$ CHRISTIE, Nils, op. cit. p. 13-14.
} 
conhecem o baile e sabem que existem muitos exageros nas campanhas que tentam denegrir ou acabar com o funk. ${ }^{417}$

Os traficantes são pessoas da comunidade, cujos nomes, familiares e histórias de vida são conhecidos pelos demais moradores. Talvez por isso os "trabalhadores" tendam a ter um discurso ambíguo em que o chefe do tráfico, por um lado, é mencionado como protetor e ajudado quando, por exemplo, precisa de esconderijo, e, por outro lado, é visto como vagabundo ou bandido opressor que impõe, entre outras, a lei do silêncio. ${ }^{418}$ Setores da classe média, por sua vez, ao ver que seus filhos passaram a frequentar os bailes funk de comunidade, relativizaram sua visão criminalizante do fenômeno. Afinal, seus filhos não tinham nada a ver com aqueles "bandidos". Eram, quando muito, adolescentes vivendo nos bailes a fase de rebeldia desculpável da idade. ${ }^{419}$ Alguns pais de classe média acompanhavam seus filhos e filhas para observar o ambiente:

\begin{abstract}
As visitas no morro, nos dias de baile, e as histórias contadas nos raps dos MCs, fazem com que a realidade da juventude das favelas chegue à juventude de outros bairros. A proximidade dilui o medo e um certo nível de identificação reacende esquecidos sentimentos de solidariedade. A garotada de classe média está pulando o muro e fazendo o que as gerações mais velhas não vinham conseguindo fazer: construir as bases da restauração da cultura da solidariedade e da cordialidade, entre "as duas cidades". ${ }^{220}$
\end{abstract}

Enquanto os "funkeiros" eram condenados por invadirem as praias da Zona Sul nos fins de semana, nesses mesmos fins de semana ocorria uma "invasão" no sentido inverso. O baile de comunidade exerceu o papel de "zona de contato" entre segmentos sociais diversos, fazendo com que jovens de classe média e alta conhecessem a favela e desnaturalizassem a ideia de que ela é um "território necessariamente marcado pela violência e pelo medo". Talvez o principal "ato político" operado pelo funk tenha sido esta aproximação, ainda que apenas no plano simbólico, entre jovens de diferentes classes sociais, o que não aplaca, contudo, os efeitos de uma estrutura social excludente. ${ }^{421}$

${ }^{417}$ SALLES, Lúcia (Org.). DJ Marlboro: o funk no Brasil - por ele mesmo. Rio de Janeiro: Mauad, 1996. p. 40-41.

${ }^{418}$ MINAYO, Maria Cecília de Souza et alii. Fala, galera: juventude, violência e cidadania no Rio de Janeiro. Rio de Janeiro: Garamond, 1999. p. 159-160.

${ }^{419}$ ESSINGER, Silvio. Batidão: uma história do funk. Rio de Janeiro: Record, 2005. p. 134.

${ }^{420}$ RIBEIRO, Manoel. "Funk'n Rio: vilão ou big business?" In: Revista do Patrimônio Histórico e Artístico Nacional, n. 24. Ministério da Cultura, IPHAN, 1996. p. 290.

${ }^{421}$ HERSCHMANN, Micael. O funk e o hip hop invadem a cena. Rio de Janeiro: Editora UFRJ, 2000. p. 236-239. O exotismo das letras, dotado de uma certa comicidade, e principalmente a batida forte da música parecem ser o que move jovens de classe média e alta a ouvir e dançar o funk, muito mais do que o desejo de integração social. O consumo do funk carioca "não produz necessariamente alterações na forma como jovens 
Setores conservadores, por outro lado, consideraram perigosa essa aproximação de classes, essa "promiscuidade" entre segmentos sociais e exigiram o fechamento dos bailes pela polícia. ${ }^{422}$ É justamente quando o funk sai de seu locus natural, no episódio do arrastão de 1992, que a exigência de medidas repressivas em relação aos bailes torna-se mais frequente. A recepção das classes médias e altas ao funk carioca foi ambígua, pois o exótico, ao mesmo tempo em que assusta, seduz. A sociedade se incomodava em ver "galeras" de jovens suburbanos e favelados instalando o caos nas areias frequentadas pela classe média e alta. Contudo, se incomodava ainda mais com a adesão de parte da juventude destas classes sociais a esse tipo de música e festa, o que teria motivado de fato a interdição dos bailes de comunidade. ${ }^{423}$

De acordo com Hermano Vianna, os jovens de diferentes classes sociais ficariam separados e desconhecendo "se a realidade social não fosse muito mais complexa e surpreendente do que mandam as cartilhas de um certo planejamento urbano multicultural". As novas mediações são criadas a todo instante, onde menos se espera. $\mathrm{O}$ programa da Xuxa, por exemplo, foi fundamental na década de 90, época da demonização do funk pela mídia, para torná-lo popular entre crianças moradoras de condomínios da Zona Sul carioca. Nem a mídia, nem a elite, nem os funkeiros são entidades homogêneas. "O exótico pode viver dentro do quarto de nossos familiares, bem ao lado de nossos próprios quartos". 424

Jock Young tem a visão de que o mundo da modernidade recente, apresentando uma pluralidade imensa de valores, não facilita a criação de demônios populares. É difícil

das classes médias e altas constroem suas visões sobre jovens favelados nem modifica as dinâmicas de segregação espacial e as formas de sociabilidade, ao menos no tocante às atividades de entretenimento e lazer". Arthur Coelho Bezerra invoca sua pesquisa empírica em um baile funk do Circo Voador, na Lapa, para questionar o "potencial integrador" do funk. O valor da entrada era de 40 reais, 20 reais para estudantes, o refrigerante custava três reais, quatro reais a cerveja e o táxi era o meio de transporte predileto, enquanto nos bailes funk de comunidade, a entrada geralmente é gratuita e o preço da cerveja não costuma ser superior a dois reais. Os jovens entrevistados, em abril de 2007, manifestaram medo de frequentar bailes de comunidade e de relacionar-se afetivamente com um morador de comunidade pobre, ainda que fosse admitida a possibilidade de só "ficar" com um deles (BEZERRA, Arthur Coelho. Apontamentos sobre o consumo de funk carioca pelas elites urbanas. XIII Congresso Brasileiro de Sociologia. 2007, UFPE. p. 911). De qualquer forma, é bastante emblemático que a música que faz "apologia á favela", antes confinada territorialmente, tenha penetrado as fronteiras supostamente invioláveis dos enclaves fortificados de lazer e que os MCs se desloquem por diversas áreas da cidade, percorrendo o circuito do funk e cantando em pedaços nos quais quem é "de fora" tem dificuldade de ingressar.

${ }^{422}$ HERSCHMANN, Micael, op. cit. p. 103, 172.

${ }^{423}$ ESSINGER, Silvio, op. cit. p. 135. Os relatos de brigas dentro dos bailes, e arrastões nas saídas deles sempre foram tratados como uma barbárie distante, sem provocar reações de indignação, até os filhos da classe média começarem a consumir o funk (MEDEIROS, Janaína. Funk carioca: crime ou cultura?: o som dá medo: e prazer. São Paulo: Editora Terceiro Nome, 2006. p. 19-20).

424 VIANNA, Hermano. O funk como símbolo da violência carioca. In: VELHO, Gilberto; ALVITO, Marcos. Cidadania e violência. Rio de Janeiro: UFRJ/FGV, 1996. p. 185-186. 
criar a noção de outro desviante em um mundo precário no qual todos têm contato próximo com um desempregado ou uma mãe solteira, onde a criminalidade é percebida em todas as camadas sociais e o agressor muitas vezes é um familiar ou amigo próximo. Os pânicos morais, uma resposta ao colapso da hegemonia cultural, são cada vez mais banalizados e contestados. Entretanto, as ideias tornam-se mais necessárias precisamente no momento em que se tornam menos plausíveis. ${ }^{425}$ Apesar de as causas da criminalidade serem disseminadas demais para serem atribuídas a um só grupo, o estereótipo de criminoso é generalizado a partir de uma amostragem escolhida pelo sistema de justiça criminal. ${ }^{426}$

Glamorização e criminalização são duas faces da mesma moeda. Nos momentos em que o funk torna-se mais popular, fazendo sucesso junto a juventude de classe média e alta, que ele se torna mais ameaçador e é mais duramente reprimido. Por sua vez, quanto mais reprimido, mais glamorizado ele é. Se há a necessidade de nomear e a tendência de demonizar o desconhecido e o exótico, por outro lado, à medida que o "outro" se integra culturalmente e se torna mais parecido e próximo, paradoxalmente surge de forma mais forte a necessidade de restabelecer o quadriculamento social, as diferenças, distâncias e divisões. As pessoas, com medo, tornam-se excludentes e preocupam-se em manter o “outro" à distância, desenhando fronteiras novas e fortes, aptas a garantir a homogeneidade cultural.

Os avanços dos movimentos negro, feminista e a maior integração de imigrantes causam na modernidade recente uma verdadeira crise de identidade, uma insegurança ontológica que resulta em tentativas repetidas de criar uma base segura, reafirmar valores como absolutos morais, declarar que outros grupos não têm valores, estabelecer limites distintos em relação ao que é virtude ou vício, ser rígido em vez de flexível ao julgar, ser punitivo e excludente em vez de permeável e assimilativo. O mote das campanhas é a "volta aos valores da família". 427

\footnotetext{
${ }^{425}$ YOUNG, Jock, op. cit. p. 47 et seq.

${ }^{426}$ Ibid. p. 72.

${ }^{427}$ Ibid p. 34, 47 et seq. É esse movimento que pode explicar a busca das classes médias e altas por novas formas de segregação em resposta aos avanços dos movimentos sociais após a abertura política (Cidade de Muros: crime, segregação e cidadania em São Paulo. São Paulo: Editora 34/Edusp, 2000. p. 327). Henrique Antoun afirma que a rejeição atual ao funk se baseia na "mentalidade da classe média (...). Os pais ficam apavorados porque a filha pode aparecer agarrada com um negro, cantando au, au" (Apud CECCHETTO, Fátima; FARIAS, Patrícia. Do funk bandido ao pornofunk: o vaivém da sociabilidade juvenil carioca. In: Interseções: Revista de Estudos Interdisciplinares, ano 4, número 2. Rio de Janeiro: PPGCS/UERJ, 2002. p. 62). Segundo o DJ Marlboro, “o melhor momento do funk é quando ele não está na mídia. Quando ele vai para a mídia, ele traz mais problemas do que soluções” (Apud ESSINGER, Silvio, op. cit. p. 213, 214).
} 


\subsection{O componente subversivo da diversão}

Enquanto o rap é um estilo de vida mais politizado, que interfere de forma mais decisiva na identidade dos jovens que a ele aderem, prescrevendo valores e comportamentos, o funk constitui "um estilo de vida fluido e com interferência limitada nas outras esferas da vida dos jovens". Por intermédio do funk, os jovens ressaltam a festa, a fruição do prazer, a alegria de estarem juntos, dimensões importantes da condição juvenil, quase sempre negadas no cotidiano desses jovens. ${ }^{428}$

Ao contrário do rap, a produção musical dos funkeiros não tem muito sentido em si mesma, a não ser divertir, animar os bailes, e é efêmera, sem maiores preocupações com a qualidade musical, abordando, muitas vezes de forma jocosa, temas diretamente ligados ao universo das vivências juvenis, como amor, sexo, amigos, o baile e as galeras, demonstrando não só um desejo de reconhecimento e de reinscrição do seu mundo na cidade, mas de vivenciarem a própria condição juvenil e "resgatar o prazer e o humor negados em um cotidiano dominado pela lógica instrumental dominante". ${ }^{429}$

O individualismo e o utilitarismo da vida cotidiana, ditados pela "produção econômica e o crescimento industrial" se opõem ao ludismo, à inutilidade, ao êxtase, à imoderação, à demência, à irresponsabilidade e ao holismo da festa, tão necessários para estruturar e regenerar a sociedade. ${ }^{430}$ A festa é a concretização do ideal, de alguns desses jovens, de felicidade humana, embaraça o limite que separa o lícito do ilícito, e condena a "vida séria" cotidiana, o tédio, a tristeza, uma organização "repressiva" da sociedade, as incontáveis regras e hierarquias, que, a despeito do princípio da individuação, não deixam as pessoas expressarem sua individualidade. ${ }^{431}$

Vianna aponta que nos bailes nenhuma regra social é contestada e não existe nenhuma inversão de papéis ou valores, como dizem haver no carnaval. A liberalidade sexual que se vê nos bailes não é nenhuma transgressão, estando presente na publicidade no horário nobre da televisão. Sendo puro gasto de energia, a festa pode contrariar o

\footnotetext{
${ }^{428}$ DAYRELL, Juarez. A música entra em cena: o rap e o funk na socialização da juventude. Belo Horizonte: Editora UFMG, 2005. p. 123, 146.

${ }^{429}$ Ibid. p. 165-167.

${ }^{430}$ VIANNA, Hermano. O mundo funk carioca. 2 ed. Rio de Janeiro: Zahar, 1988. p. 56. De acordo com Bakhtine, no carnaval, ao contrário do que ocorre nas festas oficiais, encontra-se "a abolição provisória de todas as relações hierárquicas, privilégios, regras e tabus" e entra-se temporariamente no reino da liberdade, da universalidade, da igualdade e da abundância, abrindo espaço para a renovação da vida social (Apud Ibid. p. 57).

${ }^{431}$ VIANNA, Hermano, op. cit. p. 100.
} 
“espírito do capitalismo", mas o espírito do capitalismo tem várias faces e em alguns momentos pode até incentivar ataques contra sua "vida séria". O divertimento e a rápida fuga das obrigações cotidianas podem servir, assim como a religião, para reabastecer a sociedade de energia para voltar com mais ardor à "vida séria". A festa, no entanto, não tem nenhuma função, ainda que "tranquilizante", ou um sentido, e esse seria o seu grande poder sedutor. $^{432}$

Parece mais plausível, por se tratar de uma manifestação subcultural, sustentar que no baile funk, ainda que não propositadamente, alguns valores da sociedade mais ampla são reproduzidos, ainda que com o sinal invertido e outros questionados. A visão negativa em relação às drogas remonta aos hippies, que, ao contestarem os valores sociais, mostravam as imperfeições de uma sociedade aparentemente perfeita. ${ }^{433} \mathrm{O}$ consumo de drogas, no entanto, deixa de ser contracultural, sendo apropriado por uma indústria bastante lucrativa e articulada com o poder econômico e político, conforme observado no capítulo anterior.

O funk apropria-se e é apropriado por diversos grupos sociais e pela indústria cultural em geral. É uma manifestação cultural híbrida, que reproduz as "modalidades oficiais" e "subversivas" ao mesmo tempo. ${ }^{434}$ Por sua exclusão e inclusão, os funkeiros parecem cultivar uma sofisticada capacidade de ambiguidade, justaposição e ironia. Considerando-se os arrastões e os "proibidões", conclui-se que esta expressão cultural juvenil está em oposição clássica à estrutura social. Por outro lado, levando-se em conta o conjunto de elementos que caracterizam o estilo de vida funk, como o vestuário e os espaços onde se realizam os bailes, verifica-se que ele comporta também a negociação, apropriando-se de elementos canonizados nas culturas hegemônicas, até para garantir visibilidade, espaço no mercado e resistir. ${ }^{435}$

O baile funk não é um fenômeno antimeios de comunicação de massa ou algo do gênero. A festa não é propriedade de determinado grupo social, não é "privilégio de classe" nem ritual para escamotear as diferenças que existem dentro da sociedade. A pobreza dos dançarinos não aniquila a alegria de viver, aqui e agora, não importa o motivo, requisito

\footnotetext{
${ }^{432}$ VIANNA, Hermano, op. cit. p. 51-52, 68, 106. "A despeito do estereótipo de '́delinquente` associado ao funk, somente para uma minoria deles- que se auto-intitulam 'revoltados'- 'ser funkeiro' quer dizer um estilo que reflete a 'exclusão social' ou até a oposição à ordem constituída" (SANSONE, Livio. Funk baiano: uma versão local de um fenômeno global? In: HERSCHMANN, Micael (Org.). Abalando os anos 90: funk e hip hop: globalização, violência e estilo cultural. Rio de Janeiro: Rocco, 1997. p. 173-174).

${ }^{433}$ CHRISTIE, Nils, op. cit. p. 59-60.

${ }^{43}$ HERSCHMANN, Micael, op. cit. p. 71.

435 Ibid p. 214-215.
} 
fundamental para a festa ter graça. ${ }^{436}$ Para a cineasta Denise Garcia, as pessoas criticam as funkeiras por medo, pois "se fossem umas meninas loirinhas do Leblon cantando as mesmas coisas, elas seriam as nossas Spice Girls”. Cobradas por não serem supostamente “politizadas", elas não querem cantar, ouvir e dançar no fim de semana as mazelas sociais que vivem no seu dia a dia e sim se divertir, mas "o problema é que a diversão é uma coisa extremamente revolucionária". 437

No Brasil o Direito Penal sempre exerceu uma função muito mais de controle das classes baixas e reafirmação da ordem hierárquica. A sociedade disciplinar, tal qual descrita por Foucault, nunca foi implementada, em virtude da própria estrutura social do escravismo, em que a vontade circunstancial e a ordem do senhor tinham maior relevo que a norma impessoal liberal ${ }^{438}$. No entanto, contravenções penais como a vadiagem e referentes à paz pública e à polícia de costumes foram amplamente utilizadas para reforçar a ética do trabalho e controlar uma população perigosa, a mesma que é controlada nos dias atuais pelos tipos penais de tráfico de drogas, apologia ao crime e corrupção de menores.

\subsection{O medo de aglomerações negras}

Eu vou bebê,

Eu vou me embriagá,

Eu vou faze baruio

Pra puliça me pegá.

A puliça não qué

Que eu dance aqui,

Eu danço aqui,

Danço acolá.

(Canto popular de desafio aos guardas-civis) ${ }^{439}$

\footnotetext{
436 VIANNA, Hermano, op.cit. p. 110.

${ }^{437}$ Apud MEDEIROS, Janaína, op. cit. p. 84.

438 Cf. KOERNER, Andrei. O impossível "panóptico tropical-escravista": práticas prisionais, política e sociedade no Brasil do século XIX. In: Revista Brasileira de Ciências Criminais, nº 35, jul/set 2001. p. 212 et seq.

${ }^{439}$ CHALHOUB, Sidney. Medo branco de almas negras: escravos libertos e republicanos na cidade do Rio. In: Discursos Sediciosos: crime, direito e sociedade, ano 1, nº 1. Rio de Janeiro: Relume Dumará, 1996. p. 186.
} 
"Crioulo cantando samba era coisa feia

Esse negro é vagabundo, joga ele na cadeia

Hoje o branco tá no samba quero ver como é que fica

Todo mundo bate palmas

Quando ele toca cuíca

Negro jogando pernada, negro jogando rasteira

Todo mundo condenava uma simples brincadeira

E o negro deixou de tudo, acreditou na besteira

Hoje só tem gente branca na escola de capoeira"

("Vá cuidar da sua vida", de Geraldo Filme)

A repressão policial ao lazer de populações negras no Brasil não é novidade do fim do século XX. O Livro $\mathrm{V}$ das Ordenações Filipinas já proibia os bailes de escravos. O Código Criminal de 1830, por sua vez, criou o crime de insurreição, punia a propaganda da insurreição, punia a celebração, propaganda ou culto de confissão religiosa que não fosse a oficial, criminalizou a vadiagem e a mendicância. ${ }^{440}$

Em 1835, ano da revolta dos escravos malês, na Bahia, havia a suspeita e temor de que os escravos das províncias do Rio de Janeiro e de Minas Gerais "queriam tentar um movimento insurrecional". As autoridades policiais receberam ordens no sentido de "dissolver qualquer ajuntamento de escravos e prender os que nele se encontrarem". Afinal, a cidade codificada e desejada pelos brancos se opunha à cidade-esconderijo instituída pelos negros, na qual a condição social era escondida, dificultando a distinção entre escravos, libertos e pretos livres. Todos negros, portanto, eram alvo de suspeição generalizada.

Os administradores da cidade tentaram em vão codificá-la, discipliná-la e evitar que ela se transformasse num esconderijo. O Código de Posturas de 1830 proibia que os donos de casas de negócio consentissem na presença “em suas portas (de) pessoas cativas sentadas, ou a jogarem, ou paradas por mais tempo do que necessário para fazerem as compras". O Código de Posturas de 1838 recomenda aos donos das tavernas que não permitam o "ajuntamento de mais de quatro escravos", e estabelece que "todo o escravo

${ }^{440}$ SILVA JR., Hédio. Direito Penal em preto e branco. In: Revista Brasileira de Ciências Criminais, ano 7 , n. 27, jul/set 1999. p. 328-329. 
que for encontrado das sete horas da tarde em diante, sem escrito de seu senhor, datado do mesmo dia, no qual declare o fim a que vai, sofrerá oito dias de prisão, dando-se parte ao senhor”. Há vários registros, porém, inclusive policiais, de negros escravos circulando livremente pelas ruas à noite ou permanecendo longo tempo em quiosques ou botequins. ${ }^{441}$

O Código Criminal do Império, de 1830, é promulgado na esteira do medo de insurreições, "nas expectativas de que à nação independente de 1822 sobreviessem os direitos plenos de seu povo mestiço, na radicalização do liberalismo e dos sonhos de República". A circulação e movimentação dos escravos e pretos forros eram consideradas ameaçadoras. Segundo Vera Malaguti Batista, ecoam ainda na sociedade "sinais do absolutismo na sua indiferenciação entre religião, moral e princípios jurídicos”. A polícia intervém para garantir a segurança nos muitos casos em que a situação jurídica não está clara. Muito mais do que a legalidade, ela garante a ordem e disciplina, enfrenta o ambiente das revoltas da primeira metade do século XIX e atua basicamente nas ofensas à ordem pública: vadiagem, mendicância, embriaguez, capoeiras, "incômodos que a ordem burguesa industrial trataria de criminalizar".

O sistema penal controlava escravos, africanos livres, pobres sem patrão, ciganos, mendigos, vadios e crianças abandonadas para que as ruas da cidade pudessem servir às crescentes atividades do comércio e da indústria. Contra as formas de resistência da população recrudescem as detenções por comportamentos ilegais e inaceitáveis. Em 1850 as prisões permaneciam superlotadas de pobres e escravos $(65 \%$ das detenções eram por ofensas à ordem pública e não por crimes). ${ }^{442}$

O artigo 22 da Postura da Câmara Municipal da Vila do Prado, tutelando a dedicação da força de trabalho servil às tarefas assinadas pelos senhores, punia com multa ou quatro dias de prisão os donos de tendas, botequins ou tavernas que "permitissem em seus estabelecimentos a demora de escravos por mais tempo que o necessário para as compras". Na Vila de Joazeiro, os lundus, batuques e algazarras eram punidos com um dia de prisão. $^{443}$

Em 1848, facas e navalhas eram instrumentos comuns de utilização entre os capoeiras da província do Grão-Pará, alimentando um crescente medo, por parte dos proprietários de escravos e administradores públicos, de que os escravos se articulassem

${ }^{441}$ CHALHOUB, Sidney, op. cit. p. 172 et seq.

${ }^{442}$ BATISTA, Vera Malaguti. A arquitetura do medo. In: Discursos Sediciosos, ano 7, n. 12, 2002. p. 100 et seq.

${ }^{443}$ ZAFFARONI, E. Raúl; BATISTA, Nilo; ALAGIA, Alejandro; SLOKAR, Alejandro. Direito Penal brasileiro: primeiro volume-Teoria Geral do Direito Penal. 3 ed. Rio de Janeiro: Revan, 2006. p. 425-426. 
em uma grande rebelião e tomassem o poder na região. Alguns órgãos de notícia apontavam os capoeiras como "vagabundos, livres ou cativos, dados à crápula", elementos perniciosos para a manutenção da "ordem pública". O termo "capoeira" carregava um sentido pejorativo, significando muitas vezes a reunião de escravos, e mesmo negros livres, para beberem e jogarem com pernas, braços e cabeças, armados de "paus e pedras que em grande assoada" se dividiam "em dois campos inimigos", e gastavam "horas esquecidas nesse exercício".

Desta forma, um possível conflito entre grupos de capoeiras, as maltas, além de causar prejuízo à tranquilidade pública, traziam problemas para seus senhores por eles desperdiçarem "horas esquecidas" na capoeiragem. Os capoeiras também eram responsabilizados por "arrombamentos de portas e mesmo roubos" ocorridos pela cidade. No entanto, a preocupação maior expressa nos jornais da época não era com a punição dos capoeiras, mas com a proibição de qualquer manifestação que favorecesse o ajuntamento de escravos, apontado como pernicioso para a segurança pública.

Muitas práticas de rua seriam controladas e outras até mesmo quase extintas em nome do combate aos "crimes contra a polícia e a economia dos municípios". Quatro artigos do Código de Posturas Municipais de 1848 se referiam diretamente ou à reunião de escravos ou à possibilidade da participação de escravos em folguedos de rua. Pelo artigo 76 ficou proibida a ocorrência de "vozerias na rua ou mesmo em casa nas horas de silêncio". O artigo 82 dispunha que "os donos ou administradores de qualquer casa de venda, não consentirão aí o ajuntamento de mais de dois escravos, nem batuques ou vozerias deles dentro da casa, ou em frente dela".

Todas estas proibições, sob o pretexto de assegurar a "ordem pública", possivelmente refletiam o receio, por parte dos escravocratas, frente a uma possível rebelião de escravos, e mesmo de homens livres, a partir de suas aglomerações. Alguns jornais do período, porém, apresentavam o desrespeito ao Código de Postura em Belém e cobravam uma tomada de atitude dos responsáveis pela segurança pública contra a "algazarra" dos capoeiras, associados a vadios, vagabundos e desordeiros que bebem e jogam em plena noite, "em tempo de ociosidade", e causam "insultos ofensivos à moral pública". 444

\footnotetext{
${ }^{444}$ LEAL, Luiz Augusto Pinheiro. Vozerias, assuadas e capoeira em Belém (1848-1850). In: Discursos sediciosos: crime, direito e sociedade, ano 4, n. 7/8. Rio de Janeiro: Instituto Carioca de Criminologia, 1999. p. 245 et seq.
} 
Durante a Primeira República, o temor das classes dominantes em relação às multidões surgidas a partir da revolução industrial e do crescimento acelerado da cidade guiou em grande parte as diversas obras urbanísticas do poder público na cidade do Rio de Janeiro. Havia a ameaça das concentrações de pobres se desenvolverem em distúrbios. Fazia-se necessário delimitar os espaços, dividindo-os em regiões de trabalho, de residência e de prazer. A elite carioca, que se auto-imaginava ordeira, pacífica e amante da estabilidade social, procurou, diante do processo de aumento demográfico, expulsar do centro urbano parte substancial dos moradores, tidos como feios, sujos, malcheirosos, insalubres, violentos, desordeiros, baderneiros. Epidemias, carregadores descalços e sem camisa, ambulantes aos gritos, o odor de bacalhau e toucinho de fumeiro pendurados nos armazéns, capoeiras desafiando a ordem e glorificando a vadiagem eram resquícios do atraso colonial, enfim, a antítese da metrópole moderna e europeizada almejada.

Em agosto de 1904, o jornal O Paiz recomendava aos trabalhadores que não se levantassem contra as autoridades legalmente constituídas e a ordem social, que não buscassem sua ruína e miséria com meetings injustificados. Esses meetings poderiam “descambar para a rebelião, e esta levar a todos para as profundezas do penhasco, cujo resultado final seria a própria extinção da vida em sociedade”. A população deveria incorporar o dogma positivista de que a manutenção da ordem constituía elemento primordial para o progresso social. Caso a multidão não assimilasse o lema da bandeira nacional por bem, contestasse a ordem social e semeasse a desordem e a baderna, a elite apelava para a ação da polícia e do Exército, a fim de assegurar a estabilidade pública. ${ }^{445}$

Em São Paulo, no período de 1892 a 1916, com lacunas nos anos de 1899 a 1901, dentre 178.120 pessoas presas na cidade, 149.245 (83,8\%) foram detidas pela prática de contravenções ou para averiguações, revelando uma estrita preocupação com a ordem pública, aparentemente ameaçada por infratores das normas do trabalho, do bem-viver ou por "suspeitos". ${ }^{446}$ Boris Fausto interpreta a grande incidência proporcional das desordens nas prisões efetuadas entre 1892 e 1896 à presença em massa de novas levas de imigrantes na cidade. As novas formas de lazer introduzidas pelos imigrantes representavam "(a) quebra dos padrões do bom comportamento na ótica da 'sociedade respeitável' e de seus quadros dirigentes". Por outro lado, surgiam de fato muitos conflitos "entre gente apinhada

445 ALMEIDA, Adjovanes Thadeu Silva de. O olhar da elite sobre a multidão nas reformas urbanas da Primeira República. In: Discursos Sediciosos: crime, direito e sociedade, v. 9/10. Rio de Janeiro: Freitas Bastos, 2000. p. 285 et seq.

${ }^{446}$ FAUSTO, Boris. Crime e cotidiano: a criminalidade em São Paulo (1880-1924). 2. ed. São Paulo: EDUSP, 2001. p. 44. 
nos cortiços, precariamente liberada aos domingos das normas do trabalho", e as alegrias do domingo eram muitas vezes "a outra face das tensões a que estava submetida a população imigrante, na luta por adaptar-se e ascender socialmente na nova terra". ${ }^{47}$

No fim do século XIX, começavam a surgir no Brasil indústrias para substituir as importações e a ideologia positivista, característica de uma república militar autoritária, impunha uma atuação rigorosa do sistema penal. ${ }^{448}$ A burguesia industrial estava interessada na exploração de mão-de-obra de crianças e pressionava por uma legislação severa que garantisse a mão-de-obra barata. O artigo 30 do Código Penal de 1890 previa a pena de trabalhados forçados em estabelecimentos disciplinares industriais até os 17 anos de idade para pequenos delinquentes. A greve foi criminalizada pelo artigo 206.

Conforme dispôs o artigo 400, o réu do crime de vadiagem que quebrava o termo de tomar ocupação em 15 dias devia ser recolhido a "colônias penais que se fundarem em ilhas marítimas ou nas fronteiras do território nacional". Os maiores de 14 anos eram recolhidos em estabelecimentos disciplinares industriais, onde poderiam ser conservados até a idade de 21 anos, segundo o artigo 399, §2. De acordo com Nilo Batista,

\begin{abstract}
Quando alguém fala que o Brasil é "o país da impunidade", está generalizando indevidamente a histórica imunidade das classes dominantes. Para a grande maioria dos brasileiros a punição é um fato cotidiano. Essa punição permeia principalmente o uso estrutural do sistema penal para garantir a equação econômica. OU os brasileiros pobres são presos por vadiagem ou arranjem rápido um emprego e desfrutem do salário mínimo (punidos ou mal pagos). Depois que já estão trabalhando, nada de greves para discutir o salário, porque a polícia prende e arrebenta (punidos e mal pagos). ${ }^{449}$
\end{abstract}

Nina Rodrigues asseverava que "o negro crioulo conservou vivaz os instinctos brutaes do africano: é rixoso, violento nas suas impulsões sexuais, muito dado á embriaguez e esse fundo de caráter imprime o seu cunho na criminalidade colonial atual". ${ }^{450}$ A criminalização da vadiagem mereceu esfuziante aclamação por parte de Nina, como medida de combate à indolência da população mestiça, atribuída à "riqueza nativa do solo, que dispensa qualquer trabalho". ${ }^{451}$ Boris Fausto enxerga na criminalização da

\footnotetext{
447 FAUSTO, Boris. Crime e cotidiano: a criminalidade em São Paulo (1880-1924). 2. ed. São Paulo: EDUSP, 2001. p. 49.

${ }^{448}$ BATISTA, Nilo. Punidos e mal pagos: violência, justiça, segurança pública e direitos humanos no Brasil de hoje. Rio de Janeiro: Revan, 1990. p. 125-126.

449 Ibid. p. 38 et seq.

${ }^{450}$ RODRIGUES, Raimundo Nina. As raças humanas e a responsabilidade penal no Brasil. Rio de Janeiro: Guanabara, 1894. p. 124. Sobre a permanência dos postulados de matiz lombroso/rodrigueana na literatura jurídica penal contemporânea, cf. SILVA JR., Hédio, op. cit. p. 336.

${ }^{451}$ RODRIGUES, Raimundo Nina, op. cit. p. 141.
} 
vadiagem um "claro exemplo de criminalização de um comportamento com o propósito de reprimir uma camada social específica, discriminada pela cor".

Já a criminalização da capoeira estava ligada particularmente à conjuntura histórica do Rio de Janeiro do período imediatamente posterior à Abolição. Os capoeiras profissionais formavam organizações de escravos e libertos, ameaçadores e instrumentais para a elite branca. Eram definidos por Assis Cintra como capangas políticos, que viviam à custa dos cabos eleitorais ou como desordeiros e ladrões, que atacavam os transeuntes. Os amadores, por sua vez, eram "meninos bonitos avalentoados, filhos de gente rica e importante", gente como o Barão de Rio Branco e Floriano Peixoto, que praticavam capoeira por simples esporte. A polícia perseguiu tanto os profissionais como os amadores, mas o alvo principal da repressão foram os primeiros. ${ }^{452} \mathrm{O}$ degredo de capoeiras para Fernando de Noronha tentava exorcizar o medo de maltas de capoeiras e "desocupados dos balcões comerciais ou não admitidos na disciplina fabril". 453

Além da vadiagem, mendicância e capoeiragem, o Código Penal de 1890 criminalizou o charlatanismo, o curandeirismo e o espiritismo, visando às religiões afrobrasileiras. Os republicanos talvez tenham tido a intenção de transformar os pobres urbanos da cidade negra, arredia, solidária e alternativa em trabalhadores assalariados disciplinados, civilizados moralmente e higienizados. Reprimindo a vadiagem e opções indesejáveis de sobrevivência, os administradores republicanos procuravam anular os movimentos daqueles que solaparam a instituição da escravidão sem apoiar, contudo, nenhum projeto político autoritário e totalizante. ${ }^{454}$

Por outro lado, havia indícios sugestivos de que a monarquia gozava de popularidade junto aos negros da cidade, o que explicaria, de certa forma, tanto alguns atos de manifesta hostilidade da administração republicana contra os setores mais pobres da população- perseguição a capoeiras e bicheiros, destruição de cortiços etc., logo nos primeiros anos da República- quanto a reação popular contra ações aparentemente benéficas do governo republicano- como a luta contra a vacina obrigatória em 1904.

Em artigo intitulado "Libertos e republicanos", publicado no Diário de Notícias em 19 de março de 1889, Rui Barbosa denuncia com veemência as supostas tentativas da monarquia de garantir a segurança do trono através da mobilização política dos libertos da cidade do Rio. Rui menciona um episódio que teria ocorrido dias antes: uma numerosa

\footnotetext{
${ }^{452}$ FAUSTO, Boris, op. cit. p. 46-47.

${ }^{453}$ ZAFFARONI, E. Raúl; BATISTA, Nilo; ALAGIA, Alejandro; SLOKAR, Alejandro, op. cit. p. 442, 458.

${ }^{454}$ CHALHOUB, Sidney, op. cit. p. 172, 184, 187.
} 
malta de navalhistas, engrossada ainda por trabalhadores pagos pelo governo e armados de "estadulhos" policiais, percorrera a rua do Ouvidor aos gritos de "morte aos republicanos". 455

O imperador talvez tenha sido bem sucedido em seus esforços de vender a imagem de defensor da causa da liberdade dos negros e, portanto, o medo branco da cidade negra parece ter aumentado com o fim da escravidão e da monarquia. As pessoas raramente têm a coragem de admitir simplesmente que têm medo, recorrendo a argumentos lógicos sofisticados para desqualificar e combater aquilo que é visceralmente temido. Sendo assim, os republicanos construíram todo um belo discurso para justificar as suas ações contra a cidade negra. Agiram em nome da higiene, da moral e dos bons costumes, do progresso e da civilização. ${ }^{456}$

\subsection{O componente racial na criminalização do funk}

O atual Código Penal revogou a criminalização da capoeiragem, do espiritismo e da magia, conservou os delitos de curandeirismo e charlatanismo. Mendicância e vadiagem passaram a ser contravenções penais. Apesar das mudanças legislativas, as práticas dos órgãos de segurança pública permanecem discriminatórias. ${ }^{457}$ Um grupo de negros, principalmente homens e jovens, é visto como perigoso e suspeito pela polícia, sendo forte candidato a revistas e blitz. As mesmas instituições que mantêm a ordem social tentam controlar a festa e a massa, mas todas as precauções não conseguem impedir que o aglomerado de pessoas, atingindo certa densidade, origine massas descontroladas, espontâneas, imprevisíveis, eufóricas e violentas. ${ }^{458}$

O perigo das aglomerações aumenta com a emergência da "multidão pós-fordista", fruto do desemprego estrutural, que se configura como "totalidade produtiva indistinta, como conjunto de potencialidades cooperativas que escapam a qualquer regulamentação".

\footnotetext{
${ }^{455}$ CHALHOUB, Sidney, op. cit. p. 169-170. As maltas de capoeira no Rio de Janeiro do século XIX se dividiam em duas facções predominantes: os Nagoas e os Guaiamuns. Além de estarem envolvidos em constantes "desordens", esses grupos serviam a políticos como cabos eleitorais, seguranças de comícios e controladores de "curral eleitoral". Foram os alvos da primeira grande campanha policial da República e desapareceram do imaginário da cidade sendo substituídos pela figura do malandro e do vagabundo (Apud VIEIRA, Thiago Braga. Proibidão de boca em boca: gritos silenciosos de uma memória subterrânea: O funk proibido como fonte para o estudo da violência armada organizada no Rio de Janeiro (1994-2002). 2009. Monografia-Centro de Filosofia e Ciências Humanas, Universidade Federal do Rio de Janeiro, Rio de Janeiro, 2009. p. 30).

${ }^{456}$ CHALHOUB, Sidney, op. cit. p. 185-186.

${ }^{457}$ SILVA JR., Hédio, op. cit. p. 333.

${ }^{45}$ VIANNA, Hermano, op. cit. p. 60.
} 
Diante da incapacidade de governar, regular e disciplinar os comportamentos da multidão, os dispositivos de controle urbano se limitam à vigilância e contenção da massa em guetos para impedir a construção de laços e formas de cooperação social e política que possam dar corpo à rebelião. ${ }^{459}$

O funk carioca tem raízes no funk norte-americano de James Brown, um ícone negro condenado na adolescência por assalto à mão armada que cantava hinos à sexualidade aflorada e à busca por direitos iguais para os negros. ${ }^{460}$ A gíria funky, que remetia ao odor do ato sexual, deixou de ter um significado pejorativo para se tornar um símbolo do orgulho negro, de música "revolucionária", de alegria. ${ }^{461}$ A equipe de som Soul Grand Prix, uma das pioneiras no mundo funk carioca, em um esforço didático e militante de introdução à cultura black is beautiful, entremeava em seus bailes slides de personalidades negras com cenas dos pilotos de Fórmula 1, a única forma de burlar a questão da censura. ${ }^{462}$

O Brasil vivia os anos de ditadura militar e a multidão de negros afirmando o orgulho negro não era bem vista, especialmente em um momento em que todos os conflitos sociais e raciais eram abafados por um espírito cívico e patriota. A resignificação de figuras arquetípicas de redenção racial pela população afro-brasileira e o questionamento do racismo geraram apreensões entre os setores dominantes, foram percebidos como ameaçadores à segurança nacional, subversivos. A polícia política acreditava que por trás das equipes de som existiam grupos clandestinos e radicais de esquerda. DJs e organizadores de baile contam que foram encapuzados e levados para o Departamento de Ordem Política e Social (DOPS) para interrogatórios, que pessoas estranhas ao movimento se infiltraram nos bailes, e que equipamentos de som foram destruídos pela polícia.

As entidades do movimento negro apoiavam os dançarinos para que os bailes e a música fossem um meio para a superação do racismo, mas no discurso das equipes, os bailes não tinham um fim em si, a não ser a pura diversão e as equipes não tinham nada a ver com qualquer espécie de movimento negro. Era a aglomeração de muitas pessoas

\footnotetext{
${ }^{459}$ DE GIORGI, Alessandro. A miséria governada através do sistema penal. Rio de Janeiro: Revan, 2006. p. $79,104,114$

${ }^{460}$ ESSINGER, Silvio, op. cit. p. 9 et seq.

${ }^{461}$ VIANNA, Hermano, op. cit. p. 20; HERSCHMANN, Micael, op. cit. p. 19. Nos EUA, o blues era tocado somente em algumas estações de rádio e em horários específicos para os afro-norte-americanos. Era música proibida para a juventude branca, cujos elementos mais progressistas a escutavam às escondidas dos pais (ARCE, José Manuel Valenzuela. Vida de barro duro: cultura popular juvenil e grafite. Rio de Janeiro: Editora UFRJ, 1999. p. 85). Muitos bluesmen foram acusados de pacto com o demônio (VIANNA, Hermano, op. cit. p. 19).

${ }^{462}$ ESSINGER, Silvio, op. cit. p. 23; HERSCHMANN, Micael, op. cit. p. 21.
} 
negras juntas que assustava e conferiu um tom político aos bailes. Foi o Jornal do Brasil que inventou o nome "Black Rio" e acabou chamando a atenção para o "movimento". Segue abaixo o testemunho de Ivanir dos Santos, Secretário Executivo do CEAP (Centro de Articulação de Populações Marginalizadas) na época:

\begin{abstract}
A ditadura (...) criou uma demagogia que se voltou contra ela: ao mesmo tempo em que incentivou o consumismo, abriu espaços para a venda de música negra produzida naquela época no Brasil, de James Brown, entre outros, e, por outro lado, mobilizou a identidade da população negra. (...). Assim surgiram os grandes bailes black. Isso levou o pessoal a se vestir como se vestiam os negros norte-americanos. A partir disso, a atenção voltou-se para o que acontecia nos Estados Unidos e, junto a isso, para a luta de libertação da África que estava se desenrolando nesse período. Então, se eles o incentivaram como forma de consumo, eles mesmos tiveram de infiltrar o pessoal do SNI (Serviço Nacional de Informação) para destruí-lo, quando perceberam que aquilo era uma forma de aquisição de consciência (...) Quando se percebeu o potencial explosivo que poderia ter (o Black Rio), foi desarticulado. Todo mundo sabe que o SNI pressionou para que não se fizessem os bailes. O pessoal acabou em movimentos mais organizados, mais "comportados", e, por fim, acabou desintegrando-se (...). Mas o Black Rio não tinha projeto, era uma questão muito mais de diversão e identidade do que um projeto político. ${ }^{463}$
\end{abstract}

As tentativas de se desenvolver, naquele momento, qualquer movimento étnico foram enterradas com a repressão implementada pelo regime militar e o boom da moda da discoteca, uma música apreciada tanto na Zona Sul quanto na Zona Norte da Cidade, de espírito mais hedonista, comercial e despolitizada, mais europeizada, domesticada e adaptada ao gosto branco. Os militantes esqueceram os bailes, pois não mais o consideravam um espaço propício para a conscientização. ${ }^{464}$

Hoje, se por uma lado, a etnicidade não é tão tematizada ou celebrada nos bailes, por outro, as representações criminalizantes construídas sobre os frequentadores de baile, principalmente na mídia, estão calcadas numa sutil, mas poderosa "racialização" do discurso que se produz sobre a desordem, a barbárie e a violência. ${ }^{465}$ Se "no funk tem gente de toda cor" e o baile propicia uma mistura de "raças", como procuraram realçar quase

\footnotetext{
${ }^{463}$ ARCE, José Manuel Valenzuela, op. cit. p. 87 et seq.; RIBEIRO, Manoel, op. cit. p. 287; ESSINGER, Silvio, op. cit. p. 35-36; VIANNA, Hermano, op. cit. p. $27-29$.

${ }^{464}$ HERSCHMANN, Micael, op. cit. p. 22; ESSINGER, Silvio, op. cit. p. 42-44; VIANNA, Hermano, op. cit. p. 32.

${ }^{465}$ CUNHA, Olívia M. G. Conversando com Ice-T: violência e criminalização do funk. In: HERSCHMANN, Micael (Org.). Abalando os anos 90: funk e hip-hop - globalização, violência e estilo cultural. Rio de Janeiro: Rocco, 1997. p. 93.
} 
todos os organizadores de bailes, DJs e "funkeiros", quando o funkeiro é vítima de algum tipo de perseguição, as vítimas são "quase tudo da cor". 466

Ainda que enfatizando a "democracia racial" do funk, tanto organizadores como frequentadores do baile salientam que existe uma associação entre a cor negra e o funk, entre dança e o ser negro. O baile não é um reduto de construção de identidade negra diacrítica, mas é um lugar onde o negro pode se sentir à vontade, onde o corpo e o visual negro não são criminalizados, mas sim muitas vezes premiados. A forma pela qual se dá a desinibição do negro está expressa nas experimentações com o visual, no uso do corpo e não nas formas sugeridas pela militância negra. ${ }^{467}$ Os funkeiros não afirmam expressamente sua identidade negra, mas a "sugerem, através de sua própria presença, da visibilidade que adquirem, colocando em cena seus corpos coreograficamente arranjados". Há uma provocação não-verbal do conflito, que leva à armadilha do estereótipo que associa o corpo negro à sexualidade e os negros à irracionalidade. ${ }^{468}$

\subsection{Seletividade e distância social}

Quando os meios de comunicação de massa fizeram a cobertura dos arrastões de 1992/1993, o que esteve explicitamente em jogo não foi propriamente a cor dos jovens envolvidos, mas o fato de serem "desordeiros" e/ou "delinquentes". Há, no entanto, um "subtexto" que se apoia em imagens que foram veiculadas e que associam a presença de grupos de "jovens de cor" à turba e a um clima de pânico. Os participantes do arrastão foram taxados, em contraposição aos caras-pintadas que pediam o impeachment do presidente Collor, de "caras-pintadas da periferia", os caras pintadas "naturais", que não precisam de tinta, e a pele escura dos infratores foi enfatizada em muitas reportagens. Se, por um lado, frequentemente os noticiários associaram o funk com organizações criminosas, por outro lado, também caracterizavam, de forma indireta ou implícita, essas

\footnotetext{
${ }^{466}$ CUNHA, Olívia M. G. Bonde do mal. In: MAGGIE, Yvonne; REZENDE, Cláudia B. (Org). Raça como retórica: a construção da diferença. Rio de Janeiro: Civilização Brasileira, 2001. p. 138; SILVA, Suylan Midlej e. O lúdico e o étnico no funk do "Black Bahia". In: SANSONE, Livio; SANTOS, Jocélio Teles dos (Org.). Ritmo em trânsito: sócio-antropologia da música baiana. Salvador: Dynamis Editorial, 1997. p. 214. ${ }^{467}$ SANSONE, Livio, op. cit. p. 179-180; SILVA, Suylan Midlej e, op. cit. p. 203, 211.

${ }^{468}$ CECCHETTO, Fátima; FARIAS, Patrícia, op. cit. p. 55-56.
} 
manifestações culturais como sendo práticas dos segmentos negros ou, pelo menos, "pobres" da cidade. ${ }^{469}$

Em um contexto em que parte da mídia alardeava um discutível aumento da criminalidade no Rio de Janeiro, as imagens de jovens- em grande maioria não-brancoschegando aos milhares nas praias se misturavam às imagens do recrutamento maciço de jovens nas favelas pelas quadrilhas do tráfico e geravam o temor da desordem urbana presumivelmente associada a um confronto racial, como a dos distúrbios de Los Angeles do mesmo ano. "Cor, pobreza, juventude e funk pareciam subtemas de um só enredo tendendo a explicar a violência pelo enfoque da exclusão e o racismo pela percepção de que há 'diferenças`culturais que perpassam e explicam tais atitudes".

Até para escapar das acusações de racismo, os jornalistas assinalaram que as prováveis “diferenças" entre a massa juvenil descontrolada e os moradores da Zona Sul da cidade não estariam relacionadas somente ao poder aquisitivo nem à cor dos frequentadores, mas, sobretudo, a diferenças culturais. Termos como "cultura da periferia", "cultura suburbana" e "cultura da favela", muitos deles incorporados pelos próprios marginalizados como sinal de orgulho e resistência, "resvalam uma inocente intenção de marcar e naturalizar desigualdades sociais e raciais". ${ }^{470}$

469 HERSCHMANN, Micael, op. cit. p. 65-67; YÚDICE, George. A funkificação do Rio. In: HERSCHMANN, Michael (Org.). Abalando os anos 90: funk e hip-hop - globalização, violência e estilo cultural. Rio de Janeiro: Rocco, 1997. p. 34.

${ }^{470}$ Em uma foto da cobertura do arrastão pelo Jornal do Brasil três rapazes se olhavam de lado. Os dois negros tinham tarjas sobre os olhos. O garoto branco, não. Não ocorreu ao repórter que os três fossem igualmente responsáveis pelo que quer que ali se passasse (CUNHA, Olívia M. G. Conversando com Ice-T: violência e criminalização do funk. In: HERSCHMANN, Micael (Org.). Abalando os anos 90: funk e hiphop - globalização, violência e estilo cultural. Rio de Janeiro: Rocco, 1997. p. 90-91). Uma revista colocou a fala de uma dona de casa de que "era um bando mal-encarado de gente escura, pobre e mal vestida" entre aspas para não assumir o preconceito explícito no depoimento e se eximir da responsabilidade de ter que responder por essa declaração (MENDONÇA, Kleber. A onda do arrastão. In: Discursos Sediciosos: crime, direito e sociedade, ano 4, $\mathrm{n}^{\circ}$ 7-8. Rio de Janeiro: Freitas Bastos/Instituto Carioca de Criminologia, $1^{\circ}$ e $2^{\circ}$ semestres de 1999. p. 272). Ser racista no Brasil é talvez, ainda hoje, considerado um pecado capital na medida em que coloca em xeque o mito de origem da sociedade brasileira, o "mito das três raças", o qual representa a diferença suprimindo-a, colocando-a num passado, e atenta contra a ideia de uma unidade cultural nacional (HERSCHMANN, Micael, op. cit. p. 73-74). "O racismo se constrói num quadro de desigualdade de poderes sociais que reproduz a subordinação de um grupo social por outro, mas sua expressão, para além de disposições jurídicas e normativas, manifesta-se através de múltiplos canais que vão desde as proibições explícitas até a dimensão tênue, mas humilhante, do olhar e do discurso gestual. Aqui a construção dos outros é ameaçadora, sua conduta é violenta, seus atos criminosos. O 'monstro' vai adquirindo vida própria e chega a aterrorizar de verdade, ameaçando a habitabilidade da cidade. Eventualmente, os portadores das identidades proscritas aprendem a usar a imagem que lhes é atribuída. Seus delitos e crimes reais servem para manter as aparências de credibilidade do estereótipo; são evidências que justificam os preconceitos dos setores médios e altos sobre os pobres favelados, funkeiros, rapeiros, cholos e chavos, banda das zonas populares ou sobre a convicção extravagante dos punks" (ARCE, José Manuel Valenzuela, op. cit. p. 79-80). 
O que parece ser frequentemente destacado como causa da desordem é a origem e o comportamento desses suburbanos desordeiros, que "gritam e têm hábitos alimentares bizarros". Atribui-se essa "diferença cultural" ao desregramento, à falta de ética, à certeza da impunidade diante daqueles que deveriam vigia-los e reprimi-los. ${ }^{471}$ São produzidas novas categorias, tais como "bairros sensíveis", contendo "populações com problemas", atormentadas por todos os tipos de "violências urbanas", bem como discursos paternalistas, como o que defende que a maior repressão das "incivilidades" nos "bairros sensíveis" favorece em primeiro lugar seus próprios habitantes. ${ }^{472}$

O conceito de desordem utilizado pela teoria das janelas quebradas, contudo, é problemático, uma vez que pode ter distintos significados dependendo do contexto e das comunidades em que os atos de incivilidade ocorreram. Certas atitudes, como grafitar, urinar em público, jogar papel nas ruas e pular roletas de ônibus foram identificadas como condutas desordeiras e de alguma forma vinculadas ao crime em larga medida, em detrimento de outras, como evasão fiscal, corrupção, fraude e brutalidade policial. Jogar papel na rua não é percebido como uma violação a uma regra de conduta em todas as comunidades. Assim como o crime é uma construção e não uma entidade ontológica, o conceito de "desordem" não é natural.

É mais fácil atribuir a criminalidade, as desordens, as incivilidades e a decadência de "bairros sensíveis" à degeneração moral dos indivíduos, à decadência dos valores tradicionais da família, à "falta de vergonha na cara", à "vagabundagem" e à ausência do Estado Policial do que ao desemprego, à crise econômica, à ausência do Estado Social ou quaisquer outras razões sociais ou coletivas. Esse diagnóstico nos protege do sentimento de impotência em face de "desafios realmente formidáveis". ${ }^{473}$ De acordo com Olívia M. G. Cunha,

\footnotetext{
Estudos que trabalham com a noção de "pânico moral" entre grupos juvenis têm analisado a multiplicidade de visões e interesses que podem estar em jogo no processo de estigmatização. No cenário carioca, a hesitação quanto a uma caracterização mais estreita dessa parcela da população em termos raciais redundou num discurso fortemente anti-racista e o tema das desigualdades sociais acabou enredado numa complexa teia de análises que conclamavam pela
}

\footnotetext{
${ }^{471}$ CUNHA, Olívia M. G. Bonde do mal. In: MAGGIE, Yvonne; REZENDE, Cláudia B. (Org). Raça como retórica: a construção da diferença. Rio de Janeiro: Civilização Brasileira, 2001. p. 92, 95.

${ }^{472}$ WACQUANT, Loïc. Punir os pobres: a nova gestão da miséria nos Estados Unidos. Rio de Janeiro: Freitas Bastos, 2001. p. 141.

${ }^{473}$ BELLI, Benoni. Tolerância Zero e democracia no Brasil: visões da segurança pública na década de 90. São Paulo: Perspectiva, 2004. p. 66 et seq.; WACQUANT, Loïc. A globalização da "Tolerância Zero". In: Discursos Sediciosos: crime, direito e sociedade, v. 9/10. Rio de Janeiro: Freitas Bastos, 2000. p. 114.
} 
distribuição do "bolo" e por mais polícia. Mas em algo, talvez, os vários interlocutores que se posicionaram nas páginas dos jornais cariocas acabaram concordando: a pobreza e o ambiente de marginalização, ausência de Estado, educação, desemprego e violência propiciavam uma forma particularprincipalmente por parte dos jovens- de consumir, de se relacionar com a cidade e de expressar suas angústias. Foi justamente nesse momento que o funk apareceu como exemplo de expressão juvenil e elogio à violência. Ou seja, observou-se um processo de "criminalização do funk", no qual, à guisa de estigmatizar seus consumidores preferenciais, "demonizou-se" o próprio estilo, como fonte e estímulo da violência. ${ }^{474}$

A identidade de "funkeiro", praticamente inexiste entre os frequentadores de baile, e o funk acabam sendo preferido menos por suas características próprias e mais por ser a única opção de lazer desses adolescentes. Contudo, a imprensa cria justamente uma identidade de grupo ao utilizar o termo "funkeiro" para se referir aos participantes do arrastão, associando a uma atitude que aponta como criminosa não um bando de "pivetes", mas todo um segmento social (negro, pobre e suburbano) cujas práticas culturais quase sempre são tratadas com um "sotaque de racismo" e um alto grau de estranheza pelos jornalistas. A imprensa tem dificuldade até de considerar o baile como uma manifestação cultural possível. ${ }^{475}$

A violência nos bailes funk sempre existiu, assim como em qualquer lugar onde haja aglomerações de jovens. Porém, com o passar do tempo, aumentou a relevância que as brigas passaram a ter nos bailes e mudou a percepção sobre elas. O conflito é parte constitutiva da vida social, em todas as sociedades, mas nem sempre ele é visto como violento. Em sociedades complexas, fenômenos que são considerados violentos para determinados grupos, como as danças executadas em shows punks, as lutas de boxe, a dança/luta da capoeira e as negociações no pregão das bolsas de valores, não são para outros.

Há alguns casos em que a violência é percebida como tal, mais ou menos consensualmente, por vários grupos sociais, mas essa visão não contamina a totalidade do espaço social onde o acontecimento considerado violento foi gerado. Ninguém fala, por exemplo, que as boates frequentadas pela alta classe média carioca são territórios violentos

\footnotetext{
${ }^{474}$ CUNHA, Olívia M. G. Conversando com Ice-T: violência e criminalização do funk. In: HERSCHMANN, Micael (Org.). Abalando os anos 90: funk e hip-hop - globalização, violência e estilo cultural. Rio de Janeiro: Rocco, 1997. p. 91-92.

475 MENDONÇA, Kleber, op. cit. p. 271. O gosto musical dos frequentadores do baile funk é bastante eclético. O funk dominou os bailes por ser o preferido para dançar. A relação da maior parte do público com a música que está sendo tocada é efêmera, "funcional", completamente descartável (VIANNA, Hermano. $O$ mundo funk carioca. 2 ed. Rio de Janeiro: Zahar, 1988. p. 91-92).
} 
ou produtores de violência quando ocorrem brigas. ${ }^{476} \mathrm{O}$ fato de não haver uma familiaridade com o funk facilita sua demonização. O grau de "exotismo" de um fenômeno social é uma função quase direta da possibilidade de vê-lo transformado em estereótipo por grupos para os quais esse fenômeno é considerado exótico. A realidade das boates da Zona Sul é mais familiar para jornalistas. ${ }^{477}$

A violência constantemente associada aos grupos juvenis dos centros urbanos é, na verdade, uma interpretação jornalística. A questão, sob a perspectiva da teoria crítica, não é negar que alguns "funkeiros" são violentos, mas "repensar de que forma suas falas e atitudes se diferenciam daquelas produzidas por outros jovens mais integrados na estrutura social", ou seja, questionar por que são os setores mais vulneráveis à repressão que se tornam sinônimo da "delinquência juvenil" e "pagam o pato" pela violência que existe em todos os estratos sociais. ${ }^{478}$

Enquanto para os delitos produzidos pelos jovens de classe média, o tom da mídia é sempre de "surpresa" e busca-se atribuir "causas" que expliquem tais condutas “desviantes", os delitos praticados por jovens pobres são quase sempre interpretados como atos que confirmam uma regra, um padrão de conduta. ${ }^{479}$ A violência produzida por jovens de classe média é lida como uma situação de exceção, como casos isolados, muitas vezes motivados por problemas psíquicos, enquanto a promovida por jovens dos segmentos populares é considerada um problema social, indícios de uma conduta padrão, coletiva. ${ }^{480}$

476 VIANNA, Hermano. O funk como símbolo da violência carioca. In: VELHO, Gilberto; ALVITO, Marcos. Cidadania e violência. Rio de Janeiro: UFRJ/FGV, 1996. p. 178-179. Parece haver certa identificação entre os grupos em que o conflito se coloca de forma central, como, por exemplo, funkeiros e metaleiros. "Metaleiros e funkeiros gostam de conversar muito, porque os dois gostam de briga" (GUIMARÃES, Eloísa. Escola, Galeras e Narcotráfico. Rio de Janeiro: Editora UFRJ, 2003. p. 153-154). "A noção de violência construída por um jovem é em parte retirada do que realmente acontece; da sua consciência de classe; da sua posição na sociedade; das suas interações sociais na escola, na família e com as mensagens da mídia; da sua experiência com esse fenômeno; do imaginário coletivo; e de como sua subjetividade processa e reage a esse conjunto de relações e estímulos. A consciência dos jovens sobre o fenômeno teria, portanto, o peso das ideias hegemônicas que criam as estruturas imaginárias de relevância, do desenvolvimento de suas experiências enquanto grupo etário, estrato social, gênero e etnia, e também dos fatos concretos que acontecem com eles ou que presenciam" (MINAYO, Maria Cecília de Souza et alii, op. cit. p. 148-150).

477 VIANNA, Hermano. O funk como símbolo da violência carioca. In: VELHO, Gilberto; ALVITO, Marcos. Cidadania e violência. Rio de Janeiro: UFRJ/FGV, 1996. p. 184. Repórteres quase nunca mencionam a dimensão simbólica da violência no funk, importante na construção de uma sociabilidade juvenil, no caso, a galera. As brigas sempre existiram em maior ou menor intensidade. Foram a mídia e o Estado que identificaram nestes confrontos um fator impeditivo à realização plena dos bailes. E foi sob a ameaça da interdição total que vários MCs e empresários incorporaram um discurso que solicitava a “pacificação dos bailes”. (HERSCHMANN, Micael, op. cit. p. 175-176).

${ }^{478}$ HERSCHMANN, Micael, op. cit. p. 88-89; ARCE, José Manuel Valenzuela, op. cit. p. 97-98.

${ }^{479}$ HERSCHMANN, Micael, op. cit. p. 79.

480 Ibid p. 280; MACEDO, Suzana. DJ Marlboro na terra do funk- Bailes, bondes, galeras e MCs. Rio de Janeiro: Dantes Livraria e Editora, 2003. p.108. "Jovens das 'classes populares` figuram em grande parte nos 
O DJ Marlboro reclama que as autoridades não tomaram contra os "funkeiros" a mesma atitude que tomaram contra os pitboys de classe média e alta. Enquanto na Zona Sul identificaram os pitboys que quebravam boates e colocaram policiamento nos locais garantindo a diversão de quem queria se divertir, simplesmente fecharam os bailes funk, talvez por que "é mais cômodo", é "diversão dos pobres". ${ }^{481}$ Ao invés de a legislação estadual administrativa coibir, em abstrato, as brigas e o volume alto do som, independentemente do local onde ocorram, elege como alvo especificamente o "baile funk".

Os criminólogos radicais denunciam a existência de uma justiça de classe, na qual se refletem as linhas de fratura e conflito que, a nível macroscópico, dominam cada formação social. ${ }^{482}$ Os juízes, na sua maioria recrutados nas classes dominantes ou, pelo menos, sem consciência de classe se oriundos de outras classes sociais, têm uma tendência de não se identificar existencialmente com a figura do réu. Quando o réu é de uma classe desfavorecida, a tendência de condená-lo é ainda maior, em razão dos preconceitos, estereótipos e demonizações decorrentes da distância social, do insuficiente conhecimento e capacidade de penetração no mundo do acusado.

Há diferenças de atitude emotiva e valorativa dos juízes em face de indivíduos pertencentes a diversas classes sociais. Observa-se a tendência por parte dos magistrados de esperar um comportamento conforme a lei dos indivíduos pertencentes aos estratos médios e superiores, procurar a verdadeira criminalidade principalmente naqueles estratos sociais dos quais é normal esperá-la e julgar que a pena detentiva, a sanção que mais incide sobre o status social, é menos comprometedora para o status social já baixo. Observa-se uma maior atuação das instâncias formais de controle social, estigmatizantes, seletivas, discriminatórias e criminógenas, sobre as camadas mais débeis da população, enquanto as

estudos sobre favelas/comunidades populares, criminalidade e violência; enquanto a 'cultura juvenil tende a ser encerrada nos limites dos estudos sobre camadas médias, classes médias urbanas e o impacto da globalização das cidades latino-americanas. Enquanto os aspectos socioeconômicos e a crescente criminalização de adolescentes pobres explicam as escolhas e os comportamentos, nas camadas médias uma 'cultura individualista' e essencialmente urbana possibilita outras escolhas e comportamentos (CUNHA, Olívia M. G. Conversando com Ice-T: violência e criminalização do funk. In: HERSCHMANN, Micael (Org.). Abalando os anos 90: funk e hip-hop - globalização, violência e estilo cultural. Rio de Janeiro: Rocco, 1997. p. 108).

481 Apud MEDEIROS, Janaína, op. cit. p. 57-58. Atentou-se para o perigo de o "tráfico" usar mensagens em "proibidões" para aliciar menores, mas não se encontram mães, juízes de menores e policiais, pelo menos no Brasil, preocupados com os possíveis rituais satânicos dos quais os fãs de trash e heavy metal poderiam estar participando (CUNHA, Olívia M. G. Cinco vezes favela- um reflexão. In: ALVITO, Marcos; VELHO, Gilberto (Org.). Cidadania e Violência. Rio de Janeiro: UFRJ e FGV, 1996. p. 207).

${ }^{482}$ DIAS, Jorge Figueiredo; ANDRADE, Manuel da Costa. Criminologia: o homem delinquente e a sociedade criminónega. Coimbra: Editora Coimbra, 1992. p. 385-386. 
camadas dominantes conseguem, através da reação informal, preservar seus indivíduos de caírem sob os mecanismos e as sanções do sistema institucional. ${ }^{483}$

\subsection{Os caras-pintadas da periferia: a criminalização da juventude}

O fato de o arrastão do Arpoador ter ocorrido logo após as passeatas dos caraspintadas pedindo o impeachment do presidente Fernando Collor pela via jurídico-política foi realçado pelos jornais, mais uma vez como forma de criminalizar a juventude negra das favelas e periferias. Enquanto os caras-pintadas foram tratados como motivo de orgulho, uma reedição do modelo de jovem idealista dos anos 60, os participantes do arrastão, “caras-pintadas da periferia", foram taxados de juventude desesperançada, despolitizada, hedonista, transviada, rebelde sem causa, motivo de vergonha. A imagem negativa da juventude se tornou ainda maior nos últimos anos diante da ausência de fenômenos sociais similares ao do movimento dos caras-pintadas e a presença cada vez mais constante nos jornais de discursos que narram acontecimentos violentos envolvendo jovens.

Não se deve perder de vista, porém, que "juventude" é um conceito historicamente construído e associado a diversas características que não necessariamente se vinculam à idade cronológica. Sendo assim, o jovem é aquele que se encontra entre a fase irresponsável da infância e o mundo responsável dos adultos, no qual o trabalho e a constituição de uma família são determinantes. Características associadas à juventude são bastante valorizadas pela sociedade, como a saúde, o lazer, a diversão, o consumo cultural, a virilidade, a esperança, o idealismo, etc. Paradoxalmente, essa mesma juventude, ou pelo menos parte dela, não encontra inserção socioeconômica real, é vista como uma ameaça criminalizada bastante associada à violência, embora esta seja apenas uma das facetas do jovem, um ser bastante complexo. Além disso, não se pode esquecer que o jovem é a maior vítima da violência e, principalmente, que a violência não é um fenômeno restrito a este grupo social. Ela permeia a sociedade como um todo, inclusive seus meios de comunicação.

Deve-se levar em conta que o recente boom das expressões juvenis populares, como o funk, vem ocorrendo em um clima de "crise" generalizada, de sensação de incremento

\footnotetext{
${ }^{483}$ BARATTA, Alessandro, op. cit. p. 177 et seq. A posição precária no mercado de trabalho, defeitos de socialização familiar e escolar não são considerados pelos críticos causas da criminalidade, mas estereótipos que guiam a atribuição do status de criminoso (GOMES, Luiz Flávio; GARCÍA-PABLOS DE MOLINA, Antonio. Criminologia. 3. ed. São Paulo: RT, 2000. p. 569).
} 
mundial da violência, o que, aliado a outros fatores, como o racismo, têm acentuado a representação negativa do jovem de classe baixa. A sociedade despeja todas as suas expectativas sobre a juventude, mas não oferece a ela os meios necessários para atingir as metas culturais. A crise econômica e o desemprego avassalador dos anos 90 jogaram à margem do mercado de trabalho milhares de jovens que, confrontados com a falta de perspectivas profissionais, ainda foram responsabilizados pela situação sob o rótulo de "desesperançados".

No auge do neoliberalismo, a mesma juventude assediada por anúncios publicitários foi acusada de ser individualista, hedonista, consumista e despolitizada, sendo cobrada de acordo com o modelo do jovem idealista e politizado dos anos 60, que lutou contra a ditadura militar. Essa forma de representar a juventude permaneceu como referência de análise, o que significou, para muitas reflexões posteriores, a desqualificação das manifestações juvenis dos anos subsequentes. Não se questiona, porém, a crise de todos os projetos utópicos coletivos no mundo após a queda do muro de Berlim, o fato de o capitalismo ter ficado muito mais competitivo e selvagem, bem como a crise de legitimidade dos partidos políticos e da política institucional como via de transformação social.

Mais do que despolitizada, talvez a juventude dos anos 90 tenha simplesmente encontrado outra forma de fazer política, diferente da juventude dos anos 60, abdicando dos canais políticos tradicionais. A juventude dos anos 90 busca o lazer e a cultura em contraposição a um cotidiano medíocre e insatisfatório. Eles parecem assumir o fato de que não são capazes de produzir grandes projetos de transformação, e que sua ação genuína só pode ser a de se oferecer como espelhos de seu tempo, construindo "espetáculos" que chamem a atenção pública e denunciem a falência dos projetos existentes. ${ }^{484}$

A esperança em um futuro melhor, trazida pelo movimento dos "caras-pintadas", foi destruída com a constatação da existência de uma outra juventude, até então esquecida e muito mais selvagem, para quem o movimento dos "caras-pintadas" não fazia muito sentido, já que ela vivia uma outra realidade, não acreditava nos canais tradicionais/institucionais de representação política e estava preocupada em trazer uma outra mensagem, a das favelas e subúrbios. "Os funkeiros rejeitam o espetáculo de

${ }^{484}$ HERSCHMANN, Micael, op. cit. p. 51 et seq.; NETO, Ana Maria Q. Fausto; QUIROGA, Consuelo. Juventude urbana pobre: manifestações públicas e leituras sociais. In: PEREIRA, Carlos Alberto Messeder; RONDELLI, Elizabeth; SCHOLLHAMMER, Karl Erik; HERSCHMANN, Micael. Linguagens da violência. Rio de Janeiro: Rocco, 2000. p. 221-222; ARCE, José Manuel Valenzuela, op. cit. p. 73-75, 82 et seq. 
democracia do qual participaram os caras-pintadas e não têm motivos para comemoração". ${ }^{485}$ Também não têm nada a perder. Quando questionado por que o seu grupo não tinha participado das passeatas pela queda do presidente Collor, um desses rapazes pobres respondeu que isso "era coisa de mauricinhos". 486

De acordo com Arce, as representações dominantes são seletivas e se constroem num quadro de disputa. Na década de 30, as perspectivas dominantes estabeleceram que nas zonas e bairros populares haviam delinquentes, desocupados ou trabalhadores, mas não movimentos juvenis. Durante as décadas de 70 e 80 , o jovem das favelas conseguiu finalmente maiores êxitos de expressão, construiu novas formas de recreação e de resistência cultural, apesar de a resposta social dominante tê-lo reduzido à imagem ameaçadora de delinquência e crime. ${ }^{487}$

Neste ponto, a emergência de movimentos culturais como o funk e o hip hop são importantíssimos, uma vez que colocam o jovem da periferia pela primeira vez no protagonismo da condição de ser jovem e reivindicar seus direitos na esfera da cultura, seja por meio das letras de raps e funks, seja por meio de invasões simbólicas e ruidosas na cidade, rotuladas como badernas anárquicas pré-políticas ${ }^{488}$. A interpretação da fala emotiva e espontânea desses jovens nas músicas constitui uma fonte importante de informação, pois as letras expressam sua experiência geracional, suas perspectivas e sua análise da sociedade. ${ }^{489}$

Sinalizam uma não aceitação dos estigmas e violências a que estão submetidos. Seus locais de moradia e sua origem social não são mais ocultados com vergonha, mas

\footnotetext{
485 YÚDICE, George, op. cit. p. 38; HERSCHMANN, Micael, op. cit. p. 213.

${ }^{486}$ Apud CARMO, Paulo Sérgio do, op. cit. p. 167-169.

487 Sobre a criminalização do pachuquismo, subcultura das décadas de 30, 40 e 50, composta por jovens pobres do norte do México e chicanos dos EUA, cf. ARCE, José Manuel Valenzuela, op. cit. p. 75 et seq.

${ }^{488}$ Segundo Roberto Da Matta, "quando são os pequenos (ou estruturalmente fracos) que clamam por seus direitos, esse clamor assumirá sempre a forma de uma violência pessoalizada e 'pré-política` isto é, um estilo de violência que se manifesta por grupos de interesses difusos através de grupos ad hoc e sem nenhuma planificação. Realmente, seu estilo espontâneo é que legitima, como um bom desfile carnavalesco, o protesto destrutivo que promovem" (Apud HERSCHMANN, Micael, op. cit. p. 47). Vieira aponta o preconceito social e político em atribuir às revoltas do lumpem proletariat os atributos da "irracionalidade" e "desordem". Para o pensamento direitista, essas ações coletivas são associadas à "barbárie" e ao "terror". Já o pensamento esquerdista mais ortodoxo, obsecado pelo paradigma revolucionário, dilui a importância da atuação de tais grupos sociais e aponta os valores individualistas de suas lideranças, sua brevidade, pontualidade e espontaneísmo, a ausência de clareza programática e direção revolucionária. Foram consideradas, enfim, uma distração que "desencaminha as energias da luta de classes para dimensões de atuação egoístas, conformistas e muitas vezes conservadoras" (VIEIRA, Thiago Braga, op. cit. p. 13 et seq).

${ }^{489}$ QUEIROZ, Tereza Correia da N. Culturas juvenis, contestação social e cidadania: a voz ativa do hip hop. In: ALVIM, Rosilene; JUNIOR, Edísio Ferreira; QUEIROZ, Tereza (Org.). (Re)construções da juventude: cultura e representações contemporâneas. João Pessoa: Editora Universitária-PPGS/UFPB, 2004. p.15-16, 29-30.
} 
assumidos explicitamente nas letras e "gritos de guerra" como maneira de se autoafirmarem, muitas vezes pela intimidação. Demandam o reconhecimento não só de igualdades, mas de diferenças. Por sua vez, o valor atribuído a bens de consumo manifesta o desejo de integração em uma sociedade na qual "o reconhecimento e a aceitação social dependem cada vez mais do consumo ou 'daquilo que se possua ou seja capaz de possuir"', 490

O funk expressa o "desejo de ir e vir", que é negado quando o favelado e o suburbano não estão na pista de dança. A emoção, que no ato da dança é experimentada como um sentimento de raiva, não é usada para um propósito social e político maior, mas “é a maneira pela qual a juventude pobre constrói seu mundo contra as restrições do espaço e contra a convicção, corretamente deduzida, de que canalizar a raiva para algum objetivo social e político só leva à ingenuidade". ${ }^{491} \mathrm{O}$ funk e o hip hop retraçam novas fronteiras socioculturais e espaciais ao ocupar espaços nobres da cidade anteriormente exclusivos às camadas médias, ao possibilitar o encontro entre diferentes segmentos sociais, ao se articular à cultura institucionalizada e ao mercado.

Com exceção de alguns funks conscientes, os funks, ao contrário dos raps do hip hop, não costumam expressar explicitamente em suas letras a insatisfação e os conflitos sociais, mas estes aparecem na ritualização da violência nos bailes, em brigas, quebraquebras e arrastões, o que reforça o estereótipo de juventude violenta e alienada. ${ }^{492}$ Estes conflitos ocorrem entre as próprias galeras do subúrbio e refletem sua realidade violenta, o que não impediu que alguns analistas enxergassem nos arrastões uma espécie de "revide" das classes mais carentes contra as mais abastadas e que estas se sentissem ameaçadas e chocadas em ver pobres se digladiando no território historicamente pertencente a elas, gerando reações intolerantes em que o clima de segregação social e racial ficou claro. ${ }^{493}$

Curiosamente, apesar de serem acusados de apáticos e alienados, os jovens de classe baixa dos anos 90, principalmente os adeptos do hip hop, se consideram mais politizados do que seus pais, ao contrário dos jovens de classe média e alta. ${ }^{494}$ Talvez seja exatamente essa diferença de posturas geracionais que torne a juventude de classe baixa tão assustadora, ameaçadora, perigosa e incômoda. Os jovens estão saindo do lugar onde sempre estiveram seus pais, que viveram sua subordinação e confinamento a determinados

\footnotetext{
${ }^{490}$ NETO, Ana Maria Q. Fausto; QUIROGA, Consuelo, op. cit. p. 232-233.

${ }^{491}$ YÚDICE, George, op. cit. p. 48-49.

${ }^{492}$ HERSCHMANN, Micael, op. cit. p. 212-214.

${ }^{493}$ MENDONÇA, Kleber, op. cit. p. 271.

${ }^{494}$ CARMO, Paulo Sérgio do, op. cit. pp. 172-173.
} 
espaços da cidade com normalidade. Invadir as praias e transitar coletiva e ruidosamente pela cidade indicam a quebra de um pacto territorial, a ampliação dos limites impostos aos diferentes grupos, na sua convivência urbana e social, uma mudança de posicionamento dos jovens frente à ordem social, sem representar necessariamente delinquência ou manifestações da violência urbana. ${ }^{495}$

Os jovens do hip hop apresentam um discurso bastante racial e crítico, que vai de encontro ao mito brasileiro da democracia racial e do homem pacífico. Uma atitude bem diferente dos trabalhadores honestos, "obedientes" e conformados que tinham com seus patrões um laço de gratidão e amizade em uma sociedade na qual trabalho e capital supostamente viviam em harmonia. A figura do malandro alegre, outrora perseguida pela polícia, pelo menos contemporiza, negocia, com seu "jeitinho” brasileiro e ginga. Mulata, carnaval, feijoada e futebol são os símbolos nacionais máximos da "cordialidade" brasileira, da conciliação de classes e raças, da sociedade plural, mas "não-violenta", harmônica. O hip hop e o funk, ritmos "importados" dos guetos negros norte-americanos, contestam essa imagem e denunciam, ainda que muitas vezes inconscientemente, a realidade de conflito, desemprego, miséria, racismo, violência e narcotráfico e isso é um dos motivos que os faz tão subversivos, a ponto de serem criminalizados. ${ }^{496}$

A onda de desencanto que acompanhou a chegada dos anos 90 no Brasil criou a tendência de idealizar o passado como a "idade de ouro", em que os mundos dos ricos e dos pobres se olhavam sem medo ou ódio, as distâncias sociais eram menores e faziam rir. As favelas de então, mais do que ameaça ou problema, eram vistas de longe como um acidente pitoresco. Como já dizia o sambista Herivelto Martins, "quem mora lá no morro já vive pertinho do céu". ${ }^{497}$ Já no discurso contestador do hip hop, a relação com as classes abastadas é de oposição e luta.

Os símbolos da pretensa democratização da sociedade brasileira são criticados por representarem “formas de escamotear a permanência da discriminação". O carnaval não é mais visto como festa do povo, mas como a festa em que o preto se vendeu e rendeu-se ao branco, passando a ocupar um lugar secundário. A mulata é denunciada como símbolo de exploração da mulher negra. O hip hop "afirma os valores e a força de seus guerreiros, que

\footnotetext{
${ }^{495}$ NETO, Ana Maria Q. Fausto; QUIROGA, Consuelo, op. cit. p. 233-234.

${ }^{496}$ HERSCHMANN, Micael, op. cit. p. 33 et seq.; RIBEIRO, Manoel, op. cit. p. 292.

${ }^{497}$ VENTURA, Zuenir, op. cit. p. 17-18.
} 
têm orgulho da sua cor e da sua origem, e que buscam saídas alternativas ao crime e à submissão aos mais poderosos". 498

Segundo George Yúdice, na transição para a democracia, "ficou evidente a inviabilidade da emancipação política e social por meio das práticas culturais formadoras de um 'consenso', que permite a distribuição da riqueza para as elites e de uma pobreza maior para os segmentos subalternos". A nova realidade das gangues de rua, do narcotráfico e dos meninos de rua "substituiu o velho mito da cordialidade pelo da premonição de uma 'explosão social"'. A livre penetração do samba no espaço é substituída pela tomada do espaço pelos jovens "através da violência e da demonstração de força inerente ao ritmo urbano norte-americano das metralhadoras". 499

Tanto o funk quanto o hip hop são acusados de promoverem festas, músicas e danças que incitam a violência. A diferença é que o funk é considerado perigoso por produzir uma conduta inconsequente, que glorifica a delinquência e as brigas, e o hip hop é considerado perigoso por produzir um discurso radical, conflituoso, hiperpolitizado, simbolicamente violento, que incita a revolta das minorias. ${ }^{500}$ A dimensão de resistência do funkeiros está em sua capacidade de assumir uma identidade proscrita, associada à violência, insegurança, arrastões e decomposição moral, o que os expõe à intolerância social e racial, os estigmatiza e os condena a suspeita constante. Só com sua presença no espaço público, os funkeiros se opõem à segregação, "evidenciam e questionam um universo simbólico dominante que pretende condená-los ao silêncio e à clandestinidade". 501

O arrastão, acusado de causar fissuras sociais e raciais, apenas torna evidente os conflitos sociais e raciais previamente existentes e abafados, causados por políticas públicas excludentes. Ele expõe que a sociedade brasileira não é harmoniosa, mas fragmentária, autoritária e hierarquizada, que existe racismo e uma juventude pobre que, ao

\footnotetext{
${ }^{498}$ QUEIROZ, Tereza Correia da N., op. cit. p. 23 et seq.

${ }^{499}$ YÚDICE, George, op. cit. p. 26-27. A cultura do funkeiros "rejeitou a promessa de civilidade apresentada por intelectuais e políticos tanto da esquerda como da direita e até mesmo do movimento negro. Ela resistiu aos predicados de participação- representação cultural sem acesso aos bens materiais e aos serviços- típicos da relação clientelista aceita pela cultura do carnaval e do samba" (Ibid. p. 43). Na opinião de Herschmann, mesmo que o funk e o hip-hop estejam hoje bastante presentes na indústria cultural e pareçam aproximar diferentes segmentos sociais, não se traduzem, tal como o samba, em práticas culturais confraternizadoras. (HERSCHMANN, Micael, op. cit. p. 215-216). Cabe ressaltar ainda que muitos jovens que ouvem e dançam funk gostam igualmente ou até mais de outros estilos "confraternizadores", como o samba e o axé.

${ }^{500}$ HERSCHMANN, Micael, op. cit. p. 192-193.

501 O mesmo processo histórico de condenação ocorreu com bailes e danças populares como rumbas, guarachas, jaranas, gatos, danzones e habaneras antes da independência mexicana e com expressões de dança afro-brasileiras no Brasil (ARCE, José Manuel Valenzuela, op. cit. p. 101-102).
} 
contrário de seus pais, não pede passagem para desfilar de forma ordeira apenas uma vez por ano e, apesar da rebeldia, reivindica integração e reconhecimento social. ${ }^{502}$ Neste sentido, os participantes do arrastão, apesar de reificarem a condição de marginalidade do grupo e "naturalizar" a atuação repressiva do Estado, fizeram uso da mesma mídia que os criminaliza para, ainda que inconscientemente, obter visibilidade e denunciar a condição de "proscritos".

\subsection{Neoliberalismo, funk e criminalização da pobreza}

Apesar de haver núcleos de funkeiros com discursos mais politizados, o funk é essencialmente um fenômeno de resistência implícita e é disso que deriva o seu sentido político. Sua contraproposta vem de sua obstinação em pertencer e em manter uma rede hermenêutica que incomoda certos grupos de poder. O funk surge como recurso de interação e de comunicação entre os jovens pobres, que nutrem uma forte desconfiança quanto à política tradicional como meio para a solução de suas expectativas sociais e um sentimento de exclusão, discriminação e revolta.

No Rio de Janeiro, há uma propensão funkeira na Zona Norte e nos subúrbios, frente à opção roqueira na Zona Sul, embora os "negros suburbanos" também gostem de rock e os "brancos do asfalto" da Zona Sul, de funk. ${ }^{503}$ Já no México, o funk chegou como a música da elite mexicana e o rock foi apropriado pelos jovens das colônias populares, o que o introduz em âmbitos proscritos, ainda que as indústrias culturais também tenham encontrado a dimensão "vendável" do rock, que circula de maneira transclassista. Nesse caso, de acordo com Arce,

\footnotetext{
é importante desmitificar os estereótipos que são construídos não tanto contra a música funk, mas contra os elementos de identificação dos pobres. Contra suas redes hermenêuticas. O que nos jovens pobres é quadrilha ou alguma outra caracterização que alude à criminalidade, nos jovens das classes médias e alta é chamado de clube ou grupo de jovens. O que no primeiro grupo é caracterizado por arrastão, no segundo é reunião, encontros, convivência (...) A estigmatização não é construída contra o gênero musical em si mesmo (ainda que o façam alguns dos setores mais reacionários da sociedade), mas contra o grupo social que dele se apropria, o que fica evidente no combate que se realiza contra o funk. A ninguém (salvo às indústrias culturais) importa o gosto ou a preferência que os
}

\footnotetext{
${ }^{502}$ HERSCHMANN, Micael, op. cit. p. 240.

${ }^{503}$ Cf. VIANNA, Hermano. O mundo funk carioca. 2 ed. Rio de Janeiro: Zahar, 1988. p. 32-33.
} 
jovens possam ter pelo rock ou pelo funk, mas sim que este se integre como elemento de identidade de grupos sociais proscritos. ${ }^{504}$

Da mesma forma, Herschmann sugere que, quando parte da sociedade e os órgãos de segurança pública clamam pela interdição dos bailes funk, ou quando se estigmatiza o funkeiro nos meios de comunicação de massa, o que se combate realmente não é o funk, mas o segmento social que o toma como importante forma de expressão social. Segundo o autor, é preciso repensar as representações da violência correlacionando-as à forma como tem sido representada a juventude hoje, especialmente a juventude oriunda dos segmentos menos privilegiados da população. ${ }^{505}$

Não se nega que alguns membros de galeras cometam crimes nem que se identificam com "protetores locais" de facções criminosas. Entretanto, a mídia produz uma imagem monolítica, determinista e reducionista das áreas carentes da cidade, na qual todos os seus moradores aparecem mais ou menos envolvidos com a criminalidade e a violência. $^{506} \mathrm{O}$ funk é focalizado pela mídia como "metáfora de uma cultura desterritorializada, cujo princípio seria ritualizar a própria violência” e o funkeiro, como personagem paradigmático da juventude moradora da favela. Em vez dos diversos estilos de funkeiros, haveria uma marca identitária estigmatizante fortemente vinculada ao crime. $^{507}$

O funk não começou com os "arrastões" nem os conflitos nos bailes. Não são as brigas os fatores determinantes que explicam o rápido destaque alcançado pelo funk ou a construção de um clima de pânico, mas o contexto sociopolítico local e global dos anos $90 .^{508} \mathrm{O}$ fenômeno da fragmentação e pluralização que o funk expressa, é resultado, em parte, da dinâmica do processo de modernização e de globalização desencadeado pelo

\footnotetext{
${ }^{504}$ ARCE, José Manuel Valenzuela, op. cit. p. 99 et seq. "Ao contrário do que se poderia imaginar, à medida que o funk e o hip-hop foram se expandindo e ganhando um novo contorno sociopolítico e econômico, não perderam força como espaço de re-significação dos jovens das periferias e favelas das cidades. Tanto o funk quanto o hip-hop parecem oferecer-se a uma 'negociação`, parecem não exprimir uma identidade cultural particular- apesar de o referencial de cor ser muito importante. Seu princípio estético permite expressar uma experiência cultural heterogênea, a 'negociação de identidades culturais mistas, híbridas ou transicionais"” (HERSCHMANN, Micael, op.cit. p. 220).

${ }^{505}$ HERSCHMANN, Micael, op. cit. p. 50. "De uma hora para outra, o funk passou a ser visto como um dos alicerces de uma 'visão de mundo/ideologia` que vem alimentando o crescimento da violência urbana" (Ibid. p. 100). Cf. DAYRELL, Juarez, op. cit. p. 141-142.

${ }_{506}$ HERSCHMANN, Micael, op. cit. p. 49-50.

${ }^{507}$ CUNHA, Olívia M. G. Conversando com Ice-T: violência e criminalização do funk. In: HERSCHMANN, Micael (Org.). Abalando os anos 90: funk e hip-hop - globalização, violência e estilo cultural. Rio de Janeiro: Rocco, 1997. p. 109.

${ }^{508}$ HERSCHMANN, Micael, op. cit. p. 27.
} 
capitalismo transnacional e, em parte, da impossibilidade de realização das utopias modernas. $^{509}$

A partir das décadas de 80 e 90 do século XX, diante do fim da ameaça comunista e do excesso de força de trabalho, o capital móvel, globalizado e volátil desafiou o movimento operário, consideravelmente enfraquecido. Na empresa pós-moderna, a palavra de ordem é flexibilizar, cortar custos, buscar a mão-de-obra mais barata possível onde quer que ela esteja. Racionalizar significa, desta forma, cortar e não criar empregos. ${ }^{510} \mathrm{~A}$ produtividade na economia globalizada vem sendo obtida exatamente às custas da degradação salarial, da rotatividade no emprego, do aviltamento das relações trabalhistas, da informatização da produção e do subsequente fechamento dos postos convencionais de trabalho. ${ }^{511}$

A crescente informatização das linhas de produção, o avanço da terceirização e o advento de novos modos de inserção no mundo do trabalho fazem com que a mão-de-obra progressivamente se desloque para o setor terciário e para atividades que antes não eram reconhecidas socialmente como empregos $^{512}$, caracterizadas pela flexibilidade e precariedade dos direitos. Grande parte da população foi obrigada a sobreviver de "bicos", trabalhos informais, temporários, não tutelados por direitos trabalhistas, ou recorrer a atividades no limite da ilegalidade. ${ }^{513}$ As duas alternativas colocadas ao proletariado são claras: ou não se trabalha e morre-se de fome ou se trabalha como nunca, em diversos empregos, para ganhar muito pouco.

O Estado de bem-estar social foi a tentativa mais duradoura de conciliar democracia política e economia capitalista. Houve uma espécie de acordo de classes, em que a classe trabalhadora aceitou o modo de produção capitalista contanto que fosse garantido a ela, se necessário por meio da intervenção estatal, um padrão mínimo de vida. ${ }^{514}$ Nos anos 70 e começo dos anos 80, nos EUA e Europa, assistência social e medidas repressivas concorriam para a gestão do excesso de força de trabalho, dividindo, em certa medida, as tarefas. $^{515}$

\footnotetext{
${ }^{509}$ HERSCHMANN, Micael, op. cit. p. 40.

${ }^{510}$ BAUMAN, Zygmunt. O mal-estar da pós-modernidade. Rio de Janeiro: Jorge Zahar, 1997. p. 50.

${ }^{511}$ FARIA José Eduardo. As transformações do direito. Revista brasileira de ciências criminais, São Paulo, n. 22, abr./jun. 1998. p. 239.

${ }_{512}$ DE GIORGI, Alessandro, op. cit. p. 17

${ }^{513}$ BARATTA, Alessandro, op. cit. p. 196.

${ }^{514}$ OFFE, Claus. A democracia partidária competitiva e o welfare state keynesiano: fatores de estabilidade e desorganização. Problemas estruturais do Estado capitalista, Rio de Janeiro, 1984. p. 372.

${ }^{515}$ DE GIORGI, Alessandro, op. cit. p. 51.
} 
Já o Estado neoliberal, sob a justificativa de educar e "livrar" a subclasse negra da dependência, melhorar a eficiência do Estado e reduzir custos, dilapida todas as garantias sociais do Welfare State. A despeito da defesa da necessidade urgente de corte de gastos, benefícios, verbas sociais e descontos fiscais são distribuídos para as camadas privilegiadas da população, agravando ainda mais as desigualdades sociais. Enquanto a intervenção estatal em defesa da parte mais fraca na "lei da selva" é vista como tirania igualitarista, é considerada eficiente e inteligente quando beneficia a parte mais forte.

Por outro lado, na exata proporção em que os gastos sociais do Estado neoliberal vão sendo retirados da educação, saúde e assistência social, são aumentados no setor de segurança, policiamento e presídios. Prender os pobres é eleitoralmente e simbolicamente lucrativo para um Estado desacreditado, devido à insegurança material por ele gerada. Os enormes custos com encarceramento são pouco conhecidos e nunca submetidos a debates públicos, quando não são apresentados com ganhos pelo fato de "reduzirem" o custo do crime. ${ }^{516}$ Se é mais barato excluir e encarcerar os consumidores falhos, isso é preferível ao restabelecimento de seu status de consumidores através de uma política de emprego conjugada com programas de assistência social. ${ }^{517}$

Na medida em que o Estado vai se retirando da economia, deixando à livre iniciativa a regulação da sociedade, observa-se uma intromissão estatal cada vez maior no âmbito punitivo. O Estado neoliberal simplesmente substitui as medidas sociais de combate ao desemprego por medidas penais e a mão invisível do mercado vem acompanhada por uma "luva de ferro". ${ }^{518}$ O direito penal agora cumpre a função de remediar a insegurança material, oriunda da desregulamentação econômica. Observa-se um Estado liberal que não intervêm para mitigar as desigualdades sociais, mas está sempre alerta para reprimir as consequências necessárias e naturais do laissez-faire, laissezpasser. ${ }^{519}$

O desemprego, que corresponde à falta de trabalho assalariado, não é um fatalismo, mas é desencadeado por um problema de organização social. Os desocupados são vítimas da grande contradição entre o desemprego e a ética do trabalho imposta e, consequentemente, sofrem de uma sensação de indignidade e inutilidade. Entretanto, em

\footnotetext{
516 WACQUANT, Loïc. Punir os pobres: a nova gestão da miséria nos Estados Unidos. Rio de Janeiro: Freitas Bastos, 2001. p. 82.

${ }^{517}$ BAUMAN, Zygmunt, op. cit. p. 25.

${ }^{518}$ WACQUANT, Loïc. As prisões da miséria. Rio de Janeiro: Jorge Zahar, 2001. p. 151.

${ }^{519}$ Id. Punir os pobres: a nova gestão da miséria nos Estados Unidos. Rio de Janeiro: Freitas Bastos, 2001. p.
} 21. 
uma sociedade fundada sobre princípios de igualdade durante a vida, quando há desemprego em massa, é mais difícil responsabilizar os próprios desempregados por sua condição e a legitimidade da desigualdade fica enfraquecida. ${ }^{520}$ Neste sentido político, o encarceramento também seria uma forma do Estado reafirmar sua legitimidade e autoridade em face daquela camada da população jovem, ativa, desempregada, teoricamente mais ameaçadora, que demonstra que o sistema capitalista não vai bem. ${ }^{521}$

Para Vera Malaguti, o medo dos anos 1990 aumentou na medida em que entra em cena o projeto neoliberal e seu respectivo Estado penal. O projeto popular agora é a prisão, "criminalizar tudo, todos os sinais exteriores da pobreza". A criminalização do funk aumentou proporcionalmente nesta conjuntura:

O discurso criminalizador é o eixo fundamental de análise das expressões populares hoje. É um momento de muito desemprego, muito desamparo, muita destruição dos laços. O que a gente chama, aqui no capitalismo, de barbárie (...) [Os moradores das favelas são vistos] ou no eixo caridoso-piegas ou no eixo criminalizante-horror. Os dois se complementam. Engraçado que são tratados como 'bandido', 'traficante', 'funkeiro'. Isso é um dispositivo que filtra. Para te dizer 'ele pode ser um bom moço, ele pode fazer um curso de informática, de jardinagem, de palhaço '. Mas não para te dizer 'gente, essa garotada é o máximo, olha só a potência' ou 'se todo mundo só gosta de baile funk, vamos colocá-los no protagonismo? Vamos dar a eles o que eles têm direito? Não. Isso nunca. ${ }^{522}$

\footnotetext{
${ }^{520}$ CHRISTIE, Nils, op. cit. p. 54 et seq.

${ }^{521}$ CHIRICOS, Theodore G.; DELONE, Miriam A., op. cit. p. 424.

${ }^{522}$ Apud MEDEIROS, Janaína, op. cit. p. 21-23.
} 


\section{CONCLUSÃO}

Neste trabalho buscou-se analisar as seguintes questões: houve um processo de criminalização do funk carioca? Contra que setor social ele se voltou? O que e quem o desencadeou? Com quais interesses? Quais fatores o facilitaram? Qual discurso o legitima? Baseado na leitura de legislação, acórdãos, referências bibliográficas que tratam especificamente de funk, racismo, juventude e articulando essas fontes com obras de criminologia, principalmente de teoria crítica, chega-se às seguintes conclusões:

Há, tanto no discurso jornalístico quando no discurso jurídico, uma associação do funk e do baile funk com condutas criminosas, tais como tráfico de drogas, lesão corporal, homicídio, apologia ao crime e corrupção de menores, e com figuras contravencionais referentes à paz pública e à polícia de costumes. Por outro lado, em razão da mídia, dos Poderes Políticos, da Academia e das classes sociais não serem homogêneas, há concomitantemente um discurso que reconhece o funk e o baile funk como manifestações culturais dignas de proteção.

No discurso oficial, não é exatamente o estilo musical ou o estilo de festa que é alvo da repressão, mas as condutas criminosas e contravencionais praticadas em seu contexto. Não se deve tentar justificar a violência das galeras sob eufemismos nem mascarar a opressão e os objetivos primordiais das facções criminosas (lucro econômico) sob a imagem nostálgica e idealizada do bandido justiceiro e protetor. A teoria crítica denuncia, todavia, que essas mesmas práticas criminosas e contravencionais, quando cometidas em outros contextos, por exemplo, em festas frequentadas pela elite econômica e política do país, permanecem impunes. A violência permeia todos os ambientes e todas as classes sociais, mas é a violência praticada pelas classes baixas da população que é vista como ameaçadora.

A violência das galeras funk só passou a ser tratada como um problema quando atingiu as areias da Zona Sul carioca, na véspera de uma eleição municipal em que a candidata favorita era associada aos mesmos setores sociais que frequentavam os bailes funk. A demonização do funk o tornou conhecido para boa parte da juventude de classe média e alta, que passou a frequentar os bailes de comunidade, gerando, num ciclo vicioso, mais apreensão e repressão.

Em alguns bailes funk de fato ocorrem brigas, consumo de drogas e sexo, assim como em vários locais frequentados por uma aglomeração de jovens, mas é mais fácil e 
lucrativo eleitoralmente responsabilizar o funk pelos graves problemas sociais no país e proibir os bailes, seja direta ou indiretamente, através da imposição de inúmeras condições burocráticas para realizá-los de forma lícita, do que enfrentar as causas da violência e da criminalidade.

O funk é ameaçador porque, apesar de ter se popularizado, ainda é identificado com aglomerações de jovens negros, pobres e favelados, um setor visto de forma generalizada e estereotipada como ameaçador em uma sociedade racista e que não fornece estruturalmente os meios para realizarem de forma lícita as metas culturais. O funk é apropriado pelo mercado e reproduz valores da sociedade ampla, como o consumismo. Contudo, ainda que não intencionalmente, questiona outros valores, como a ética do trabalho, o mito da democracia racial e reivindica uma democratização do espaço público.

A distância social entre parte dos "formadores de opinião" e os compositores, cantores e dançarinos de funk fez com que a "música de pobre" fosse considerada "música pobre" e deslegitimada culturalmente. O processo de criminalização é facilitado, por sua vez, na medida em que parte dos frequentadores do baile, por integrar uma subcultura delinquente, internaliza o estereótipo ameaçador, para ganhar status, provocando brigas, arrastões e depredações nos espaços públicos, exaltando facções criminosas nas letras das músicas, cumprindo a profecia auto-realizadora e legitimando a repressão. 


\section{BIBLIOGRAFIA}

ABREU, Carolina de Camargo. Raves: encontros e disputas. Dissertação de Mestrado da FFLCH/USP. São Paulo, 2005.

ALMEIDA, Adjovanes Thadeu Silva de. O olhar da elite sobre a multidão nas reformas urbanas da Primeira República. In: Discursos Sediciosos: crime, direito e sociedade, v. 9/10. Rio de Janeiro: Freitas Bastos, 2000.

ALMEIDA, Maria Isabel Mendes de; TRACY, Kátia Maria de Almeida. Noites nômades: espaço e subjetividade nas culturas jovens contemporâneas. Rio de Janeiro: Rocco, 2003.

ALVITO, Marcos. As cores de Acari: uma favela carioca. Rio de Janeiro: Editora FGV, 2001.

ARCE, José Manuel Valenzuela. Vida de barro duro: cultura popular juvenil e grafite. Rio de Janeiro: Editora UFRJ, 1999.

BARATTA, Alessandro. Criminologia crítica e crítica do Direito Penal: introdução à sociologia do direito penal. Rio de Janeiro: Revan, 1997.

BATISTA, Nilo. Punidos e mal pagos: violência, justiça, segurança pública e direitos humanos no Brasil de hoje. Rio de Janeiro: Revan, 1990.

BATISTA, Vera Malaguti. Intolerância dez, ou a propaganda é a alma do negócio. In: Discursos sediciosos: crime, direito e sociedade, v. 2, n. 4. Rio de Janeiro: Revan, 1997.

. A arquitetura do medo. In: Discursos Sediciosos: crime, direito e sociedade, ano 7, n. 12, 2002.

. O medo na cidade do Rio de Janeiro: dois tempos de uma história. Rio de Janeiro: Revan, 2003.

; BATISTA, Carlos Bruce; BORGES, Rafael C. Entrevista com Mr. Catra. In: Discursos sediciosos: crime, direito e sociedade, $\mathrm{n}^{\circ}$ 15/16. Rio de Janeiro: Revan, 2007.

BAUMAN, Zygmunt. O mal-estar da pós-modernidade. Rio de Janeiro: Jorge Zahar, 1997.

Zahar, 1999.

Globalização: as consequências humanas. Rio de Janeiro: Jorge

BECKER, Howard. Outsiders: estudos de sociologia do desvio. Rio de Janeiro: Zahar, 2009.

BELLI, Benoni. Tolerância Zero e democracia no Brasil: visões da segurança pública na década de 90. São Paulo: Perspectiva, 2004. 
BEZERRA, Arthur Coelho. Apontamentos sobre o consumo de funk carioca pelas elites urbanas. XIII Congresso Brasileiro de Sociologia. 2007, UFPE. Disponível em: $<$ http://www.sbsociologia.com.br/congresso_v02/papers/GT4\%20Consumo,\%20Sociedade $\%$

20e\%20A\%C3\%A7\%C3\%A3o\%20Coletiva/Microsoft\%20Word\%20-

$\% 20$ texto\%20pra\%20SBS\%202.pdf>. Acesso em: 01 nov. 2008.

BITENCOURT, Cezar Roberto. Falência da pena de prisão: causas e alternativas. 2 ed. São Paulo: Saraiva, 2001.

BORGES, Ana Luiza Mendes; AZEVEDO, Clara de Assunção. A mancha de lazer na Vila Olímpia. In: MAGNANI, José Guilherme Cantor; MANTESE, Bruna (Org.). Jovens na Metrópole: etnografias de lazer, encontro e sociabilidade. São Paulo: Editora Terceiro Nome, 2007.

BRINTON, Crane. Anatomia das revoluções. Rio de Janeiro: Fundo de Cultura, 1958.

CALDEIRA, Teresa. Cidade de Muros: crime, segregação e cidadania em São Paulo. São Paulo: Editora 34/Edusp, 2000.

CARMO, Paulo Sérgio do. Culturas da rebeldia: a juventude em questão. São Paulo: Editora SENAC, 2001.

CARRANO, Paulo César Rodrigues. Os jovens e a cidade: identidades e práticas culturais em Angra de tantos reis e rainhas. Rio de Janeiro: Relume Dumará, 2002.

CECCHETTO, Fátima. As galeras funk cariocas: entre o lúdico e o violento. In: VIANNA, Hermano (Org.). Galeras cariocas: territórios de conflitos e encontros culturais. Rio de Janeiro: Editora da UFRJ, 1997.

; FARIAS, Patrícia. Do funk bandido ao pornofunk: o vaivém da sociabilidade juvenil carioca. In: Interseções: Revista de Estudos Interdisciplinares, ano 4, número 2. Rio de Janeiro: PPGCS/UERJ, 2002.

CHALHOUB, Sidney. Medo branco de almas negras: escravos libertos e republicanos na cidade do Rio. In: Discursos Sediciosos: crime, direito e sociedade, ano $1, \mathrm{n}^{\circ} 1$. Rio de Janeiro: Relume Dumará, 1996.

CHIRICOS, Theodore G.; DELONE, Miriam A. Labor surplus and punishment: a review and assessment of theory and evidence. Criminology, vol. 29,14, 1991.

CHRISTIE, Nils. A indústria do controle do crime. Rio de Janeiro: Forense, 1998.

COHEN, Albert K. Delinquent boys: the culture of the gang. Illinois: The Free Press, 1955.

CUNHA, Olívia M. G. Cinco vezes favela- um reflexão. In: ALVITO, Marcos; VELHO, Gilberto (Org.). Cidadania e Violência. Rio de Janeiro: UFRJ e FGV, 1996. 
Conversando com Ice-T: violência e criminalização do funk. In: HERSCHMANN, Micael (Org.). Abalando os anos 90: funk e hip-hop - globalização, violência e estilo cultural. Rio de Janeiro: Rocco, 1997.

Bonde do mal. In: MAGGIE, Yvonne; REZENDE, Cláudia B. (Org). Raça como retórica: a construção da diferença. Rio de Janeiro: Civilização Brasileira, 2001.

CYMROT, Danilo. Crimes contra o patrimônio arqueológico no ordenamento jurídico brasileiro. In: CARVALHO, Aline Vieira de; SOARES, Inês Virgínia Prado; FUNARI, Pedro Paulo A.; SILVA, Sérgio Francisco Serafim Monteiro da (Org.). Arqueologia, direito e democracia. Erechim: Habilis, 2009.

DAYRELL, Juarez. A música entra em cena: o rap e o funk na socialização da juventude. Belo Horizonte: Editora UFMG, 2005.

DE GIORGI, Alessandro. A miséria governada através do sistema penal. Rio de Janeiro: Revan, 2006.

DEBATE 7 - Organizações comunitárias, cultura popular e violência II. In: ALVITO, Marcos; VELHO, Gilberto. Cidadania e Violência. Rio de Janeiro: UFRJ e FGV, 1996.

DELEUZE, Gilles. Conversações, 1972-1990. Rio de Janeiro: Editora 34, 1992.

DELUMEAU, Jean. História do medo no Ocidente. 4. ed. São Paulo: Companhia das Letras, 1999.

DIAS, Jorge Figueiredo; ANDRADE, Manuel da Costa. Criminologia: o homem delinquente e a sociedade criminógena. Coimbra: Editora Coimbra, 1992.

DIÓGENES, Glória. Rebeldia urbana: tramas de exclusão e violência juvenil. In: HERSCHMANN, Micael (Org.). Abalando os anos 90: funk e hip-hop - globalização, violência e estilo cultural. Rio de Janeiro: Rocco, 1997.

- Gangues e polícia: campos de enfrentamento e estratégias de diferenciação. In: PEREIRA, Carlos Alberto Messeder; RONDELLI, Elizabeth; SCHOLLHAMMER, Karl Erik; HERSCHMANN, Micael (Org.). Linguagens da violência. Rio de Janeiro: Rocco, 2000.

DUARTE, Luís Miguel. A boca do diabo: a blasfêmia e o direito penal português da Baixa Idade Média. In: Lusitania Sacra. $2^{a}$ série, 4. Lisboa: Porto, 1992.

DUMANS, Alexandre Moura; BATISTA, Vera Malaguti. Nada de novo no front. In: Revista Ciência Hoje, São Paulo, n. 181, abril 2002.

DURKHEIM, Émile. Da divisão do trabalho social. São Paulo: Martins Fontes, 1995.

ELBERT, Carlos Alberto. La criminologia del siglo XXI em América Latina. Buenos Aires: Rubinzal-Culzoni, 1999. 
ESSINGER, Silvio. Batidão: uma história do funk. Rio de Janeiro: Record, 2005.

FAOUR, Rodrigo. História sexual da MPB: a evolução do amor e do sexo na canção brasileira. Rio de Janeiro: Record, 2006.

FARIA José Eduardo. As transformações do direito. Revista brasileira de ciências criminais, São Paulo, n. 22, abr./jun. 1998.

FAUSTO, Boris. Crime e cotidiano: a criminalidade em São Paulo (1880-1924). 2. ed. São Paulo: EDUSP, 2001.

FEELEY, Malcolm; SIMON, Jonathan. The new penology: notes on the emerging strategy of corrections and its implicatios. In: Criminology 30-4, novembro de 1992. Disponível em: $<$ http://heinonline.org/HOL/PDF?handle=hein.journals/crim30\&id=463\&print=section \&section=33\&ext=pdf $>$. Acesso em: 09 mar. 2010.

FOUCAULT, Michel. A verdade e as formas jurídicas. Rio de Janeiro: Nau, 1996. . Vigiar e punir. 28 ed. Petrópolis: Editora Vozes, 2004. . Microfísica do poder. 20 ed. Rio de Janeiro: Graal, 2004.

FRÚGOLI, Heitor. Centralidade em São Paulo. São Paulo: Editora Cortez/Edusp, 2000.

GARLAND, David. Punishment and modern society: a study in social theory. Chicago: Oxford University Press, 1993.

GOFFMAN, Ervin. Manicômios, prisões e conventos. São Paulo: Perspectiva, 1996.

GOMES, Luiz Flávio; GARCÍA-PABLOS DE MOLINA, Antonio. Criminologia. 3. ed. São Paulo: RT, 2000.

São Paulo: RT, 2010. Criminologia. 7. ed.

GUEDES, Maurício da Silva. A música que toca é nós que manda: um estudo do proibidão. 2007. Dissertação (Mestrado)-Departamento de Psicologia, Pontifícia Universidade Católica, Rio de Janeiro, 2007. Disponível em: http://www.maxwell.lambda.ele.puc-rio.br/cgibin/db2www/PRG_0991.D2W/SHOW?Cont=9975:pt\&Mat=\&Sys=\&Nr=\&Fun $=\& C d L i n P$ rg=pt. Acesso em: 01 set. 2008.

GUIMARÃES, Eloísa. Escola, Galeras e Narcotráfico. Rio de Janeiro: Editora UFRJ, 2003 .

HERSCHMANN, Micael. O funk e o hip hop invadem a cena. Rio de Janeiro: Editora UFRJ, 2000. 
HOBSBAWM, Eric. Bandidos. Rio de Janeiro: Forense-Universitária, 1976.

KARAM, Maria Lúcia. Drogas ilícitas e globalização. The Narco News Bulletin, n. 30, maio 2003. Disponível em: http://www.narconews.com/Issue30/artigo785.html. Acesso em: 14 janeiro 2011.

KHEL, Maria Rita. As asas quebradas. Folha de S. Paulo, São Paulo, 26 março 2006. Caderno Mais.

KOERNER, Andrei. O impossível "panóptico tropical-escravista": práticas prisionais, política e sociedade no Brasil do século XIX. In: Revista Brasileira de Ciências Criminais, $\mathrm{n}^{\mathrm{o}} 35$, jul/set 2001.

LEAL, Luiz Augusto Pinheiro. Vozerias, assuadas e capoeira em Belém (1848-1850). In: Discursos sediciosos: crime, direito e sociedade, ano 4, n. 7/8. Rio de Janeiro: Instituto Carioca de Criminologia, 1999.

MACEDO, Suzana. DJ Marlboro na terra do funk- Bailes, bondes, galeras e MCs. Rio de Janeiro: Dantes Livraria e Editora, 2003.

MAGNANI, José Guilherme Cantor. De perto e de dentro: notas para uma antropologia urbana. In: $R B C S$, vol. 17 , n. 49, junho 2002.

MARTINS, Denis. Direito e cultura popular: o batidão do funk carioca no ordenamento jurídico. 2006. 130 fl. Monografia-Faculdade de Direito, UERJ, Rio de Janeiro, 2006. Disponível em: http://www.overmundo.com.br/banco/direito-e-cultura-popular-o-batidaodo-funk-carioca-no-ordenamento-juridico. Acesso em: 01 set. 2008.

MATTOS, Carla dos Santos. No ritmo neurótico: cultura funk e performances "proibidas" em contexto de violência no Rio de Janeiro. 2006. 155f. Dissertação (Mestrado)-Instituto de Filosofia e Ciências Sociais, UERJ, Rio de Janeiro, 2006. Disponível em: http://www.bdtd.uerj.br/tde_busca/arquivo.php?codArquivo=91. Acesso em: 01 set. 2008.

MEDEIROS, Janaína. Funk carioca: crime ou cultura?: o som dá medo: e prazer. São Paulo: Editora Terceiro Nome, 2006.

MELOSSI, Dario; PAVARINI, Massimo. Cárcere e fábrica. Rio de Janeiro: Revan/Instituto Carioca de Criminologia, 2002.

MENDONÇA, Kleber. A onda do arrastão. In: Discursos Sediciosos: crime, direito e sociedade, ano 4, no 7-8. Rio de Janeiro: Freitas Bastos/Instituto Carioca de Criminologia, $1^{\circ}$ e $2^{\circ}$ semestres de 1999 .

MINAYO, Maria Cecília de Souza et alii. Fala, galera: juventude, violência e cidadania no Rio de Janeiro. Rio de Janeiro: Garamond, 1999.

MORETZSOHN, Sylvia. O caso Tim Lopes: o mito da "mídia cidadã". In: Discursos Sediciosos: crime, direito e sociedade, vol. 12. Rio de Janeiro: Editora Revan, 2002. 
De Carcavelos ao Leblon: arrastões do preconceito. In: Discursos Sediciosos: crime, direito e sociedade, $\mathrm{n}^{\circ}$ 15-16. Rio de Janeiro: Freitas Bastos/Instituto Carioca de Criminologia, 2007.

MURAD, Maurício. Futebol e violência no Brasil. In: Discursos Sediciosos, ano 1, $\mathrm{n}^{\circ} 1$. Rio de Janeiro: Editora Relume-Dumará, 1996.

NETO, Ana Maria Q. Fausto; QUIROGA, Consuelo. Juventude urbana pobre: manifestações públicas e leituras sociais. In: PEREIRA, Carlos Alberto Messeder; RONDELLI, Elizabeth; SCHOLLHAMMER, Karl Erik; HERSCHMANN, Micael (Org.). Linguagens da violência. Rio de Janeiro: Rocco, 2000.

OFFE, Claus. A democracia partidária competitiva e o welfare state keynesiano: fatores de estabilidade e desorganização. Problemas estruturais do Estado capitalista, Rio de Janeiro, 1984.

PEREGRINO, Mônica. "E o bonde abalou! Contenção, juventude e embate nas escolas do Rio". In: FRAGA, Paulo César Pontes; LULIANELLI, Jorge Atílio da Silva (Org.). Jovens em tempo real. Rio de Janeiro: DP\&A, 2003.

PEREIRA, Alexandre Barbosa. De rolê pela cidade: os pixadores em São Paulo. 2005. Dissertação (Mestrado)-Faculdade de Filosofia, Letras e Ciências Humanas, Universidade de São Paulo, São Paulo, 2005.

PIVA, Luiz Guilherme. A economia do crime. Revista Consultor Jurídico, São Paulo, 24 de maio de 2006. Disponível em: http://www.conjur.com.br/2006-mai24/crime_organizado_nao_fica_dever_mundo_negocios. Acesso em: 14 janeiro. 2011.

QUEIROZ, Tereza Correia da N. Culturas juvenis, contestação social e cidadania: a voz ativa do hip hop. In: ALVIM, Rosilene; JUNIOR, Edísio Ferreira; QUEIROZ, Tereza (Org.). (Re)construções da juventude: cultura e representações contemporâneas. João Pessoa: Editora Universitária-PPGS/UFPB, 2004.

RESENDE, Juliana. Operação Rio. São Paulo: Editora Página Aberta, 1995.

RIBEIRO, Manoel. Funk'n Rio: vilão ou big business? In: Revista do Patrimônio Histórico e Artístico Nacional, n. 24. Ministério da Cultura, IPHAN, 1996.

RODRIGUES, Luciana Boiteux de Figueiredo. Controle penal sobre as drogas ilícitas: o impacto do proibicionismo no sistema penal e na sociedade. 2006. Tese (Doutorado)Departamento de Direito Penal, Medicina Forense e Criminologia, Universidade de São Paulo, São Paulo, 2006.

RODRIGUES, Raimundo Nina. As raças humanas e a responsabilidade penal no Brazil. Rio de Janeiro: Guanabara, 1894.

RUSCHE, Georg; KIRSCHHEIMER, Otto. Punição e estrutura social. 2.ed. Rio de Janeiro: Revan/Instituto Carioca de Criminologia, 2004. 
RUSSANO, Rodrigo. "Bota o fuzil pra cantar": o funk proibido no Rio de Janeiro. 2006. 124 f. Dissertação (Mestrado)- Centro de Letras e Artes, UNIRIO, Rio de Janeiro, 2006. Disponível em: www.cipedya.com/web/FileDownload.aspx?IDFile=158580. Acesso em: 01 set. 2008.

SALLES, Ecio P de. O bom e o feio: funk proibidão, sociabilidade e a produção do comum. In: $Z$ Ensaios, ano III, $\mathrm{n}^{\mathrm{o}}$ 3, ago/nov 2007. Disponível em: http://www.pacc.ufrj.br/z/ano3/03/ecio.htm. Acesso em: 01 set. 2008.

SALLES, Lúcia (Org.). DJ Marlboro: o funk no Brasil - por ele mesmo. Rio de Janeiro: Mauad, 1996.

SANSONE, Livio. Funk baiano: uma versão local de um fenômeno global? In: HERSCHMANN, Micael (Org.). Abalando os anos 90: funk e hip hop: globalização, violência e estilo cultural. Rio de Janeiro: Rocco, 1997.

SHECAIRA, Sérgio Salomão. Importância e atualidade da Escola de Chicago. In: Discursos Sediciosos: crime, direito e sociedade, v. 9/10. Rio de Janeiro: Freitas Bastos, 2000.

Criminologia. São Paulo: Revista dos Tribunais, 2004.

Cidadania.n. 5, v. 2, 2009.

. Tolerância Zero. In: Revista Internacional de Direito e

SILVA, Bezerra da. Discursos sediciosos entrevista Bezerra da Silva. In: Discursos sediciosos: crime, direito e sociedade, ano 4, n. 7/8. Rio de Janeiro: Instituto Carioca de Criminologia, 1999.

SILVA, Rejane Valvano Corrêa da; COUCEIRO, Luiz Alberto. "Pega o bandido corno!": práticas e representações de crime e violência num bairro da zona sul do Rio de Janeiro. In: Discursos Sediciosos: crime, direito e sociedade, $\mathrm{n}^{\circ}$ 15-16. Rio de Janeiro: Freitas Bastos/Instituto Carioca de Criminologia, $1^{\circ}$ e $2^{\circ}$ semestres de 2007.

SILVA, Suylan Midlej e. O lúdico e o étnico no funk do "Black Bahia". In: SANSONE, Livio; SANTOS, Jocélio Teles dos (Org.). Ritmo em trânsito: sócio-antropologia da música baiana. Salvador: Dynamis Editorial, 1997.

SILVA JR., Hédio. Direito Penal em preto e branco. In: Revista Brasileira de Ciências Criminais, ano 7, n. 27, jul/set 1999.

SOUTO, Jane. Os outros lados do funk carioca. In: VIANNA, Hermano (Org.). Galeras cariocas: territórios de conflitos e encontros culturais. Rio de Janeiro: Editora da UFRJ, 1997.

VENTURA, Zuenir. Cidade partida. Rio de Janeiro: Companhia das Letras, 1994.

VIANNA, Hermano. O mundo funk carioca. 2 ed. Rio de Janeiro: Zahar, 1988. 
O funk como símbolo da violência carioca. In: VELHO, Gilberto; ALVITO, Marcos. Cidadania e violência. Rio de Janeiro: UFRJ/FGV, 1996.

VIANNA, Letícia C. R. Bezerra da Silva: produto do morro: trajetória e obra de um sambista que não é santo. Rio de Janeiro: Jorge Zahar, 1998.

VIEIRA, Thiago Braga. Proibidão de boca em boca: gritos silenciosos de uma memória subterrânea: $\mathrm{O}$ funk proibido como fonte para o estudo da violência armada organizada no Rio de Janeiro (1994-2002). 2009. Monografia-Centro de Filosofia e Ciências Humanas, Universidade Federal do Rio de Janeiro, Rio de Janeiro, 2009.

WACQUANT, Loïc. A globalização da "Tolerância Zero". In: Discursos Sediciosos: crime, direito e sociedade, v. 9/10. Rio de Janeiro: Freitas Bastos, 2000.

. As prisões da miséria. Rio de Janeiro: Jorge Zahar, 2001.

Punir os pobres: a nova gestão da miséria nos Estados Unidos. Rio de Janeiro: Freitas Bastos, 2001.

WEBER, Max. A ética protestante e o espírito do capitalismo. São Paulo: Companhia das Letras, 2004.

WIEVIORKA, Michel. O novo paradigma da violência. In: Tempo Social, vol. 9, n. 1. São Paulo, maio de 1997.

XAVIER, Ismail. Da violência justiceira à violência ressentida. In: Revista Ilha do Desterro, $\mathrm{n}^{\mathrm{o}}$ 51. Florianópolis, jul/dez 2006. Disponível em: $<$ http://www.periodicos.ufsc.br/index.php/desterro/article/viewFile/9777/9009>. Acesso em: 05 mai. 2010.

YOUNG, Jock. A sociedade excludente: exclusão social, criminalidade e diferença da modernidade recente. Rio de Janeiro: Revan, 2002.

YÚDICE, George. A funkificação do Rio. In: HERSCHMANN, Michael (Org.). Abalando os anos 90: funk e hip-hop - globalização, violência e estilo cultural. Rio de Janeiro: Rocco, 1997.

ZAFFARONI, Eugênio Raúl; BATISTA, Nilo; ALAGIA, Alejandro; SLOKAR, Alejandro. Direito Penal brasileiro: primeiro volume-Teoria Geral do Direito Penal. 3 ed. Rio de Janeiro: Revan, 2006

ZALUAR, Alba. A máquina e a revolta: as organizações populares e o significado da pobreza. São Paulo: Editora Brasiliense, 1985.

. O condomínio do diabo. Rio de Janeiro: Editora Revan/UFRJ, 1994.

- Gangues, Galeras e Quadrilhas: globalização, juventude e violência. In: VIANNA, Hermano (Org.). Galeras cariocas: territórios de conflitos e encontros culturais. Rio de Janeiro: Editora da UFRJ, 1997. 